Matthew J. Gray

V. Gregory Chinchar

Editors

Ranaviruses

Lethal Pathogens of

Ectothermic Vertebrates

Springer Open 
Ranaviruses 

Matthew J. Gray • V. Gregory Chinchar Editors

\section{Ranaviruses}

Lethal Pathogens of Ectothermic Vertebrates

黛 Springer Open 


\section{Editors}

Matthew J. Gray

Center for Wildlife Health

Department of Forest, Wildlife, and Fisheries

University of Tennessee

Knoxville, TN, USA

\author{
V. Gregory Chinchar \\ Department of Microbiology \\ University of Mississippi Medical Center \\ Jackson, MS, USA
}

ISBN 978-3-319-13754-4

ISBN 978-3-319-13755-1 (eBook)

DOI 10.1007/978-3-319-13755-1

Library of Congress Control Number: 2015935731

Springer Cham Heidelberg New York Dordrecht London

(C) The Editor(s) (if applicable) and the Author(s) 2015. The book is published with open access at SpringerLink.com

Open Access This book is distributed under the terms of the Creative Commons Attribution Noncommercial License, which permits any noncommercial use, distribution, and reproduction in any medium, provided the original author(s) and source are credited.

All commercial rights are reserved by the Publisher, whether the whole or part of the material is concerned, specifically the rights of translation, reprinting, reuse of illustrations, recitation, broadcasting, reproduction on microfilms or in any other physical way, and transmission or information storage and retrieval, electronic adaptation, computer software, or by similar or dissimilar methodology now known or hereafter developed.

The use of general descriptive names, registered names, trademarks, service marks, etc. in this publication does not imply, even in the absence of a specific statement, that such names are exempt from the relevant protective laws and regulations and therefore free for general use.

The publisher, the authors and the editors are safe to assume that the advice and information in this book are believed to be true and accurate at the date of publication. Neither the publisher nor the authors or the editors give a warranty, express or implied, with respect to the material contained herein or for any errors or omissions that may have been made.

Printed on acid-free paper

Springer International Publishing AG Switzerland is part of Springer Science+Business Media (www.springer.com) 

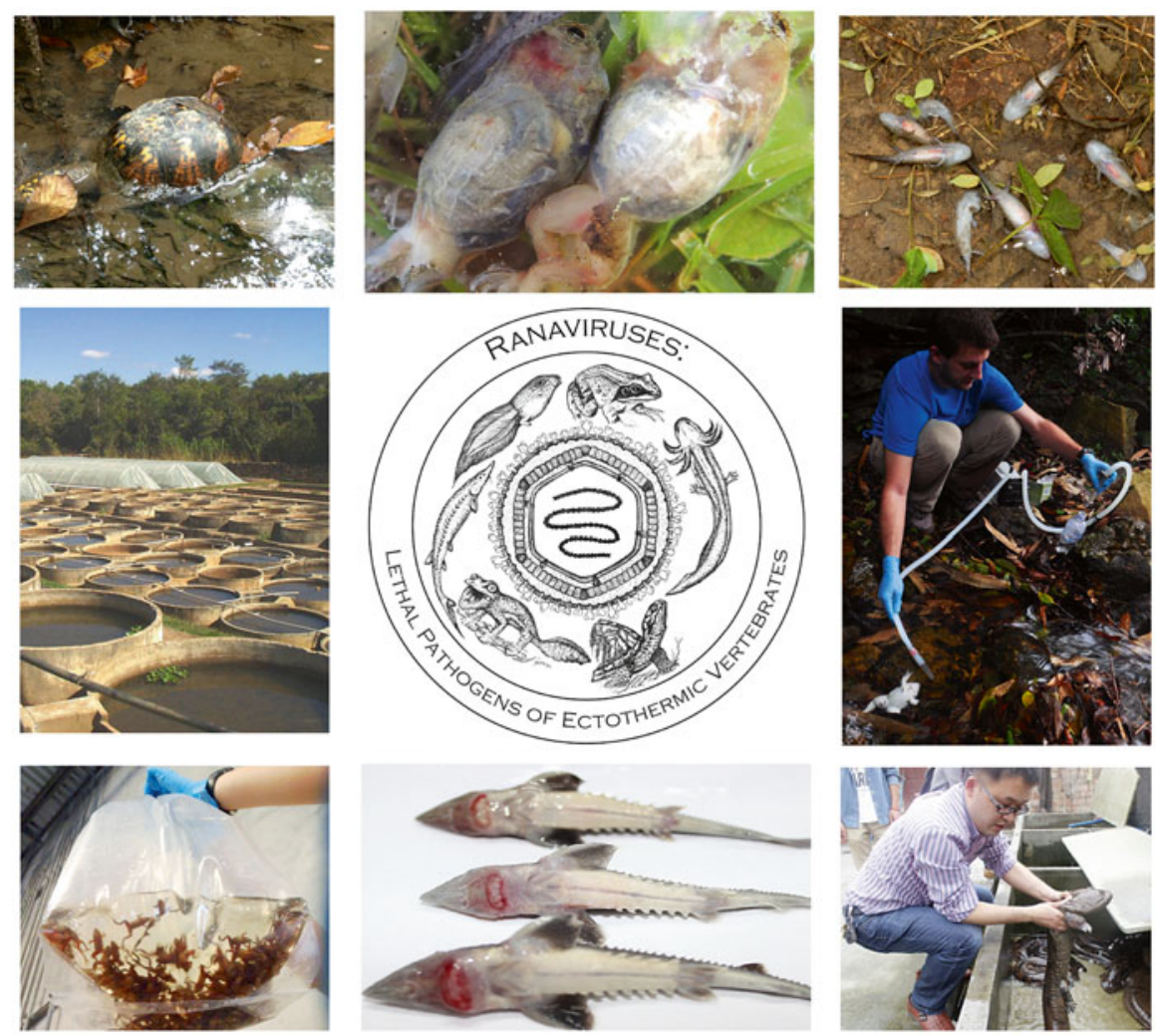

Ranaviruses are a group of emerging pathogens responsible for mass die-offs of amphibians, fish, and reptiles in captive and wild populations across the globe. Global commerce of ectothermic vertebrate species and stressors may be contributing to emergence of these pathogens. Photo credits (clockwise from top left): Matthew Allender, Nathaniel Wheelwright, Matthew Neimiller, Jonathan Kolby, Yi Geng, Yi Geng, Jonathan Kolby, and Rolando Mazzoni. Artwork by Jeanne Jones. 



\section{Contents}

Introduction: History and Future of Ranaviruses ....................................... Matthew J. Gray and V. Gregory Chinchar

Distribution and Host Range of Ranaviruses

Amanda L.J. Duffus, Thomas B. Waltzek, Anke C. Stöhr, Matthew C. Allender, Michael Gotesman, Richard J. Whittington, Paul Hick, Megan K. Hines, and Rachel E. Marschang

Ranavirus Taxonomy and Phylogeny.

James K. Jancovich, Natalie K. Steckler, and Thomas B. Waltzek

Ranavirus Ecology and Evolution: from Epidemiology to Extinction........ 71 Jesse L. Brunner, Andrew Storfer, Matthew J. Gray, and Jason T. Hoverman

Ranavirus Replication: Molecular, Cellular, and Immunological Events.

James K. Jancovich, Qiwei Qin, Qi-Ya Zhang, and V. Gregory Chinchar

Ranavirus Host Immunity and Immune Evasion

Leon Grayfer, Eva-Stina Edholm, Francisco De Jesús Andino,

V. Gregory Chinchar, and Jacques Robert

Comparative Pathology of Ranaviruses and Diagnostic Techniques

Debra L. Miller, Allan P. Pessier, Paul Hick, and Richard J. Whittington

Design and Analysis of Ranavirus Studies: Surveillance and Assessing Risk

Matthew J. Gray, Jesse L. Brunner, Julia E. Earl, and Ellen Ariel

Index 



\section{Contributors}

Matthew C. Allender Department of Comparative Biosciences, College of Veterinary Medicine, University of Illinois, Urbana, IL, USA

Francisco De Jesús Andino Department of Microbiology and Immunology, University of Rochester Medical Center, Rochester, NY, USA

Ellen Ariel College of Public Health, Medical and Veterinary Sciences, James Cook University, Townsville, QLD, Australia

Jesse L. Brunner School of Biological Sciences, Washington State University, Pullman, WA, USA

V. Gregory Chinchar Department of Microbiology, University of Mississippi Medical Center, Jackson, MS, USA

Amanda L.J. Duffus Department of Biology, Gordon State College, Barnesville, GA, USA

Julia E. Earl National Institute for Mathematical and Biological Synthesis, University of Tennessee, Knoxville, TN, USA

Eva-Stina Edholm Department of Microbiology and Immunology, University of Rochester Medical Center, Rochester, NY, USA

Michael Gotesman Department of Infectious Diseases and Pathology, College of Veterinary Medicine, University of Florida, Gainesville, FL, USA

Matthew J. Gray Center for Wildlife Health, Department of Forestry, Wildlife and Fisheries, University of Tennessee, Knoxville, TN, USA

Leon Grayfer Department of Microbiology and Immunology, University of Rochester Medical Center, Rochester, NY, USA

Paul Hick Faculty of Veterinary Science, University of Sydney, Sydney, NSW, Australia 
Megan K. Hines University of Wisconsin-Madison, School of Veterinary Medicine, Madison, WI, USA

Jason T. Hoverman Department of Forestry and Natural Resources, Purdue University, West Lafayette, IN, USA

James K. Jancovich Department of Biological Sciences, California State University, San Marcos, CA, USA

Rachel E. Marschang Laboklin GmbH \& Co. KG, Bad Kissingen, Germany

Debra L. Miller Center for Wildlife Health and Department of Biomedical and Diagnostic Sciences, University of Tennessee, Knoxville, TN, USA

Allan P. Pessier Institution for Conservation Research, San Diego Zoo, San Diego, CA, USA

Qiwei Qin Key Laboratory of Tropical Marine Bio-Resources and Ecology, South China Sea Institute of Oceanology, Chinese Academy of Sciences, Guangzhou, China

Jacques Robert Department of Microbiology and Immunology, University of Rochester Medical Center, Rochester, NY, USA

Natalie K. Steckler Department of Infectious Diseases and Pathology, College of Veterinary Medicine, University of Florida, Gainesville, FL, USA

Anke C. Stöhr Institute of Environmental and Animal Hygiene, University of Hohenheim, Stuttgart, Germany

Andrew Storfer School of Biological Sciences, Washington State University, Pullman, WA, USA

Thomas B. Waltzek Department of Infectious Diseases and Pathology, College of Veterinary Medicine, University of Florida, Gainesville, FL, USA

Richard J. Whittington Faculty of Veterinary Science, University of Sydney, Sydney, NSW, Australia

Qi-Ya Zhang State Key Laboratory of Freshwater Ecology and Biotechnology, Institute of Hydrobiology, Chinese Academy of Sciences, Wuhan, Hubei, China 


\title{
Introduction: History and Future of Ranaviruses
}

\author{
Matthew J. Gray and V. Gregory Chinchar
}

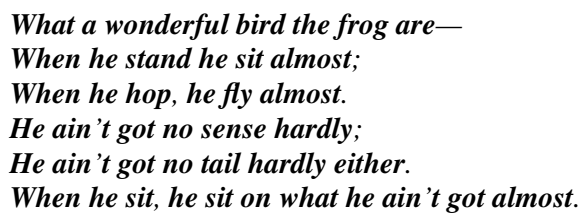

Anonymous

Allan Granoff (1923-2012) serendipitously isolated the first ranaviruses (Granoff et al. 1966) while attempting to generate cell lines that would support the replication of Lucke herpesvirus. Although one of Allan's isolates, Frog virus 3 (FV3), subsequently became the best-characterized member of both the genus (Ranavirus) and the family (Iridoviridae); the impact of that discovery was not fully appreciated at the time. FV3 was neither the first iridovirus to be recognized as a pathogen of lower vertebrates or the first isolated. Those honors belonged to lymphocystis disease virus (LCDV) and invertebrate iridovirus 1 (IIV1), respectively (Wissenberg 1965; Xeros 1954). LCDV is responsible for a generally non-life threatening, but disfiguring, disease in fish characterized by the appearance of wartlike growths on the skin and (rarely) internal organs, whereas IIV1 is the causative agent of latent and patent infections in crane fly larvae. Despite its lack of primacy, FV3 was studied because, in keeping with the mission of St. Jude Hospital, it was initially thought to be linked to adenocarcinoma in frogs and thus could be a useful model of human malignancies. Furthermore, unlike LCDV and IIV1, it could be readily grown in cultured cells and was thus amenable to detailed molecular characterization. Although its role in tumor development was soon proven incorrect, FV3 served as a gateway into understanding the replication strategy of a heretofore poorly studied virus family. Moreover, over the next 20 years, its study led to

\footnotetext{
M.J. Gray $(\bowtie)$

Center for Wildlife Health, Department of Forestry, Wildlife and Fisheries, University of Tennessee, 274 Ellington Plant Sciences Building, Knoxville, TN 37996-4563, USA

e-mail: mgray11@utk.edu

V.G. Chinchar

Department of Microbiology, University of Mississippi Medical Center,

Jackson, MS 39216, USA
} 
important insights not only into iridovirus replication, but also eukaryotic biology, virus evolution, and host-virus interactions.

Elucidating the molecular and cellular events of FV3 replication occupied Allan, his co-workers, and others in the USA and Europe from the discovery of FV3 in 1965 until the early 1990s (Murti et al. 1985; Williams 1996). However, despite the molecular insights gained in these studies, investigations of FV3 and other members of the family languished for a variety of reasons. After some initial optimism, it was clear that invertebrate iridoviruses were not suitable, as was baculovirus, as an insect biocontrol agent. Furthermore, FV3 and related vertebrate iridoviruses were initially viewed as minor pathogens, because few outbreaks of ranaviral disease were reported, and those that were, appeared to have minor effects on populations. In addition, unlike LCDV, there was little evidence of infection among ecologically or commercially important fish species. Therefore, even before the recent emphasis on "translational research," iridovirus studies took a backseat to more medically and commercially relevant poxviruses and herpesviruses.

However, beginning in the mid-1980s and continuing to the present, this sanguine view of ranaviruses slowly changed, as an increasingly large number of isolates similar to, but not necessarily identical with, FV3 were linked to die-offs of fish, reptiles, and amphibians (frogs, toads, and salamanders) of both ecological and commercial importance (Chinchar et al. 2009). To date, cases of ranavirus infection and disease have been documented on six continents and in at least 175 species of ectothermic vertebrates (Duffus et al. 2015). It is unclear whether the global emergence of ranaviruses is a reflection of their increased virulence or dissemination (via natural or human-related activities) or increased surveillance coupled with better diagnostic and detection mechanisms. Regardless of the reasons, ranaviruses are now viewed as pathogenic agents capable of infecting all classes of ectothermic vertebrates (fish, reptiles, and amphibians) and, depending upon the specific virus, host, and environmental factors, triggering significant morbidity and mortality.

The family Iridoviridae currently contains five genera, two of which infect invertebrates (Iridovirus and Chloriridovirus) and three that infect only ectothermic vertebrates (Lymphocystivirus, Megalocytivirus, and Ranavirus; Jancovich et al. 2015a). Lymphocystiviruses and megalocytiviruses only infect fish, whereas, as indicated above, ranaviruses target fish, amphibians, and reptiles. Infection of "higher" vertebrates (i.e., birds and mammals) has not been reported. However, this block likely reflects a temperature limit above which the virus cannot replicate (approximately $32{ }^{\circ} \mathrm{C}$ ), and not a lack of suitable cellular receptors, as ranaviruses can replicate in mammalian cell lines (e.g., baby hamster kidney) when incubated at $30{ }^{\circ} \mathrm{C}$. Ranaviruses also cause apoptotic cell death in mammals even if the pathogen has been inactivated by heat or radiation (Grayfer et al. 2015). Thus, ranaviruses represent a group of pathogens that possesses a wide host range and the potential to affect diverse populations of vertebrate species around the globe.

The question frequently arises, "Are ranaviruses a significant threat to wildlife?" We believe the answer is, "Yes," but that the seriousness of the threat is dependent 
upon a number of factors. Brunner et al. (2015) describe how ranaviruses could contribute to species declines using epidemiological theory and results from mathematical simulations. However, because there have been very few long-term longitudinal studies on populations with reoccurring ranavirus die-offs, data necessary to address population and species declines are scarce. Recent studies are beginning to address this deficiency. Stephen Price and colleagues recently reported ranavirusinduced declines in three amphibian species at several sites in northern Spain (Price et al. 2014). Amber Teacher and colleagues analyzed an 11-year dataset in England, and found about an $80 \%$ decline in common frog abundance at ranavirus die-off sites (Teacher et al. 2010). Jim Petranka and several other ecologists have observed no recruitment in consecutive years at sites with ranavirus die-offs (Petranka et al. 2003; Wheelwright et al. 2014). Julia Earl showed in closed populations of wood frogs that reoccurring outbreaks of ranavirus could result in population extinction in as quickly as 5 years (Earl and Gray 2014). These studies suggest that several elements are in place (e.g., high susceptibility among several host species, possible density-independent transmission) for ranaviruses to cause local population extinction and thereby contribute to species declines. However, to date, species extinction due to ranaviral disease has not been reported. This uncertainty emphasizes the need for more intensive investigations in ranavirus surveillance and population monitoring, which is outlined in Gray et al. (2015). Importantly, we should not sit idly until there is definitive evidence of species extinctions due to ranavirus. The writing is on the wall suggesting its potential threat, especially considering that many rare species are hosts for ranaviruses. For example, the highly endangered Chinese giant salamander (Andrias davidianus, Geng et al. 2010), gopher tortoise (Gopherus polyphemus, Westhouse et al. 1996), dusky gopher frog (Lithobates sevosus, Sutton et al. 2014), and boreal toad (Anaxyrus boreas boreas, J. Chaney, M. Gray, and D. Miller, University of Tennessee, unpublished data) are very susceptible to ranaviral disease. Additional investigations are needed to identify other rare species that are highly susceptible (Gray et al. 2015). In captivity, $100 \%$ mortality of hosts is commonly observed likely due to abundant hosts, guaranteed transmission, and stress associated with these environments (Waltzek et al. 2014). Several species of economic (e.g., bullfrogs, Mazzoni et al. 2009; grouper, Qin et al. 2001) and conservation concern (e.g., pallid sturgeon, Waltzek et al. 2014; Chinese giant salamander, Geng et al. 2010; Cunningham et al. 2015) have experienced catastrophic losses in captivity due to ranaviruses. Given this preliminary information on the possible effects of ranaviruses on highly susceptible hosts, we believe it is reasonable to consider this pathogen a serious threat to the biodiversity of ectothermic vertebrate species.

Another question that frequently arises is, "Are ranaviruses emerging?" In other words, "Are ranaviruses increasing in distribution, prevalence, or host range?" Again, this is a challenging question to answer, but there is information that suggests, "Yes." Andrew Storfer provided evidence, based on a lack of coevolutionary history between virus and host, that Ambystoma tigrinum virus (ATV) emerged in some locations (Storfer et al. 2007). His work suggests that emergence of ATV was likely a consequence of the trade in larval salamanders as fishing bait and 
the anthropogenic translocation of sublethally infected salamanders over large geographic distances (Storfer et al. 2007; Picco and Collins 2008). Thomas Waltzek at the University of Florida is currently sequencing the entire genomes of dozens of ranaviruses from around the globe, which will enable him to look at phylogeographic patterns, and identify areas of recent introductions. In general, pathogens emerge in populations either because they are novel or due to an increase in environmental stressors that decrease host immune function. As described above, there is support for the first hypothesis, and it is likely a consequence of pathogen pollution (i.e., the human movement of infected animals or contaminated fomites over large geographic distances, Cunningham et al. 2003). Furthermore, although research is limited, there is evidence that insecticides, herbicides, and the use of wetlands by cattle can act as stressors and increase the chance of ranavirus emergence (Forson and Storfer 2006; Gray et al. 2007; Kerby et al. 2011). In the past 4 years, $>90 \%$ of the cases of ranavirus infection and disease have been reported (Duffus et al. 2015). While enhanced awareness of ranaviruses and increased sampling efforts probably contributes to increased detections, it is unlikely that these factors are solely responsible.

In this contribution, we provide a comprehensive and current review of ranavirus taxonomy (Jancovich et al. 2015a), virus distribution (Duffus et al. 2015), hostpathogen ecology and evolution (Brunner et al. 2015), viral replication strategies (Jancovich et al. 2015b), host antiviral immunity and viral countermeasures (Grayfer et al. 2015), ranavirus pathology and diagnosis (Miller et al. 2015), and suggestions for the design and analysis of ranavirus studies (Gray et al. 2015). Collectively, this work provides an up-to-date overview of ranaviruses and their impacts on host organisms, and reflects the contributions of investigators (i.e., molecular virologists, immunologists, ecologists, veterinary pathologists, population biologists) possessing diverse skills, but united in their interest in ranaviruses and the diseases they cause.

In addition to this book, professionals around the globe have been working together to learn about ranaviruses. For example, two international symposia devoted to ranaviruses (Minneapolis, Minnesota, 2011; Knoxville, Tennessee, 2013) brought together scientists interested in understanding ranaviruses and their disease potential (Lesbarrères et al. 2012; Duffus et al. 2014). A third symposium is planned for Gainesville, Florida, USA in 2015. Between the 2011 and 2013 symposia, investigators interested in ranaviruses founded the Global Ranavirus Consortium (GRC). The goal of the GRC is to facilitate communication and collaboration among scientists and veterinarians conducting research on ranaviruses and diagnosing cases of ranaviral disease. Specifically, the GRC aims to: (1) advance knowledge in all areas of ranavirus biology and disease, (2) facilitate multidisciplinary, scientific collaborations, (3) disseminate information on ranaviruses, and (4) provide expert guidance and training opportunities. The GRC accomplishes these goals by hosting a biennial symposium, organizing regional workshops and discussion groups, and maintaining a website (http://ranavirus.org) with various resources including a current list of ranavirus publications and laboratories that test for the pathogen. They also are leading an effort to create a Global Ranavirus Reporting System, which will be an online data management system that allows cases of ranavirus infection and disease 
to be uploaded, mapped, and downloaded by users. The GRC announced charter membership in 2015.

So, what does the future look like for ranaviruses? We are just beginning to scratch the surface in understanding the complex interactions between these pathogens and their diverse hosts. More information is needed on basic molecular biology of ranaviruses, immunological responses of hosts, and resulting pathologies as outlined in Jancovich et al. (2015b), Grayfer et al. (2015), and Miller et al. (2015). These data are fundamental to understanding underlying mechanisms to ranavirushost interactions. More research is needed to understand why ranaviruses emerge in certain areas. Are the factors related to basic epidemiological principles (e.g., density-independent transmission), natural stressors (e.g., breeding), anthropogenic stressors (e.g., pesticides), or recent pathogen introduction? To answer these questions laboratory experiments need to be coupled with field research, and host health assessments performed by immunologists and pathologists. We also do not understand the potential effects of climate change on ranavirus distribution and pathogenicity. Given that many ranaviruses replicate faster at warmer temperatures (Ariel et al. 2009), it is possible that atmospheric warming could contribute to emergence. For amphibians, we also know that rapidly drying breeding sites, which could increase in some regions due to climate change, stress larvae and may contribute to disease severity. Another factor is the apparent increase in pathogenicity of ranaviruses associated with die-offs in captive facilities, typically those associated with aquaculture or frog farms (Brunner et al. 2015). If this hypothesis is correct, trade of ectothermic vertebrates could be moving highly virulent ranavirus strains around the globe, which emphasizes the need to implement regulations on pretesting animals as recommended by the World Organization for Animal Health (Schloegel et al. 2010). When we think about commerce, international trade is generally of greatest concern. However, as Andrew Storfer's study showed, movement over small geographic distances (several $100 \mathrm{~km}$ ) can be enough to result in emergence (Storfer et al. 2007). Interestingly, we recently finished controlled experiments that suggest as little as $100 \mathrm{~km}$ may be far enough to result in differences in coevolutionary history between ranavirus and a host, resulting in increased levels of mortality (P. Reilly, M. Gray, D. Miller, University of Tennessee, unpublished data). Collectively, the data suggest that ranavirus emergence likely reflects the combined effects of human-induced spread, increased environmental stress, depressed host immunity, and enhanced virulence.

In the nearly 50 years since the discovery of FV3, ranaviruses have gone from being merely a curiosity (i.e., a virus family with interesting molecular aspects but of little commercial or medical importance) to a genus whose members have profound impacts, both potentially and actually, on animal health and well-being. Moreover, studies of amphibian responses to ranavirus infection have advanced our understanding of antiviral immunity in lower vertebrates and suggested pathways for vaccine development. This work has validated the view proposed more than 30 years ago that unusual organisms are studied, not just because they are odd, but also because they provide insights into fundamental biological processes common to all organisms. 
Acknowledgments Open Access publication was made possible through grants provided by the University of Tennessee (Institute of Agriculture, Office of Research and Engagement, and Department of Forestry, Wildlife, and Fisheries), Washington State University Libraries, Gordon State College (Office of Academic Affairs), the Association of Reptilian and Amphibian Veterinarians, and the Amphibian and Reptile Conservancy.

Open Access This chapter is distributed under the terms of the Creative Commons Attribution Noncommercial License, which permits any noncommercial use, distribution, and reproduction in any medium, provided the original author(s) and source are credited.

\section{References}

Ariel E, Nicolajsen N, Christophersen MB, Holopainen R, Tapiovaara H, Jensen BB (2009) Propagation and isolation of ranaviruses in cell culture. Aquaculture 294:159-164

Brunner JL, Storfer A, Gray MJ, Hoverman JT (2015) Ranavirus ecology and evolution: from epidemiology to extinction. In: Gray MJ, Chinchar VG (eds) Ranaviruses: lethal pathogens of ectothermic vertebrates. Springer, New York

Chinchar VG, Hyatt A, Miyazaki T, Williams T (2009) Family Iridoviridae: poor viral relations no longer. Curr Top Microbiol Immunol 328:123-170

Cunningham AA, Daszak P, Rodriguez JP (2003) Pathogen pollution: defining a parasitological threat to biodiversity conservation. J Parasitol 89(suppl):S78-S83

Cunningham AA, Turvey ST, Zhou F (2015) Development of the Chinese giant salamander Andrias davidianus farming industry in Shaanxi Province, China: conservation threats and opportunities. Fauna \& Flora International, Oryx doi:10.1017/S0030605314000842. http:// journals.cambridge.org/orx/salamanderchina

Duffus ALJ, Gray MJ, Miller DL, Brunner JL (2014) Second international symposium on ranaviruses: a North American herpetological perspective. J North Am Herpetol 2014:105-107

Duffus ALJ, Waltzek TB, Stöhr AC, Allender MC, Gotesman M, Whittington RJ, Hick P, Hines MK, Marschang RE (2015) Distribution and host range of ranaviruses. In: Gray MJ, Chinchar VG (eds) Ranaviruses: lethal pathogens of ectothermic vertebrates. Springer, New York

Earl JE, Gray MJ (2014) Introduction of ranavirus to isolated wood frog populations could cause local extinction. EcoHealth 11:581-592

Forson DD, Storfer A (2006) Atrazine increases ranavirus susceptibility in the tiger salamander, Ambystoma tigrinum. Ecol Appl 16:2325-2332

Geng Y, Wang KY, Zhou ZY, Li CW, Wang J, He M, Yin ZQ, Lai WM (2010) First report of a ranavirus associated with morbidity and mortality in farmed Chinese giant salamanders (Andrias davidianus). J Comp Pathol. doi:10.1016/j.jcpa.2010.11.012

Granoff A, Came PE, Breeze DC (1966) Viruses and renal carcinoma of Rana pipiens: I. The isolation and properties of virus from normal and tumor tissues. Virology 29:133-148

Gray MJ, Miller DL, Schmutzer AC, Baldwin CA (2007) Frog virus 3 prevalence in tadpole populations inhabiting cattle-access and non-access wetlands in Tennessee, USA. Dis Aquat Organ 77:97-103

Gray MJ, Brunner JL, Earl JE, Ariel E (2015) Design and analysis of ranavirus studies: surveillance and assessing risk. In: Gray MJ, Chinchar VG (eds) Ranaviruses: lethal pathogens of ectothermic vertebrates. Springer, New York

Grayfer L, Edholm E-S, De Jesús Andino F, Chinchar VG, Robert J (2015) Ranavirus host immunity and immune evasion. In: Gray MJ, Chinchar VG (eds) Ranaviruses: lethal pathogens of ectothermic vertebrates. Springer, New York

Jancovich JK, Steckler N, Waltzek TB (2015a) Ranavirus taxonomy and phylogeny. In: Gray MJ, Chinchar VG (eds) Ranaviruses: lethal pathogens of ectothermic vertebrates. Springer, New York 
Jancovich JK, Qin Q, Zhang Q-Y, Chinchar VG (2015b) Ranavirus replication: molecular, cellular, and immunological events. In: Gray MJ, Chinchar VG (eds) Ranaviruses: lethal pathogens of ectothermic vertebrates. Springer, New York

Kerby JL, Hart AJ, Storfer A (2011) Combined effects of virus, pesticide, and predator cue on the larval tiger salamander (Ambystoma tigrinum). Ecohealth 8:46-54

Lesbarrères D, Balseiro A, Brunner J, Chinchar VG, Duffus A, Kerby J, Miller DL, Robert J, Schock DM, Waltzek T, Gray MJ (2012) Ranavirus: past, present and future. Biol Lett 8: 481-483

Mazzoni R, de Mesquita AJ, Fleury LFF, de Brito W et al (2009) Mass mortality associated with a frog virus 3-like ranavirus infection in farmed tadpoles Rana catesbeiana from Brazil. Dis Aquat Organ 86:181-191

Miller DL, Pessier AP, Hick P, Whittington RJ (2015) Comparative pathology of ranaviruses and diagnostic techniques. In: Gray MJ, Chinchar VG (eds) Ranaviruses: lethal pathogens of ectothermic vertebrates. Springer, New York

Murti KG, Goorha R, Granoff A (1985) An unusual replication strategy of an animal virus. Adv Virus Res 30:1-19

Price, SJ, Garner TWJ, Nichols RA, et al. (2014) Collapse of amphibian communities due to an introduced Ranavirus. Curr Biol 24:2586-2591. http://www.cell.com/current-biology/pdfExtended/ S0960-9822(14)01149-X

Petranka JW, Murray SS, Kennedy CA (2003) Responses of amphibians to restoration of a southern Appalachian wetland: perturbations confound post-restoration assessment. Wetlands 23: 278-290

Pico AM, Collins JP (2008) Amphibian commerce as a likely source of pathogen pollution. Conserv Biol 22:1582-1589

Qin QW, Lam TJ, Sin YM, Shen H, Chang SF, Ngoh GH, Chen CL (2001) Electron microscopic observations of a marine fish iridovirus isolated from brown-spotted grouper, epinepheous tauvina. J Virol Methods 98:17-24

Schloegel LM, Daszak P, Cunningham AA, Speare R, Hill B (2010) Two amphibian diseases, chytridiomycosis and ranaviral disease, are now globally notifiable to the world organization for animal health (OIE): an assessment. Dis Aquat Organ 92:101-108

Storfer A, Alfaro ME, Ridenhour BJ, Jancovich JK, Mech SG, Parris MJ, Collins JP (2007) Phylogenetic concordance analysis shows an emerging pathogen is novel and endemic. Ecol Lett 10:1075-1083

Sutton WB, Gray MJ, Hardman RH, Wilkes RP, Kouba A, Miller DL (2014) High susceptibility of the endangered dusky gopher frog to ranavirus. Dis Aquat Organ 112:9-16

Teacher AGF, Cunningham AA, Garner TWJ (2010) Assessing the long-term impact of ranavirus infection in wild common frog populations. Anim Conserv 13:514-522

Waltzek TB, Miller DB, Gray MJ, Drecktrah B, Briggler JT, MacConnel B, Hudson C, Hopper L, Friary J, Yun SC, Maim KV, Weber ES, Hedrick RP (2014) New disease records for hatcheryreared sturgeon I. Expansion of frog virus 3 host range into Scaphirhynchus albus. Dis Aquat Org 111:219-227

Westhouse RA, Jacobson ER, Harris RK et al (1996) Respiratory and pharyngo-esophageal iridovirus infection in a gopher tortoise (Gopherus polyphemus). J Wild Dis 32:682-686

Wheelwright NT, Gray MJ, Hill RD, Miller DL (2014) Sudden mass die-off of a large population of wood frog (Lithobates sylvaticus) tadpoles in Maine, USA, likely due to ranavirus. Herpetol Rev 45:240-242

Williams T (1996) The Iridoviruses. Adv Virus Res 46:345-411

Williams T, Barbosa-Solomieu V, Chinchar VG (2005) A decade of advances in iridovirus research. Adv Virus Res 65:173-248

Wissenberg R (1965) Fifty years of research on the lymphocystis virus disease of fishes (1914-1964). Ann N Y Acad Sci 126:362-374

Xeros N (1954) A second virus disease of the leather jacket, Tipula paludosa. Nature (London) $174: 562-563$ 


\title{
Distribution and Host Range of Ranaviruses
}

\author{
Amanda L.J. Duffus, Thomas B. Waltzek, Anke C. Stöhr, \\ Matthew C. Allender, Michael Gotesman, Richard J. Whittington, \\ Paul Hick, Megan K. Hines, and Rachel E. Marschang
}

\section{Introduction}

The genus Ranavirus is a group of globally emerging pathogens infecting fish, amphibians, and reptiles, impacting both captive and wild animals. Ranaviruses are pathogens capable of infecting multiple species at a site (e.g., Mao et al. 1999a;

\footnotetext{
A.L.J. Duffus $(\bowtie)$

Department of Biology, Gordon State College, Barnesville, GA, USA

e-mail: aduffus@gordonstate.edu
}

T.B. Waltzek • M. Gotesman

Department of Infectious Diseases and Pathology, College of Veterinary Medicine,

University of Florida, Gainesville, FL, USA

e-mail: tbwaltzek@ufl.edu; mgotesman@ufl.edu

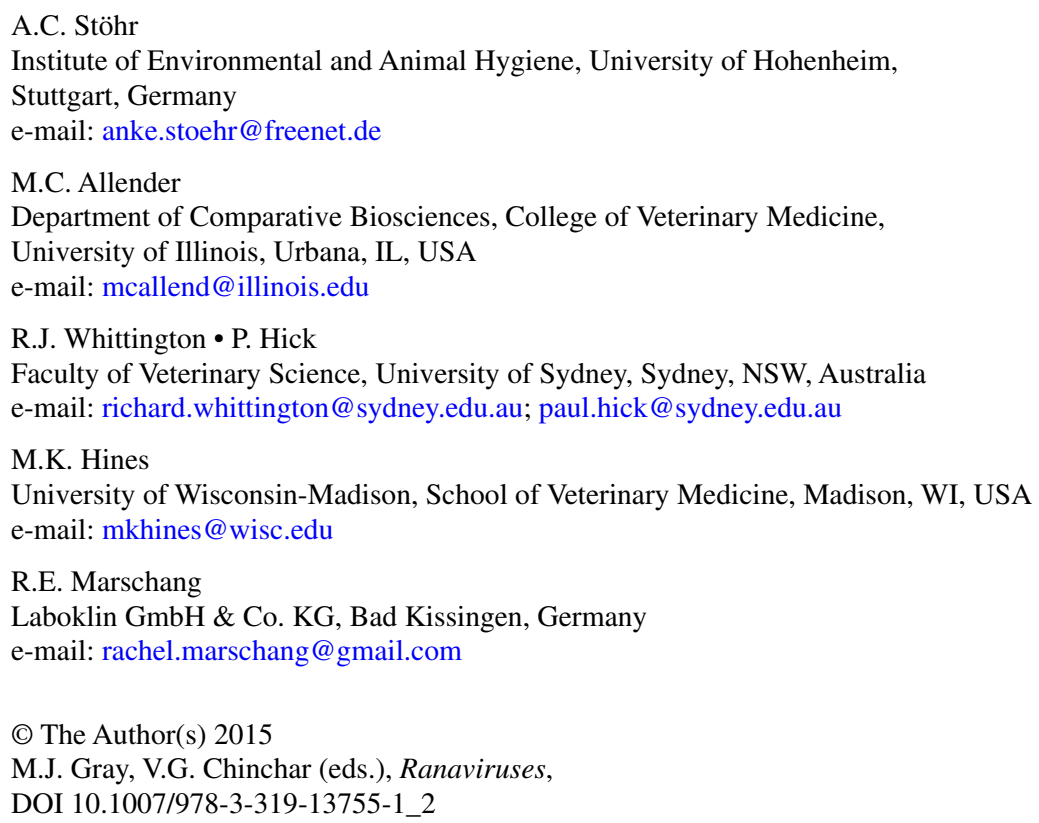


Duffus et al. 2008), and can be transmitted between taxonomic classes of ectothermic vertebrates (e.g., Brenes et al. 2014a, b; Brunner et al. 2015). Ranaviruses are known to infect at least 175 species across 52 families of ectothermic vertebrates, and are found on all continents but Antarctica (Table 1; Figs. 1 and 2). Most of what is known

Table 1 The taxonomic distribution of ranavirus cases among amphibian, fish, and reptilian hosts

\begin{tabular}{|c|c|c|}
\hline & Family & No. species affected \\
\hline \multirow[t]{18}{*}{ Amphibians } & Alytidae & 1 \\
\hline & Ambystomatidae & $8^{\mathrm{a}}$ \\
\hline & Bufonidae & 8 \\
\hline & Centrolenidae & 1 \\
\hline & Craugastoridae & 3 \\
\hline & Cryptobranchidae & 2 \\
\hline & Dendrobatidae & 5 \\
\hline & Hylidae & 15 \\
\hline & Hynobiidae & 1 \\
\hline & Leptodactylidae & $2^{\mathrm{a}}$ \\
\hline & Megophryidae & 1 \\
\hline & Myobatrachidae & 2 \\
\hline & Pipidae & 1 \\
\hline & Plethodontidae & 21 \\
\hline & Ranidae & $22^{\mathrm{a}}$ \\
\hline & Rhacophoridae & 1 \\
\hline & Salamandridae & 8 \\
\hline & Scaphiopodidae & 1 \\
\hline \multirow[t]{22}{*}{ Fish } & Acipenseridae & 3 \\
\hline & Anguillidae & 1 \\
\hline & Centrarchidae & 9 \\
\hline & Channidae & 1 \\
\hline & Catostomidae & 1 \\
\hline & Cyprinidae & 2 \\
\hline & Eleotridae & 1 \\
\hline & Esocidae & 2 \\
\hline & Gadidae & 1 \\
\hline & Gasterosteidae & 1 \\
\hline & Ictaluridae & 2 \\
\hline & Labridae & 1 \\
\hline & Latidae & 1 \\
\hline & Lutjanidae & 1 \\
\hline & Moronidae & 3 \\
\hline & Percidae & 2 \\
\hline & Poeciliidae & 1 \\
\hline & Salmonidae & 1 \\
\hline & Sciaenidae & 1 \\
\hline & Scophthalmidae & 1 \\
\hline & Serranidae & 4 \\
\hline & Siluridae & 1 \\
\hline
\end{tabular}

(continued) 
Table 1 (continued)

\begin{tabular}{l|l|l}
\hline & Family & No. species affected \\
\hline \multirow{4}{*}{ Reptiles } & Agamidae & 2 \\
\cline { 2 - 3 } & Anguidae & 1 \\
\cline { 2 - 3 } & Boidae & 1 \\
\cline { 2 - 3 } & Dactyloidae & 2 \\
\cline { 2 - 3 } Emydidae & 4 \\
\cline { 2 - 3 } & Gekkonidae & 1 \\
\cline { 2 - 3 } & Iguanidae & 1 \\
\cline { 2 - 3 } & Lacertidae & 2 \\
\cline { 2 - 3 } & Pythonidae & 4 \\
\cline { 2 - 3 } & Testudinidae & 8 \\
\cline { 2 - 3 } & Trionychidae & 1 \\
\cline { 2 - 3 } & Varanidae & 1 \\
\hline
\end{tabular}

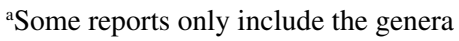

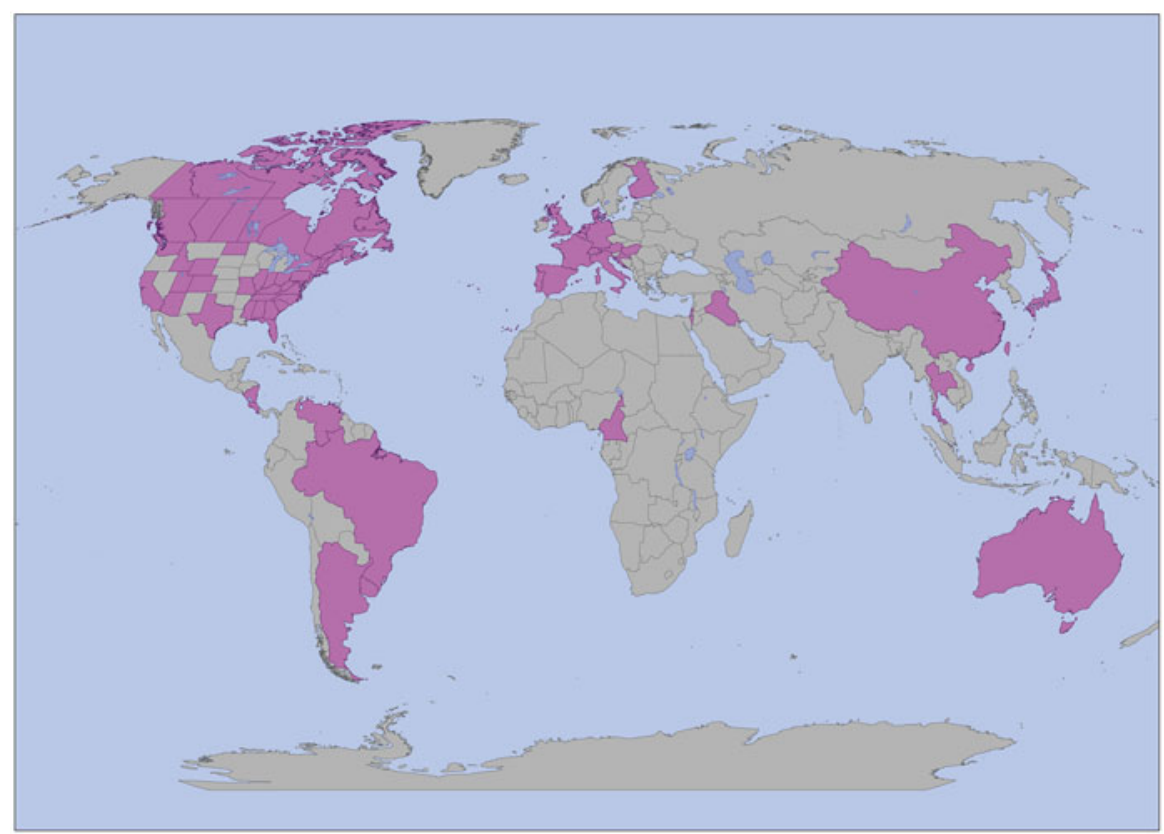

Fig. 1 Global distribution of ranavirus cases

about the epidemiology, geography, and host range of ranaviruses comes from investigations of obvious die-offs, sporadic surveillance efforts in small numbers of populations at one or two time points, and a few larger-scale surveillance efforts focused on a handful of species of economic importance or conservation interest (Grizzle and Brunner 2003; Gray et al. 2009b; Whittington et al. 2010; Miller et al. 2011; Gray et al. 2015). Because gross signs of infection may not be displayed, many host species are cryptic and difficult to detect, the lack of awareness of ranaviruses as significant pathogens, and occasional misdiagnosis, the known geographic distribution and host range of ranaviruses are likely underestimated. 

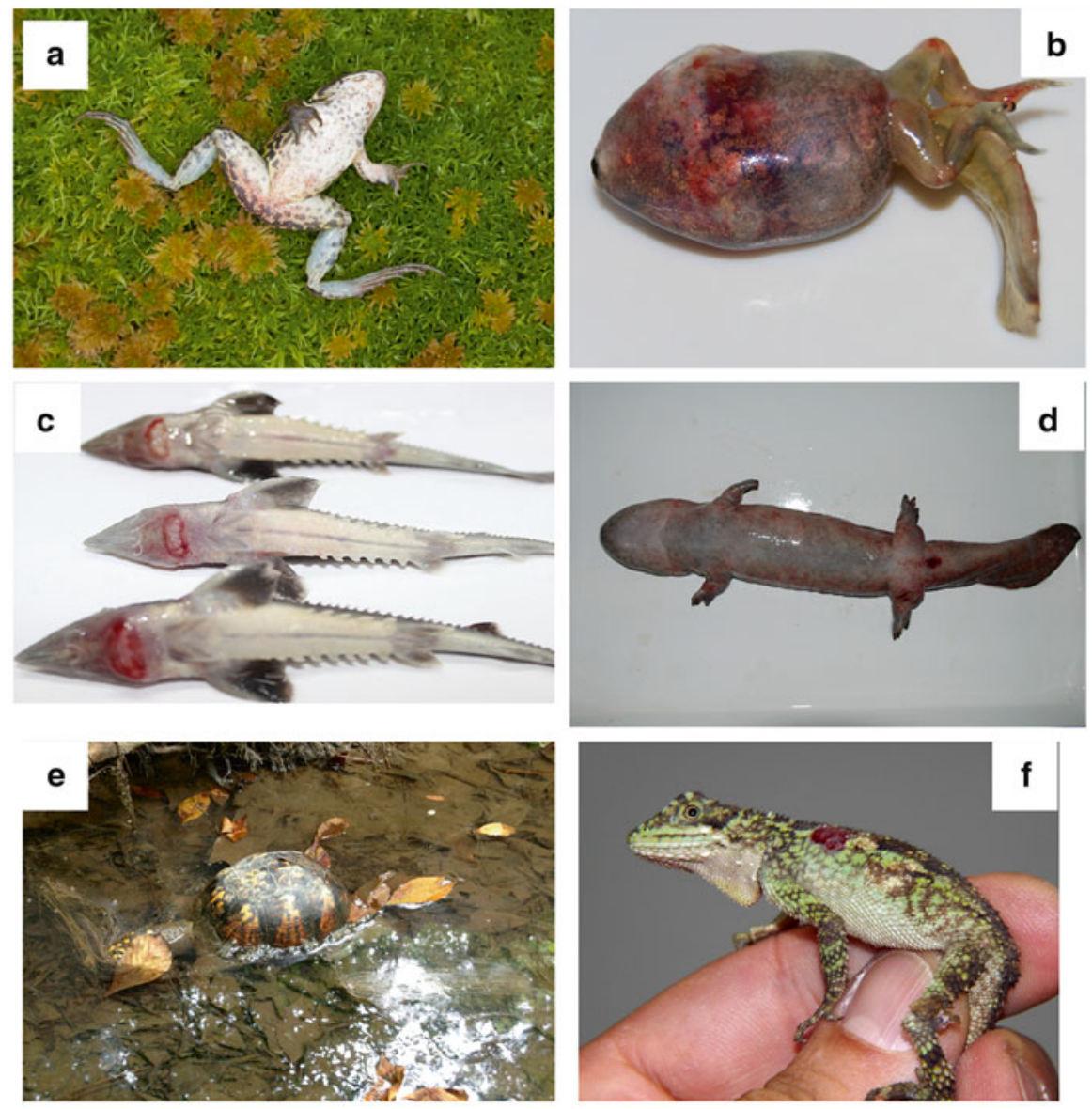

Fig. 2 Ranaviruses are known to cause disease in three ectothermic vertebrate classes. (a) Dead adult edible frog (Rana esculenta) in the Netherlands (credit=Jeiger Herder), (b) morbid plains spadefoot (Spea bombifrons) in the USA (credit=Drew Davis), (c) infected Amur sturgeon (Acipenser schrenckii) in China (credit $=$ Yi Geng), $(\mathbf{d})$ morbid juvenile Chinese giant salamander (Andrias davidianus) in China (credit=Lingbing Zeng), (e) dead eastern box turtle (Terrapene carolina carolina) in the USA (credit=Matthew Allender), and $(\mathbf{f})$ infected green striped tree dragon (Japalura splendida) with ranavirus-associated dermatitis in Germany (credit=Helge Behncke)

Ranaviruses are classified as emerging pathogens, because their geographic distribution and host range appear to be expanding (Daszak et al. 1999). It is becoming evident that ranaviruses are frequently moved in the regional and international trade of animals. For example, barred tiger salamander (Ambystoma mavortium) larvae are sold as fishing bait in the southwestern USA, and as many as $100 \%$ have been shown to be infected with the ranavirus, Ambystoma tigrinum virus (ATV; Picco and Collins 2008; Brunner et al. 2015). Amphibian ranaviruses have been found in animals that are traded over international borders for a variety of reasons, including human consumption and the pet trade (Schloegel et al. 2009; Kolby et al. 2014). Schloegel et al. (2009) found that $8.5 \%$ of amphibians imported into the USA at three major port 
cities were infected with ranavirus. Similarly, Kolby et al. (2014) found over $50 \%$ of amphibians exported via Hong Kong International Airport were infected with ranavirus. Reptiles infected with ranaviruses also have been discovered in internationally traded animals (Hyatt et al. 2002; Stöhr et al. 2013b, 2015). Finally, internationally traded ornamental fishes have been shown to be infected with ranaviruses (Hedrick and McDowell 1995).

While the outcome of infection varies among hosts and strains of ranaviruses, it is clear that ranaviruses have the potential to cause population declines and extinctions (Teacher et al. 2010; Price et al. 2014; Earl and Gray 2014). They may present a significant threat to host species that are geographically isolated or exist at low abundance (Heard et al. 2013; Price et al. 2014; Earl and Gray 2014). Thus, highly susceptible host species that are rare may be at greatest risk (Earl and Gray 2014). However, common species also can be affected. For example, populations of the common frog (Rana temporaria) have declined on average $80 \%$ in the UK where ranavirus die-offs have reoccurred (Teacher et al. 2010). It is therefore important to understand the geographic extent, host range, and phylogenetic relationships of these emerging pathogens (Jancovich et al. 2015).

\section{Ranaviruses Infecting Amphibians}

The first ranaviruses were isolated from northern leopard frogs (Lithobates pipiens) from the Midwest USA in the 1960s (Granoff et al. 1965; Clark et al. 1968). One of these viruses, isolated from a frog with adenocarcinoma, was designated Frog virus 3 (FV3; Granoff et al. 1965), and became the type species of the genus, Ranavirus. While many aspects of FV3 virology were well characterized in the following decades (Chinchar 2002), there were few reports of ranaviral disease associated with amphibians so the pathogen received little attention. A second species of Ranavirus, Bohle iridovirus (BIV), was not isolated from amphibians until the early 1990s. This virus was detected in captive animals in Australia (Speare and Smith 1992). About the same time, epizootic die-offs were being recorded in the southwestern USA and the UK (Collins et al. 1988; Cunningham et al. 1993), but it was not until the mid-1990s that the etiology of the disease was determined to be a ranavirus (Drury et al. 1995; Cunningham et al. 1996; Jancovich et al. 1997, Fig. 2). Reports of ranavirus-related mortality and infection in amphibians have grown exponentially, with over $90 \%$ of reports occurring after 2010. Although greater awareness and more surveillance for the pathogen have impacted this trend, the increase in ranavirus cases is likely not solely a sampling artifact. We now realize that the distribution of amphibian ranaviruses is global, and die-offs are occurring in places where these viruses were previously undetected.

Ranaviruses have a global distribution (Fig. 1; Table 2), and have been identified as threats to amphibian populations (e.g., Duffus and Cunningham 2010; Teacher et al. 2010; Miller et al. 2011). Amphibian ranaviruses have been reported in at least 105 species of amphibians in 18 families in 25 countries (Fig. 3; Table 2). These numbers are likely underestimated because many amphibians are cryptic in nature or rare, gross signs 


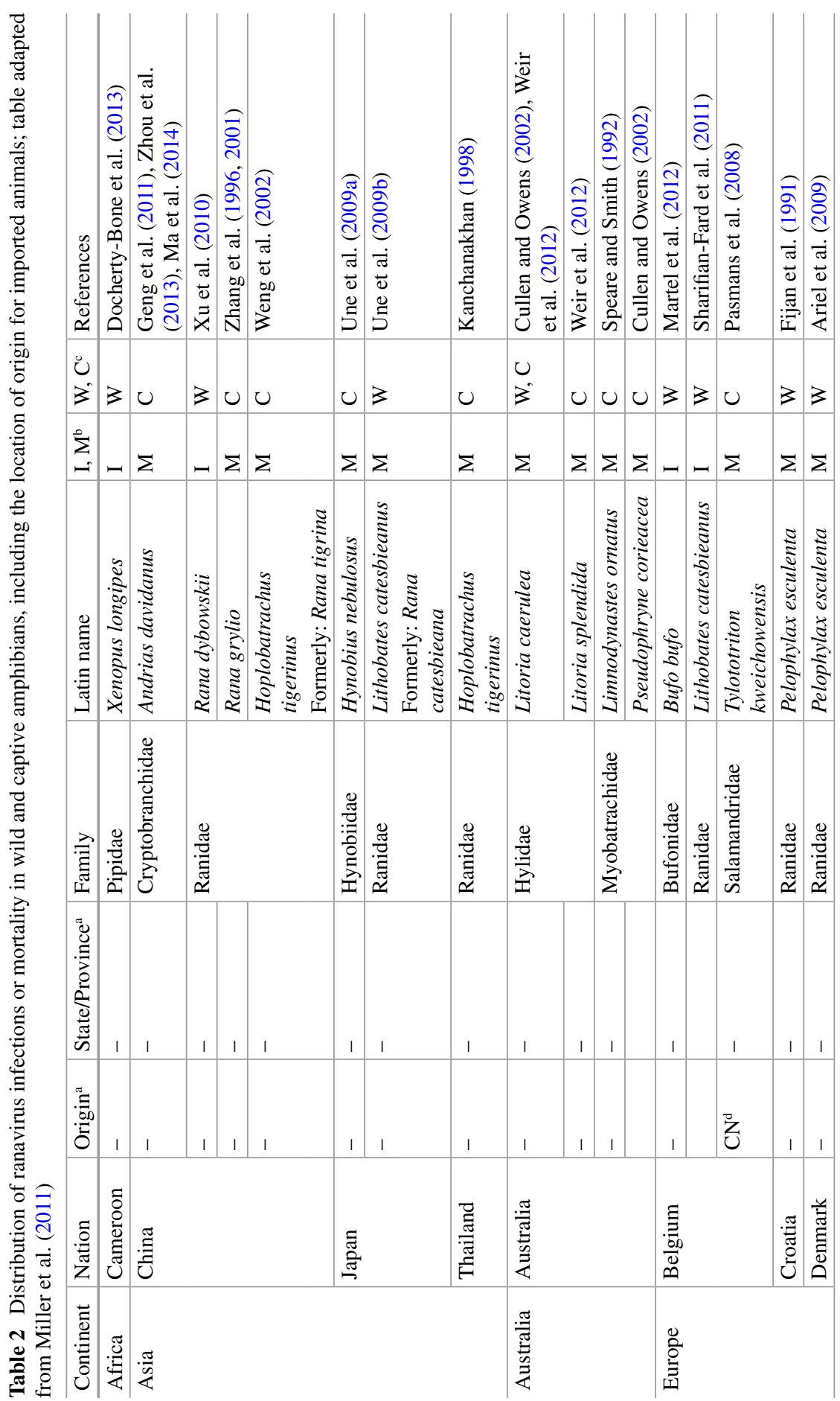




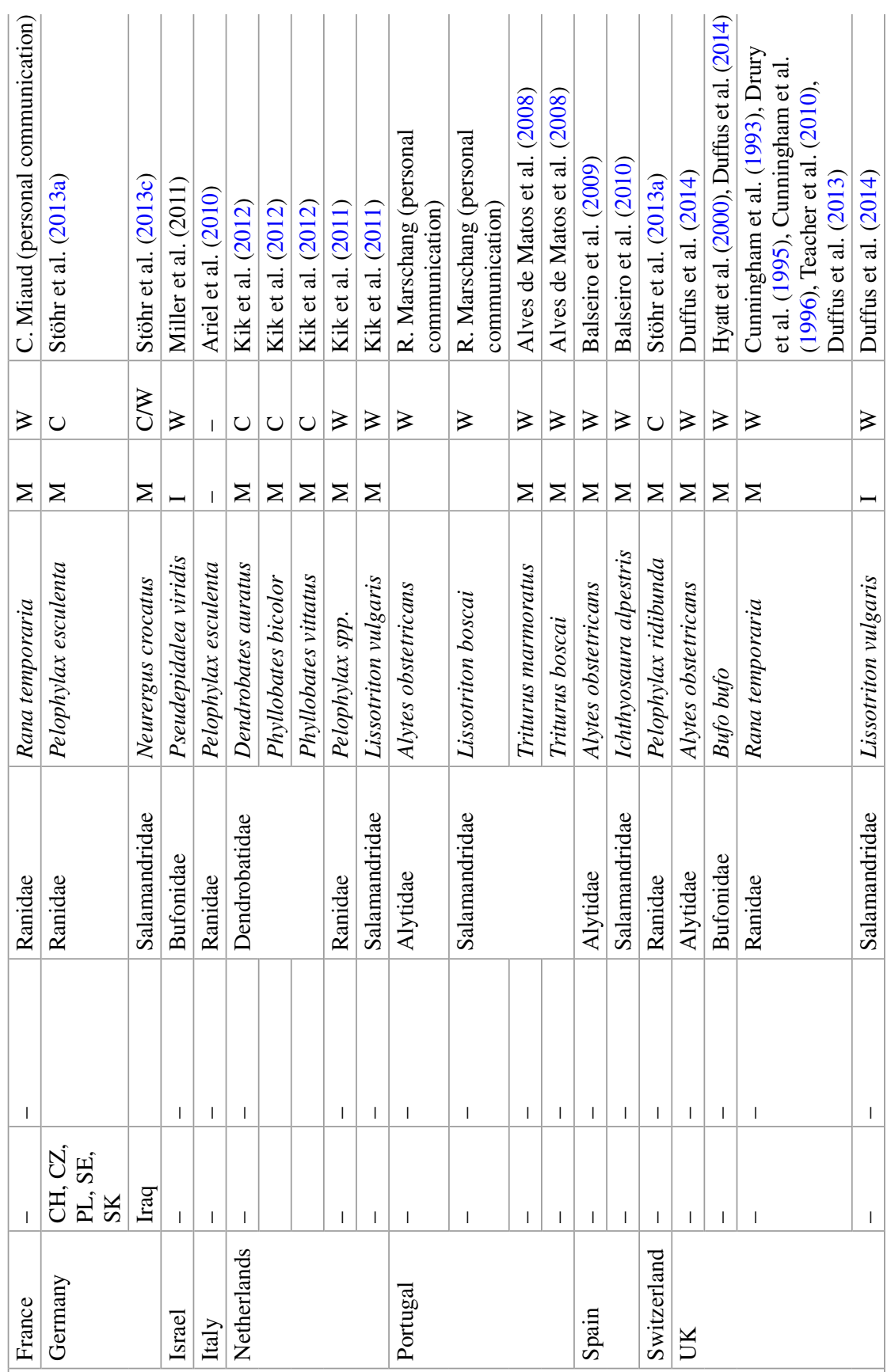




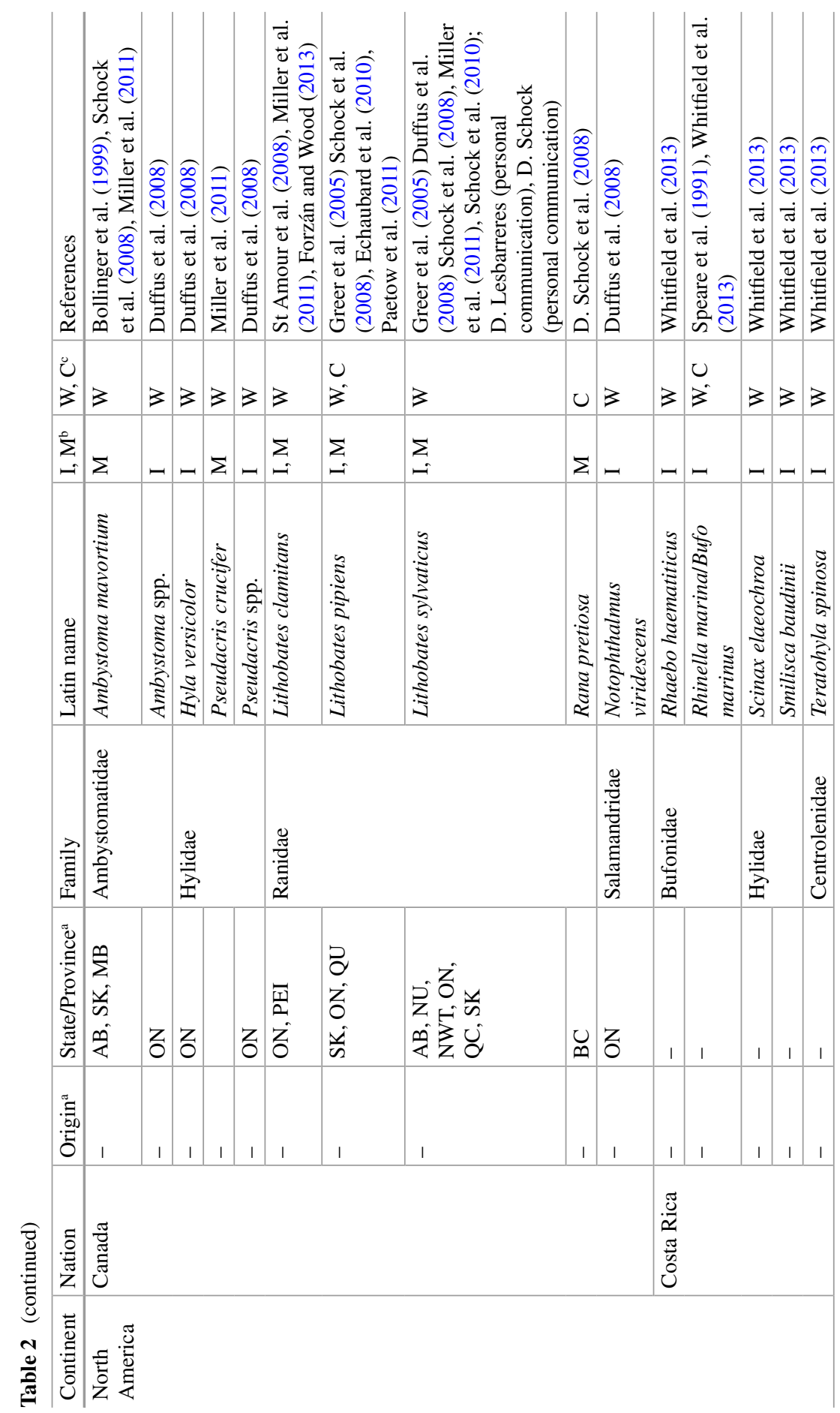




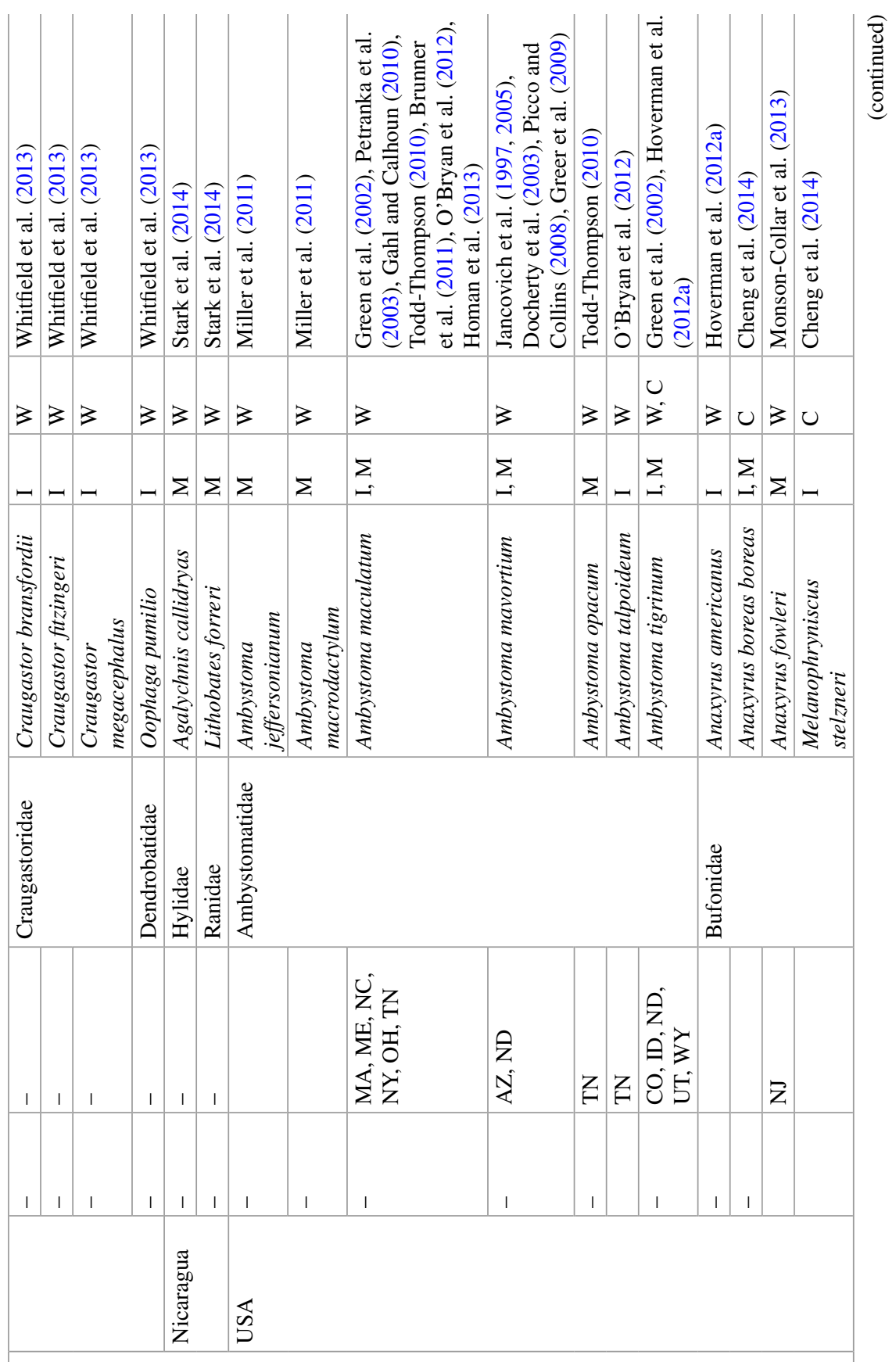




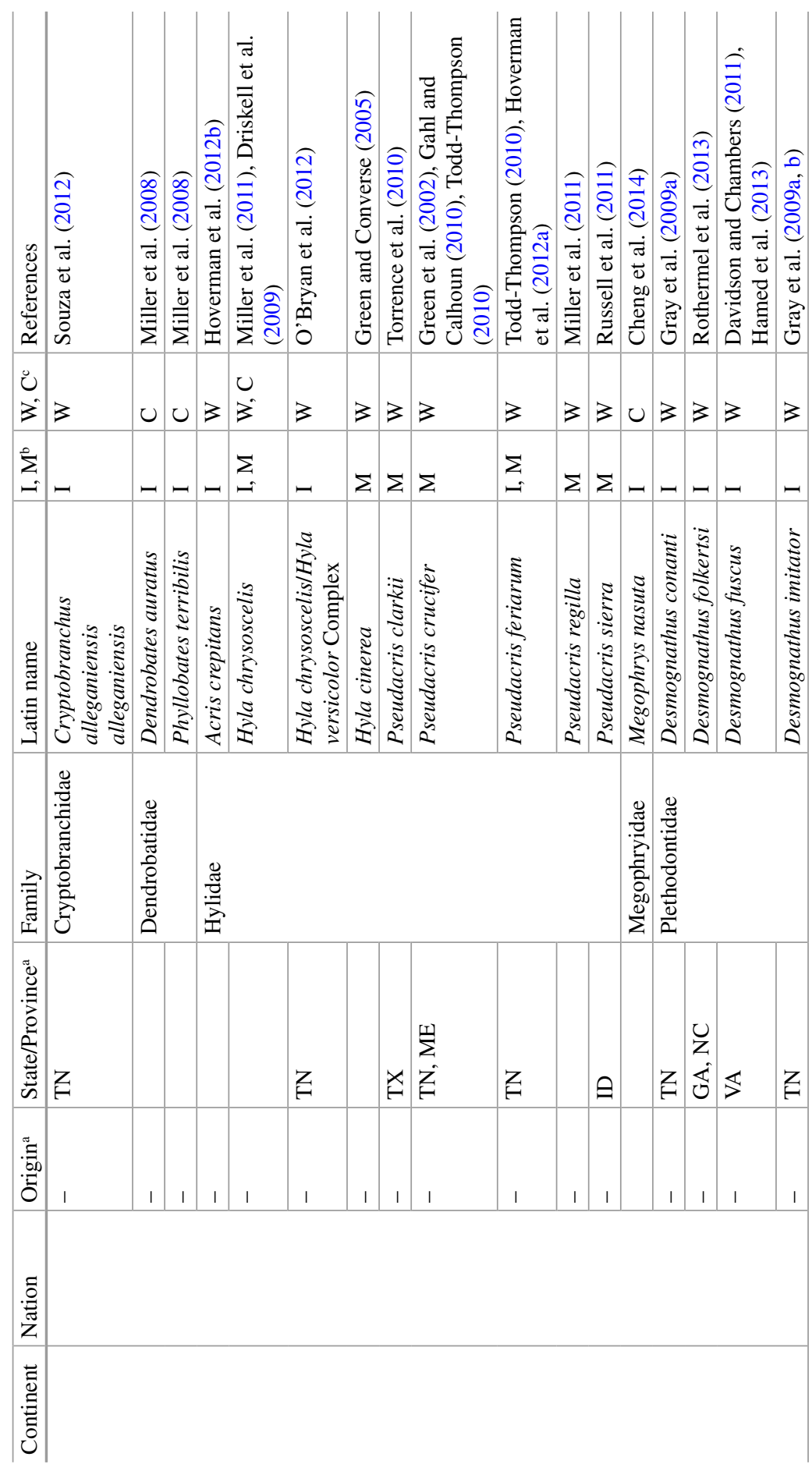




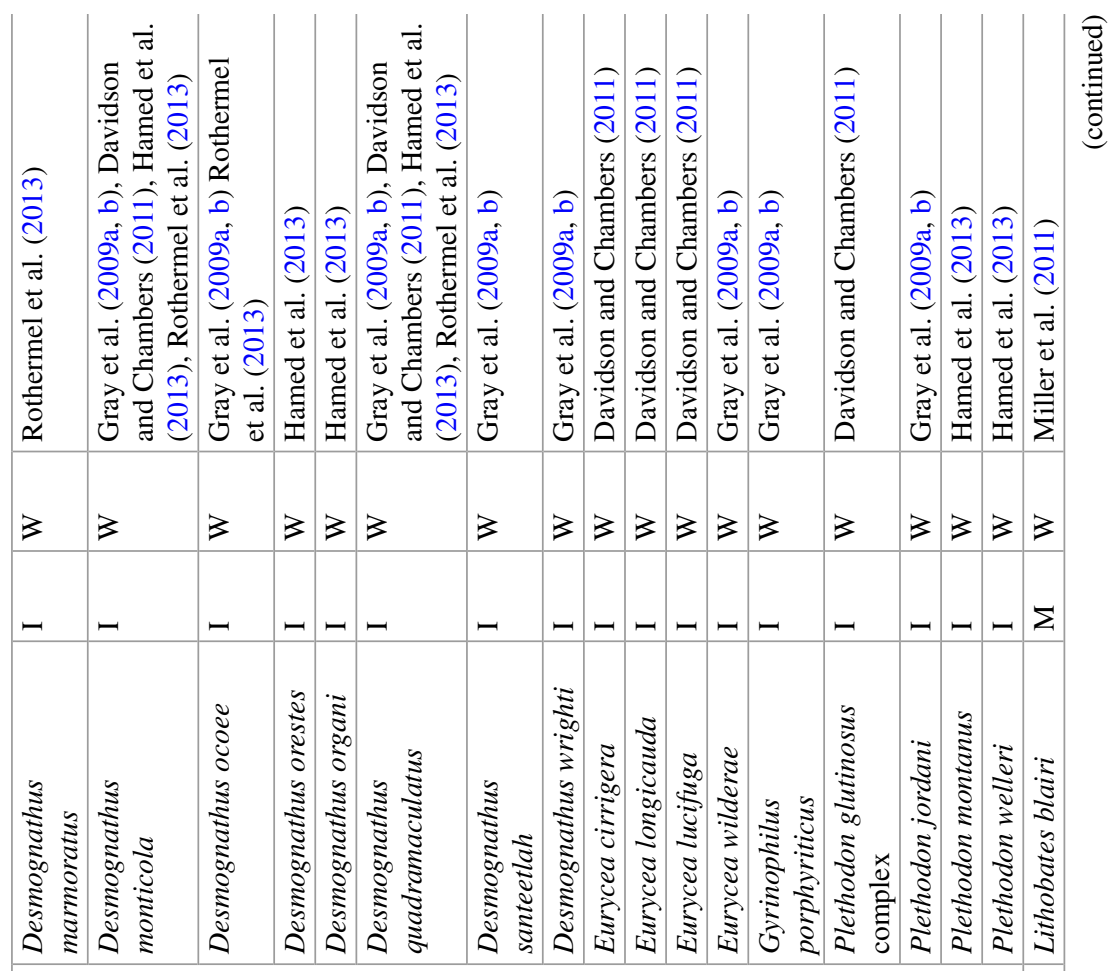

高

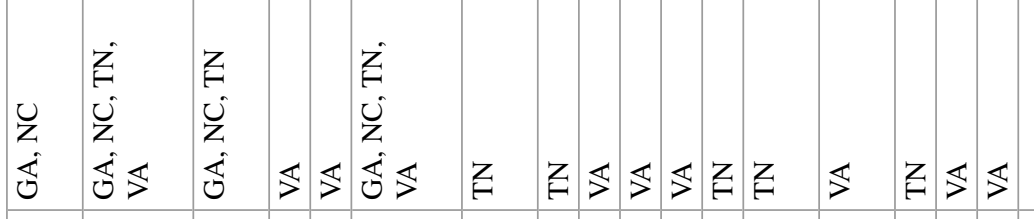




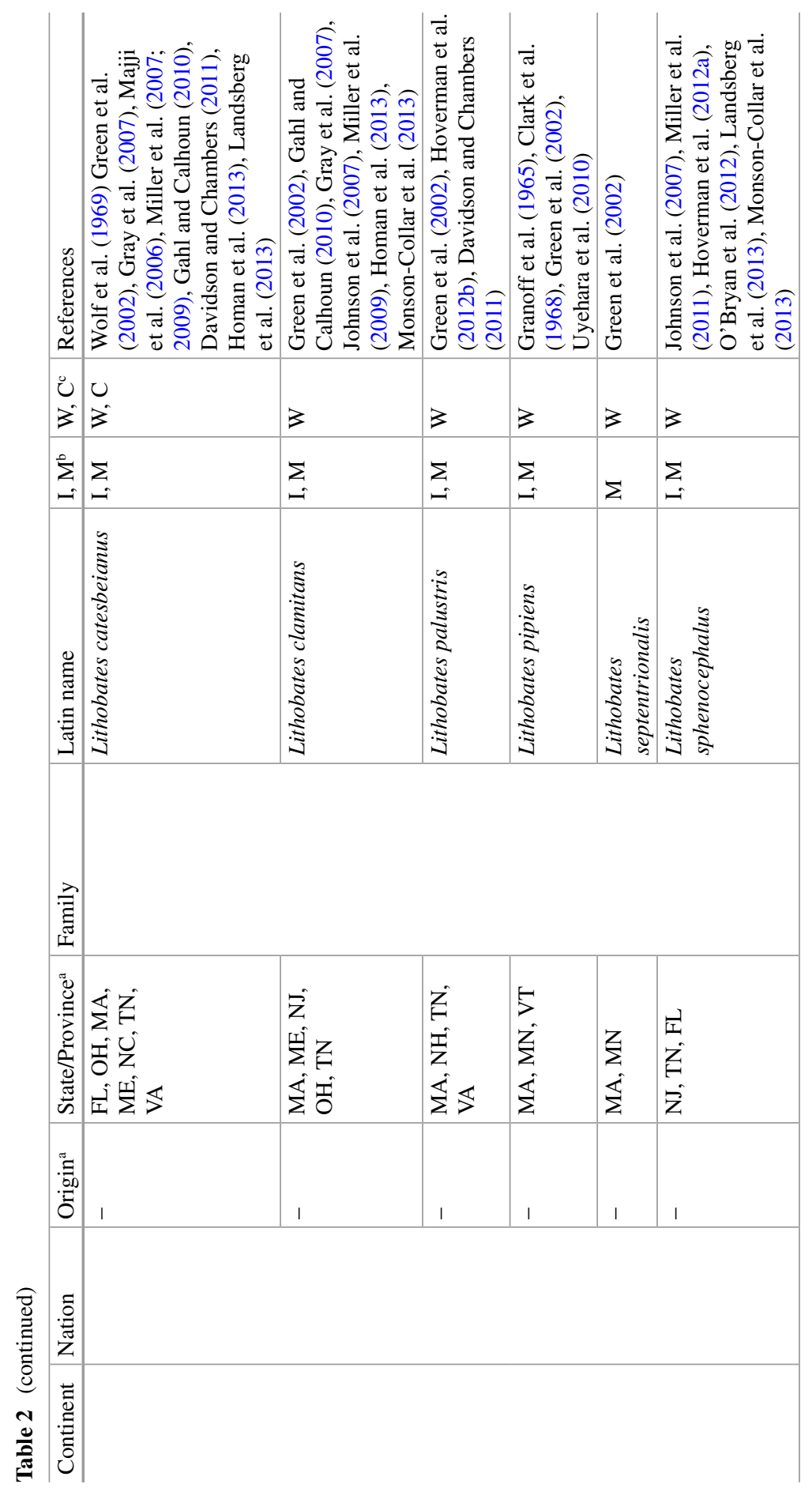




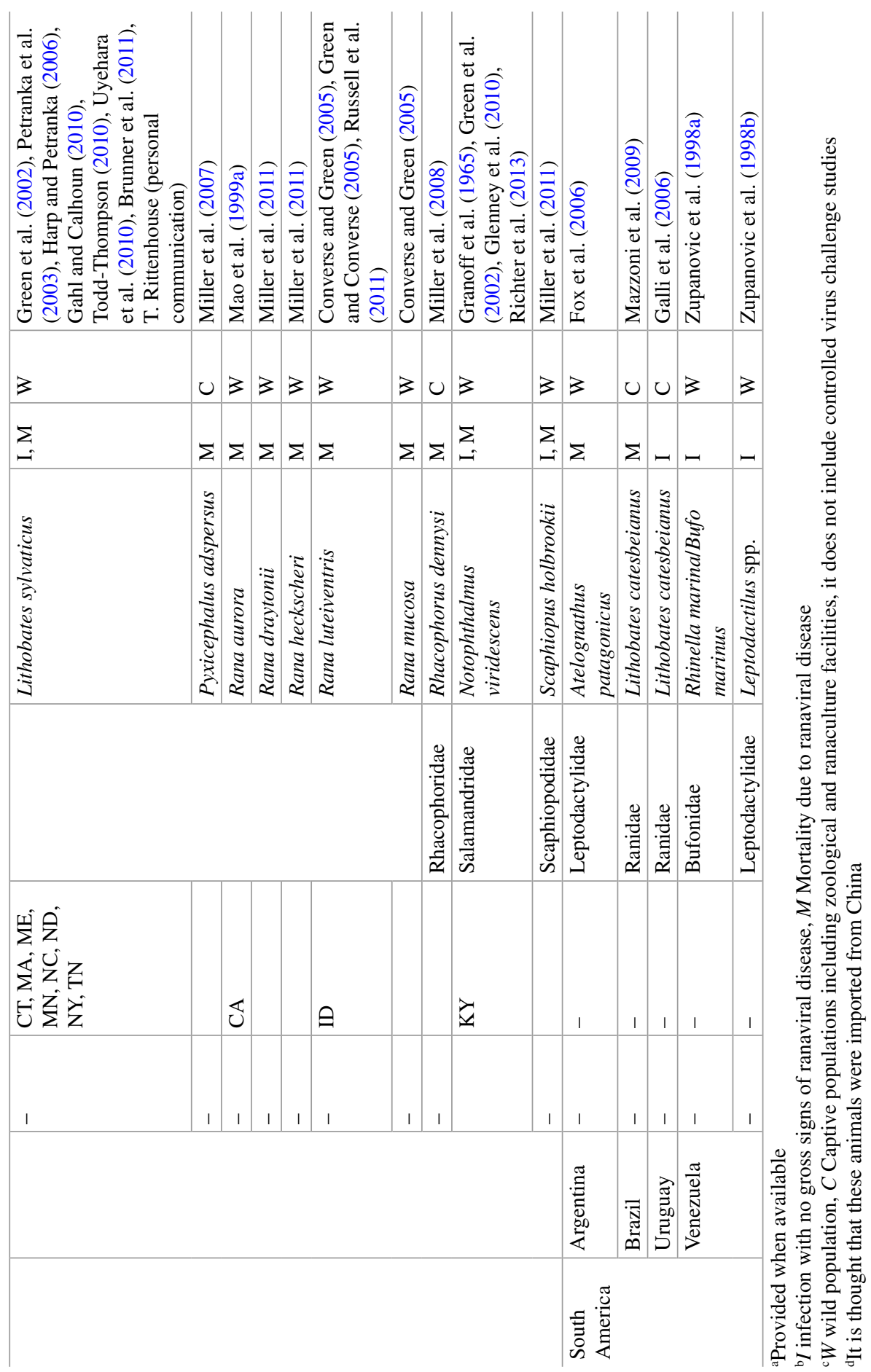




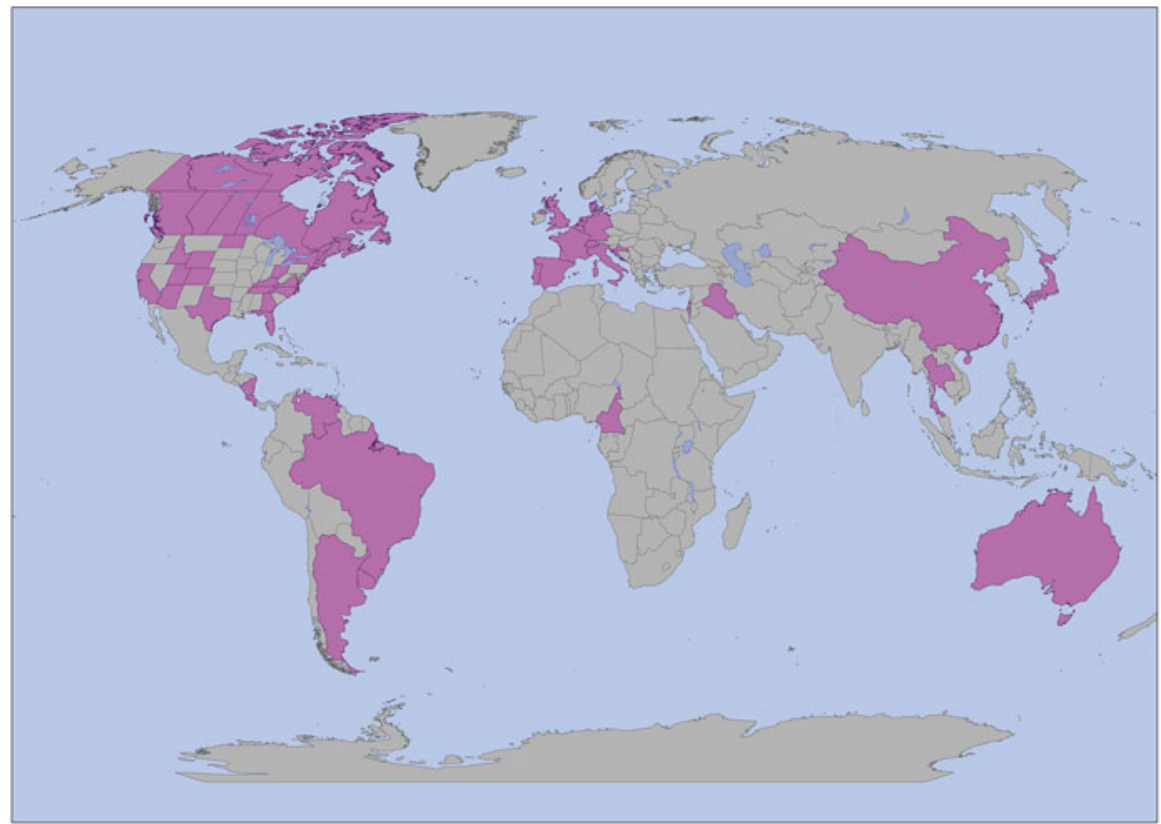

Fig. 3 Distribution of ranavirus cases involving amphibians

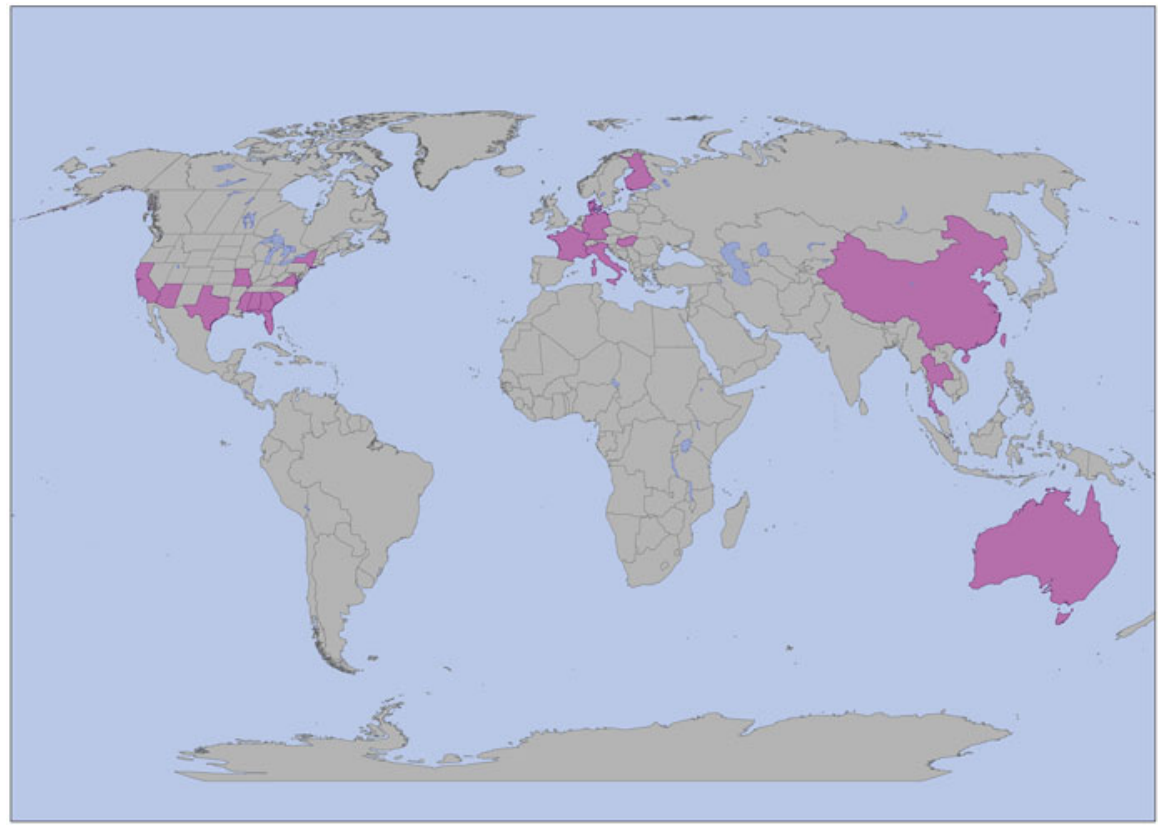

Fig. 4 Distribution of ranavirus cases involving fish 


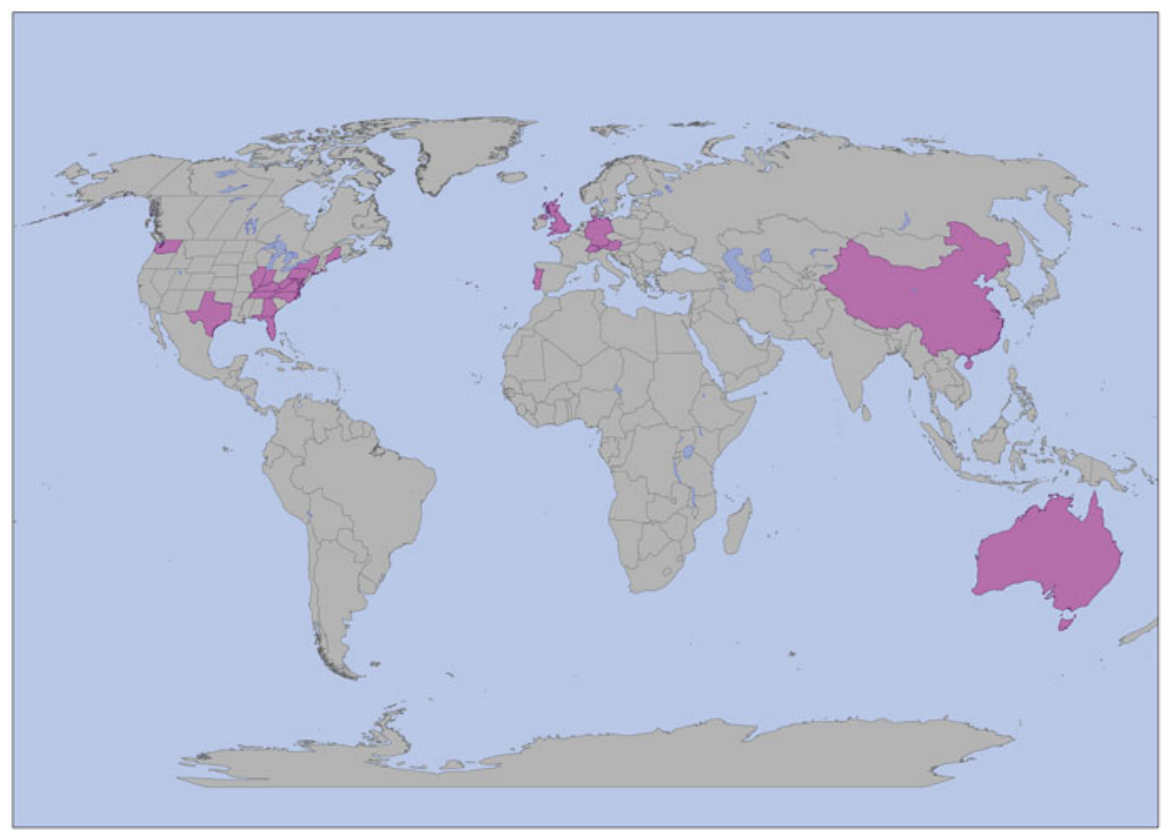

Fig. 5 Distribution of ranavirus cases involving reptiles

of ranavirus infection are not always apparent and can be confused with other factors, and mortality events are not easily observed due to their rapid progression and the fast decomposition of dead hosts (Brunner et al. 2015; Miller et al. 2015). It is perhaps not surprising that caecilians, which are fossorial and as a group poorly studied, are the only amphibian family with no reports of ranavirus infection. To our knowledge, no one has tested the susceptibility of caecilians to ranavirus or performed surveillance in wild populations.

There are three recognized species of ranaviruses that are known to infect amphibians: FV3, ATV, and BIV. Also, there are several other ranaviruses that have been isolated from amphibians (e.g., common midwife toad virus, CMTV; Balseiro et al. 2009), but are not currently recognized as ranavirus species. As discussed in Jancovich et al. (2015), declaring a given isolate as a unique viral species is complex, and compounded by the fact that there is considerable sequence conservation, often greater than $95 \%$ at the amino acid level among many ranavirus isolates. A challenge for the future is identifying genetic sequences that allow for unique characterization of ranaviruses in an evolutionary context. Below, we discuss what is known about some of the ranaviruses that infect amphibians.

\subsection{Frog Virus 3}

Since its initial isolation from the leopard frog, cases of FV3 and FV3-like infections and disease have been confirmed in a growing number of amphibian species (as well as fish and reptiles, Sects. 3 and 4). Infected animals include some that were 
visibly diseased or dying, and several cases from apparently healthy individuals. Outbreaks of FV3 and FV3-like viruses in amphibians have occurred across large sections of North America and have been found in many different species of anurans and urodeles in eastern North America. In both the USA and Canada, the number of infections caused by FV3 or FV3-like viruses is unknown, because many researchers do not report the strain of ranavirus detected in their studies. There have been no reports of ranavirus infections in Mexico, likely due to a lack of investigation. In Central America, an FV3-like ranavirus has been detected in a minimum of ten amphibian species. Specifically, in Costa Rica, at least eight species are known to have been infected with an FV3-like ranavirus (Whitfield et al. 2013), and in Nicaragua, an FV3-like ranavirus has been detected in at least two species (Stark et al. 2014). Cases of FV3 infection and disease in South America have been primarily associated with American bullfrog (L. catesbeianus) farms (Mazzoni et al. 2009), but a single case of infection in a wild amphibian population of Patagonia frogs (Atelognathus patagonicus) was reported (Fox et al. 2006).

In Europe, the first outbreaks of FV3-like viruses occurred in the southeastern UK in common frogs (Cunningham et al. 1993, 1996; Drury et al. 1995). The emergence of these viruses in common frogs was followed quickly by their emergence in common toads (Bufo bufo; Hyatt et al. 2000; Cunningham et al. 2007). Since then, FV3-like infections have been documented in common newts (Lissotriton vulgaris) and common midwife toads (Alytes obstetricans; Duffus et al. 2014). FV3-like viruses have also been detected in amphibians in continental Europe (e.g., Ariel et al. 2009; Stöhr et al. 2013c). In total, FV3-like ranaviruses have been documented in a minimum of five amphibian species in Europe.

In Asia, there have been several reports of FV3-like viruses in both wild and captive populations of amphibians. In China, an FV3-like virus was found across Heilongjiang Province in $5.7 \%$ of adult and $42.5 \%$ of larval $R$. dybowskii surveyed (Xu et al. 2010). In Japan, an FV3-like ranavirus was responsible for a mass mortality of American bullfrog tadpoles, an introduced species (Une et al. 2009a). In this case, adult bullfrogs and fish (Gnathopogon spp.) that were present in the pond did not die or appear moribund, but ranavirus was documented in the livers of the fish (Une et al. 2009b), suggesting interclass transmission. The single case of ranavirus infection in Africa reported by Docherty-Bone et al. (2013) is also likely to be an FV3-like virus. The primers used were those developed for the major capsid protein of FV3, but the PCR products were of poor quality and could not be sequenced (Docherty-Bone et al. 2013). In general, surveillance data for ranaviruses in Asia and Africa have been slower to accumulate than for North America or Europe, which are essential to understanding the distribution, host range, and threat of ranaviruses.

As mentioned, FV3 and FV3-like ranaviruses have affected many aquaculture facilities. In Japan, a ranavirus with $99 \%$ homology to the major capsid protein of FV3 was isolated from a mass mortality event in cultured Japanese clouded salamanders (Hynobius nebulosus, Une et al. 2009a). In the Americas, FV3-like viruses have also been documented in association with mass mortality events in aquaculture facilities. In the USA, FV3-like viruses have been responsible for mass mortalities 
of tadpoles and recently metamorphosed American bullfrogs in culture facilities (Majji et al. 2006; Miller et al. 2007). In Brazil, FV3-like ranaviruses have been responsible for mass mortality events at several aquaculture facilities that rear American bullfrogs (Mazzoni et al. 2009). There is some evidence that suggests that the FV3-like viruses that are present in aquaculture facilities are more virulent than those found in natural populations (Majji et al. 2006; Hoverman et al. 2010, 2011).

\subsection{Ambystoma Tigrinum Virus}

Ambystoma tigrinum virus was first described in larval Sonora tiger salamanders (Ambystoma tigrinum stebbinsi) collected from the San Rafael Valley in Arizona, USA in 1995 (Jancovich et al. 1997). This virus was isolated from a population that had both apparently healthy and visibly diseased salamander larvae (Jancovich et al. 1997). The virus that was later isolated was successfully transmitted to healthy individuals via the water, as well as through the feeding of body parts of infected animals to healthy individuals in the laboratory (Jancovich et al. 1997). After fulfilling Koch's Postulates, it was determined that ATV was the causative agent of the disease found in the tiger salamander larvae and the likely cause of recurrent epizootics first described in 1985 (Collins et al. 1988).

Ambystoma tigrinum virus in the wild appears to be restricted to western North America (Jancovich et al. 2005; Ridenhour and Storfer 2008). Phylogeographic studies of ATV strains suggest local range expansion and long-distance colonization events, which may be attributed to anthropogenic spread (Jancovich et al. 2005). ATV is found in tiger salamander larvae sold commercially as fish bait (Picco and Collins 2008), providing an anthropogenic explanation for range expansion.

Because of the potential for introduction, ATV may be a threat to naïve urodeles of conservation concern. In the lab, the endangered California tiger salamander (Ambystoma californiense) is susceptible to ATV and experienced mortality associated with infection (Picco et al. 2007). There have been no reports of ATV infections or associated mortality in wild California tiger salamanders, probably due in part to the ban on importation of non-native Ambystomatidae into the state.

Patterns of ATV infection are more similar among ponds in the same year, rather than between years (Greer et al. 2009). In natural populations of tiger salamanders located on the Kaibab Plateau in the Northern Kaibab National Forest in Arizona, outbreaks of ATV appear to be synchronous (Greer et al. 2009). Interestingly, despite four years of observation, no visible signs of disease were seen, even in cases where the infection rate in the pond was greater than $50 \%$ (Greer et al. 2009). It is thought that the lack of observed morbidity and mortality in these populations is due to coevolution between ATV and the host (Greer et al. 2009). This may be the case as there is evidence of local adaptation in ATV strains isolated from the western USA (Ridenhour and Storfer 2008). 


\subsection{Bohle Iridovirus}

Bohle iridovirus was first described in the early 1990s and was isolated from recently metamorphosed ornate burrowing frogs (Limnodynastes ornatus) in Australia that had been raised in captivity and suddenly died (Speare and Smith 1992). Using sequences from the major capsid protein, BIV was determined to be most closely related to Epizootic hematopoietic necrosis virus (EHNV), a fish ranavirus that had also been isolated in Australia (Hyatt et al. 2000). Subsequent experimentation showed that BIV was pathogenic in additional species of Australian anurans and was involved in mortality events in captive and wild settings (Cullen et al. 1995; Cullen and Owens 2002).

Until recently, BIV and BIV-like viruses were known only from Australian anurans. Then, in 2010, a BIV-like virus was isolated from boreal toads (Anaxyrus boreas boreas) held in an Iowa, USA aquarium that experienced a mass mortality. The virus, tentatively designated Zoo Ranavirus (ZRV), was found to have high sequence homology with BIV (Cheng et al. 2014). These toads had been housed with multiple species, some of which were collected in the wild from Southeast Asia, suggesting a potential route of introduction. Other species that were infected with ZRV but did not experience mortality in the outbreak included a Malayan horned frog (Megophrys nasuta) and a bumblebee toad (Melanophryniscus stelzneri, Cheng et al. 2014). At present, it is unknown whether ZRV represents a novel North American isolate of BIV, or the transmission of BIV from another captive animal.

\subsection{Other Amphibian Ranaviruses}

Common midwife toad virus (CMTV) was first isolated from common midwife toad tadpoles experiencing a mass mortality event in 2007 in northern Spain (Balseiro et al. 2009). A second mass mortality event during 2008 in the same region of Spain involving CMTV affected common midwife toad tadpoles and juvenile alpine newts (Mesotriton alpestris; Balseiro et al. 2010). A long-term study in Spain reported six amphibian species experiencing die-offs due to CMTV at several sites, with population declines documented in three species (Price et al. 2014). CMTV infections have also been found in invasive populations of American bullfrogs in Belgium (Sharifian-Fard et al. 2011), and in both captive and wild animals in the Netherlands (Kik et al. 2011, 2012). CMTV appears to be the most common ranavirus in continental Europe, but has not been found elsewhere. This virus appears to be evolutionarily unique from other ranaviruses (Mavian et al. 2012); thus, species designation may be warranted.

Another possibly unique ranavirus was isolated recently from the endangered Chinese giant salamander (Andrias davidianus; Geng et al. 2011; Chen et al. 2013; Ma et al. 2014). The virus was isolated from captive populations, and in all cases resulted in high morbidity and mortality (Geng et al. 2011; Chen et al. 2013; 
Ma et al. 2014). Phylogenetic analyses have shown that it is most closely related to CMTV (Chen et al. 2013). Dr. Lingbing Zeng has been working with several Chinese giant salamander farms, and has documented the virus across 11 Chinese provinces (L. Zeng and J. Ma, Yangtze River Fisheries Institute, unpublished data). The emergence of this ranavirus in China is a serious conservation threat (Cunningham et al. 2015).

There are several other ranaviruses that have been isolated from amphibians and named, but are not considered unique species. Rana grylio virus (RGV) was isolated in the mid-1990s in China (Zhang et al. 1996), and appears to be closely related to FV3 (Lei et al. 2012). The tiger frog virus (TFV) was isolated in 2000 from Chinese amphibians involved in a mass mortality event at a ranaculture facility (Weng et al. 2002). Both of these ranaviruses may be a threat to aquaculture facilities in Asia.

\section{Ranaviruses Infecting Fish}

Ranaviruses can cause severe systemic diseases in finfish in both marine and freshwater environments (Whittington et al. 2010). EHNV was the first ranavirus associated with fish die-offs, and was isolated in 1985 in Australia (Langdon et al. 1986b). A genetically distinct, but closely related ranavirus, European catfish virus (ECV), was detected soon after in Europe (Ahne et al. 1989). The Santee-Cooper ranavirus (SCRV), known informally as largemouth bass virus (LMBV) and currently classified by the International Committee on the Taxonomy of Viruses (ICTV) as a ranavirus, was associated with wild fish epizootics in the USA (Plumb et al. 1996). Although typically associated with morbidity in amphibians and reptiles, FV3 also has been isolated from a moribund threespine stickleback (Gasterosteus aculeatus) during a sympatric epizootic in the northern red-legged frog (Rana aurora; Mao et al. 1999a). There are three species of ranavirus recognized by the ICTV that primarily infect fish: EHNV is not known to occur naturally in any country except Australia; ECV appears to be confined to Europe; and SCRV has primarily been detected in North American fishes.

While both EHNV and ECV have impacted aquaculture (Whittington et al. 2010), BIV appears to be restricted to a single outbreak in hatchery-reared Nile tilapia fry (Oreochromis niloticus) in Australia (Ariel and Owens 1997). Recently, SCRV and FV3 have been repeatedly detected among hatchery-reared freshwater fishes in North America and Asia (Woodland et al. 2002b; Prasankok et al. 2005; Deng et al. 2011; George et al. 2014; Chinchar and Waltzek 2014; Waltzek et al. 2014). Two genetically distinct but related ranaviruses, Singapore grouper iridovirus (SGIV) and grouper iridovirus (GIV), have negatively impacted grouper mariculture in Asia since the 1990s (Chua et al. 1994; Murali et al. 2002; Qin et al. 2003). The reasons for the emergence of ranaviruses as pathogens of finfish within both natural and managed populations are unknown. However, the repeated detection of the same finfish ranaviruses (e.g., SCRV) around the globe suggests that the international movement of live 
animals and their products likely plays an important role in the occurrence of these epizootics (Hedrick and McDowell 1995; Plumb and Zilberg 1999a; Grant et al. 2005; Schramm and Davis 2006; Deng et al. 2011; George et al. 2014).

\subsection{Epizootic Haematopoietic Necrosis Virus}

The first ranavirus to be associated with systemic infection and mass mortality in any vertebrate species was EHNV. It was identified as the cause of epizootic mortality of redfin perch (Perca fluviatilis) and rainbow trout (Oncorhynchus mykiss) in Australia in 1985 (Langdon et al. 1986b, 1988; Langdon and Humphrey 1987). The source of the outbreak was not determined. A survey to detect viral infections of salmonids conducted in Australia between 1981 and 1984 did not identify any viruses (Langdon et al. 1986a), so EHNV may not have been present in trout prior to these first mortality events. Although redfin perch populations were not surveyed, there was no record of prior mass mortality (Whittington et al. 1996). To date, there have been no other known cases of EHNV mortality in the wild other than redfin perch, despite the fact that at least 14 additional species are known to be susceptible to this ranavirus according to experimental challenges (Whittington et al. 2010; Becker et al. 2013). Perhaps the difficulty of observing free-living finfish species combined with unreliable reporting of clinical disease is responsible for the current lack of EHNV detection in Australia.

The impact of EHNV on aquaculture has been limited to farmed rainbow trout in southeastern Australia; salmonid populations of Tasmania and western Australia remain free of EHNV infection. EHNV infection is endemic in wild redfin perch populations throughout southeastern Australia, excluding Tasmania. Redfin perch are highly susceptible to EHNV, while rainbow trout are relatively resistant (Whittington and Reddacliff 1995). In affected trout farms, EHNV tends to occur in only a small proportion of fish (Whittington et al. 1994, 1999), with total mortality generally $\leq 4 \%$ across all age classes. While few fish become infected, the mortality rate of infected individuals appears to be high (Whittington et al. 1994, 1999). In contrast, EHNV causes severe disease in redfin perch, affecting high proportions of populations of fingerlings and juveniles in endemic areas, and also naïve adults that enter new areas (Langdon et al. 1986b; Langdon and Humphrey 1987; Whittington et al. 1996). Anecdotal evidence suggests that redfin perch populations exposed to EHNV can recover over a few years. There is some evidence based on virus isolation and serology that both redfin perch and rainbow trout are capable of living with subclinical infections of EHNV, thus possibly function as reservoirs for the pathogen (Whittington et al. 2010).

In redfin perch, there has been progressive spread of EHNV into river systems, possibly due to natural fish migration, fish releases, and avifauna (Whittington et al. 1996). Waterborne infection and ingestion of infected fish are transmission routes of EHNV between susceptible hosts within a population, but longer distance spread is likely a result of human activity, particularly by movement of infected trout 
fingerlings in aquaculture (Langdon et al. 1988; Whittington et al. 1994, 1999). Annual outbreaks on trout farms may be due to persistence of the virus in the local environment or reinfection from wild redfin perch.

Natural epizootics in redfin perch occur most often in summer, and there is evidence of a positive relationship between EHNV pathogenicity and water temperature. Redfin perch are not susceptible to EHNV below $10^{\circ} \mathrm{C}$, and incubation periods for the virus are shorter at higher temperatures (Whittington and Reddacliff 1995). In rainbow trout, EHNV outbreaks have occurred between 11 and $20^{\circ} \mathrm{C}$ (Whittington and Reddacliff 1995; Whittington et al. 1994, 1999). Temperature-dependent pathogenicity may be related to viral replication rates (Ariel et al. 2009).

The first transmission studies with EHNV were conducted by Langdon (1989) who identified a wide range of susceptible hosts, a factor that contributed to the listing of EHNV by the International Office of Epizootics (OIE). Although there are recognized deficiencies in laboratory challenge models to determine the susceptibility of host fish to virus isolates under natural conditions, a potential increase in the host range of EHNV infections has been predicted. In three separate challenge studies, black bullhead (Ameiurus melas), pike (Esox Lucius), and pike-perch (Sander lucioperca) experienced significant mortality following bath exposure to EHNV (Bang-Jensen et al. 2009, 2011a; Gobbo et al. 2010). On the other hand, goldfish (Carassius auratus), common carp (Cyprinus carpio), and European sheatfish (Silurus glanis) did not experience significant mortality following bath exposure to EHNV (Bang-Jensen et al. 2011b; Leimbach et al. 2014). Like other ranaviruses, the outcome of EHNV infection may depend on various viral, host, and environmental factors including: virus concentration and route of delivery, viral strain, host genetics, host density and age, and water temperature (Brunner et al. 2015). For example, lower mortality was observed when European redfin perch stocks were challenged with EHNV, but it was these individuals that caused transmission of the pathogen to and extensive mortality in Australian redfin perch that were cohoused with them (Ariel and Bang-Jensen 2009).

\subsection{European Catfish Virus}

European catfish virus is the most important ranavirus that causes disease of fish in Europe. It was referred to as European sheatfish virus (ESV) prior to its formal classification. This pathogen has triggered epizootics in cultivated sheatfish in Germany (Ahne et al. 1989, 1991) and wild black bullheads in France and Italy (Pozet et al. 1992; Bovo et al. 1993; Bigarré et al. 2008). Evidently, the virus is endemic in some locations (e.g., Lake le Bourget and Lake Apremont in France; Bigarré et al. 2008). In Italy, the disease occurs in both farmed and wild black bullhead and in farmed brown bullhead (A. nebulosus), and affects production of these species (Ariel et al. 2010). An ECV outbreak was detected in brown bullheads in Hungary in 2008 (Juhász et al. 2013). 
The host range, geographic distribution, and diversity of ECV strains in Europe is incompletely understood. The virus is readily transmitted to catfish via a range of challenge methods including bath exposure, cohabitation, and intramuscular injection (Ahne et al. 1990; Pozet et al. 1992), and results in only a small proportion of exposed catfish surviving (Pozet et al. 1992). Interestingly, Gobbo et al. (2010) found different patterns of susceptibility based on closely related ranavirus strains, as black bullheads were susceptible to ECV, but not to the ESV isolate used in this study. More recent experiments have demonstrated variable pathogenicity of different isolates of ECV, and a strong impact of water temperature on disease outcome, with mortality varying between 8 and $10 \%$ among challenged sheatfish (Leimbach et al. 2014). In three separate experimental challenge studies, black bullhead, pike, and sheatfish experienced significant mortality following bath exposure to strains of ECV (Bang-Jensen et al. 2009; Gobbo et al. 2010; Leimbach et al. 2014). Goldfish, common carp, and pike-perch did not experience significant mortality following bath exposure to ECV strains (Bang-Jensen et al. 2011a, b).

\subsection{Santee-Cooper Ranavirus}

The discovery of an iridovirus from largemouth bass (Micropterus salmoides) was reported from a 1995 epizootic that occurred in the Santee-Cooper Reservoir, South Carolina, USA (Plumb et al. 1996). Accordingly, the authors named the pathogen LMBV based on the host. Subsequent genetic analyses confirmed LMBV to be a unique member of the genus Ranavirus (Mao et al. 1997, 1999b), and nearly identical to doctor fish virus (DFV) and guppy virus 6 (GV6), which had previously been isolated from imported ornamental fishes originating in Southeast Asia (Hedrick and McDowell 1995). The designation of LMBV later as SCRV was based on the location where the virus was isolated. However, Grizzle et al. (2002) disputed the change in name citing the fact that the LMBV had previously (1991) been isolated in largemouth bass from Lake Weir, Florida, USA (Francis-Floyd 1992). The aforementioned studies and more recent phylogenetic analyses support LMBV, GV6, and DFV as strains of the same species that is formally known by the ICTV as the SCRV (Holopainen et al. 2009). Importantly, it has been argued based on the genetic sequence analyses as well as epidemiological and pathobiological characteristics that SCRV may be too divergent to be included within the genus Ranavirus (Hyatt et al. 2000; Whittington et al. 2010; Jancovich et al. 2015).

Epizootics attributable to SCRV have been repeatedly reported among wild populations of North American largemouth bass (Grizzle and Brunner 2003; Plumb and Hanson 2011). Although SCRV virulence appears variable in natural and experimental settings, typical outbreaks involve adult fish observed during summer at the surface with buoyancy or equilibrium problems. In general, the factors responsible for SCRV epizootics remain unknown, and may be case-specific. However, genetic background of the largemouth bass population, SCRV exposure history within that population, SCRV strain, and environmental factors (e.g., low dissolved oxygen 
associated with warmer water temperatures) have been argued as potential factors contributing to emergence (Grizzle and Brunner 2003; Plumb and Hanson 2011). Experimental infections of SCRV in largemouth bass and striped bass (Morone saxatilis) revealed a direct correlation between virus titer and mortality by both injection and immersion; however, striped bass experienced lower overall cumulative mortality (Plumb and Zilberg 1999b; Zilberg et al. 2000). Experimental transmission of SCRV in largemouth bass via oral administration resulted in infection of the skin and internal organs (e.g., swim bladder) without mortality (Woodland et al. 2002a).

In the USA, SCRV has also been isolated from a wide range of wild asymptomatic freshwater fishes ( 6 families and 17 species) in 31 states ranging as far south as Florida to as far west as Arizona, and to the northern states of Wisconsin, Michigan, New York, Vermont, and Delaware (Goldberg 2002; Woodland et al. 2002b; Groocock et al. 2008; USFWS 2011; Iwanowicz et al. 2013; Table 3). Most recently, a SCRV strain was isolated from the exotic Northern snakehead (Channa argus) recently introduced into the Chesapeake Bay watershed (Iwanowicz et al. 2013). Asian strains of SCRV (DFV/GV6) were shown experimentally to infect and induce low mortality in rainbow trout and chinook salmon (Oncorhynchus tshawytscha), but not channel catfish (Ictalurus punctatus; Hedrick and McDowell 1995). A SCRV strain isolated from moribund hatchery-reared largemouth bass reared in China was found to be highly lethal to largemouth bass (Deng et al. 2011); however, little or no mortality was observed in seven other species tested including koi (Cyprinus carpio; Table 3). In contrast, a recent mass mortality event among farmed koi in southern India was attributed to a strain of SCRV (George et al. 2014), although the authors did not provide a detailed description of viral-induced pathology.

It seems likely that SCRV has been disseminated across the USA and globally through the unrestricted movement of live fish and their products associated with the ornamental (Hedrick and McDowell 1995; Deng et al. 2011; George et al. 2014), food (Plumb and Zilberg 1999a), and angling industries (Grant et al. 2005; Schramm and Davis 2006). For example, in the USA, largemouth bass angling tournaments may contribute to the spread of SCRV to naïve fish by placing infected and uninfected fish in close proximity; however, the stress associated with angling has not been shown to greatly increase SCRV-associated mortality (Grant et al. 2005; Schramm and Davis 2006). Given that SCRV remains infectious in frozen tissues, the import/export of frozen fish tissues may represent another mechanism by which the virus can be spread (Plumb and Zilberg 1999a). Future concerted surveillance efforts are needed to confirm the risk that the aforementioned industries play in the global dissemination of SCRV.

\subsection{Frog Virus 3}

Although only a single case of FV3 infection has been reported in wild fish (Mao et al. 1999a), a number of cases of piscine infection with FV3 have been reported among captive/cultured fish. In the former, an FV3-like virus was recovered from a 


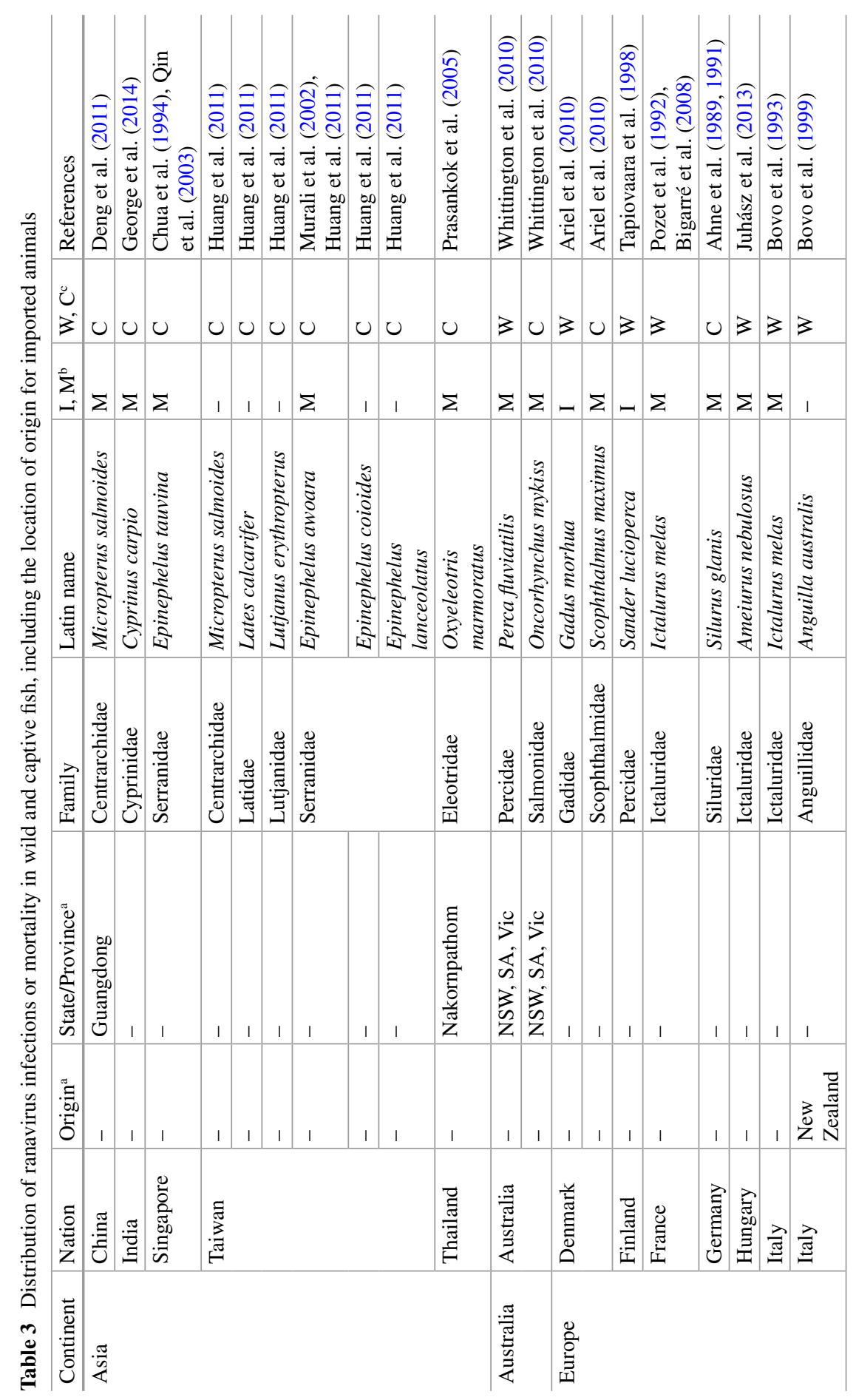




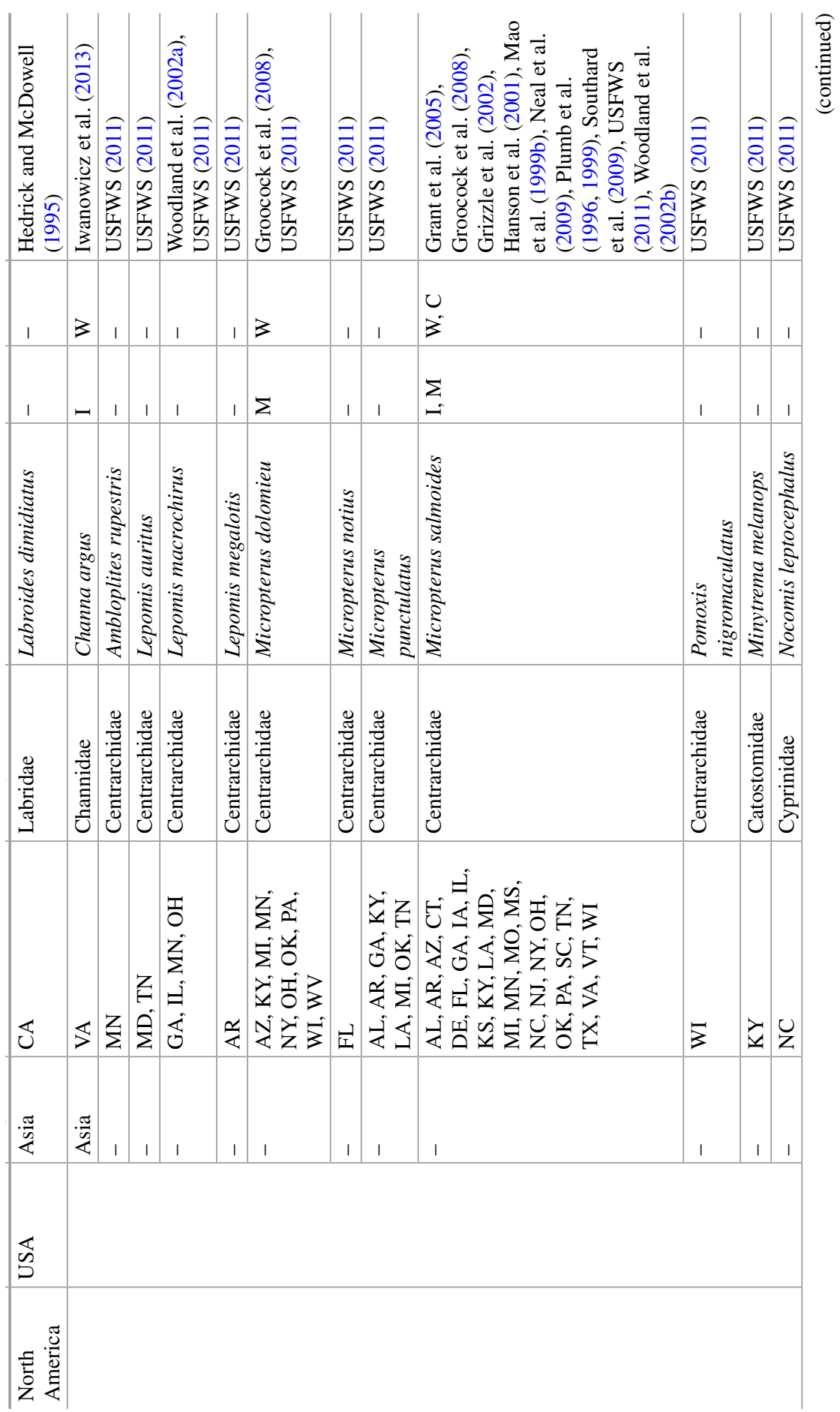




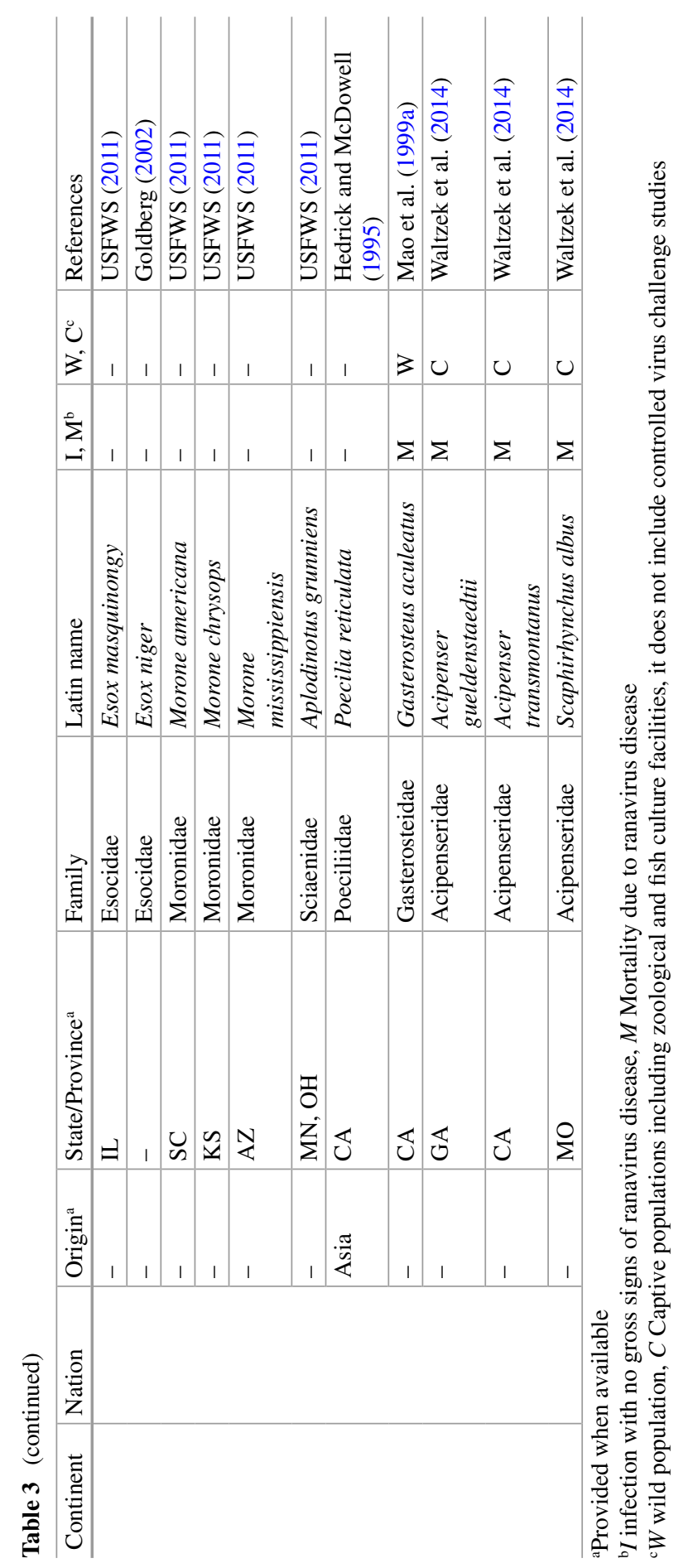


single moribund threespine stickleback that was coinfected with myxozoan parasites, obscuring the role of the virus in the disease (Mao et al. 1999a). However, FV3-like ranaviruses have been isolated from captive fishes on several occasions. A ranavirus displaying $98-99 \%$ nucleotide identity to FV3 over a portion of the major capsid gene has been reported among cultured marbled sleeper goby (Oxyeleotris marmoratus) in Thailand (Prasankok et al. 2005). Furthermore, FV3 outbreaks have impeded efforts to restore populations of the critically endangered pallid sturgeon (Scaphirhynchus albus) in the Missouri River Basin of the USA (Waltzek et al. 2014). High-mortality epizootics were reported among young-of-the-year pallid sturgeon in 2001, 2009, and 2013 at the Blind Pony Hatchery in Sweet Springs, Missouri, USA (Chinchar and Waltzek 2014; Waltzek et al. 2014). Experimental transmission of the 2009 isolate recreated the same high-mortality disease in naïve juvenile pallid sturgeon following bath exposure (Waltzek et al. 2014). Furthermore, an FV3 strain isolated from moribund hatchery-reared Russian sturgeon (Acipenser gueldenstaedtii) was found to be lethal to both Russian and lake (A. fluvescens) sturgeon following intraperitoneal injection (Waltzek et al. 2014). Finally, an FV3-like ranavirus was isolated from juvenile white sturgeon (A. transmontanus) on a California, USA, farm during an unusual mortality event in 1998 (Waltzek et al. 2014).

Experimental transmission studies using FV3-like viruses isolated from a diversity of ectothermic vertebrate classes have been shown to infect black bullhead (Ameiurus melas), northern pike, pike-perch, mosquito fish (Gambusia affinis), and bluegill (Lepomis macrochirus), although little or no mortality was observed in these species (Gobbo et al. 2010; Bang-Jensen et al. 2009, 2011a, b; Brenes et al. 2014a). Similarly, recent North American fish health surveys resulted in the isolation of FV3 from healthy appearing fathead minnow (Pimephales promelas), walleye (Sander vitreus), and northern pike (Waltzek et al. 2014). Although preliminary, these data suggest that imperiled sturgeon may be predisposed to infections with FV3-like viruses; whereas, other fishes may simply act as viral carriers or dead-end hosts. Future studies are needed to explore the importance of FV3-like viruses across a wider range of wild and captive fish species as well as the potential role of aquaculture in the global dissemination of these important pathogens.

\subsection{Bohle Iridovirus}

As indicated above, BIV was first isolated from diseased ornate burrowing frog tadpoles (Limnodynastes ornatus) in Australia. Although designated as a distinct species by the ICTV, the sequence of the MCP gene is $97.8 \%$ identical to that of EHNV, which is endemic in a different part of the continent (Marsh et al. 2002). As with FV3, laboratory challenge studies demonstrated that BIV is also pathogenic to fish, in this case to barramundi (Lates calcarifer), a popular sport fish in Australia (Moody and Owens 1994). On just one occasion, BIV may have been associated with high mortality in hatchery-reared Nile tilapia fry in Australia (Ariel and Owens 1997). Although the authors did not genetically characterize the iridovirus, feeding 
the moribund tilapia fry to barramundi fingerlings reproduced disease similar to what had been reported following challenge studies of barramundi to BIV (Moody and Owens 1994).

\subsection{Taxonomically Unassigned Ranaviruses That Affect Fish}

Although ranaviruses infecting freshwater fishes are relatively well characterized, less is known about the significance of ranaviruses infecting cultured or feral populations of marine fishes. Exceptions include two related ranaviruses, SGIV and GIV, which significantly impact grouper mariculture in Asia (Chua et al. 1994; Murali et al. 2002; Qin et al. 2003). Phylogenetic analysis based on the 26 conserved iridovirus genes demonstrated that GIV and SGIV are each other's closest relatives; however, these viruses are genetically divergent from other ranaviruses (Eaton et al. 2007). Therefore, GIV/SGIV may need to be considered as a new genus within the family Iridoviridae (Jancovich et al. 2015).

SGIV was first identified following a mass mortality event of net-cage farmed brown-spotted grouper (Epinephelus tauvina) in Singapore in 1994 (Chua et al. 1994). The authors referred to the epizootic as Sleepy Grouper Disease; however, they failed to isolate or genetically characterize the virus. In 1998, the same disease was again observed in Singapore farms following imports of brown-spotted grouper fry from Taiwan (Qin et al. 2003). These authors genetically characterized the virus as a novel ranavirus, and named it SGIV (Qin et al. 2003). Similarly, GIV has negatively impacted production of yellow grouper (Epinephelus awoara) in Taiwan (Murali et al. 2002). Delivery of the virus to yellow grouper by injection resulted in $100 \%$ mortality during experimental challenges (Murali et al. 2002). A recent study reported the isolation of SGIV and GIV strains from grouper and non-grouper species cultured in Taiwan (Huang et al. 2011, Table 3). This study illustrates the apparent expanding host range of SGIV/GIV including the first isolation of these viruses in freshwater (largemouth bass) and catadromous (barramundi) fishes.

Other partially characterized ranaviruses from wild marine fishes include cod ranavirus (CoIV) isolated from Danish Atlantic cod (Gadus morhua; Ariel et al. 2010) and the short-finned eel ranavirus (SERV) isolated from short-finned eel (Anguilla australis) off the coast of New Zealand (Bang-Jensen et al. 2009). Ranaviruses isolated from seemingly healthy cultivated freshwater and marine fishes include the pike-perch iridovirus (PPIV) isolated from Finnish pike-perch fingerlings (Tapiovaara et al. 1998) and Ranavirus maxima (Rmax) isolated from Danish turbot (Scophthalmus maximus) fry (Ariel et al. 2010). Preliminary phylogenetic analyses of these fish viruses have revealed they represent previously unknown ranaviruses, warranting more comprehensive study into their biology and potential impact on cultivated and wild populations (Holopainen et al. 2009; Jancovich et al. 2015). 


\section{Ranaviruses Infecting Reptiles}

Although ranaviral disease has been described in reptiles in a number of cases, it is likely that these disease events are underreported (Daszak et al. 1999; Johnson et al. 2010; Allender 2012) due to lack of awareness, few long-term research studies, and lack of disease monitoring in biological studies. It is notable that reports of ranavirus infections in reptiles have markedly accelerated over the past decade. The rising awareness of these viruses in chelonians as important infectious agents may have contributed to the high number of case reports in these species as well as increasing the awareness of these viruses as pathogens in reptiles in general (Shaver 2012). It has also been surmised that the global trade of reptiles and amphibians in combination with the wide host range of ranaviruses is contributing to its emergence (Stöhr et al. 2013a). This is of significant importance for wild and captive reptiles as well as amphibians and fish.

There is an increasing amount of information available on ranaviruses capable of infecting reptiles. The majority of ranaviruses detected in reptiles so far have been FV3-like (Huang et al. 2009; Allender et al. 2011). In addition, ECV-, BIV-, and CMTV-like viruses have been detected in several reptile species in captivity (Marschang et al. 2013; Stöhr et al. 2015). Characterization of these viruses has most often been based on partial MCP gene sequences, but additional sequence data are becoming available to help understand relationships between the ranaviruses found in reptiles. In the USA, only FV3-like viruses have been detected in reptiles so far, which is the most commonly reported ranavirus for anurans. In Europe, a wider range of ranavirus types has been described, including both FV3-like viruses as well as ECV, BIV, and CMTV representatives. A fully sequenced ranavirus from chelonians in Asia (soft-shelled turtle iridovirus, STIV) has been shown to be closely related to FV3 (Huang et al. 2009).

\subsection{History of Reptile Cases}

In the 1980s, two cases of iridovirus infections in tortoises were described in Switzerland (Heldstab and Bestetti 1982; Müller et al. 1988). Due to the described clinical, histological, and electronmicroscopical findings, these animals are believed to have been infected with a ranavirus and are therefore the first documented cases of ranaviral infection and disease in reptiles. A low number of proven detections of ranavirus infection in reptiles were documented in captive and wild chelonians in the late 1990s (Table 4). The first cases of ranavirus infections in reptiles from which data were available on the viral genome were from a box turtle (Terrapene $c$. carolina) and a tortoise (Testudo horsfieldii) from North America. Both appeared to be FV3-like based on partial MCP gene sequences and restriction endonuclease analysis (Mao et al. 1997). No clinical information on those two chelonians was 


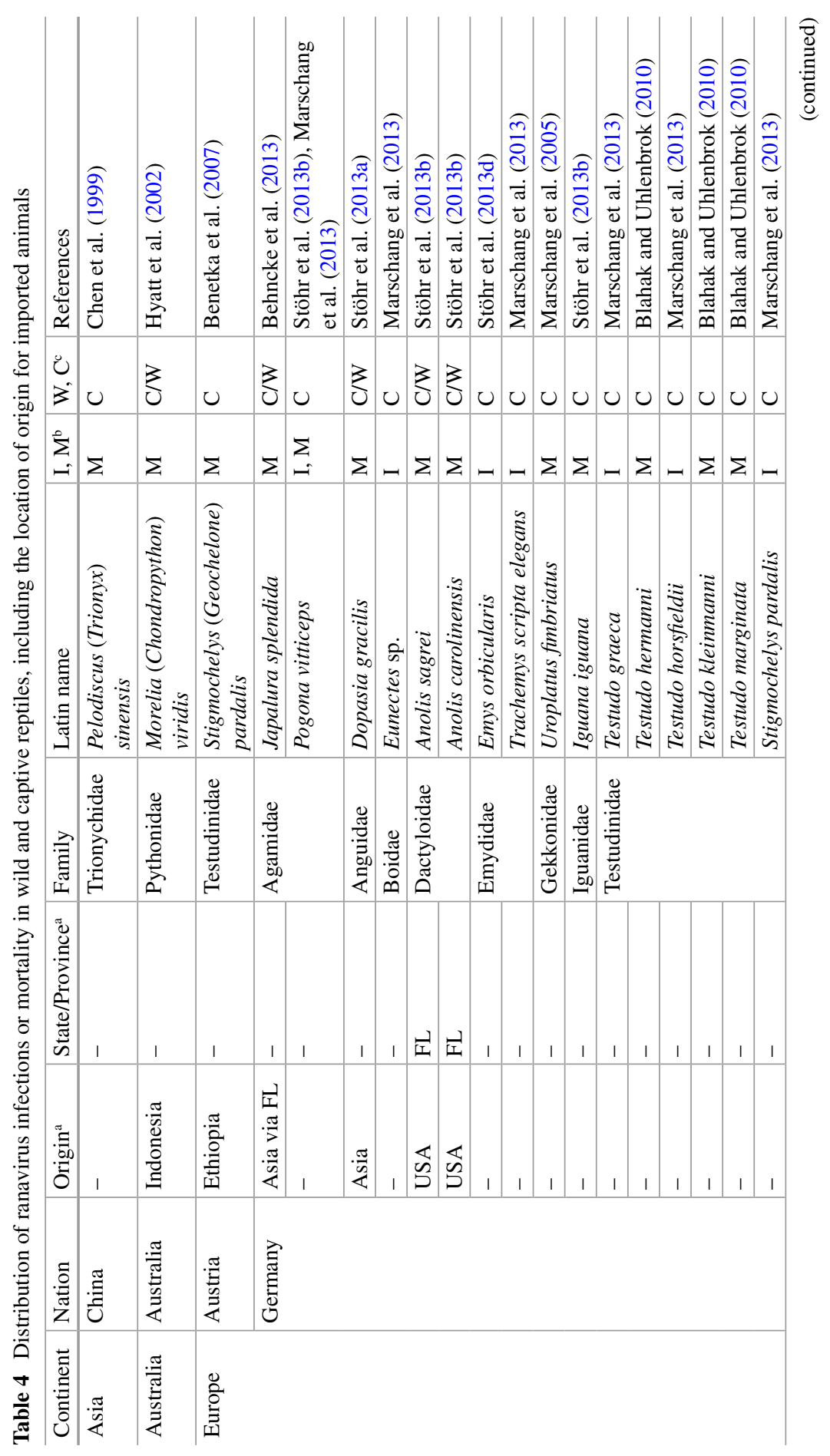




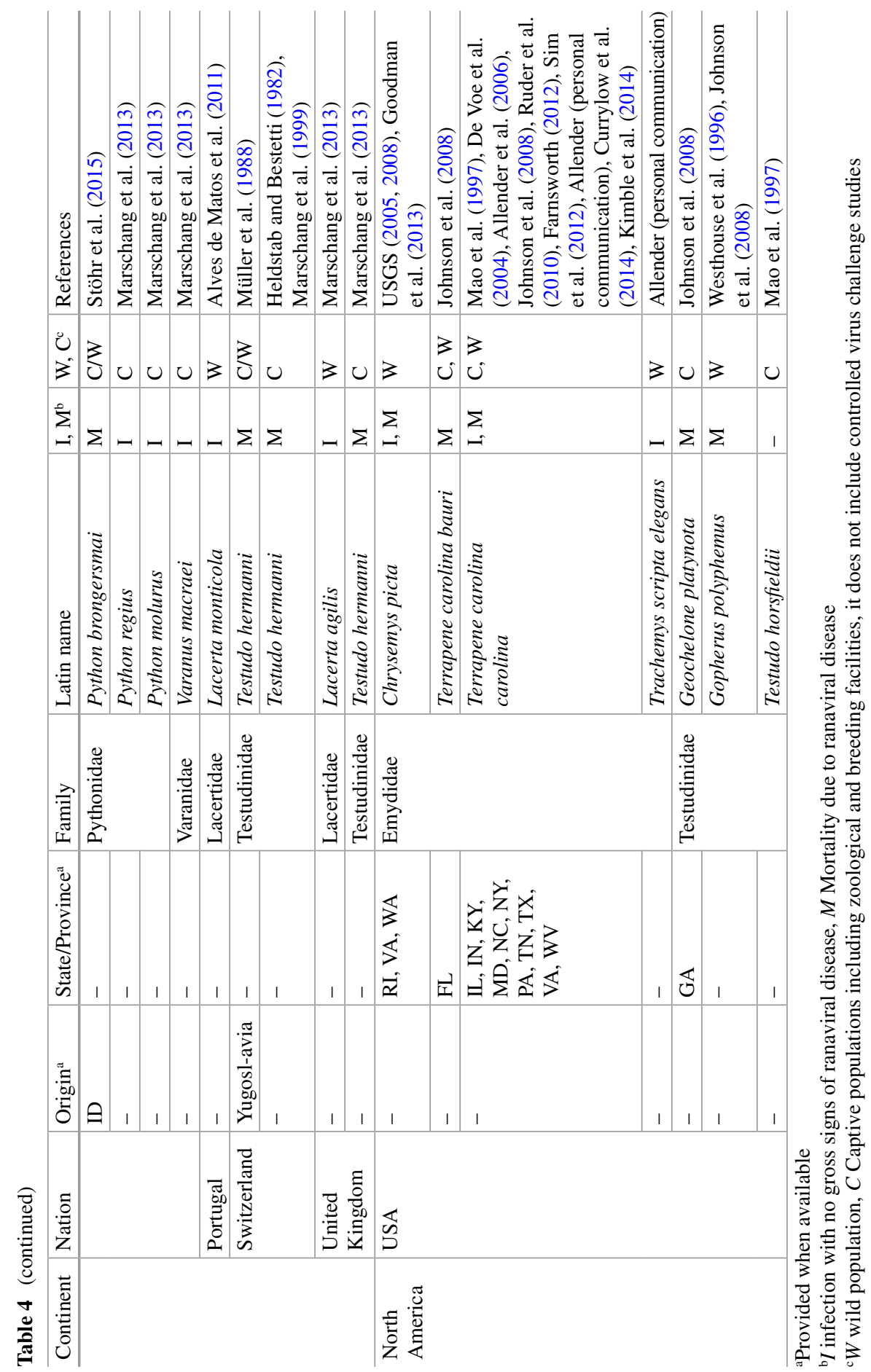


published. Recently, there has been an increase in the number of reports and cases in chelonians worldwide, especially box turtles (Terrapene sp.) in the USA (De Voe et al. 2004; Allender et al. 2006; Johnson et al. 2008; Allender 2012, Table 4). Although ranavirus detection in chelonians has been reported most frequently, detection of these viruses in lizards and snakes has been increasing, mostly from captive populations (Stöhr et al. 2013b; Behncke et al. 2013; Marschang et al. 2013). The causes for increased detection of ranaviruses in wild and captive reptiles may include increased awareness or surveillance, improved testing methods, or actual emergence of the pathogen.

\subsection{Outbreaks in Chelonians}

Adult chelonians have been more commonly reported to develop FV3-like infections than juveniles (Johnson 2006). However, recent surveillance in eastern box turtles demonstrated that juveniles are more likely to be FV3 positive (Allender 2012). Therefore, it is likely that susceptibility of chelonians to ranaviruses differs among developmental stages similar to amphibians (Haislip et al. 2011). Some outbreaks in box turtles have involved translocation events that congregate many individuals, resulting in high infection prevalence and death (Belzer and Seibert 2011; Farnsworth and Seigel 2013; Kimble et al. 2014). In a multiyear survey of box turtles in the USA, ranavirus prevalence has not been reported above $5 \%$ in a population without abnormal mortality events (Allender et al. 2013).

Reports of single cases and outbreaks in reptiles so far have mainly involved box turtles within North America (De Voe et al. 2004; Allender et al. 2006; Johnson et al. 2008, 2010; Ruder et al. 2010; Allender 2012; Kimble et al. 2014). While eastern box turtles are primarily terrestrial, they have been shown to spend a considerable amount of time in temporary ponds (Donaldson and Echternacht 2005), which may expose them to ranavirus through water or sympatric amphibians (Belzer and Seibert 2011; Currylow et al. 2014). Some studies have indicated that increased ranaviral mortality in box turtles may correlate with increased exposure to infected sympatric amphibians, possibly via predation on infected amphibians, exposure to water containing ranavirus shed by amphibians, or via hematophagous insects (Belzer and Seibert 2011; Kimble et al. 2014). A study of wild Eastern painted turtles, an aquatic species, in Virginia, USA, reported infection prevalence of 4.8 $31.6 \%$ in different ponds, with no apparent disease (Goodman et al. 2013).

Koch's postulates have been fulfilled for ranaviral disease in chelonians, including box turtles. Experimental challenge with FV3-like isolates from either Burmese star tortoises (Geochelone platynota) or eastern box turtles has resulted in high mortality in red-eared sliders (Johnson et al. 2007; Allender 2012). Characteristic clinical signs of nasal discharge and oral plaques were seen, but were inconsistent among individuals. Mortality rate and the presence of clinical signs were observed to be significantly greater in turtles exposed at $22{ }^{\circ} \mathrm{C}$ compared to $28{ }^{\circ} \mathrm{C}$, with corresponding increased viral copy number and shorter median survival time at lower temperatures (Allender et al. 2013). 
In addition to the box turtle cases described above, several other reports of FV3like infections have been seen in captive chelonians (Marschang et al. 1999; De Voe et al. 2004; Benetka et al. 2007; Johnson et al. 2008; Blahak and Uhlenbrok 2010, Table 4). Ranavirus infections were described in two juvenile diseased Hermann's tortoises (Testudo hermanni) in Germany using PCR. All seven animals in the affected group died with similar signs (Marschang et al. 1999). The associated virus was first described as FV3-like, but has since been shown to be more closely related to CMTV (Stöhr et al. 2015). A leopard tortoise (Stigmochelys (Geochelone) pardalis pardalis) with nasal discharge, stomatitis, and lethargy had concurrent ranavirus and herpes virus infection confirmed by PCR (Benetka et al. 2007). Ranaviruses have also been detected in association with mortality events in captive Hermann's tortoises, Egyptian tortoises (T. kleinmanni), and marginated tortoises ( $T$. marginata) in Germany. Affected animals developed stomatitis as well as splenic necrosis, enteritis, hepatitis, pancreatitis, and dermatitis in some cases (Blahak and Uhlenbrok 2010). Analysis of the genomes of the viruses associated with these outbreaks (tortoise ranavirus 1 and 2, ToRV-1 and-2) shows that sequence analysis clusters them closely with FV3, while their genomic arrangement resembles that of CMTV (Stöhr et al. 2015). Captive farmed soft-shelled turtles in China developed "red neck disease" associated with a ranavirus (Chen et al. 1999). Soft shell turtle iridovirus was the first reptilian ranavirus to be fully sequenced, demonstrating that it is FV3-like (Huang et al. 2009). Comparative studies of ranaviruses infecting chelonians have shown that both FV3and CMTV-like strains occur, and that strains from different outbreaks differ from one another and are often more closely related to previously described amphibian ranaviruses than to other reptile-derived ranaviruses (Stöhr et al. 2015).

The short- and long-term impacts of ranaviruses on chelonian populations are unknown. Population stability in the face of ranavirus outbreaks has been debated, particularly regarding vulnerable Eastern box turtles. Due to the low reproductive rate and long time to sexual maturation of these animals, loss of adult females due to this disease will likely lead to significant population declines over time (Farnsworth and Seigel 2013).

\subsection{Outbreaks in Squamates}

Until recently, ranaviruses were only rarely reported in squamate reptiles (snakes and lizards). The first report of ranaviruses in these animals was in a group of ten juvenile green tree pythons (Morelia (Chondropython) viridis) imported into Australia from Papua New Guinea with oral and hepatic lesions. A ranavirus that was $97 \%$ homologous to FV3 was isolated from pooled necropsy tissues (Hyatt et al. 2002). An FV3-like ranavirus was isolated from several organs of a red blood python (Python brongersmai) with similar pathology imported into Germany from Indonesia. The isolated ranavirus was most closely related to TFV, originally described in China (Stöhr et al. 2015). A leaf-tailed gecko (Uroplatus fimbriatus) died unexpectedly and was diagnosed with a BIV-like ranavirus infection 
(Marschang et al. 2005, Stöhr et al. 2015). In Portugal, a ranavirus was isolated from a wild-caught Iberian mountain lizard (Lacerta monticola) that did not show any clinical signs of disease. This isolate was closely related to FV3; a coinfection with erythrocytic necrosis virus was also found (Alves de Matos et al. 2011). In a study describing virological screening of samples from lizards (Stöhr et al. 2013b), ranaviral infections were detected in five species: brown anoles (Anolis sagrei), Asian glass lizards (Dopasia gracilis), green anoles (Anolis carolinensis), green iguanas (Iguana iguana), and a central bearded dragon (Pogona vitticeps). All of the infected lizards had skin lesions. Sequencing part of the MCP gene of each virus showed that the five detected viruses were distinct from one another and were 98.4$100 \%$ identical to the corresponding portion of the FV3 genome. However, the ranavirus detected in the green iguana was $100 \%$ identical to ECV, whereas the ranavirus found in the bearded dragon was identical to a ranavirus detected in tortoises in Germany (ToRV-1), which is most closely related to FV3 (Stöhr et al. 2015). Further analysis of the genomes of the isolated viruses demonstrated that the ranaviruses detected in anoles were closely related to FV3, whereas the isolate from the Asian glass lizard clustered phylogenetically to TFV (Stöhr et al. 2015). A ranavirus was also detected in green striped tree dragons (Japalura splendida) imported from southwestern China via Florida into Germany during a mass mortality event. The ranavirus appeared to be closely related to FV3 (Behncke et al. 2013). During a study in Germany, different reptilian samples submitted for virological testing were screened for the presence of ranavirus, with an increasing number of infections detected from 2010 to 2013. Affected species included various chelonian and squamate species (Table 4). Some of the detected ranaviruses were most closely related to $\mathrm{ECV}$, others clustered together with the previously detected ranaviruses in European amphibians or reptiles, and one virus was FV3-like (A. Stöhr, unpublished data). This increase in detection of ranaviruses in reptiles may reflect either true emergence of these viruses in reptiles or increased surveillance. The genomic differences found in the viruses studied indicate that there is not a single strain of ranavirus that has adapted to reptiles as hosts, but rather that multiple transmissions of ranaviruses from amphibians and fish to reptiles may have taken place (Jancovich et al. 2010), and may continue to occur. Interestingly, studies have shown that within the legal international trade of reptiles, the largest numbers are traded through Europe and that these include both captive bred and wild-caught animals (Bush et al. 2013). The majority of reptile infections with genetically diverse ranaviruses have also been reported in Europe, often with a connection to the pet trade (Stöhr et al. 2013b; Stöhr et al. 2015). The role of illegal trade in exotic pets for the epidemiology of ranaviral infections in reptiles has not been studied, although there is some indication that this has played a role in ranaviral outbreaks in pet reptiles as well (S. Blahak, CVUA-OWL, personal communication). Wild-caught and farmed reptiles that are globally traded are often in contact with other animal species (reptiles and amphibians), and are not regularly tested for the presence of infections. Another aspect of increased surveillance and reporting of ranaviral infections in reptiles is the increased finding of co-infections with other pathogens, making diagnosis of ranaviral disease in some cases difficult. 


\section{$5 \quad$ Interclass Transmission of Ranaviruses}

Ranaviruses, as described above, are pathogens that affect a wide variety of hosts across three classes of ectothermic vertebrates (Amphibia, Reptilia, and Osteichthyes). It has long been suspected that interclass transmission of this group of viruses was possible, but it has only recently been demonstrated experimentally under controlled laboratory conditions (Brenes et al. 2014a). Evidence exists that interclass transmission may occur in wild populations for at least BIV, ATV, and FV3.

The first evidence for interclass transmission of ranaviruses was provided by Moody and Owens (1994). Barramundi (Lates calcarifer) were exposed to BIV, an isolate derived from amphibians, by water bath exposure or injection. The exposed fish developed disease and experienced $100 \%$ mortality (Moody and Owens 1994). BIV has also successfully been transmitted to juvenile short-necked turtles (Emydura macquarii krefftii) and saw-shelled turtles (Myuchelys (Elseya) latisternum), but adult turtles of the same species as well as juvenile crocodiles (Crocodylus johnstoni) were not successfully infected. Transmission studies with three species of snakes (brown tree snakes, Boiga irregularis, common green tree snakes, Dendrelaphis punctulatus, and keelback snakes, Tropidonophis (Amphiesma) mairii) did not induce disease in any of the animals, but BIV was reisolated from one of the brown tree snakes four weeks after inoculation (Ariel 1997). The isolation of BIV so long after initial infection without clinical signs suggests that this species may be a viable reservoir (Ariel 1997).

Although originally thought to be restricted to urodeles (Jancovich et al. 2001), ATV was later shown to be pathogenic to anurans (Schock et al. 2008). Experimental infection of largemouth bass was successful, but inoculated animals experienced no mortality or disease (Picco et al. 2010). There is also evidence that multiple FV3like and ATV-like strains may circulate in ponds and may affect both urodeles and anurans (Schock et al. 2008). To date, no experimental infections of ATV in reptiles have been attempted.

An additional study by Bayley et al. (2013) has shown that a ranavirus originally isolated from fish (PPIV) is capable of causing mortality in common frog tadpoles. Common frog tadpoles were exposed to a panel of six fish-derived ranavirus isolates via water bath. However, only one of the six ranavirus isolates, PPIV, caused mortality. This was the first case where exposure to a fish-derived isolate caused death in an amphibian. Subsequent experiments by Brenes et al. (2014a) have shown transmission of an FV3-like isolate from fish to amphibians.

FV3-like viruses have been detected in fish, amphibians, and reptiles and there is evidence from wild populations, captive settings, and from experimental transmission studies that these viruses have a very wide host range. Mao et al. (1999a) found identical ranavirus isolates from a threespine stickleback and a northern red-legged frog (Rana aurora) tadpole from the same area. FV3-like viruses have been isolated from moribund marbled sleeper gobies (Oxyeleotris marmoratus) cultivated in Thailand (Prasankok et al. 2005) and several hatchery-reared sturgeon species during epizootics in the USA (Waltzek et al. 2014); however, the role of the virus in disease was only thoroughly studied and confirmed in pallid sturgeon. 
Brenes et al. (2014a) demonstrated water-bath transmission of an FV3-like virus, originally isolated from a moribund pallid sturgeon to amphibians (Cope's gray treefrog, Hyla chrysoscelis), fish (mosquito fish) and reptiles (red-eared sliders). In a similar experiment, three chelonians (Florida soft-shelled turtle, Apalone ferox; eastern river cooters, Pseudemys concinna; Mississippi map turtles, Graptemys pseudogeographica kohnii) were assessed for susceptibility to the same FV3-like virus, an FV3-like isolate from an eastern box turtle and a third FV3-like isolate from an American bullfrog, from the USA (Brenes et al. 2014b). While no disease or mortality was observed in these experiments, infections were documented in soft-shelled turtles that were exposed to the fish isolate and those that were exposed to the turtle isolate (Brenes et al. 2014b). Infections were also observed in the Mississippi map turtles that were exposed to the turtle isolate (Brenes et al. 2014b). These results demonstrate the possibility that reptiles, fish, and amphibians may act as reservoirs for FV3-like ranaviruses for other taxa.

The role of different host classes in the epidemiology of ranaviruses remains to be studied. A number of field studies have indicated that ranavirus infections in one group of hosts can affect the health and survival of sympatric ectothermic vertebrates, but the role of various hosts as long-term carriers of virus and in the dynamics of transmission is yet unknown. The fact that several studies have shown that different viruses may have vastly different effects on various hosts is also important for the assessment of infection status in clinically healthy animals, both in the wild and in captivity, especially in trade. Healthy infected animals in which ranaviruses are not suspected could be a source of infection via direct contact or environmental contamination for other susceptible species of other animal classes. All of these findings underscore the need to reassess our understanding of ranaviruses as multispecies pathogens, not only as pathogens of specific groups of animals.

\section{Summary and Conclusions}

Ranavirus infections in amphibians, fish, and reptiles are widespread and affect a diverse suite of species within these vertebrate classes (Table 1, Fig. 6). The species affected include some that are economically important (e.g., rainbow trout, softshelled turtle, bullfrogs), but also several that are of conservation concern (e.g., Chinese giant salamander, gopher tortoise, dusky gopher frog, pallid sturgeon). The economic and conservation risk of these multispecies pathogens is dependent upon many factors, including characteristics of the host species. One thing is certain - some host species are highly susceptible to ranavirus, and these species are most likely to be affected during outbreaks. Thus, understanding host susceptibility to different ranaviruses is key to quantifying risk. Host-pathogen interactions between ranaviruses and amphibians are the best characterized. Research in this area needs to continue, but there also needs to be greater attention on the role of reptiles and fish in ranavirus epizootic events. 

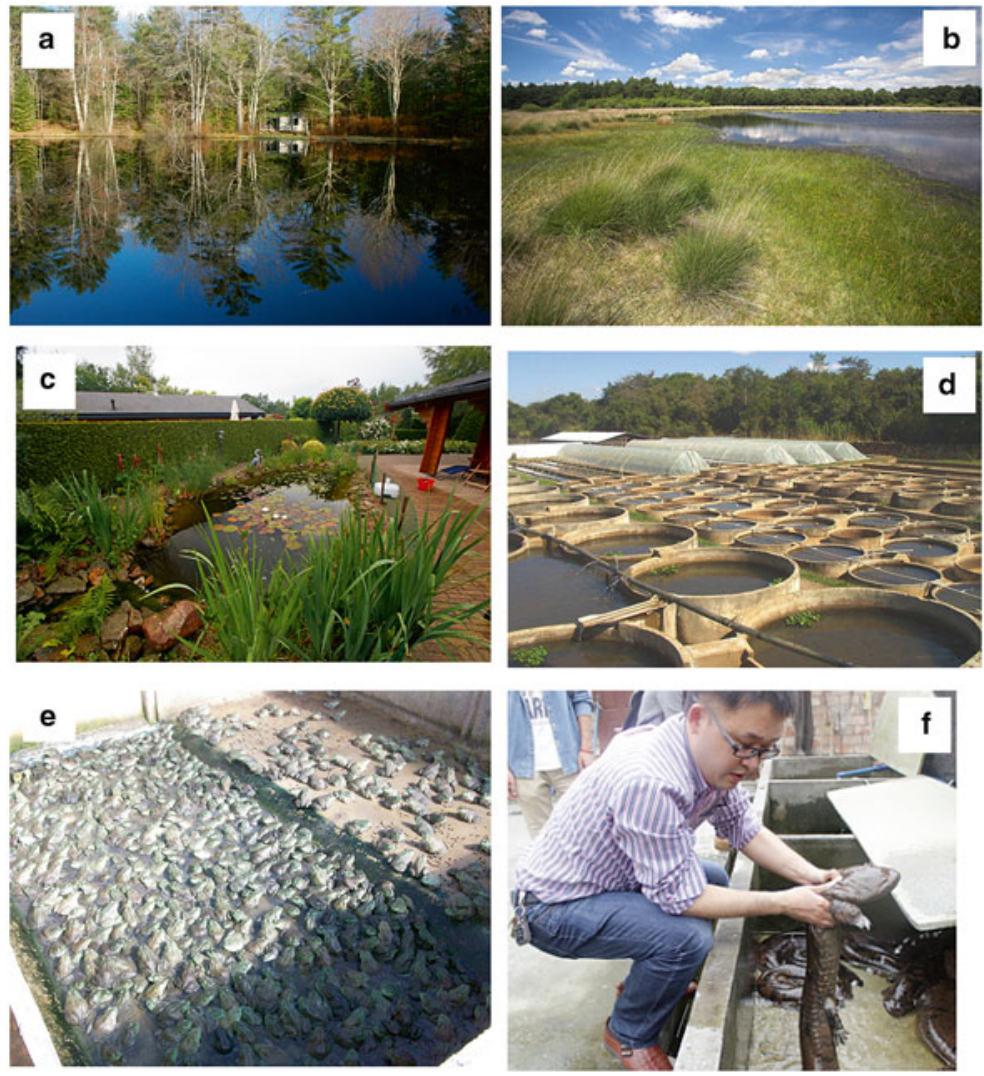

Fig. 6 Sites of ranavirus outbreaks include seemingly undisturbed sites, such as (a) Maine, USA (credit $=$ Nathaniel Wheelwright $)$ and $(\mathbf{b})$ Dwingelderveld, Netherlands (credit $=$ Jeiger Herder $),(\mathbf{c})$ constructed ponds in urban environments (credit $=$ Jeiger Herder), and $(\mathbf{d})$ aquaculture facilities (credit=Rolando Mazzoni). High host density and environmental stressors likely contribute to outbreaks, especially in captive facilities (e.g., (e) bullfrog farm in Brazil; credit=Rolando Mazzoni). Some highly endangered species (e.g., Andrias davidianus) have been affected (f), credit $=$ Yi Geng

All three classes of vertebrate hosts are intensively farmed in different regions of the world. The conditions of captive culture facilities that often maintain high densities of genetically similar individuals may be conducive to repeated outbreaks of ranaviral disease (Pearman and Garner 2005; Fig. 6). Additionally, conditions that favor transmission can lead to increased virulence, according to the virulence tradeoff hypothesis (Alizon et al. 2009). Thus, captive facilities with recurring ranavirus outbreaks may facilitate evolution of ranavirus types that are more virulent than wild types (Brunner et al. 2015). 
The commercial trade of ranavirus hosts is likely a significant factor facilitating the global distribution of ranaviruses, as well as interclass transmission of the pathogen. If novel strains of ranaviruses are introduced into naïve populations, experimental evidence suggests that there could be devastating effects (e.g., Pearman et al. 2004; Storfer et al. 2007; Hoverman et al. 2010). With the trade in animals being truly global and ranaviruses accompanying them (e.g., Schloegel et al. 2009; Kolby et al. 2014), it is important to understand what ranaviruses are being transported and where they end up.

Understanding the geographical distribution and host range of ranaviruses is becoming increasingly important as the World Health Organization for Animals has declared that EHNV and ranaviruses that infect amphibians are "reportable infections of wildlife" (OIE 2008). This designation requires countries that have agreed to OIE policies to screen a sample of ranavirus hosts that are crossing international borders for the presence of ranaviruses (Schloegel et al. 2010). However, few countries have yet taken steps to implement import policies that require declaration of ranavirus-free animals. Moreover, infection of fish by ranaviruses (other than EHNV) and reptiles (for any ranavirus species) are not included in the OIE regulations.

We are just beginning to understand the distribution and host range of ranaviruses. Continued surveillance of wild and captive populations, as well as, commercially traded animals combined with the characterization of the ranavirus strains are necessary to fully understand the distribution and host diversity of ranaviruses. Therefore, when ranavirus studies are undertaken, sufficient funding should be obtained to at least partially characterize the virus if detected. This approach will require that researchers work in interdisciplinary groups.

Acknowledgments Funding has been provided by a President's Initiative Faculty Development Grant Type A to ALJD.

The authors would like to thank Jesse Brunner (Washington State University) and two anonymous referees for their comments on previous versions of this manuscript.

Open Access publication was made possible through grants provided by the University of Tennessee (Institute of Agriculture, Office of Research and Engagement, and Department of Forestry, Wildlife, and Fisheries), Washington State University Libraries, Gordon State College (Office of Academic Affairs), the Association of Reptilian and Amphibian Veterinarians, and the Amphibian and Reptile Conservancy.

Open Access This chapter is distributed under the terms of the Creative Commons Attribution Noncommercial License, which permits any noncommercial use, distribution, and reproduction in any medium, provided the original author(s) and source are credited.

\section{References}

Ahne W, Schlotfeldt HJ, Thomsen I (1989) Fish viruses: isolation of an icosahedral cytoplasmic deoxyribovirus from sheatfish (Silurus glanis). J Vet Med B 36:333-336

Ahne W, Ogawa M, Schlotfeldt HJ (1990) Fish viruses: transmission and pathogenicity of an icosahedral cytoplasmic deoxyribovirus isolated from sheatfish (Silurus glanis). J Vet Med B $37: 187-190$ 
Ahne W, Schlotfeldt HJ, Ogawa M (1991) Iridovirus infection of adult sheatfish (Silurus glanis). Bull Eur Assoc Fish Pathol 11:97-98

Alizon S, Hurford A, Mideo N et al (2009) Virulence evolution and the trade-off hypothesis: history, current state of affairs and the future. J Evol Biol 22:245-259

Allender MC (2012) Characterizing the epidemiology of ranavirus in North American chelonians: diagnosis, surveillance, pathogenesis, and treatment. Ph.D. Thesis, Department of Veterinary Clinical Medicine, University of Illinois at Urbana-Champaign, Urbana, p 219

Allender MC, Fry MM, Irizarry AR et al (2006) Intracytoplasmic inclusions in circulating leukocytes from an eastern box turtle (Terrapene carolina carolina) with iridoviral infection. J Wildl Dis 42:677-684

Allender MC, Abd-Eldaim M, Schumacher J et al (2011) PCR prevalence of ranavirus in freeranging eastern box turtles (Terrapene carolina carolina) at rehabilitation centers in three southeastern US states. J Wildl Dis 47:759-764

Allender MC, Mitchell MA, McRuer D et al (2013) Prevalence, clinical signs, and natural history characteristics of frog virus 3-like infections in eastern box turtles (Terrapene carolina carolina). Herpetol Conserv Biol 8:308-320

Alves de Matos AP, Caeiro MF, Marschang RE et al (2008) Adaptation of ranaviruses from Peneda-Gerês National Park (Portugal) to cell cultures and their characterizations. Microsc Microanal 14:139-140

Alves de Matos AP, Caeiro MF, Papp R et al (2011) New viruses from Lacerta monticola (Serra da Estrela, Portugal): further evidence for a new group of nucleo-cytoplasmic large deoxyriboviruses. Microsc Microanal 17:101-108

Ariel E (1997) Pathology and serological aspects of Bohle iridovirus infections in six selected water-associated reptiles in North Queensland. Ph.D. Thesis, Department of Microbiology and Immunology, James Cook University, North Queensland, p 168

Ariel, E. \& Bang-Jensen, B. 2009. Challenge studies of European stocks of redfin perch, Perca fluviatilis L., and rainbow trout, Oncorhynchus mykiss (Walbaum), with epizootic haematopoietic necrosis virus. Journal of Fish Diseases, 32, 1017-1025

Ariel E, Owens L (1997) Epizootic mortalities in tilapia Oreochromis mossambicus. Dis Aquat Organ 29:1-6

Ariel E, Kielgas J, Svart HE et al (2009) Ranavirus in wild edible frogs, Pelophylax kl. esculentus in Denmark. Dis Aquat Organ 85:7-14

Ariel E, Holopainen R, Olesen NJ et al (2010) Comparative study of ranavirus isolates from cod (Gadus morhua) and turbot (Psetta maxima) with reference to other ranaviruses. Arch Virol 155:1261-1271

Balseiro A, Dalton KP, Cerrol A et al (2009) Pathology, isolation and molecular characterization of a ranavirus from the common midwife toad Alytes obstetricans on the Iberian Peninsula. Dis Aquat Organ 84:95-104

Balseiro A, Dalton KP, Cerro A et al (2010) Outbreak of common midwife toad virus in alpine newts (Mesotriton alpestris cyreni) and common midwife toads (Alytes obstetricans) in northern Spain: comparative pathological study of an emerging ranavirus. Vet J 186:256-258

Bang-Jensen B, Ersboll AK, Ariel E (2009) Susceptibility of pike Esox lucius to a panel of Ranavirus isolates. Dis Aquat Organ 83:169-179

Bang-Jensen B, Holopainen R, Tapiovaara H et al (2011a) Susceptibility of pike-perch Sander lucioperca to a panel of ranavirus isolates. Aquaculture 313:24-30

Bang-Jensen B, Reschova S, Cinkova K et al (2011b) Common carp (Cyprinus carpio) and goldfish (Carassius auratus) were not susceptible to challenge with ranavirus under certain challenge conditions. Bull Eur Assoc Fish Pathol 31:112-118

Bayley AE, Hill BJ, Feist SW (2013) Susceptibility of the European common frog Rana temporaria to a panel of ranavirus isolates from fish and amphibian hosts. Dis Aquat Organ 103:171-183

Becker JA, Tweedie A, Gilligan D et al (2013) Experimental infection of Australian freshwater fish with epizootic haematopoietic necrosis virus (EHNV). J Aquat Anim Health 25:66-76

Behncke H, Stöhr AC, Heckers KO et al (2013) Mass mortality in green striped tree dragons (Japalura splendida) associated with multiple viral infections. Vet Rec 173:248 
Belzer WR, Seibert S (2011) A natural history of Ranavirus in an eastern box turtle population. Turtle Tortoise Newsl 15:18-25

Benetka V, Grabensteiner E, Gumpenberger M et al (2007) First report of an iridovirus (Genus Ranavirus) infection in a Leopard tortoise (Geochelone pardalis pardalis). Wien Tierarztl Monatsschr 94:243-248

Bigarré L, Cabon J, Baud M et al (2008) Ranaviruses associated with high mortalities in catfish in France. Bull Eur Assoc Fish Pathol 28:163-168

Blahak S, Uhlenbrok C (2010) Ranavirus infections in European terrestrial tortoises in Germany. In: Öfner S, Weinzierl F (eds) Proceedings of the 1st international conference on reptile and amphibian medicine, Munich, Germany, 4-7 March 2010, pp 17-23

Bollinger RK, Mao J, Schock DM et al (1999) Pathology, isolation, and preliminary molecular characterization of a novel iridovirus from tiger salamanders in Saskatchewan. J Wildl Dis 35:413-429

Bovo G, Comuzzi M, De Mas S et al (1993) Isolation of an irido-like viral agent from breeding cat fish (Ictalurus melas). Boll Soc It Patol Ittica 11:3-10

Bovo G, Giacometti P, Montesi F et al (1999) Isolation of an irido-like agent from New Zealand eel. In: Proceedings of the European Association of Fish Pathologists, Rhodes, Greece, p 53

Brenes R, Gray MJ, Waltzek TB et al (2014a) Transmission of ranavirus between ectothermic vertebrate hosts. PLoS One 9:e92476

Brenes R, Miller DL, Waltzek TB et al (2014b) Susceptibility of fish and turtles to three ranaviruses isolated from different ectothermic vertebrate classes. J Aquat Anim Health 26:118-126

Brunner JL, Barnet KE, Gosier CJ et al (2011) Ranavirus infection in die-offs of vernal pool amphibians in New York, USA. Herpetol Rev 42:76-79

Brunner JL, Storfer A, Gray MJ, Hoverman JT (2015) Ranavirus ecology and evolution: from epidemiology to extinction. In: Gray MJ, Chinchar VG (eds) Ranaviruses: lethal pathogens of ectothermic vertebrates. Springer, New York

Bush ER, Baker SE, MacDonald DW (2013) Global trade in exotic pets 2006-2012. Conserv Biol 28:663-676

Chen ZX, Zheng JC, Jiang YL (1999) A new iridovirus isolated from soft-shelled turtle. Virus Res 63:147-151

Chen Z, Gui X, Gao C et al (2013) Genome architecture changes and major gene variations of Andrias davidianus ranavirus (ADRV). Vet Res 44:101

Cheng K, Jones MEB, Jancovich JK et al (2014) Isolation of a Bohle iridovirus-like agent from boreal toads housed within a cosmopolitan aquarium collection. Dis Aquat Organ 111(2):139-152

Chinchar VG (2002) Ranaviruses (family Iridoviridae): emerging cold-blooded killers. Arch Virol $147: 447-470$

Chinchar VG, Waltzek TB (2014) Ranaviruses: not just for frogs. PLoS Pathog 10:e1003850

Chua FHC, Ng ML, Ng KL et al (1994) Investigation of outbreaks of a novel disease, 'Sleepy Grouper Disease', affecting the brown-spotted grouper, Epinephelus tauvina Forskal. J Fish Dis 17:417-427

Clark HF, Brennan JC, Zeigel RF et al (1968) Isolation and characterization of viruses from the kidneys of Rana pipiens with renal adenocarcinoma before and after passage in the red eft (Triturus viridescens). J Virol 2:629-640

Collins JP, Jones TR, Berna HJ (1988) Conserving genetically distinct populations: the case of the Huachuca tiger salamander (Ambystoma tigrinum stebbinsi Lowe). In: Proceedings of the symposium on management of amphibians, reptiles and small mammals in North America, Flagstaff, Arizona, 19-21 July 1988

Converse KA, Green DE (2005) Diseases of tadpoles. In: Majumadar SK, Huffman JE, Brenner FJ et al (eds) Wildlife diseases: landscape epidemiology, spatial distribution and utilization of remote sensing techniques. The Pennsylvania Academy of Science, Easton, pp 72-88

Cullen BR, Owens L (2002) Experimental challenge and clinical cases of Bohle iridovirus (BIV) in native Australian anurans. Dis Aquat Organ 49:83-92 
Cullen BR, Owens L, Whittington RJ (1995) Experimental infection of Australian anurans (Limnodynastes terraereginae and Litoria latopalmata) with Bohle iridovirus. Dis Aquat Organ 23:83-92

Cunningham AA, Langton TES, Bennett PM et al (1993) Unusual mortality associated with poxvirus-like particles in frogs (Rana temporaria). Vet Rec 133:141-142

Cunningham AA, Langton TES, Bennet PM et al (1996) Pathological and microbial findings from incidents of unusual mortality on the common frog (Rana temporaria). Philos Trans R Soc Lond B Biol Sci 315:1539-1557

Cunningham AA, Hyatt AD, Russell P et al (2007) Experimental transmission of a ranavirus disease of common toads (Bufo bufo) to common frogs (Rana temporaria). Epidemiol Infect 135:1213-1216

Cunningham AA, Turvey ST, Zhou F (2015) Development of the Chinese giant salamander Andrias davidianus farming industry in Shaanxi Province, China: conservation threats and opportunities. Oryx doi:10.1017/S0030605314000842.

Currylow AF, Johnson AJ, Williams RN (2014) Evidence of ranavirus infections among sympatric larval amphibians and box turtles. J Herpetol 48:117-121

Daszak P, Berger L, Cunningham AA et al (1999) Emerging infectious diseases and amphibian population declines. Emerg Infect Dis 6:735-748

Davidson SRA, Chambers DL (2011) Ranavirus prevalence in amphibian populations of Wise County, Virginia, USA. Herpetol Rev 42:214-215

De Voe RK, Geissler K, Elmore S et al (2004) Ranavirus-associated morbidity and mortality in a group of captive eastern box turtles (Terrapene carolina carolina). J Zoo Wildl Med 35:534-543

Deng G, Li S, Xie J, Bai J et al (2011) Characterization of a ranavirus isolated from cultured largemouth bass (Micropterus salmoides) in China. Aquaculture 312:198-204

Docherty DE, Meteyer CU, Wang J et al (2003) Diagnostic and molecular evaluation of three iridovirus associated salamander mortality events. J Wildl Dis 39:556-566

Docherty-Bone TM, Ndifon RK, Nyingchia ON et al (2013) Morbidity and mortality of the critically endangered Lake Oku clawed frog (Xenopus longipes). Endanger Species Res 21:115-128

Donaldson BM, Echternacht AC (2005) Aquatic habitat use relative to home range and seasonal movement of Eastern box turtles (Terrapene carolina carolina: Emydidae) in Eastern Tennessee. J Herpetol 39:278-284

Driskell EA, Miller DL, Swist SL et al (2009) PCR detection of ranavirus in adult anurans from the Louisville Zoological Gardens. J Zoo Wildl Med 40:559-563

Drury SEN, Gough RE, Cunningham AA et al (1995) Isolation of an iridovirus-like agent from common frogs (Rana temporaria). Vet Rec 137:72-73

Duffus ALJ, Cunningham AA (2010) Major disease threats to European amphibians. Herpetol J 20:117-127

Duffus ALJ, Pauli PD, Wozney K et al (2008) Frog virus 3-like infections in aquatic amphibian communities. J Wildl Dis 44:109-120

Duffus ALJ, Nichols RA, Garner TWJ (2013) Investigations into the life history stages of the common frog (Rana temporaria) affected by an amphibian ranavirus in the United Kingdom. Herpetol Rev 44:460-463

Duffus ALJ, Nichols RA, Garner TWJ, 2014. Detection off a frog virus 3-like ranavirus in native and introduced amphibians in the United Kingdom in 2007 and 2008. Herpetol Rev 45:608-610

Earl JE, Gray MJ (2014) Introduction of ranavirus to isolated wood frog populations could cause local extinction. Ecohealth. doi:10.1007/s10393-014-0950-y

Eaton HE, Metcalf J, Penny E, Tcherepanov V, Upton C, Brunetti CR (2007) Comparative genomic analysis of the family Iridoviridae: re-annotating and defining the core set of iridovirus genes. Virol J 4:11-28

Echaubard P, Little K, Pauli B, Lesbarrères D (2010) Context-dependent effects of ranaviral infection on northern leopard frog life history traits. PLoS One 5:e13723 
Farnsworth SD (2012) On-site and off-site translocations of eastern box turtles (Terrapene carolina carolina): Comparisons of survival and overwintering ecology. MSc Thesis, Department of Biological Sciences, Towson University, Towson, MD, USA. http://www.academia.edu/5781810/ ON-SITE_AND_OFF-SITE_TRANSLOCATIONS_OF_EASTERN_BOX_TURTLES_ TERRAPENE_CAROLINA_CAROLINA_COMPARISONS_OF_SURVIVAL_AND_ OVERWINTERING_ECOLOGY

Farnsworth SD, Seigel RA (2013) Responses, movements, and survival of relocated box turtles during construction of the intercounty connector highway in Maryland. Transp Res Rec 2362:1-8. doi:10.3141/2362-01

Fijan N, Matasin Z, Petrinec Z et al (1991) Isolation of an iridovirus-like agent from the green frog (Rana esculenta L.). Vet Arch Zagreb 61:151-158

Forzán M, Wood J (2013) Low detection of ranavirus DNA in wild postmetamorphic green frogs, Rana (Lithobates) clamitans, despite previous or concurrent tadpole mortality. J Wildl Dis 49:879-886

Fox SF, Greer AL, Tores-Cervantes R et al (2006) First case of ranavirus-associated morbidity and mortality in natural populations of the South American frog, Atelognathus patagonicus. Dis Aquat Organ 72:87-92

Francis-Floyd R (1992) Comparative hematology for largemouth bass (Micropterus salmoides) and black crappie (Pomoxis nigromaculatus) from Lake Weir, Lake Holy, and Newman's Lake. Final report. Florida Freshwater Game and Fish Commission, Tallahassee

Gahl MK, Calhoun AJK (2010) The role of multiple stressors in ranavirus-caused amphibian mortalities in Acadia National Park wetlands. Can J Zool 88:108-118

Galli L, Pereira A, Márquez A et al (2006) Ranavirus detection by PCR in cultured tadpoles (Rana catesbeiana Shaw, 1802) from South America. Aquaculture 257:78-82

Geng Y, Wang KY, Zhou ZY et al (2011) First report of a ranavirus associated with morbidity and mortality in farmed Chinese giant salamanders. J Comp Pathol 145:95-112

George, MR, John KR, Mansoor MM, Saravanakumar R, Sundar P, Pradeep V (2014) Isolation and characterization of a ranavirus from koi, Cyprinus carpio L., experiencing mass mortalities in India. J Fish Dis. doi:10.1111/jfd.12246

Glenney JW, Julian JT, Quartz WM (2010) Preliminary amphibian health survey in the Delaware Water Gap National Recreation Area. J Aquat Anim Health 22:102-114

Gobbo F, Cappellozza E, Pastore MR et al (2010) Susceptibility of black bullhead Ameiurus melas to a panel of ranavirus isolates. Dis Aquat Organ 90:167-174

Goldberg TL (2002) Largemouth bass virus: an emerging problem for warmwater fisheries? In: Philipp DP, Ridgway MS (eds) Black bass: ecology, conservation and management. American Fisheries Society Symposium, Bethesda

Goodman RM, Miller DL, Ararso YT (2013) Prevalence of ranavirus in Virginia turtles as detected by tail-clip sampling versus oral-cloacal swabbing. Northeast Nat 20:325-332

Granoff A, Came PE, Rafferty KA (1965) The isolation and properties of viruses from Rana pipiens: their possible relationship to the renal adenocarcinoma of the leopard frog. Ann N Y Acad Sci 126:237-255

Grant EC, Inendino KR, Love WJ et al (2005) Effects of practices related to catch-and-release angling on mortality and viral transmission in juvenile largemouth bass infected with largemouth bass virus. J Aquat Anim Health 17:315-322

Gray MJ, Miller DL, Schmuster AC et al (2007) Frog virus 3 prevalence in tadpole populations at cattle-access and non-access wetlands in Tennessee, USA. Dis Aquat Organ 77:97-103

Gray MJ, Miller DL, Hoverman JT (2009a) Ecology and pathology of amphibian ranaviruses. Dis Aquat Organ 87:243-266

Gray MJ, Miller DL, Hoverman JT (2009b) First report of ranavirus infecting lungless salamanders. Herpetol Rev 40:316-319

Gray MJ, Brunner JL, Earl JE, Ariel E (2015) Design and analysis of ranavirus studies: surveillance and assessing risk. In: Gray MJ, Chinchar VG (eds) Ranaviruses: lethal pathogens of ectothermic vertebrates. Springer, New York 
Green DE, Converse KA (2005) Diseases of frogs and toads. In: Majumadar SK, Huffman JE, Brenner FJ et al (eds) Wildlife diseases: landscape epidemiology, spatial distribution and utilization of remote sensing techniques. The Pennsylvania Academy of Science, Easton, pp 89-117

Green DE, Converse KA, Schrader AK (2002) Epizootiology of sixty-four amphibian morbidity and mortality events in the USA, 1996-2001. Ann N Y Acad Sci 969:323-339

Greer AL, Berrill M, Wilson PJ (2005) Five amphibian mortality events associated with ranavirus infection in south central Ontario, Canada. Dis Aquat Organ 67:9-14

Greer AL, Brunner JL, Collins JP (2009) Spatial and temporal patterns of Ambystoma tigrinum virus (ATV) prevalence in tiger salamanders Ambystoma tigrinum nebulosum. Dis Aquat Organ 85:1-6

Grizzle JM, Brunner CJ (2003) Review of largemouth bass virus. Fisheries 28:10-14

Grizzle JM, Altinok I, Fraser WA et al (2002) First isolation of largemouth bass virus. Dis Aquat Organ 50:233-235

Groocock GH, Grimmett SG, Getchell RG et al (2008) A survey to determine the presence and distribution of largemouth bass virus in wild freshwater bass in New York State. J Aquat Anim Health 20:158-164

Haislip NA, Gray MJ, Hoverman JT et al (2011) Development and disease: how susceptibility to an emerging pathogen changes through anuran development. PLoS One 6:e22307

Hamed MK, Gray MJ, Miller DL (2013) First report of ranavirus in plethodontidae salamanders from the Mount Rogers National Recreation Area, Virginia, USA. Herpetol Rev 44:455-457

Hanson LA, Petrie-Hansons L, Meals KO et al (2001) Persistence of large-mouth bass virus infection in a northern Mississippi reservoir after a die-off. J Aquat Anim Health 13:27-34

Harp EM, Petranka JW (2006) Ranavirus in wood frogs (Rana sylvatica): potential sources of transmission within and between ponds. J Wildl Dis 42:307-318

Heard MJ, Smith KF, Ripp KJ et al (2013) The threat of disease increases as species move towards extinction. Conserv Biol 24:1378-1388

Hedrick RP, McDowell TS (1995) Properties of iridoviruses from ornamental fish. Vet Res 26:423-427

Heldstab A, Bestetti G (1982) Spontaneous viral hepatitis in a spur-tailed Mediterranean land tortoise. J Zoo Anim Med 13:113-120

Holopainen R, Ohlemeyer S, Schuetze H et al (2009) Ranavirus phylogeny and differentiation based on major capsid protein, DNA polymerase and neurofilament triplet H1-like protein genes. Dis Aquat Organ 85:81-91

Homan RN, Bartling JR, Stenger RJ et al (2013) Detection of ranavirus in Ohio, USA. Herpetol Rev 44:615-618

Hoverman JT, Gray MJ, Miller DL (2010) Anuran susceptibility to ranaviruses: role of species identity, exposure route and a novel virus isolate. Dis Aquat Organ 98:97-107

Hoverman JT, Gray MJ, Haislip NA et al (2011) Phylogeny, life history, and ecology contribute to differences in amphibian susceptibility to ranaviruses. Ecohealth 8:301-319

Hoverman JT, Gray MJ, Haislip NA et al (2012a) Widespread occurrence of ranavirus in pond breeding amphibian populations. Ecohealth 9:36-48

Hoverman JT, Mihaljevic JR, Richgels LD et al (2012b) Widespread co-occurrence of virulent pathogens within California amphibian communities. Ecohealth 9:288-292

Huang Y, Huang X, Liu H et al (2009) Complete sequence determination of a novel reptile iridovirus isolated from soft-shelled turtle and evolutionary analysis of Iridoviridae. BMC Genomics $10: 224$

Huang SM, Tu C, Tseng CH et al (2011) Genetic analysis of fish iridoviruses isolated in Taiwan during 2001-2009. Arch Virol 156:1505-1515

Hyatt AD, Gould AR, Zupanovic Z et al (2000) Comparative studies of piscine and amphibian iridoviruses. Arch Virol 145:301-331

Hyatt AD, Williamson M, Coupar BEH et al (2002) First identification of a ranavirus from green pythons (Chondropython viridis). J Wildl Dis 38:239-252 
Iwanowicz L, Densmore C, Hahn C et al (2013) Identification of largemouth bass virus in the introduced Northern snakehead inhabiting the Chesapeake Bay Watershed. J Aquat Anim Health 25:191-196

Jancovich JK, Davidson EW, Morado JF et al (1997) Isolation of a lethal virus from the endangered tiger salamander Ambystoma tigrinum stebbinsi. Dis Aquat Organ 31:161-167

Jancovich JK, Davidson EW, Seiler A et al (2001) Transmission of the Ambystoma tigrinum virus to alternative hosts. Dis Aquat Organ 46:159-163

Jancovich JK, Davidson EW, Parameswaran N et al (2005) Evidence for emergence of an amphibian iridoviral disease because of human-enhanced spread. Mol Ecol 14:213-224

Jancovich JK, Bremont M, Touchman JW et al (2010) Evidence for multiple recent host species shifts among the ranaviruses (family Iridoviridae). J Virol 84:2636-2647

Jancovich JK, Steckler N, Waltzek TB (2015) Ranavirus taxonomy and phylogeny. In: Gray MJ, Chinchar VG (eds) Ranaviruses: lethal pathogens of ectothermic vertebrates. Springer, New York

Johnson AJ (2006) Iridovirus infections of captive and free-ranging chelonians in the United States. Ph.D. Thesis, Veterinary Medicine. University of Florida, Gainesville, p 149

Johnson AJ, Pessier AP, Jacobson ER (2007) Experimental transmission and induction of ranaviral disease in western ornate box turtles (Terrapene ornata ornata) and red-eared sliders (Trachemys scripta elegans). Vet Pathol 44:285-297

Johnson AJ, Pessier AP, Wellehan JFX et al (2008) Ranavirus infection of free-ranging and captive box turtles and tortoises in the United States. J Wildl Dis 44:851-863

Johnson AJ, Wendland L, Norton TM et al (2010) Development and use of an indirect enzymelinked immunosorbent assay for detection of iridovirus exposure in gopher tortoises (Gopherus polyphemus) and eastern box turtles (Terrapene carolina carolina). Vet Microbiol 142:160-167

Juhász T, Woynarovichne LM, Csaba G et al (2013) Isolation of ranavirus causing mass mortality in brown bullheads (Ameiurus nebulosus) in Hungary. Magyar Allatorvosok Lapja $135: 763-768$

Kanchanakhan S (1998) An ulcerative disease of the cultured tiger frog, Rana tigrina, in Thailand: virological examination. AAHRI Newsl 7:1-2

Kik M, Martel A, Spitzen-van der Sluijs A et al (2011) Ranavirus associated mass mortality in wild amphibians in the Netherlands, 2010: a first report. Vet J 190:284-286

Kik M, Stege M, Boonyarittichaikij R et al (2012) Concurrent ranavirus and Batrachochytrium dendrobatidis infection in captive frogs (Phyllobates and Dendrobates species), the Netherlands, 2012: a first report. Vet J 194:247-249

Kimble SJ, Karna AK, Johnson AJ et al (2014) Mosquitoes as a potential vector of ranavirus transmission in terrestrial turtles. EcoHealth. doi:10.1007/s10393-014-0974-3

Kolby JE, Smith KM, Berger L et al (2014) First evidence of amphibian chytrid fungus (Batrachochytrium dendrobatidis) and ranavirus in Hong Kong amphibian trade. PLoS One 9:e90750

Landsberg JH, Kiryu Y, Tabuchi M et al (2013) Co-infection by alveolate parasites and frog virus 3-like ranavirus during and amphibian larval mortality event in Florida, USA. Dis Aquat Organ 105:89-99

Langdon, JS (1989) Experimental transmission and pathogenicity of epizootic hematopoietic necrosis virus (ehnv) in redfin perch, perca-fluviatilis 1 and 11 other teleosts. Journal of Fish Diseases, 12, 295-310

Langdon JS, Humphrey JD (1987) Epizootic haematopoietic necrosis a new viral disease in redfin perch Perca fluviatilis L. in Australia. J Fish Dis 10:289-298

Langdon JS, Humphrey JD, Copland J et al (1986a) The disease status of Australian salmonids: viruses and viral diseases. J Fish Dis 9:129-135

Langdon JS, Humphrey JD, Williams LM et al (1986b) First virus isolation from Australian fish: an iridovirus-like pathogen from redfin perch, Perca fluviatilis L. J Fish Dis 9:263-268

Langdon JS, Humphrey JD, Williams LM (1988) Outbreaks of an EHNV-like iridovirus in cultured rainbow trout, Salmo gairdneri Richardson, in Australia. J Fish Dis 11:93-96 
Lei X-Y, Ou T, Zhu R-L et al (2012) Sequencing and analysis of the complete genome of Rana grylio virus (RGV). Arch Virol 157:1559-1564

Leimbach S, Schütze H, Bergmann SM (2014) Susceptibility of European sheatfish Silurus glanis to a panel of ranaviruses. J Appl Ichthyol 30:93-101

Ma J, Zeng L, Zhou Y et al (2014) Ultrastructural morphogenesis of an amphibian iridovirus isolated from Chinese giant salamander (Andrias davidianus). J Comp Pathol 150:325-331

Majji S, LaPatra S, Long SM et al (2006) Rana catesbeiana virus Z (RCV-Z): a novel pathogenic ranavirus. Dis Aquat Organ 73:1-11

Mao J, Hedrick RP, Chinchar VG (1997) Molecular characterization, sequence analysis, and taxonomic position of newly isolated fish iridoviruses. Virology 229:212-220

Mao JD, Green E, Fellers G et al (1999a) Molecular characterization of iridoviruses isolated from sympatric amphibians and fish. Virus Res 63:45-52

Mao JH, Wang J, Chinchar GD et al (1999b) Molecular characterization of a ranavirus isolated from largemouth bass Micropterus salmoides. Dis Aquat Organ 37:107-114

Marschang RE, Becher P, Posthaus H et al (1999) Isolation and characterization of an iridovirus from Hermann's tortoises (Testudo hermanni). Arch Virol 144:1909-1922

Marschang RE, Braun S, Becher P (2005) Isolation of a ranavirus from a gecko (Uroplatus fimbriatus). J Zoo Wildl Med 36:295-300

Marschang RE, Stöhr AC, Blahak S et al (2013) Ranaviruses in snakes, lizards, and chelonians. In: Proceedings of second international symposium on ranaviruses, Knoxville, 27-29 July

Marsh IB, Whittington RJ, O'Rourke B et al (2002) Rapid differentiation of Australian, European and American ranaviruses based on variation in major capsid protein gene sequence. Mol Cell Probes 16:137-151

Martel A, Fard MS, van Rooij P et al (2012) Road-killed common toads (Bufo bufo) in Flanders (Belgium) reveal low prevalence of ranavirus and Batrachochytrium dendrobatidis. J Wildl Dis 48:835-839

Mavian C, Lopez-Bueno A, Balseiro A et al (2012) The genome sequence of the emerging common midwife toad virus identifies an evolutionary intermediate within ranaviruses. J Virol $86: 3617-3625$

Mazzoni R, José de Mesquita A, Fleury LFF et al (2009) Mass mortality associated with frog virus 3-like ranavirus infection in farmed tadpoles, Rana catesbeiana, from Brazil. Dis Aquat Organ 86:181-191

Miller DL, Rajeev S, Gray MJ et al (2007) Frog virus 3 infection, cultured American bullfrogs. Emerg Infect Dis 13:342-343

Miller DL, Rajeev S, Brookins M et al (2008) Concurrent infection with Ranavirus, Batrachochytrium dendrobatidis, and Aeromonas in a captive amphibian colony. J Zoo Wildl Med 39:445-449

Miller DL, Gray MJ, Rajeev S et al (2009) Pathological findings in larval and juvenile anurans inhabiting farm ponds in Tennessee, USA. J Wildl Dis 45:314-324

Miller D, Gray M, Storfer A (2011) Ecopathology of ranaviruses infecting amphibians. Viruses 3:2351-2373

Miller DL, Pessier AP, Hick P, Whittington RJ (2015) Comparative pathology of ranaviruses and diagnostic techniques. In: Gray MJ, Chinchar VG (eds) Ranaviruses: lethal pathogens of ectothermic vertebrates. Springer, New York

Monson-Collar K, Hazard L, Dolcemascolo P (2013) A Ranavirus-related mortality recent and the first report of Ranavirus in New Jersey. Herpetol Rev 44:263-265

Moody NJG, Owens L (1994) Experimental demonstration of pathogenicity of a frog virus, Bohle iridovirus, for fish species, barramundi Lates calcifer. Dis Aquat Organ 18:95-102

Müller M, Zangger N, Denzler T (1988) Iridovirus-epidemie bei der griechischen landschildkröte (Testudo hermanni hermanni). Verhandl Ber 30. Int Symp Erkr Zoo- und Wildtiere, Sofia, pp 271-274

Murali S, Wu MF, Guo IC et al (2002) Molecular characterization and pathogenicity of a grouper iridovirus (GIV) isolated from yellow grouper, Epinephelus awoara (Temminck \& Schlegel). J Fish Dis 25:91-100 
Neal JW, Eggleton MA, Goodwin AE (2009) The effects of largemouth bass virus on a quality largemouth bass population in Arkansas. J Wildl Dis 45:766-771

O'Bryan CJ, Gray MJ, Brooks CS (2012) Further presence of ranavirus infection in amphibian populations of Tennessee, USA. Herpetol Rev 43:293-295

OIE (2008) Aquatic animal health code. Section 2.4 diseases of amphibians. http://www.oie.int/ international-standard-setting/aquatic-code/. Accessed 20 March 2014

Paetow LJ, Pauli BD, McLaughlin JD et al (2011) First detection of ranavirus in Lithobates pipiens in Quebec. Herpetol Rev 42:211-214

Pasmans F, Blahak S, Martel A et al (2008) Ranavirus-associated mass mortality in imported red tailed knobby newts (Tylototriton kweichowensis): a case report. Vet J 175:257-259

Pearman PB, Garner TWJ (2005) Susceptibility of Italian agile frog populations to an emerging strain of Ranavirus parallels population genetic diversity. Ecol Lett 8:401-408

Pearman PB, Garner TWJ, Straub M et al (2004) Response of the Italian agile frog (Rana latastei) to a Ranavirus, frog virus 3: a model for viral emergence in naïve populations. J Wildl Dis 40:660-669

Petranka JW, Murray SM, Kennedy CA (2003) Response of amphibians to restoration of a southern Appalachian wetland: perturbations confounded post-restoration assessment. Wetlands 23:278-290

Picco AM, Collins JP (2008) Amphibian commerce as a likely source of pathogen pollution. Conserv Biol 22:1582-1589

Picco AM, Brunner JL, Collins JP (2007) Susceptibility of the endangered California tiger salamander, Ambystoma californiense, to Ranavirus infection. J Wildl Dis 43:286-290

Picco AM, Karam AP, Collins JP (2010) Pathogen host switching in commercial trade with management recommendations. Ecohealth 7:252-256

Plumb JA, Hanson LA (2011) Health maintenance and principal microbial diseases of cultured fishes. Wiley, Hoboken

Plumb JA, Zilberg D (1999a) Survival of largemouth bass iridovirus in frozen fish. J Aquat Anim Health 11:94-96

Plumb JA, Zilberg D (1999b) The lethal dose of largemouth bass virus in juvenile largemouth bass and the comparative susceptibility of striped bass. J Aquat Anim Health 11:246-252

Plumb JA, Grizzle JM, Young HE et al (1996) An iridovirus isolated from wild largemouth bass. J Aquat Anim Health 8:265-270

Plumb JA, Noyes AD, Graziono S et al (1999) Isolation and identification of viruses from adult largemouth bass during a 1997-1998 survey in the southeastern United States. J Aquat Anim Health 11:391-399

Pozet F, Morand M, Moussa A et al (1992) Isolation and preliminary characterization of a pathogenic icosahedral deoxyribovirus from the catfish Ictalurus melas. Dis Aquat Organ $14: 35-42$

Prasankok P, Chutmongkonkul M, Kanchankhan S (2005) Characterization of iridovirus isolated from diseased marbled sleepy goby, Oxyeleotris marmoratus. In: Walker PJ, Lester RG, Bondad-Reantaso M (eds) Diseases in Asian Aquaculture V. Asian Fisheries Society, Manila

Price, SJ, Garner TWJ, Nichols RA, et al. (2014) Collapse of amphibian communities due to an introduced Ranavirus. Curr Biol 24:2586-2591. http://www.cell.com/current-biology/pdfExtended/S0960-9822(14)01149-X

Qin QW, Chang SF, Ngoh-lim GH et al (2003) Characterization of a novel ranavirus isolated from grouper Epinephelus tauvina. Dis Aquat Organ 53:1-9

Richter SC, Drayer AN, Strong JR et al (2013) High prevalence of ranavirus infection in permanent constructed wetlands in eastern Kentucky, USA. Herpetol Rev 44:464-466

Ridenhour BJ, Storfer AT (2008) Geographically variable selection in Ambystoma tigrinum virus (Iridoviridae) throughout the western USA. J Evol Biol 21:1151-1159

Rothermel BR, Travis ER, Miller DL et al (2013) High occupancy of stream salamanders despite high Ranavirus prevalence in a southern Appalachians watershed. Ecoheath 10:184-189

Ruder MG, Allison AB, Miller DL et al (2010) Pathology in practice. J Am Vet Med Assoc 237:783-785 
Russell DM, Goldberg CS, Sprague L et al (2011) Ranavirus outbreaks in amphibian populations of northern Idaho. Herpetol Rev 42:223-225

Schloegel LM, Picco AM, Kilpatrick AM et al (2009) Magnitude of the US trade in amphibians and presence of Batrachochytrium dendrobatidis and ranavirus infection in imported North American bullfrogs (Rana catesbeiana). Biol Conserv 142:1420-1426

Schloegel LM, Daszak P, Cunningham AA et al (2010) Two amphibian diseases, chytridiomycosis and ranaviral disease, are now globally notifiable to the World Health Organization for Animal Health (OIE): an assessment. Dis Aquat Organ 92:101-108

Schock DM, Bollinger TK, Chinchar VG et al (2008) Experimental evidence that amphibian ranaviruses are multi-host pathogens. Copeia 1:133-143

Schock DM, Ruthig GR, Collins JP et al (2010) Amphibian chytrid fungus and ranaviruses in the Northwest Territories, Canada. Dis Aquat Organ 92:231-240

Schramm HL Jr, Davis JG (2006) Survival of largemouth bass from populations infected with largemouth bass virus and subjected to simulated tournament conditions. N Am J Fish Manag 26:826-832

Sharifian-Fard M, Pasmans F, Adriaensen C et al (2011) Ranaviruses in invasive bullfrogs, Belgium. Emerg Infect Dis 17:2371-2372

Shaver K (2012) In Md., fear for the turtles. http://www.washingtonpost.com/local/commuting/2012/02/01/gIQA5O0Z9Q_story.html. Accessed 31 July 2014

Sim RR, Wack AN, Allender AC, Murphy KJ, Bronson E (2012) Management of a concurrent ranavirus and herpesvirus epizootic event incaptive eastern box turtles (Terrapene carolina carolina). Proceedings Association of Reptilian and Amphibian Veterinarians

Southard GM, Fries LT, Terre DR (2009) Largemouth bass virus in Texas: distribution and management issues. J Aquat Anim Health 21:36-42

Souza MJ, Gray MJ, Colclough P et al (2012) Prevalence of infection by Batrachochytrium dendrobatidis and Ranavirus in eastern Hellbenders (Cryptobranchus alleganeiensis alleganeiensis). J Wildl Dis 48:560-566

Speare R, Smith JR (1992) An iridovirus-like agent isolated from the ornate burrowing frog, Limnodynastes in northern Australia. Dis Aquat Organ 14:51-57

Speare R, Freeland WJ, Bolton SJ (1991) A possible iridovirus in erythrocytes of Bufo marinus in Costa Rica. J Wildl Dis 27:457-462

St Amour V, Wong WM, Garner TWJ et al (2008) Anthropogenic influence on prevalence of 2 amphibian pathogens. Emerg Infect Dis 12:1175-1176

Stark T, Laurijssens C, Weterings M et al (2014) Death in the clouds: Ranavirus associated mortality in an assemblage of cloud forest amphibians in Nicaragua. Acta Herpetol 9:125-127

Stöhr AC, Hoffmann A, Papp T et al (2013a) Long-term study of an infection with ranaviruses in a group of edible frogs (Pelophylax kl. esculentus) and partial characterization of two viruses based on four genomic regions. Vet J 197:238-244

Stöhr AC, Blahak S, Heckers KO et al (2013b) Ranavirus infections associated with skin lesions in lizards. Vet Res 44:84

Stöhr AC, Fleck J, Mutchmann F et al (2013c) Ranavirus infection in a group of wild caught Lake Urmia newts Neurergus crocatus importuned from Iraq to Germany. Dis Aquat Organ 103:185-189

Stöhr AC, Heckers KO, Ball L et al (2013d) Coinfection with multiple viruses in European pond turtles (Emys orbicularis). In: Proceedings of Association of Reptilian and Amphibian Veterinarians, Indianapolis

Stöhr AC, López-Bueno A, Blahak S, Caeiro MF, Rosa GM, et al. (2015) Phylogeny and Differentiation of Reptilian and Amphibian Ranaviruses Detected in Europe. PLoS ONE 10(2): e0118633. doi:10.1371/journal.pone.0118633

Storfer A, Alfaro ME, Ridenhour BJ et al (2007) Phylogenetic concordance analysis shows an emerging pathogen is novel and endemic. Ecol Lett 10:1075-1083

Tapiovaara H, Olesen NJ, Linden J et al (1998) Isolation of an iridovirus from pike-perch Stizostedion lucioperca. Dis Aquat Organ 32:185-193 
Teacher AGF, Cunningham AA, Garner TWJ (2010) Assessing the long-term impacts of Ranavirus infection on wild common frog populations. Anim Conserv 13:514-522

Todd-Thompson M (2010) Seasonality, variation in species prevalence and localized disease for ranavirus in Cades Cove (Great Smoky Mountains National Park) amphibians. M.Sc. Thesis, University of Tennessee, Knoxville

Torrence SM, Green DE, Benson CJ et al (2010) A new ranavirus isolated from Pseudacris clarkii tadpoles in Playa wetlands in the southern High Plains, Texas. J Aqaut Anim Health 22:65-72

Une Y, Nakajinma K, Taharaguchi S et al (2009a) Ranavirus infection outbreak in the salamander (Hynobius nebulosus) in Japan. J Comp Pathol 141:310

Une Y, Sakuma A, Matsueda H et al (2009b) Ranavirus outbreak in North American bullfrogs (Rana catesbeiana), Japan. Emerg Infect Dis 15:1146-1147

USFWS (2011) National wild fish health survey database. USFWS, Washington, DC. www.fws. gov/wildfishsurvey/database/nwfhs. Accessed 20 May 2014

USGS 2005. USGS National Wildlife Health Center Quarterly Wildlife Mortality ReportApril 2005 to June 2005. http://www.nwhc.usgs.gov/publications/quarterly_reports/2005_qtr_2.jsp

USGS 2008. USGS National Wildlife Health Center Quarterly Wildlife Mortality ReportOctober 2008 to December 2008 http://www.nwhc.usgs.gov/publications/quarterly_reports/2008_qtr_4.jsp

Uyehara IK, Gamble T, Cotner S (2010) The presence of Ranavirus in anuran populations at Itasca State Park, Minnesota, USA. Herpetol Rev 41:177-179

Waltzek TB, Miller DL, Gray MJ et al (2014) New disease records for hatchery-reared sturgeon: expansion of host range of frog virus 3 into pallid sturgeon, Scaphirhynchus albus. Dis Aquat Organ 111(3):219-227

Weir RP, Moody NJG, Hyatt AD (2012) Isolation and characterization of a novel Bohle-like virus from two frog species in the Darwin rural area, Australia. Dis Aquat Organ 99:169-177

Weng SP, He JG, Wang XH et al (2002) Outbreaks of an iridovirus disease in cultured tiger frog, Rana tigrina rugulosa, in southern China. J Fish Dis 25:423-427

Westhouse RA, Jacobson ER, Harris RK et al (1996) Respiratory and pharyngo-esophageal iridovirus infection in a gopher tortoise (Gopherus polyphemus). J Wildl Dis 32:682-686

Whitfield SM, Geerdes E, Chacon I et al (2013) Infection and co-infection by the amphibian chytrid fungus and ranavirus in wild Costa Rican frogs. Dis Aquat Organ 104:173-178

Whittington RJ, Reddacliff GL (1995) Influence of environmental temperature on experimental infection of redfin perch (Perca fluviatilis) and rainbow trout (Oncorhynchus mykiss) with epizootic haematopoietic necrosis virus, an Australian iridovirus. Aust Vet J 72:421-424

Whittington RJ, Philbey A, Reddacliff GL et al (1994) Epidemiology of epizootic haematopoietic necrosis virus (EHNV) infection in farmed rainbow trout, Oncorhynchus mykiss (Walbaum): findings based on virus isolation, antigen capture ELISA and serology. J Fish Dis 17:205-218

Whittington RJ, Kearns C, Hyatt AD et al (1996) Spread of epizootic haematopoietic necrosis virus (EHNV) in redfin perch (Perca fluviatilis) in southern Australia. Aust Vet J 73:112-114

Whittington RJ, Reddacliff LA, Marsh I et al (1999) Further observations on the epidemiology and spread of epizootic haematopoietic necrosis virus (EHNV) in farmed rainbow trout Oncorhynchus mykiss in southeastern Australia and a recommended sampling strategy for surveillance. Dis Aquat Organ 35:125-130

Whittington RJ, Becker JA, Dennis MM (2010) Iridovirus infections in finfish-critical review with emphasis on ranaviruses. J Fish Dis 33:95-122

Wolf K, Bullock GL, Dunbar CE et al (1969) Tadpole edema virus: a viscerotropic pathogen for anuran amphibians. J Infect Dis 118:253-262

Woodland JE, Brunner CJ, Noyes AD et al (2002a) Experimental oral transmission of largemouth bass virus. J Fish Dis 25:669-672

Woodland JE, Noyes AD, Grizzle JM (2002b) A survey to detect largemouth bass virus among fish from hatcheries in the southeastern USA. Trans Am Fish Soc 131:308-311

Xu K, Zhu D, Wei Y et al (2010) Broad distribution of ranavirus in free-ranging Rana dybowskii, in Heilongjiang, China. Ecohealth 7:18-23 
Zhang Q, Li Z, Jiang Y et al (1996) Preliminary studies on virus isolation and cell infection from diseased frog Rana grylio. Acta Hydrobiol Sin 4:390-392

Zhang QY, Xiao F, Li ZQ et al (2001) Characterization of an iridovirus from the cultured pig frog, Rana grylio, with lethal syndrome. Dis Aquat Organ 48:27-36

Zhou ZY, Geng Y, Liu XX et al (2013) Characterization of a ranavirus isolated from the Chinese giant salamander (Andrias davidianus, Blanchard, 1871) in China. Aquaculture 384387:66-73

Zilberg D, Grizzle JM, Plumb JA (2000) Preliminary description of lesions in juvenile largemouth bass injected with largemouth bass virus. Dis Aquat Organ 39:143-146

Zupanovic Z, Lopez G, Hyatt AD et al (1998a) Giant toads, Bufo marinus, in Australia and Venezuela have antibodies against ranaviruses. Dis Aquat Organ 32:1-8

Zupanovic Z, Musso C, Lopez G et al (1998b) Isolation and characterization of iridoviruses from the giant toad Bufo marinus in Venezuela. Dis Aquat Organ 33:1-9 


\title{
Ranavirus Taxonomy and Phylogeny
}

\author{
James K. Jancovich, Natalie K. Steckler, and Thomas B. Waltzek
}

\section{Introduction}

Nucleocytoplasmic Large DNA Viruses (NCLDV) are a monophyletic cluster of viruses that infect eukaryotes, ranging from single-celled organisms to humans, worldwide. The NCLDV group encompasses six virus families: Poxviridae, Asfarviridae, Iridoviridae, Ascoviridae, Mimiviridae, and Phycodnaviridae (Yutin and Koonin 2012; Yutin et al. 2009; Fig. 1). In addition, Marseillevirus isolates can be classified as members of the NCLDV, and there may be more viral isolates and families that will join the NCLDV cluster as our understanding of this important and complex group of dsDNA viruses expands. Recently, a proposal has been made to the International Committee on Taxonomy of Viruses (ICTV), the organization that oversees viral taxonomy, to classify NCLDV into a new order, designated Megavirales (Colson et al. 2012, 2013). Classification of NCLDV into a defined hierarchy will provide needed taxonomic structure for large dsDNA viruses. While this proposed taxonomic change will most likely be accepted in the near future, until then, our discussion will refer to this group as the NCLDV cluster of viruses.

Members within the NCLDV group have some of the largest known viral genomes. For example, members of the family Mimiviridae have genomes that are $\sim 1.2$ million base pairs (bp) in size and encode more than 1,000 viral genes

\footnotetext{
J.K. Jancovich $(\bowtie)$

Department of Biological Sciences, California State University, 333 S. Twin Oaks Valley Rd, San Marcos, CA 92096, USA

e-mail: jjancovich@csusm.edu

N.K. Steckler • T.B. Waltzek

Department of Infectious Diseases and Pathology, College of Veterinary Medicine,

University of Florida, Gainesville, FL 32611, USA
} 
Fig. 1 Phylogenetic representation of the NCLDV group members. The graphical representation tree was developed from a phylogeny based on 263 amino acids from a conserved region of the DNA polymerase $\mathrm{B}$ gene originally published by Yutin et al. (2009). Tree is not to scale

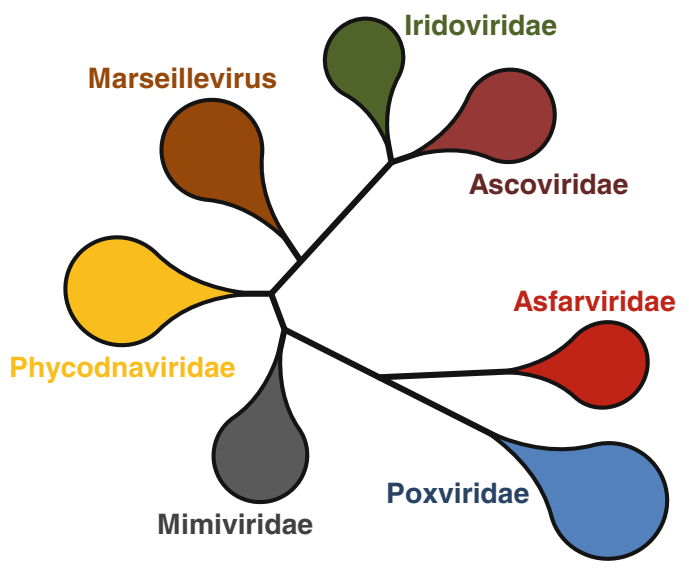

(Raoult et al. 2004). They replicate within the cytoplasm of infected cells, although some members (e.g., family Iridoviridae) also include a nuclear stage during their replication cycle. As a result, NCLDV members encode many of the genes necessary for replication within the cytoplasm but still rely completely on the host translational machinery. Comparative analysis of NCLDV genomes reveals a core set of 50 viral genes that are conserved among the NCLDV (Yutin and Koonin 2012), supporting the hypothesis that this cluster of viruses originated from a common ancestor. Although the best-characterized family within the NCLDV is the Poxviridae, which includes a major human pathogen (smallpox virus), our understanding of the molecular biology, ecology, and infection dynamics of other families within the NCLDV, particularly members of the family Iridoviridae, has increased significantly in recent decades.

The family Iridoviridae is composed of five genera: the Iridovirus and Chloriridovirus genera whose members infect invertebrate hosts and the Megalocytivirus, Lymphocystivirus, and Ranavirus genera that infect cold-blooded vertebrates (Jancovich et al. 2012). Iridoviruses have linear dsDNA genomes that are circularly permutated and terminally redundant (Goorha and Murti 1982). Genome size is highly variable within the family and ranges from 140 to $303 \mathrm{kbp}$. However, because genomes are terminally redundant, unit-length genome sizes (i.e., the sum of the size of only the unique genes) are smaller and range from 105 to $212 \mathrm{kbp}$ (Jancovich et al. 2012). Viruses within the family Iridoviridae share 26 core genes (Eaton et al. 2007). This cluster of core genes includes viral structural proteins as well as proteins involved in the regulation of gene expression, virus replication, and virulence (Jancovich et al. 2015; Grayfer et al. 2015). Sequence analysis of the 26 core genes has been used to generate high-resolution phylogenies (Fig. 2) for members of the family Iridoviridae as well as members of the genus Ranavirus (Jancovich et al. 2012). 


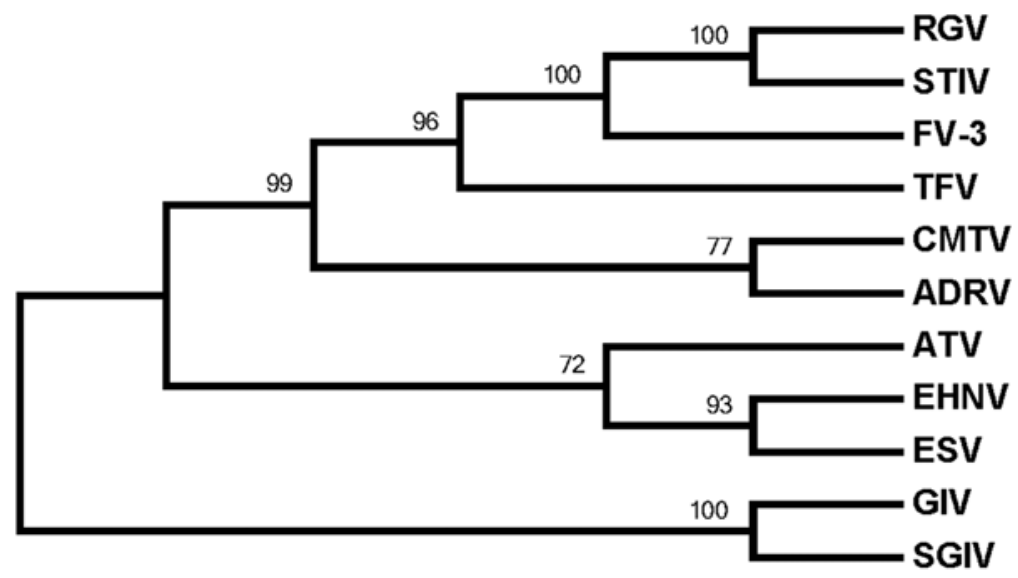

Fig. 2 Cladogram depicting the evolutionary relationships among the 11 fully sequenced ranaviruses, based on aligned deduced amino acid (AA) sequences of the concatenated 26 conserved iridovirus genes as defined by Eaton et al. (2007). The dataset contained 13,287 aligned AA positions. Maximum likelihood analysis was conducted in MEGA6 (Tamura et al. 2013). Numbers above each node represent the bootstrap values (1,000 replicates). See Table 1 for taxa abbreviations

\section{Ranavirus Taxonomy}

Members of the genus Ranavirus are a promiscuous group of viruses capable of infecting a wide variety of cold-blooded vertebrate hosts including fish, amphibians, and reptiles (Marschang 2011; Miller et al. 2011; Whittington et al. 2010). In addition, it has been hypothesized that ranaviruses have recently in their evolutionary history jumped from fish to amphibians and reptiles (Jancovich et al. 2010; Mavian et al. 2012a). This wide host range has been the focus of much ranavirus research, as investigators seek to understand how ranaviruses are able to infect such a wide variety of hosts (Brenes et al. 2014), when in evolutionary history did jumps from fish to other cold-blooded vertebrates occur (Chen et al. 2013; Jancovich et al. 2010; Mavian et al. 2012a), and what genetic elements contribute to ranavirus host range and pathogenesis (Jancovich et al. 2015).

There are currently six species recognized by the ICTV within the genus Ranavirus (Jancovich et al. 2012). These species include Frog virus 3 (FV3), the type species of the genus, and the best-characterized member of the family Iridoviridae; Ambystoma tigrinum virus (ATV); Bohle iridovirus (BIV); Epizootic hematopoietic necrosis virus (EHNV); European catfish virus (ECV); and SanteeCooper ranavirus (SCRV; Jancovich et al. 2012). Moreover, there are other genetically distant ranaviruses that have not yet been recognized as species by the ICTV Iridoviridae Study Group. These include Singapore grouper iridovirus (SGIV; Song et al. 2004), grouper iridovirus (GIV), Rana esculenta virus (REV; Holopainen et al. 2009), common midwife toad virus (CMTV; Mavian et al. 2012a), Andrias davidianus ranavirus (ADRV; also known as Chinese giant salamander iridovirus; 
Chen et al. 2013), cod iridovirus (CoIV; Ariel et al. 2010), short-finned eel ranavirus (SERV; Holopainen et al. 2009), pike-perch iridovirus (PPIV; Holopainen et al. 2009), and Ranavirus maxima (Rmax; Ariel et al. 2010). Multiple criteria are used to delineate members within the genus Ranavirus including restriction endonuclease fragment length polymorphism (RFLP) profiles of genomic DNA, virus protein profiles, DNA sequence analysis, and host specificity (Jancovich et al. 2012). In addition to these criteria, dot plot analysis using complete genomic sequence information as well as phylogenetic analysis of individual and concatenated gene sequences have provided insight into the taxonomy of the ranaviruses (Eaton et al. 2007; Jancovich et al. 2010; Mavian et al. 2012a; Tan et al. 2004; Wang et al. 2014). Dot plot analyses offer a general overview of ranavirus genomic organization and a visual way to identify insertions, deletions, and inversions within viral genomes. Dot plot studies clearly indicate that although ranaviruses share the majority of their genes, gene order is not conserved and may serve as a way to distinguish evolutionarily related isolates or species. For example, gene order is conserved among FV3, tiger frog virus (TFV), and soft-shelled turtle virus, and distinct from that seen with ATV and EHNV (Jancovich et al. 2015).

Phylogenetic analysis using the 26 core genes from completely sequenced ranaviruses has identified four distinct lineages (Fig. 2; Table 1): (1) the TFV/FV3/ BIV-like viruses; (2) the CMTV/ADRV-like viruses; (3) the ATV/EHNV-like viruses; (4) the SGIV/GIV-like viruses. As suggested by analysis of the MCP, SCRV will likely constitute a fifth lineage (Fig. 3; Table 2). Furthermore, as additional ranavirus genomes are sequenced (e.g., especially those present within diverse fish species), it is likely that additional lineages will be added. Ranavirus lineages do not have a clearly defined host range. Lineages include those targeting only fish (e.g., the GIV-like and SCRV-like ranaviruses), only amphibians (e.g., CMTV/ADRV-like ranaviruses), both amphibians and fish (e.g., the ATV/EHNV-like viruses), and amphibians, fish, and reptiles (e.g., TFV/FV3/BIV-like viruses; Fig. 3). Therefore, phylogenetic analyses will enable investigators to identify and classify newly discovered ranaviruses.

Investigators categorize novel ranavirus isolates into viral lineages by sequencing one or more viral genes. For example, phylogenetic analysis and taxonomic classification of newly isolated ranaviruses have focused on a single, highly conserved gene (e.g., the MCP gene; Allender et al. 2013; Duffus and Andrews 2013; Geng et al. 2011; George et al. 2014; Kolby et al. 2014; Marsh et al. 2002; Waltzek et al. 2014), or on a concatenated set composed of multiple viral genes (Holopainen et al. 2009; Iwanowicz et al. 2013). While analysis of the MCP gene is convenient, the highly conserved nature of this protein may mask differences between virus isolates. Collectively, either approach provides a useful starting point to characterize and classify ranavirus isolates. However, having complete genomic sequence information available from a variety of ranavirus isolates will help in developing more rapid, sensitive, and universal approaches for the detection and classification of new ranaviruses. For example, identifying primers that flank hypervariable regions within the genome may allow viral isolates to be more readily distinguished.

There are currently 11 completely sequenced ranaviruses (Table 1). In addition, complete genomic sequence information is available for multiple strains of the same 


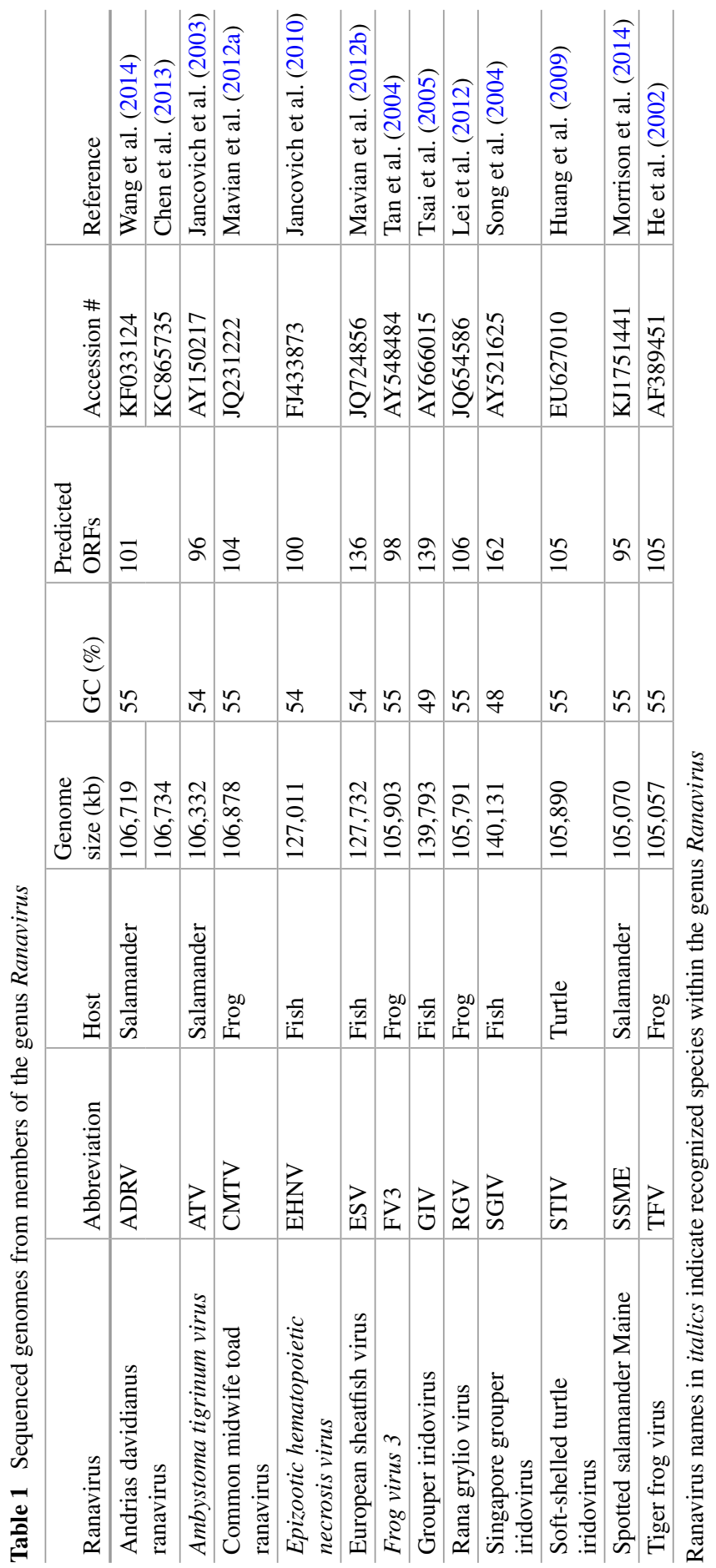




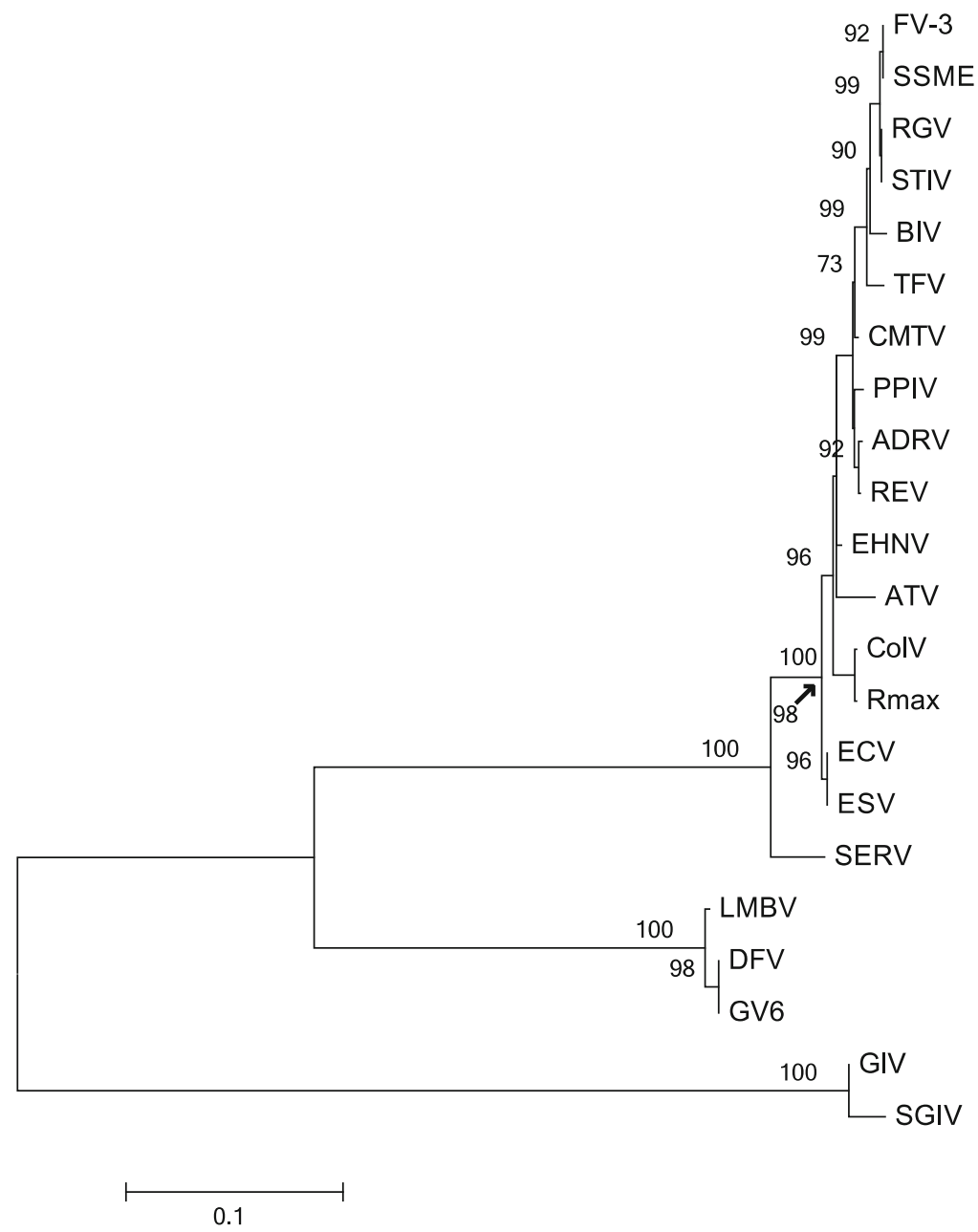

Fig. 3 Phylogram depicting the evolutionary relationships among 22 ranaviruses in the family Iridoviridae, based on the aligned full-length nucleotide (nt) sequences of the major capsid gene. The dataset contained 1,392 aligned nt positions. Maximum likelihood analysis was conducted in MEGA6 (Tamura et al. 2013). Numbers above each node represent the bootstrap values $(1,000$ replicates). See Tables 1 and 2 for taxa abbreviations. Branch lengths are based on the number of inferred substitutions, as indicated by the scale bar

virus (e.g., FV3; Morrison et al. 2014) and closely related viruses (He et al. 2002; Huang et al. 2009; Lei et al. 2012). Comparative dot plot analysis of completely sequenced ranavirus genomes will be discussed in detail in another chapter of this book (Jancovich et al. 2015). That said, there are currently four unique genomic organizations identified among ranavirus genomes (Chen et al. 2013; Eaton et al. 2007; Jancovich et al. 2003, 2010; Mavian et al. 2012a, b; Song et al. 2004; Tan et al. 2004; Tsai et al. 2005). The SCRV group may represent a fifth type 


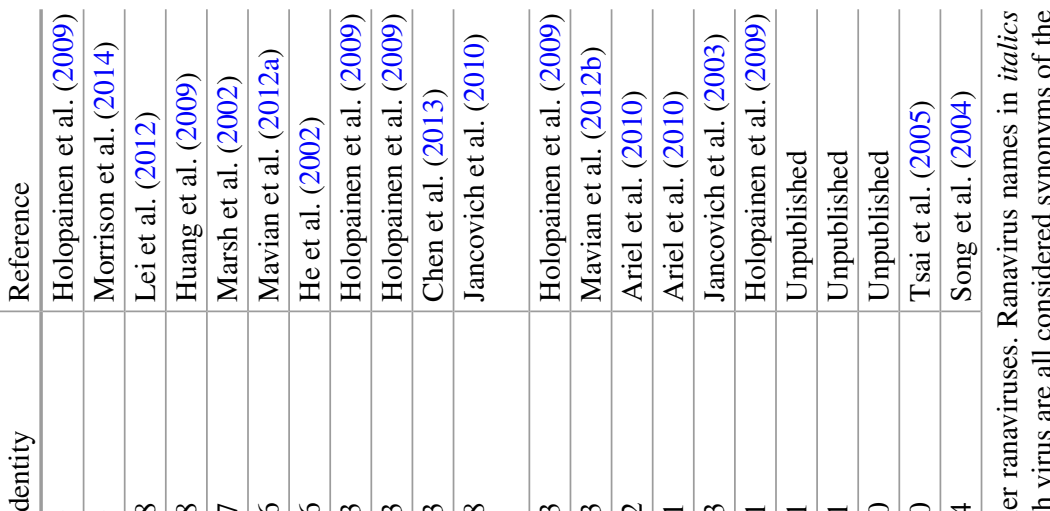

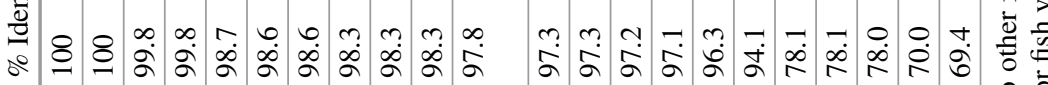
$\dot{\vec{c}}$ 尝 尝

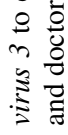

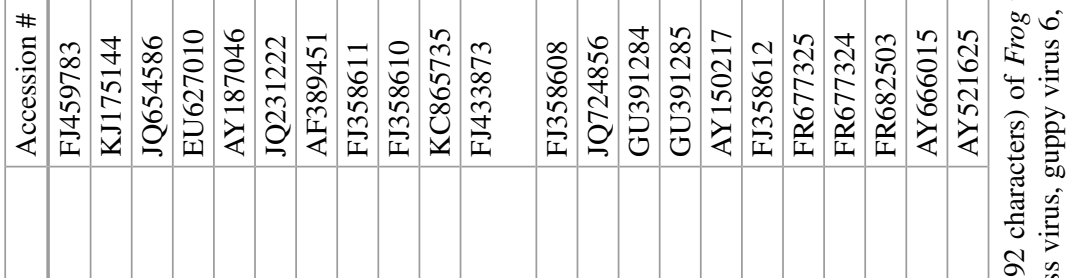

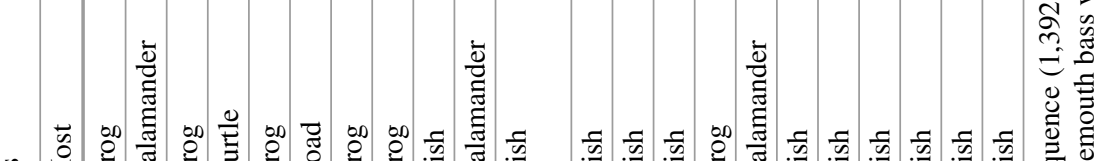

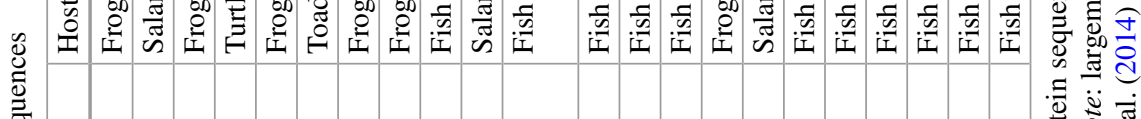

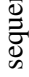

苞

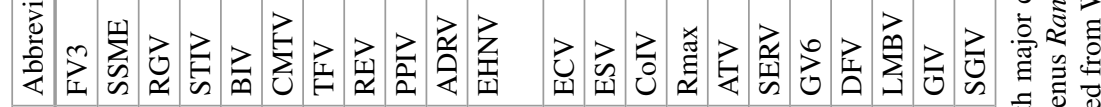

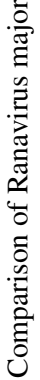

ธี

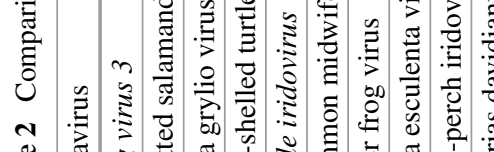

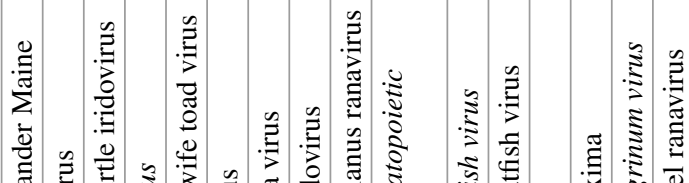

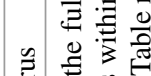

之一

원

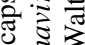

范

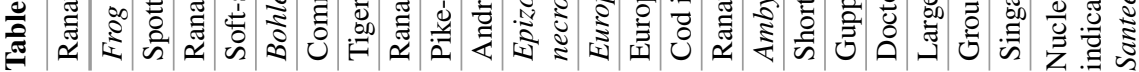


(J.K. Jancovich and T.B. Waltzek, unpublished data), and additional ranavirus genomic organizations may yet to be discovered. Interestingly, whole genome dot plot analyses show that ranaviruses with a similar genomic organization cluster together upon phylogenetic analysis using the 26 core genes. Therefore, there appears to be a direct correlation between ranavirus genomic organization and the 26 gene phylogenies.

It is unclear why there is such diversity in overall genomic architecture among ranaviruses. To that end, no other member of the NCLDV has such a diverse genomic organization. For example, all poxviruses possess genomes that display a conserved central core and variable, inverted terminal repeat regions. The core contains replicative genes common to all poxviruses, whereas the terminal repeat regions encode genes that influence host specificity and pathogenesis (Gubser et al. 2004; Upton et al. 2003). In contrast, although most genes are conserved, gene order differs among the four aforementioned ranavirus lineages. Perhaps the diverse genomic organization is a reflection of their inherently high recombination frequency (Chinchar and Granoff 1986) that leads to marked rearrangement of the viral genome. Therefore, if recombination of the viral genome increases over time, then ranaviruses showing greater sequence divergence may also show lower sequence collinearity. In view of this, future work should focus on understanding this genomic variability and diversity among ranaviruses and its relationship to viral ecology, host range, and pathogenesis.

\section{The Future of Ranavirus Taxonomy: Where Do We Go from Here?}

To envision the future of ranavirus taxonomy, one must first understand how the ICTV defines the different levels of virus taxonomy. The ICTV defines a species as "a monophyletic group of viruses whose properties can be distinguished from those of other species by multiple criteria" (Adams et al. 2013). The criteria for defining a viral species is determined by individual ICTV study groups and may include "natural and experimental host range, cell and tissue tropism, pathogenicity, vector specificity, antigenicity, and the degree of relatedness of their genomes or genes" (Adams et al. 2013). However, the critical component is that a viral species must be defined by "multiple" criteria, not a single distinguishing criterion. In addition, the ICTV recognizes a genus as "a group of species that share certain common criteria" (Adams et al. 2013).

As discussed above, ranavirus taxonomy has been based on RFLP profiles of genomic DNA, virus protein profiles, DNA sequence analysis, and host specificity (Jancovich et al. 2012). Unfortunately, these criteria do not allow us to quantify and differentiate between intraspecific and interspecific diversity in order to delineate one species from another. However, our understanding of ranavirus diversity has significantly increased in recent years through sequence analysis of individual ranavirus genes and sequencing of complete viral genomes. As a result, the Irido- 
viridae Study Group will need to reassess the criteria necessary to assign species and genera within the family. For example, the grouper iridoviruses, GIV and SGIV, appear to be the most distantly related viruses among the current isolates of the genus Ranavirus (Figs. 2 and 3). Whole genome dot plot analysis shows collinearity between the genomes of GIV and SGIV. However, grouper iridoviruses possess few regions of collinearity with other ranaviruses (Jancovich et al. 2015). In addition, GIV/SGIV lack the DNA methyltransferase gene seen among other ranaviruses, and as a result, do not have a methylated genome (Song et al. 2004; Tsai et al. 2005). Therefore, GIV/SGIV may need to be considered as a new genus, or at the very least, recognized as a distinct species in the genus Ranavirus.

Similarly, the SCRV-like ranaviruses, a group that includes doctor fish virus (DFV), largemouth bass virus (LMBV), and guppy virus 6 (GV6), are another collection of related ranaviruses that may also need to be considered as a new genus in the family (Fig. 3). Having the genomic sequence of LMBV would allow for a more complete comparison and may help delineate the taxonomic position of the SCRV group of ranaviruses. We are currently in the process of completing the genomic sequence of LMBV, DFV, and GV6. Once completed, we should be able to perform a more comprehensive analysis of this group of viruses and determine if they should be considered a unique genus in the family Iridoviridae.

Other partially characterized fish ranaviruses include the cod and turbot ranaviruses (Ariel et al. 2010), short-finned eel ranavirus (Holopainen et al. 2009) and pike-perch iridovirus (Tapiovaara et al. 1998). Although preliminary sequencing of the aforementioned viruses has been undertaken (Ariel et al. 2010; Holopainen et al. 2009), full genomic sequencing for these viruses will be needed to determine if they belong in the genus or require the formation of new genera. Therefore, the future of ranavirus taxonomy may reflect the need to "lump" currently recognized species (e.g., ATV/EHNV, TFV/FV3/BIV and CMTV/ADRV) into a single composite species while adding new species (e.g., SGIV/GIV and LMBV/DFV/GV6) or "split" species into distinct genera. To that end, the Iridoviridae Study Group will need to assess the consequences of these possible changes before taxonomic alterations can be finalized.

\section{Final Thoughts}

The taxonomy of ranaviruses is continually evolving, especially as new isolates are discovered worldwide. Taxonomic classification of newly discovered ranavirus isolates has been based on single and multiple viral genes as well as host, protein, serological, and morphological characteristics; however, single-gene taxonomic analysis is unlikely to be as robust as whole genome analysis or phylogenetic comparisons using the 26 core ranavirus genes. As more complete genomic sequences become available, our understanding of the diversity and complexity of ranavirus taxonomy will be delineated. 
Acknowledgments We would like to thank V. Gregory Chinchar and Trevor Williams for their critical review of this manuscript. This work was partially funded by the National Institutes of Health (Award No. 1R15AI101889-01) and California State University San Marcos (J.K.J.); and the University of Florida (N.S. and T.B.W.).

Open Access publication was made possible through grants provided by the University of Tennessee (Institute of Agriculture, Office of Research and Engagement, and Department of Forestry, Wildlife and Fisheries), Washington State University Libraries, Gordon State College (Office of Academic Affairs), the Association of Reptilian and Amphibian Veterinarians, and the Amphibian and Reptile Conservancy.

Open Access This chapter is distributed under the terms of the Creative Commons Attribution Noncommercial License, which permits any noncommercial use, distribution, and reproduction in any medium, provided the original author(s) and source are credited.

\section{References}

Adams MJ, Lefkowitz EJ, King AMQ, Carstens EB (2013) Recently agreed changes to the International Code of Virus Classification and Nomenclature. Arch Virol 158:2633-2639

Allender MC, Bunick D, Mitchell MA (2013) Development and validation of TaqMan quantitative PCR for detection of frog virus 3-like virus in eastern box turtles (Terrapene carolina carolina). J Virol Methods 188:121-125

Ariel E, Holopainen R, Olesen NJ, Tapiovaara H (2010) Comparative study of ranavirus isolates from cod (Gadus morhua) and turbot (Psetta maxima) with reference to other ranaviruses. Arch Virol 155:1261-1271

Brenes R, Gray MJ, Waltzek TB, Wilkes RP, Miller DL (2014) Transmission of ranavirus between ectothermic vertebrate hosts. PLoS One 9: e92476

Chen ZY, Gui JF, Gao XC, Pei C, Hong YJ, Zhang QY (2013) Genome architecture changes and major gene variations of Andrias davidianus ranavirus (ADRV). Vet Res 44:101-114

Chinchar VG, Granoff A (1986) Temperature-sensitive mutants of frog virus 3: biochemical and genetic characterization. J Virol 58:192-202

Colson P, de Lamballerie X, Fournous G, Raoult D (2012) Reclassification of giant viruses composing a fourth domain of life in the new order Megavirales. Intervirology 55:321-332

Colson P, De Lamballerie X, Yutin N, Asgari S, Bigot Y, Bideshi DK, Cheng XW, Federici BA, Van Etten JL, Koonin EV, La Scola B, Raoult D (2013) "Megavirales", a proposed new order for eukaryotic nucleocytoplasmic large DNA viruses. Arch Virol 158:2517-2521

Duffus AL, Andrews AM (2013) Phylogenetic analysis of a frog virus 3-like ranavirus found at a site with recurrent mortality and morbidity events in southeastern Ontario, Canada: partial major capsid protein sequence alone is not sufficient for fine-scale differentiation. J Wildl Dis 49:464-467

Eaton HE, Metcalf J, Penny E, Tcherepanov V, Upton C, Brunetti CR (2007) Comparative genomic analysis of the family Iridoviridae: re-annotating and defining the core set of iridovirus genes. Virol J 4:11-28

Geng Y, Wang KY, Zhou ZY, Li CW, Wang J, He M, Yin ZQ, Lai WM (2011) First report of a ranavirus associated with morbidity and mortality in farmed Chinese giant salamanders (Andrias davidianus). J Comp Pathol 145:95-102

George MR, John KR, Mansoor MM, Saravanakumar R, Sundar P, Pradeep V (2014) Isolation and characterization of a ranavirus from koi, Cyprinus carpio L., experiencing mass mortalities in India. J Fish Dis. doi:10.1111/jfd.12246

Goorha R, Murti KG (1982) The genome of frog virus-3, an animal DNA virus, is circularly permuted and terminally redundant. Proc Natl Acad Sci U S A 79:248-252 
Grayfer L, Edholm E-S, De Jesús Andino F, Chinchar VG, Robert J (2015) Ranavirus host immunity and immune evasion. In: Gray MJ, Chinchar VG (eds) Ranaviruses: lethal pathogens of ectothermic vertebrates. Springer, New York

Gubser C, Hue S, Kellam P, Smith GL (2004) Poxvirus genomes: a phylogenetic analysis. J Gen Virol 85:105-117

He JG, Lu L, Deng M, He HH, Weng SP, Wang XH, Zhou SY, Long QX, Wang XZ, Chan SM (2002) Sequence analysis of the complete genome of an iridovirus isolated from the tiger frog. Virology 292:185-197

Holopainen R, Ohlemeyer S, Schutze H, Bergmann SM, Tapiovaara H (2009) Ranavirus phylogeny and differentiation based on major capsid protein, DNA polymerase and neurofilament triplet H1-like protein genes. Dis Aquat Organ 85:81-91

Huang YH, Huang XH, Liu H, Gong J, Ouyang ZL, Cui HC, Cao JH, Zhao YT, Wang XJ, Jiang YL, Qin QW (2009) Complete sequence determination of a novel reptile iridovirus isolated from soft-shelled turtle and evolutionary analysis of Iridoviridae. BMC Genomics 10: 224-238

Iwanowicz L, Densmore C, Hahn C, McAllister P, Odenkirk J (2013) Identification of largemouth bass virus in the introduced Northern Snakehead inhabiting the Chesapeake Bay watershed. J Aquat Anim Health 25:191-196

Jancovich JK, Mao J, Chinchar VG, Wyatt C, Case ST, Kumar S, Valente G, Subramanian S, Davidson EW, Collins JP, Jacobs BL (2003) Genomic sequence of a ranavirus (family Iridoviridae) associated with salamander mortalities in North America. Virology 316:90-103

Jancovich JK, Bremont M, Touchman JW, Jacobs BL (2010) Evidence for multiple recent host species shifts among the ranaviruses (family Iridoviridae). J Virol 84:2636-2647

Jancovich JK, Chinchar VG, Hyatt A, Myazaki T, Williams T, Zhnag QY (2012) Family Iridoviridae. In: King AMQ (ed) Ninth report of the International Committee on Taxonomy of Viruses. Elsevier, San Diego

Jancovich JK, Qin Q, Zhang Q-Y, Chinchar VG (2015) Ranavirus replication: molecular, cellular, and immunological events. In: Gray MJ, Chinchar VG (eds) Ranaviruses: lethal pathogens of ectothermic vertebrates. Springer, New York

Kolby JE, Smith KM, Berger L, Karesh WB, Preston A, Pessier AP, Skerratt LF (2014) First evidence of amphibian chytrid fungus (Batrachochytrium dendrobatidis) and ranavirus in Hong Kong amphibian trade. PLoS One 9:e90750

Lei XY, Ou T, Zhu RL, Zhang QY (2012) Sequencing and analysis of the complete genome of Rana grylio virus (RGV). Arch Virol 157:1559-1564

Marschang RE (2011) Viruses infecting reptiles. Viruses 3:2087-2126

Marsh IB, Whittington RJ, O'Rourke B, Hyatt AD, Chisholm O (2002) Rapid differentiation of Australian, European and American ranaviruses based on variation in major capsid protein gene sequence. Mol Cell Probes 16:137-151

Mavian C, Lopez-Bueno A, Balseiro A, Casais R, Alcami A, Alejo A (2012a) The genome sequence of the emerging common midwife toad virus identifies an evolutionary intermediate within ranaviruses. J Virol 86:3617-3625

Mavian C, Lopez-Bueno A, Fernandez Somalo MP, Alcami A, Alejo A (2012b) Complete genome sequence of the European sheatfish virus. J Virol 86:6365-6366

Miller D, Gray M, Storfer A (2011) Ecopathology of ranaviruses infecting amphibians. Viruses 3:2351-2373

Morrison EA, Garner S, Echaubard P, Lesbarreres D, Kyle CJ, Brunetti CR (2014) Complete genome analysis of a frog virus 3 (FV3) isolate and sequence comparison with isolates of differing levels of virulence. Virol J 11:46-59

Raoult D, Audic S, Robert C, Abergel C, Renesto P, Ogata H, La Scola B, Suzan M, Claverie JM (2004) The 1.2-megabase genome sequence of Mimivirus. Science 306:1344-1350

Song WJ, Qin QW, Qiu J, Huang CH, Wang F, Hew CL (2004) Functional genomics analysis of Singapore grouper iridovirus: complete sequence determination and proteomic analysis. J Virol 78:12576-12590 
Tamura K, Stecher G, Peterson D, Filipski A, Kumar S (2013) MEGA6: molecular evolutionary genetics analysis version 6.0. Mol Biol Evol 30:2725-2729

Tan WGH, Barkman TJ, Chinchar VG, Essani K (2004) Comparative genomic analyses of frog virus 3, type species of the genus Ranavirus (family Iridoviridae). Virology 323:70-84

Tapiovaara H, Olesen NJ, Linden J, Rimaila-Parnanen E, von Bonsdorff CH (1998) Isolation of an iridovirus from pike-perch Stizostedion lucioperca. Dis Aquat Organ 32:185-193

Tsai CT, Ting JW, Wu MH, Wu MF, Guo IC, Chang CY (2005) Complete genome sequence of the grouper iridovirus and comparison of genomic organization with those of other iridoviruses. J Virol 79:2010-2023

Upton C, Slack S, Hunter AL, Ehlers A, Roper RL (2003) Poxvirus orthologous clusters: toward defining the minimum essential poxvirus genome. J Virol 77:7590-7600

Waltzek TB, Miller DL, Gray MJ, Drecktrah B, Briggler JT, MacConnell B, Hudson K, Hopper L, Friary J, Yun SC, Malm KV, Weber ES, Hedrick RP (2014) New disease records for hatcheryreared sturgeon. I. Expansion of the host range of frog virus 3 into hatchery-reared pallid sturgeon Scaphirhynchus albus. Dis Aquat Organ 111:219-227

Wang N, Zhang M, Zhang L, Jing H, Jiang Y, Wu S, Lin X (2014) Complete genome sequence of a ranavirus isolated from Chinese giant salamander (Andrias davidianus). Genome Announc 2:e01032-e01013

Whittington RJ, Becker JA, Dennis MM (2010) Iridovirus infections in finfish-critical review with emphasis on ranaviruses. J Fish Dis 33:95-122

Yutin N, Koonin EV (2012) Hidden evolutionary complexity of nucleo-cytoplasmic large DNA viruses of eukaryotes. Virol J 9:161-179

Yutin N, Wolf YI, Raoult D, Koonin EV (2009) Eukaryotic large nucleo-cytoplasmic DNA viruses: clusters of orthologous genes and reconstruction of viral genome evolution. Virol $\mathrm{J}$ 6: $223-236$ 


\title{
Ranavirus Ecology and Evolution: From Epidemiology to Extinction
}

\author{
Jesse L. Brunner, Andrew Storfer, Matthew J. Gray, \\ and Jason T. Hoverman
}

\section{Introduction}

Ranaviruses were thought to have little impact on populations of fish and amphibians for decades after their serendipitous discovery in primary kidney cell cultures of northern leopard frogs (Lithobates [formerly Rana] pipiens; Granoff et al. 1966; Chinchar et al. 2009; Williams et al. 2005). This view changed with increasing evidence that ranaviruses were responsible for widespread epidemics and mortality in several fishes and later amphibians (Ahne et al. 1997; Chinchar 2002; Williams et al. 2005). The growing interest in this genus of viruses is fueled by the apparent increases in geographic range, as well as evidence of population declines coming from a wide range of ectothermic vertebrates around the world (Duffus et al. 2015). Ranavirus die-offs in the wild and in captive settings are often marked by a rapid onset and high mortality, but less obvious ranaviral infections in natural populations can occur. Overall, ranavirus epidemics can result in a range of effects on population dynamics, from apparently benign infections to local extirpation. In this chapter, we will review the current status of ranavirus epidemiology, with a particular focus on

\footnotetext{
J.L. Brunner $(\square) \bullet A$. Storfer

School of Biological Sciences, Washington State University,

Pullman, WA 99164, USA

e-mail: jesse.brunner@wsu.edu; astorfer@wsu.edu

M.J. Gray

Center for Wildlife Health, Department of Forestry, Wildlife and Fisheries,

University of Tennessee, 274 Ellington Plant Sciences Building,

Knoxville, TN 37996, USA

e-mail: mgray11@utk.edu

J.T. Hoverman

Department of Forestry and Natural Resources, Purdue University,

West Lafayette, IN 47907, USA

e-mail: jhoverm@purdue.edu 
factors that can influence the outcome of ranavirus infections for individuals and populations. We will then discuss ranavirus transmission within and between species, and its consequences for ranavirus epidemiology. We also consider the evolution of ranaviruses with a focus on local adaptation and virulence, which is important to understand in light of the growing evidence that ranaviruses are being moved around the world by human activities. We end by returning to the impacts of ranaviruses on their hosts, considering whether ranaviruses can cause host extinctions.

\section{Epidemiology of Ranaviruses}

Most of what is known about the epidemiology, geography, and host range of ranaviruses comes from investigations of obvious die-offs, sporadic surveillance efforts in small numbers of populations and time points, and a few larger-scale surveillance efforts focused on a handful of species of economic importance or conservation interest (Grizzle and Brunner 2003; Gray et al. 2009a; Whittington et al. 2010; Miller et al. 2011; Duffus et al. 2015). Duffus et al. (2015) reviewed the known distribution and host range of ranaviruses. In total, six species of Ranavirus are recognized, causing infection or overt disease in at least 175 species (52 families) of ectothermic vertebrates from 32 countries on six continents (Duffus et al. 2015).

\subsection{Ranavirus Epidemiology in Amphibians}

Ranavirus infections and related mortality events have been reported in amphibians from North and South America, Europe, Africa, and Asia (Duffus et al. 2015). In North America, 43-57 \% of amphibian mortality events were attributed to viral infections, presumably ranaviruses (Green et al. 2002; Muths et al. 2006). These epidemics usually occurred in mid-to-late summer and involved late stage tadpoles and recent metamorphs (Fig. 1; Green et al. 2002). Mortality is often sudden, with hundreds or thousands of apparently normal larvae present on one day and $>90 \%$ dead within several days (Fig. 2; Green et al. 2002). In one recent report, at least 200,000 larvae died within just $24 \mathrm{~h}$ (Wheelwright et al. 2014). There are similar reports of rapid, seasonal outbreaks in wild amphibians in Europe (e.g., Ariel et al. 2009a; Kik et al. 2011), South and Central America (Fox et al. 2006; Stark et al. 2014), and Asia (e.g., Une et al. 2009), and widespread reports from captive populations that follow similar patterns (Duffus et al. 2015). Price et al. (2014) recently reported declines in amphibian communities at multiple sites in Spain after the apparent introduction of a novel ranavirus. There are, however, several reports of ranavirus being present in larval and post-metamorphic amphibians without notable disease or mortality (Duffus et al. 2015), although most studies do not collect longitudinal data and are liable to miss mortality events (Gray et al. 2015). It is worth noting that sublethal infections by ranavirus can impact fitness-related traits such as growth and development (Echaubard et al. 2010). 


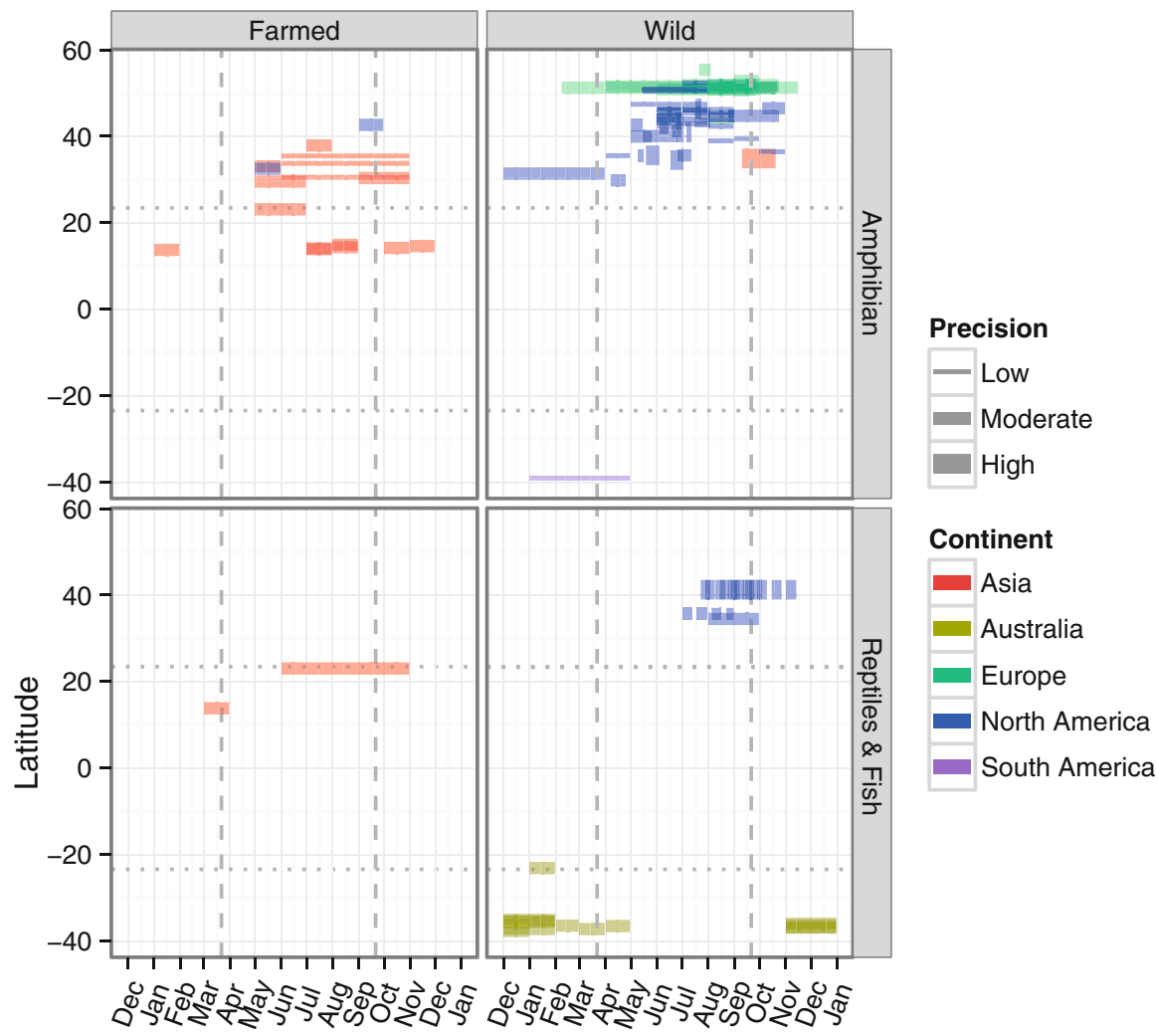

Fig. 1 The seasonal timing of ranavirus die-offs in farmed and wild populations of amphibians, fish, and reptiles (dashed lines) plotted against latitude. Most die-off events begin (and often end) during the summer months. The vertical dashed lines are the equinoxes and the horizontal dashed lines show the tropics of Cancer and Capricorn. The data include 109 events reported in 40 publications that included both the timing and location of the die-off. When only the names of months were provided, we include the entire month(s). If a duration was provided, we adjusted the end dates to match the duration. "Mid" month was assumed to be the 15th. Precision in the description of the dates ranged from low, when only partial information was presented (e.g., the onset, but not end of the event), to high, where precise dates were provided. There is also imprecision in the latitude of many events as reports often provided only county, state, or province data. In these cases, we used the approximate midpoint of the region

In contrast to this general pattern of ranavirus outbreaks in larval amphibians, the ranavirus die-offs in common frogs (Rana temporaria) in the UK seem to be restricted mostly to adult frogs (Cunningham et al. 1993; Teacher et al. 2010; Duffus et al. 2013). Duffus et al. (2013) detected ranavirus in only one of 288 tadpoles collected in one year, but 32 of 120 adults were positive for ranavirus over three years. Population declines in the adult common frogs have been slow, but widespread in the UK (Teacher et al. 2010). 

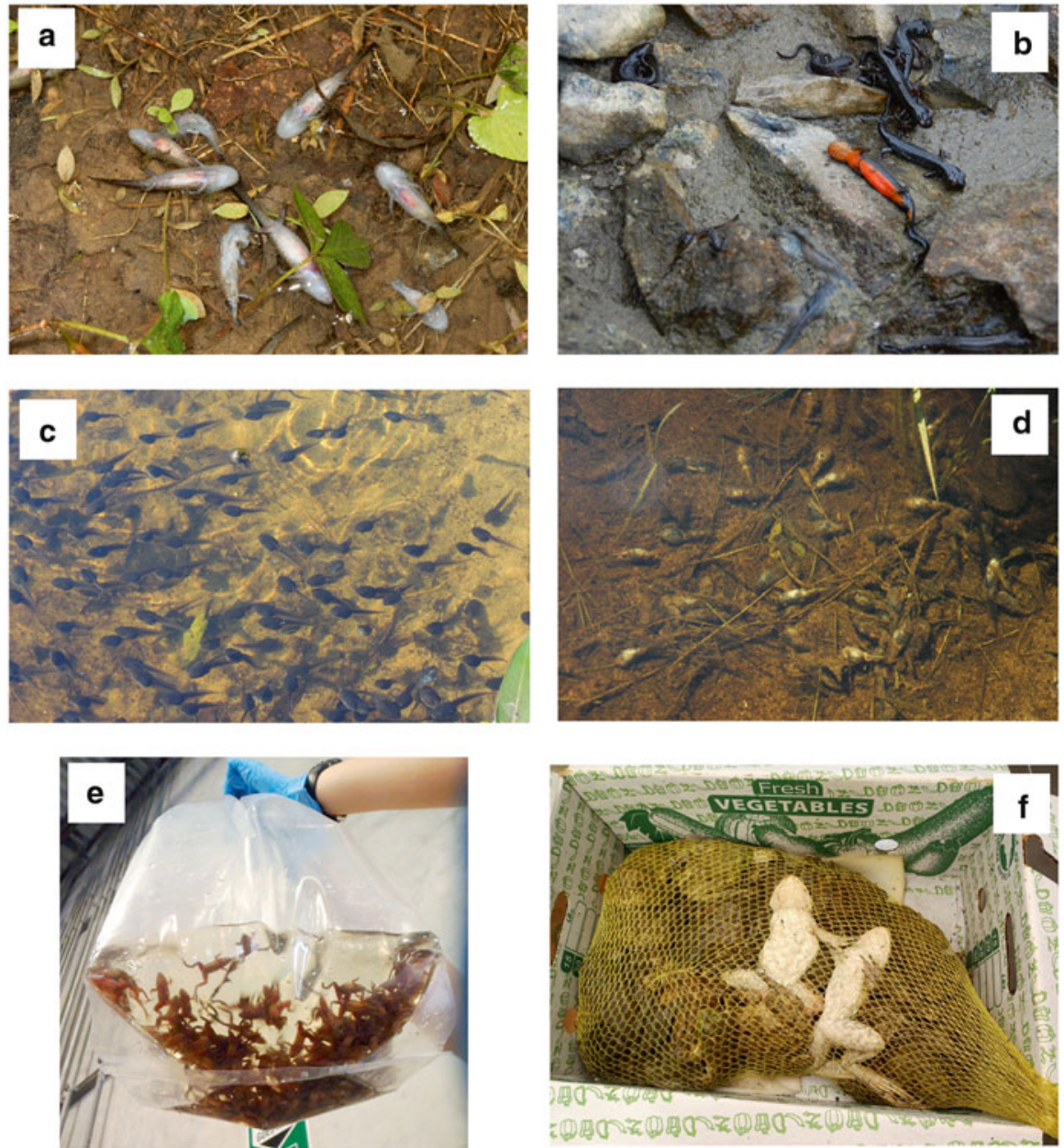

Fig. 2 Ranavirus die-offs can include larval $(\mathbf{a}$, credit=Matthew Niemiller $)$ and adult $(\mathbf{b}$, credit= Ana Balseiro) age classes in amphibians. Outbreaks can occur rapidly progressing from no apparent death $(\mathbf{c}$, credit $=$ Nathaniel Wheelwright $)$ to complete mortality $(\mathbf{d}$, credit $=$ Nathaniel Wheelwright) in a matter of days. Global transport of subclinically infected individuals may be contributing to the emergence of ranaviruses (e, credit $=$ Jonathan Kolby). High contact rates with abundant hosts in captivity and during transport may be resulting in evolution of ranavirus virulence (f, credit $=$ Jonathan Kolby)

\subsection{Ranavirus Epidemiology in Fishes}

Many ranaviruses have been associated with mortality events in cultured fish (e.g., Ahne et al. 1997; Chua et al. 1994; Deng et al. 2011; Langdon et al. 1988; Prasankok et al. 2005; Qin et al. 2003), but the epidemiology and ecology of these aquacultural 
systems is rarely well documented. Most of what is known about the ecology and epidemiology of ranaviruses in fishes comes from studies of Epizootic haematopoietic necrosis virus (EHNV) in Australia and largemouth bass virus (LMBV; a strain of Santee Cooper ranavirus) in the Southeast USA (Whittington et al. 2010). EHNV outbreaks have caused rapid (2-3 weeks) die-offs affecting tens to thousands of juvenile redfin perch (Perca fluviatilis) in the early summer, with a few adults also affected (Langdon et al. 1986; Langdon and Humphrey 1987). In isolated ponds with no prior history of EHNV, die-offs involved mass mortality in adults ( $>1$ year old), suggesting a role of prior exposure or ontogeny. While die-offs are dramatic and have continued over the last 30 years, the frequency with which EHNV epidemics occur is difficult to assess given uncertain detection in deep waters and remote locations (Whittington et al. 2010). EHNV has also caused mortality events in farmed rainbow trout (Oncorhynchus mykiss) in Australia, in which the virus is not very infectious, but can be highly virulent (Langdon et al. 1988; Whittington et al. 1994, 1999).

Most LMBV die-offs occur in the summer and involve large $(>30 \mathrm{~cm})$ largemouth bass (Micropterus salmoides; Grizzle and Brunner 2003). While LMBV is sometimes associated with die-offs of thousands of large fish (Plumb et al. 1996; Hanson et al. 2001) and has been associated with the declines in larger, older largemouth bass noted in the 1990s in some lakes (Maceina and Grizzle 2006), the incidence of diseased or dying fish is often too low to be noticed (Grizzle and Brunner 2003). Moreover, LMBV is often found in clinically normal animals and at sites with no (observed) history of die-offs (Hanson et al. 2001; Grizzle et al. 2002; Grizzle and Brunner 2003). If there is a common theme to the epidemiology of these two fish ranaviruses, it is that epidemics primarily involve certain susceptible life history stages (EHNV in juveniles and LMBV in adults) during stressful conditions (e.g., warm periods).

Because they represent a distinct phylogenetic lineage within the genus Ranavirus (Qin et al. 2003; Huang et al. 2011), it is worth mentioning the Grouper iridovirus (GIV) and Singapore grouper iridovirus (SGIV). These viruses have caused significant mortality and losses in groupers (Epinephelus spp.) and other finfish in mariculture since the mid-1990s in Southeast Asia (Chua et al. 1994; Qin et al. 2003; Harikrishnan et al. 2010). Few details of the epidemiology of this virus have been reported, but epidemics occur over several weeks (Nagasawa and Cruz-Lacierda 2004), cause up to $90 \%$ mortality, and stress (e.g., handling stress, water quality) may play a role in magnifying clinical signs and mortality (Chua et al. 1994).

\subsection{Ranavirus Epidemiology in Reptiles}

In reptiles, ranavirus infections have been detected sporadically, primarily in rehabilitation facilities and other captive settings (Ariel 2011; Allender et al. 2013a; Chinchar and Waltzek 2014). While several outbreaks in free-ranging chelonians have been observed (Allender et al. 2006; Johnson et al. 2008; Belzer and Seibert 
2011; Farnsworth and Seigel 2013), there are no similar reports of ranaviruses in free-living populations of other reptile taxa. Unlike in fish and amphibians, ranavirus outbreaks in chelonians, at least in North America, are more diffuse. Mortalities are observed over the entire active season (i.e., when turtles are not hibernating in winter), often for several years (Belzer and Seibert 2011; Farnsworth and Seigel 2013). Most cases, however, are noted in the summer months (Fig. 1). The available evidence suggests that ranaviruses cause an acute, rapidly lethal infection in chelonians (Johnson et al. 2007). Most individuals that are infected will die within several weeks, so the prevalence of infection at any given point in time is low. For instance, 15 of $71(21 \%)$ free-ranging eastern box turtles (Terrapene carolina carolina) died during a ranavirus die-off at a private nature sanctuary in Pennsylvania, USA (Johnson et al. 2008; Belzer and Seibert 2011). The following year only one of the 55 surviving turtles was seropositive, strongly suggesting that the vast majority of infected individuals died (Johnson et al. 2010). Similarly, Allender et al. (2013a) found that the prevalence of ranavirus infection was very low $(1 / 309 ; 0.3 \%)$ over 3 years in free-ranging eastern box turtles in Tennessee, USA. The seroprevalence of free-ranging gopher tortoises (Gopherus polyphemus) from five states in the southeastern USA was also low (1.5\%; Johnson et al. 2010), which is consistent with a highly virulent, acute infection. There is some evidence that ranavirus infections in more aquatic turtles may be less pathogenic (Sect. 7). Consistent with this hypothesis, ranavirus prevalence was higher $(11 / 63 ; 17 \%)$ in highly aquatic eastern painted turtles (Chrysemys picta picta) in Virginia, USA (Goodman et al. 2013).

Based on the available information, it appears unlikely that the sporadic mortality events in chelonians are caused by self-sustaining ranavirus epidemics. Ranaviruses infections in chelonians are acute and often lethal, which provides little time for infected turtles to contact naïve turtles. Moreover, most chelonian populations exist at low densities, which further limits opportunities for transmission. These die-offs therefore likely occur from spillover of ranavirus infections from other species.

\subsection{Summary of Ranavirus Epidemiology}

While there is still a great deal of uncertainty surrounding ranavirus epidemiology in natural populations, two patterns are apparent. First, there appears to be a common temporal pattern to ranavirus epidemics or mortality events, at least in fish and amphibians (Fig. 1). Die-offs have a rapid onset, generally in the summer months, and often progress rapidly, although there are important exceptions to this pattern (e.g., bullfrog [Lithobates catesbeianus (formerly Rana catesbeiana)] die-offs in Japan and the American Southeast have been noted in October; Hoverman et al. 2012; Une et al. 2009). Second, there is a great deal of variability in the outcome of ranavirus epidemics between populations and locations, from no (apparent) mortality to die-offs with few survivors. In the next sections, we explore several hypotheses for these patterns, beginning with the timing of epidemics. 


\section{Explanations for the Apparent Seasonality of Ranavirus Epidemics}

Ranavirus epidemics often occur during late spring or summer and can begin and end within weeks (Langdon and Humphrey 1987; Green et al. 2002; Grizzle and Brunner 2003). There are four non-mutually exclusive hypotheses that might explain the apparent seasonality and rapidity of observed ranavirus die-offs. First, this pattern may be spurious, resulting from a detection bias. Second, the die-offs may simply reflect the underlying epidemic dynamics following the introduction of ranavirus into populations earlier in the year. Third, hosts may become more susceptibility to ranavirus infections at certain development stages that coincide with the summer months. Lastly, these events may occur when temperatures rise in the summer. In the following sections, we evaluate these hypotheses and their underlying mechanisms.

\subsection{Detection Biases}

The frequent observation that ranavirus die-offs involve metamorphosing amphibians and late stage larvae (Green et al. 2002) may simply be an artifact of metamorphs moving to shallow water to complete metamorphosis where they are more easily observed. Similarly, large numbers of juvenile fish tend to cluster near shores frequented by people, which contributed to the first detection of EHNV in redfin perch (Whittington et al. 2010). Die-off events in remote locations, at times when people are not active, and in cryptic species may go unnoticed. For example, morbidity and mortality of turtles due to ranavirus may be often missed given the secretive nature of these animals (Farnsworth and Seigel 2013). However, many ranavirus outbreaks that fit the general pattern of rapid onset of mortality in the summer have been observed in well-studied, frequently visited populations (e.g., Brunner et al. 2011; Langdon and Humphrey 1987; Petranka et al. 2007; Wheelwright et al. 2014), suggesting that detection biases are not a general explanation for the observed timing of mortality events.

\subsection{Seasonal Introductions and Incidence of Ranavirus Infection}

The rapid onset and seasonality of ranavirus die-offs may simply reflect a rapid increase in the incidence of infections following the introduction of virus earlier in the year. One hypothesis is that ranavirus epidemics in amphibians begin when sublethally infected adults return to sites to breed (Brunner et al. 2004). Adults might transmit infections directly to larvae of the same or other species if they overlap in 
space and time, or indirectly if they die from a recrudescent infection and are consumed by feeding larvae. Brunner et al. (2004) found that some adult tiger salamanders (Ambystoma mavortium [formerly tigrinum] nebulosum) in the southwestern USA returning to breeding sites were infected with Ambystoma tigrinum virus (ATV). Similarly, a recent survey found that $39 \%$ of male wood frogs (Lithobates [Rana] sylvaticus) in the eastern USA returning to breeding sites harbored subclinical infections (JLB, E. J. Crespi, and S. Hall, Washington State University; S. Duncan, N.M. Mattheus, and L. Rissler, University of Alabama, unpublished data). Spillover from adults or carcasses could spark subsequent larval epidemics. Thus, the dynamics of ranavirus infection may be similar to those of many other infectious diseases (Keeling and Rohani 2008), spreading slowly after introduction because the infection is rare and accelerating as the epidemic builds. Because ranavirus infections in amphibians are often lethal, usually within days to weeks of exposure in laboratory challenges (Gray et al. 2009a; Hoverman et al. 2011), one would expect mortality to track infection with some relatively short delay. The actual time course of mortality in the wild may appear more rapid simply because those few individuals dying earlier in an epidemic are difficult to detect because they are small, decompose quickly, or are scavenged. Only when there are many dead animals (and perhaps the scavengers are sated) does the event become obvious. Moreover, an accumulation of infectious carcasses may facilitate transmission (Pearman et al. 2004; Harp and Petranka 2006; Brunner et al. 2007), increasing the speed of the epidemic. There is some support of this hypothesis in amphibians. Todd-Thompson (2010) observed a typical epidemic curve in her longitudinal survey for ranaviruses in an amphibian community inhabiting a depressional wetland in the southern Appalachian Mountains of the USA. Ranavirus was not detected until late April, when $20 \%$ of the larvae were infected and increased to a high of $80 \%$ twenty days later, which coincided with a die-off of ambystomatid larvae. The rapid increase in the prevalence of infection signs in spotted chorus frog (Pseudacris clarkii) tadpoles collected by Torrence et al. (2010) is also consistent with this model. Indeed, mortality events generally coincide with high infection prevalence (Bollinger et al. 1999; Greer et al. 2005; Fox et al. 2006; Kik et al. 2011; Hoverman et al. 2012; Homan et al. 2013; Titus and Green 2013).

In some ranavirus-host systems, infection prevalence may be uncorrelated with the occurrence of disease. Greer et al. (2009), for instance, found that ATV infection in tiger salamanders (A. m. nebulosum) increased to a peak of $\sim 50 \%$ prevalence in three ponds in northern Arizona, but no morbidity or mortality was observed. Similarly, Duffus et al. (2008) found that 20-32\% of wood frog tadpoles were infected in early summer, but none showed clinical signs of disease. LMBV is also commonly found in the absence of morbidity or mortality (Hanson et al. 2001; Grizzle and Brunner 2003; Groocock et al. 2008; Southard et al. 2009). It is thus important to collect both epidemiological and demographic data on host populations at multiple time points to understand the effects of ranaviruses on their host populations (Gray et al. 2015). 


\subsection{Susceptibility Throughout Development}

In addition to the frequent observation that juveniles are more susceptible to ranavirus infections than adults (Cullen et al. 1995; Ariel 1997; Cullen and Owens 2002; Bang Jensen et al. 2011b), hosts may become vulnerable to ranavirus infections at certain development stages that coincide with the summer months. In amphibians, die-off events from ranaviruses have often been reported in individuals near to or undergoing metamorphosis (Speare and Smith 1992; Green and Converse 2005; Greer et al. 2005). Amphibian metamorphosis is energetically costly and entails a period of natural immunosuppression (Rollins-Smith 1998; Carey et al. 1999). Metamorphosing anurans are hypothesized to be particularly vulnerable to ranavirus infection. This might explain both the occurrence of ranavirus die-offs in amphibians in the summer and their speed (e.g., Gahl and Calhoun 2010). Warne et al. (2011) found that the odds of death in wood frog tadpoles exposed to ranavirus increased 1.7-fold with each increase in Gosner (1960) development stage. Higher susceptibility of wood frog larvae to ranavirus later in development was supported by an epidemiological model that correctly predicted the timing of mortality events in summer using stage-specific susceptibility (Fig. 3; Warne et al. 2011). If all stages were equally susceptible, mortality in wood frog populations would occur in spring, which was not observed. Haislip et al. (2011) also found that susceptibility to ranavirus differed among amphibian developmental stages, but metamorphosis was not always the most susceptible stage. Thus, the occurrence of metamorphosis is not a universal explanation for timing of ranavirus outbreaks in amphibian communities.

\subsection{Temperature and Susceptibility}

Higher temperatures during summer may be another factor contributing to the timing of ranavirus outbreaks. Grizzle and Brunner (2003) hypothesized that the occurrence of LMBV die-offs in the summer was driven by increased susceptibility of largemouth bass to infection at higher temperatures or other temperature-related stressors (e.g., low oxygen concentrations, Goldberg 2002), which was supported by experimental challenges (Grant et al. 2003). The occurrence of EHNV epidemics in redfin perch in the early summer, primarily in juveniles (Langdon 1989), may also be related to the effects of temperature on susceptibility. Juvenile perch feed in shallow, warmer waters in the early summer, which promotes EHNV infection and disease (Whittington and Reddacliff 1995; Ariel et al. 2009b), while adults feed in deeper, cooler waters and may thus avoid or clear infections (Whittington and Reddacliff 1995; Whittington et al. 2010). Outbreaks of ENHV in rainbow trout in Australia do not appear to be associated with temperature, but rather with poor husbandry and high stocking densities (Whittington et al. 1999, 2010).

Temperature can influence both the kinetics of host-parasite interaction and act as a stressor to hosts. First, the replication rates of pathogens and the kinetics of the 
a
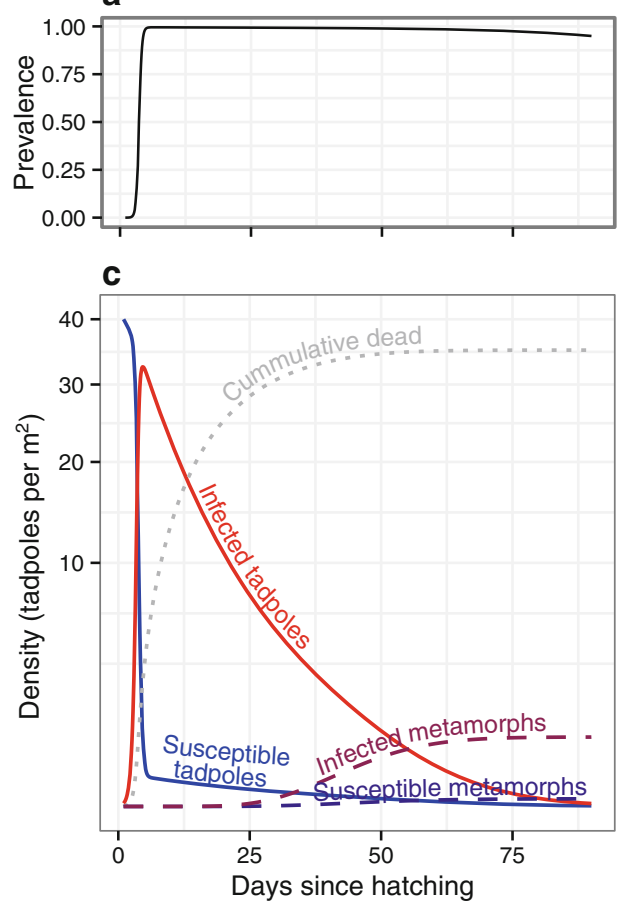

b

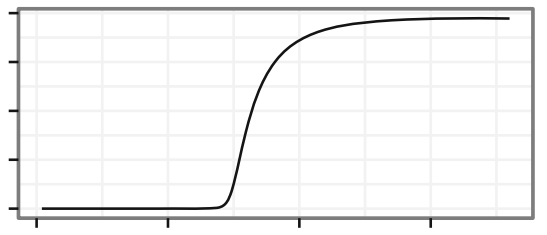

d

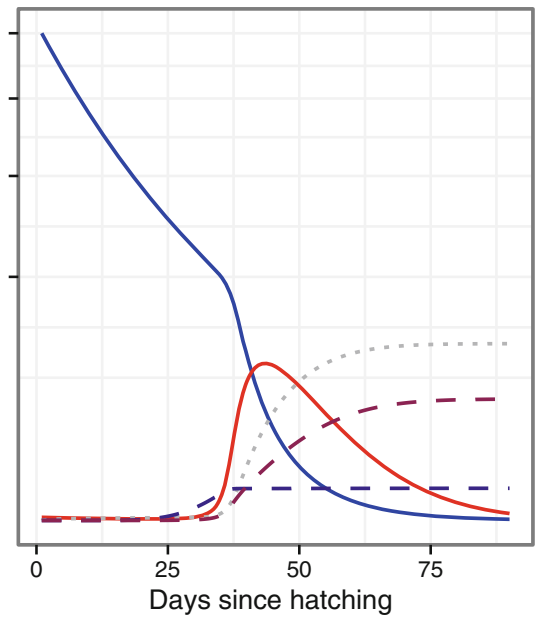

Fig. 3 The prevalence $(\mathbf{a}, \mathbf{b})$ and dynamics $(\mathbf{c}, \mathbf{d})$ of a susceptible-infected-susceptible (SIS) model of ranavirus epidemics in a population of developing wood frog tadpoles that assumes all tadpoles are equally susceptible $(\mathbf{a}, \mathbf{c})$ or that tadpoles become more susceptible to infection as they approach metamorphosis $(\mathbf{b}, \mathbf{d})$. The model includes a constant background mortality rate of 0.04 per day (estimated from DeBenedictis 1974) and a development rate of 0.25 stages per day from Gosner (1960) stage 20 (hatching) to 41 (metamorphosing), which equates to an average larval period of 60 days. The transmission rate was estimated from experimental epidemics in mesocosms with wood frog tadpoles (JLB, Washington State University, unpublished data). The initial density of hatchling tadpoles is 40 per $\mathrm{m}^{2}$, which is at the low end of the natural range of densities (e.g., 26-790 per $\mathrm{m}^{2}$; Petranka et al. 2003), but the results do not qualitatively change at 400 per $\mathrm{m}^{2}$. Estimates of the rates at which infected animals die ( 0.0331 per day) or recover $(0.0169$ per day) were from Reeve et al. (2013). Note that recovered tadpoles become susceptible again in this model, as we have no evidence of immune memory in these tadpoles. Stage-specific susceptibility was included by multiplying the transmission term by the Gosner stage-specific odds of becoming infected, which was estimated in an $\mathrm{LD}_{50}$ study in Warne et al. (2011)

host's immune responses can be temperature sensitive (Altizer et al. 2013). Ariel et al. (2009b) reported that ranavirus replication rates in cell culture increased with temperature up to some optimum, which varied by virus isolate and cell line, but generally was between 24 and $28{ }^{\circ} \mathrm{C}$. However, the short-finned eel ranavirus (SERV) isolated from a coldwater eel replicated best at $20{ }^{\circ} \mathrm{C}$ or lower, suggesting adaptation to its host's environment (Ariel et al. 2009b). Grant et al. (2003) also found some evidence for a host-specific temperature profile in LMBV replication. 
While LMBV grew slightly faster at $30{ }^{\circ} \mathrm{C}$ than $25^{\circ} \mathrm{C}$, it did not replicate past one day in cell culture when held at $35^{\circ} \mathrm{C}$, probably because largemouth bass typically inhabit aquatic systems that do not exceed $30^{\circ} \mathrm{C}$ (Eaton and Scheller 1996; Grant et al. 2003). Thus, there is strong evidence that ranavirus replication is highly temperature- and host-dependent (Speare and Smith 1992; Grant et al. 2003; Rojas et al. 2005; Ariel et al. 2009b).

To the extent that replication in vitro represents replication rates in vivo, we would expect that the rates of viral replication and host mortality would generally increase with temperature. Results from several studies are consistent with this hypothesis. In experimental water bath challenges of adult redfin perch, all of the fish held at water temperatures of $12-21{ }^{\circ} \mathrm{C}$ died, while those at $6-10{ }^{\circ} \mathrm{C}$ either did not become infected or quickly cleared the infection (Whittington and Reddacliff 1995). Experimental challenges of European stocks of redfin perch and rainbow trout with EHNV also found that mortality increased with temperature (from 15 to $20^{\circ} \mathrm{C}$ ), and significant mortality was not observed at $10^{\circ} \mathrm{C}$ (Ariel and Jensen 2009). Similarly, Bayley et al. (2013) reported $>96 \%$ mortality of the common frog tadpoles exposed to ranaviruses (FV3 [Frog virus 3] or REV [Rana esculenta virus]) at $20{ }^{\circ} \mathrm{C}$ but $<32 \%$ when exposed to ranaviruses at $15^{\circ} \mathrm{C}$. A contrasting pattern was observed in a study conducted with larval tiger salamanders and ATV (Rojas et al. 2005). Larvae exposed to ATV and reared at 10 or $18{ }^{\circ} \mathrm{C}$ experienced $>80 \%$ mortality, while larvae reared at $26{ }^{\circ} \mathrm{C}$ experienced $<38 \%$ mortality. Viral titers were higher in salamanders that died at $10^{\circ} \mathrm{C}$ than $18^{\circ} \mathrm{C}$, suggesting that colder temperature may have suppressed immune responses to ATV. There is also evidence in turtles that temperature influences the outcome of infection. Red-eared sliders (Trachemys scripta elegans) infected with FV3 experienced $100 \%$ mortality at $22{ }^{\circ} \mathrm{C}$ but $50 \%$ mortality at $28{ }^{\circ} \mathrm{C}$ (Allender et al. 2013b). Additionally, time to death was shorter and viral loads greater in turtles at $22{ }^{\circ} \mathrm{C}$ compared to those at $28^{\circ} \mathrm{C}$. Allender et al. (2013b) hypothesized that cell-mediated or humoral immune responses could be enabling turtles to clear infections at higher temperatures.

Instead of focusing on the kinetics of viral replication and host immune responses, temperature could be a stressor in and of itself. Bayley et al. (2013) found greater mortality in $R$. temporaria tadpoles held at $20{ }^{\circ} \mathrm{C}$ than at $15{ }^{\circ} \mathrm{C}$ when exposed to FV3, PPIV (Pike perch iridovirus), and REV, but mortality was also greater at $20^{\circ} \mathrm{C}$ in the unexposed control animals, suggesting that the higher temperature was generally stressful. Several fish challenges have shown increased mortality at temperatures near the fishes' thermal limits (Whittington and Reddacliff 1995; Grant et al. 2003). Ariel and Jensen (2009) noted that mortality in rainbow trout exposed to EHNV was highest at $20^{\circ} \mathrm{C}$, which is beyond the natural temperature range for this species and likely stressful or immunosuppressive. The redfin perch in their study, however, experienced the greatest mortality at intermediate temperatures-twice as much at $15{ }^{\circ} \mathrm{C}$ than $20^{\circ} \mathrm{C}$, and very little at $10{ }^{\circ} \mathrm{C}$-so temperature-induced stress appears not to be important in this species. Perhaps viral replication was favored at $15^{\circ} \mathrm{C}$ more than the host's immune system, whereas the immune system was dominant at $20^{\circ} \mathrm{C}$ (Ariel and Jensen 2009). Similarly, Echaubard et al. (2014) found that the rate of mortality in experimental epidemics with northern leopard frog and wood 
frog tadpoles was greater at $14{ }^{\circ} \mathrm{C}$ than at $22{ }^{\circ} \mathrm{C}$ in control populations and those exposed to two FV3-like ranaviruses, providing additional evidence that temperature can influence ranavirus epidemics, but likely depends on the host and type of virus (Echaubard et al. 2014). In conclusion, there are likely multiple mechanisms through which temperatures can influence ranavirus infections. Given the predicted increases in global temperature with climate change, a greater focus on understanding the interactive effects of temperature and its variability (and even temperature variability; e.g., Raffel et al. 2006; but see Terrell et al. 2013) on host and pathogen physiology is needed (Altizer et al. 2013).

\section{Susceptibility in the Face of Other Natural and Anthropogenic Stressors}

One of the perplexing characteristics of ranavirus epidemics is the variation in the outcome, from no (apparent) mortality to massive die-offs. This apparent "randomness" has led to the hypothesis that environmental factors, which can vary a great deal in space and time, may play an important role in disease outbreaks (Gray et al. 2009a). Natural and anthropogenic stressors are broadly thought to suppress immune function, making individuals in stressful environments more susceptible to infection and disease (reviewed in Martin 2009; Blaustein et al. 2012). Although many researchers use the term "stress" to mean any aversive, generally unpredictable condition that would seem to challenge the organisms, there is a physiological basis to the "stress-induced susceptibility" hypothesis. It posits that chronically elevated levels of glucocorticoid "stress" hormones have negative impacts on the immune system, such as reducing circulating lymphocyte populations, decreasing cytokine production, or suppressing cell-mediated immune responses (Sheridan et al. 1994; Haddad et al. 2002; Dhabhar 2009).

Defining stress and identifying stressors and the responses they elicit a priori, however, is often difficult, particularly in the absence of detailed information on the environmental, developmental, and evolutionary context of the organisms (Martin 2009). For example, Warne et al. (2011) found that pro-metamorphic wood frog tadpoles challenged with a ranavirus had elevated glucocorticoid concentrations relative to controls and also experienced faster development and more rapid weight loss. As glucocorticoids are responsible for mobilizing resources (e.g., to respond to infection) as well as accelerating metamorphosis in pro-metamorphic tadpoles, the authors hypothesized that this surge in glucocorticoids led to an energetic trade-off. Only those individuals with large enough energetic reserves could support rapid development and a robust immune response at the same time (Warne et al. 2011). Clearly, linking elevated glucocorticoid concentrations to immunocompetence is fraught with difficulties, even with considerable context. It is thus not surprising that the reported effects of natural and anthropogenic stressors on host susceptibility to ranaviruses are highly variable. 


\subsection{Predators and Other Natural Stressors}

Decades of research, especially in amphibians, have demonstrated that predators can alter the physiology, behavior, and morphology of individuals and populations (Tollrian and Harvell 1999). The threat of predation can alter the production of the stress hormone corticosterone in tadpoles (Fraker et al. 2009), and thus presumably their immunocompetence. Recently, several studies have examined the influence of predation risk on disease outcomes using caged predators, which emit chemical cues (i.e., kairomones), but prevent the predator from contacting and killing the prey. Kerby et al. (2011) found that infection prevalence and mortality increased in ATVexposed larval tiger salamanders when exposed to chemical cues from larval dragonfly predators (Anax junius) compared to controls. However, Haislip et al. (2012) found no effect of predator cues on mortality or infection in a similar set of experiments with four species of larval anurans (L. clamitans, L. sylvaticus, P. feriarum, and Hyla chrysoscelis) and two predator species (Anax sp. and Belostoma flumineum). Similarly, Reeve et al. (2013) found no effect of caged predators (dytiscid beetle larvae and dragonfly larvae) on mortality rates of wood frog tadpoles in laboratory or mesocosm experiments. In this experiment, glucocorticoid concentrations did not differ between the control and predator cue treatments, suggesting either that predator stress does not universally elevate corticosterone production or that the effect dissipates with time. Thus, it seems that predators do not make anuran larvae more susceptible to ranavirus infection, although studies with additional species would be helpful. In addition, although other putative stressors, such as food-level reductions significantly increased glucocorticoid concentrations, tadpoles were not more likely to become infected or experience ranavirus-induced mortality (Reeve et al. 2013). Thus even energetically challenged, physiological stressed amphibians may not be more susceptible to ranaviruses.

\subsection{Anthropogenic Stressors}

It has been hypothesized that anthropogenic stressors may have a stronger impact on ranaviral disease than natural stressors (Reeve et al. 2013). Indeed, many emerging infectious diseases have been linked to human activity, including land-use change and pollution (Daszak et al. 2001). St-Amour et al. (2008) found that the prevalence of ranavirus infection in green frog (Lithobates [Rana] clamitans) populations increased with proximity to industry and human housing, although the mechanisms were unclear. Several studies have found increased ranavirus prevalence in wetlands used by cattle, which were attributed to reductions in emergent vegetation, resulting in greater clustering of amphibian larvae, and decreased water quality (Gray et al. 2007; Greer and Collins 2008; Hoverman et al. 2012). Gahl and Calhoun $(2008,2010)$ found that the probability of ranavirus outbreaks increased, albeit weakly, in ponds with higher concentrations of aluminum ions, low levels of 
calcium, higher temperatures, and those at higher elevation in the watershed. A long-term study in the Great Smoky Mountains National Park, USA, found that ranavirus prevalence was greater in plethodontid salamanders at lower elevation, which the authors attributed to higher water temperature, greater human access, and possibly downstream flow of virions (Gray et al. 2009b; Sutton et al. 2014). Despite these intriguing results from correlational studies, there is a need for experimental studies that investigate the relative importance of anthropogenic stressors and identify the underlying mechanisms.

Pesticides are another anthropogenic factor that may influence the likelihood of developing ranaviral disease. Aquatic systems can receive pesticides from direct application, terrestrial runoff, or windborne drift (Davidson et al. 2002). Moreover, many pesticides have immunosuppressive effects on wildlife (Marcogliese and Pietrock 2011). Larval tiger salamanders exposed to the herbicide atrazine had reduced peripheral leukocyte counts and experienced increased susceptibility to ATV infection (Forson and Storfer 2006b). The insecticides chlorpyrifos and carbaryl also increased mortality of ATV-exposed tiger salamanders (Kerby and Storfer 2009; Kerby et al. 2011). However, Forson and Storfer (2006a) found that atrazine in the water reduced ATV infection in larval long-toed salamanders (Ambystoma macrodactylum). The authors hypothesized that the pesticide may have inactivated the virus or that the pesticide stimulated the immune system of the host. In all four studies, exposure to pesticides and ranavirus occurred simultaneously. Because the immunosuppressive effects of pesticides can take several days to manifest, experimental designs that initiate pesticide exposure prior to virus addition may reveal more consistent outcomes.

\section{Ranavirus Transmission Within a Species}

Ranaviruses can be transmitted by contact with infected individuals, through the water or on fomites (e.g., pond substrates), and by consuming part or all of infected animals (Langdon et al. 1988; Reddacliff and Whittington 1996; Jancovich et al. 1997; Plumb and Zilberg 1999b; Woodland et al. 2002b; Pearman et al. 2004; Harp and Petranka 2006; Brunner et al. 2007; Cunningham et al. 2007a; Robert et al. 2011; Brenes et al. 2014a). Viral mRNA is detectable in the intestines of larval and adult African clawed frogs (Xenopus laevis) as early as $3 \mathrm{~h}$ after exposure to virus in water and then spreads to other tissues, suggesting that the intestines are a primary point of entry of waterborne virus in amphibians (Robert et al. 2011). The skin may not be a common site of infection in metamorphosed amphibians because they secrete antimicrobial peptides on their skin, which can inactivate several types of pathogens, including FV3 and ATV (Chinchar et al. 2001, 2004; Sheafor et al. 2008; Rollins-Smith 2009). Brunner et al. (2007), however, demonstrated that a 1 s skinto-skin contact out of water was sufficient for transmission of ATV from infected, symptomatic tiger salamander larvae to uninfected larvae, so entry through the epithelium is possible at least during the larval stage. 
We suspect that consuming infected tissues is a common and important route of transmission in amphibian larvae. Cannibalism is common in amphibians and reptiles (Crump 1983; Polis and Myers 1985). Even anuran tadpoles engage in cannibalism and scavenging (Altig et al. 2007). Two studies found that wood frog and Italian agile frog (Rana latastei) tadpoles had greater mortality rates when allowed to scavenge dead FV3-infected conspecifics (Pearman et al. 2004; Harp and Petranka 2006). Similarly, Brunner et al. (2007) found that ATV-infected tiger salamander larvae were most infectious near or after death when they could be easily consumed.

The absence of gastrointestinal lesions in fish intraperitoneally injected with EHNV but their occurrence in naturally infected fish suggests an oral route of infection in nature (Langdon et al. 1988; Reddacliff and Whittington 1996). The LMBV is also transmissible through the water (Plumb and Zilberg 1999b) and by consuming infected prey (Woodland et al. 2002a). Transmission by direct contact may also be possible, as LMBV has been detected in cutaneous mucus (Woodland et al. 2002b). In an experiment by Grant et al. (2005), LMBV was transmitted from infected to naïve fish in small aquaria nearly as efficiently when direct contact was prevented as when it was allowed, suggesting that transmission through water is the dominant route. One caveat is that while outbreaks of LMBV disease primarily involve adults, most transmission studies used juvenile fish.

The route of transmission to chelonians is less clear. Johnson et al. (2007) could only induce infections in a box turtle (Terrepene ornata ornata) and several redeared sliders with intramuscular injections of Burmese star tortoise ranavirus, but those that were orally exposed to the same dose remained uninfected. More recently, however, Brenes et al. (2014a) demonstrated water-borne transmission of an FV3like ranavirus isolated from pallid sturgeon (Scaphirhynchus albus; Waltzek et al. 2014) to red-eared sliders: $20 \%$ of turtles that were bath exposed and $30 \%$ of turtles co-housed with infected Cope's gray treefrog $(H$. chrysoscelis) became infected. It should also be noted that transmission by arthropod vectors has not been ruled out. The frog erythrocytic virus, which appears to be an iridovirus but likely not a ranavirus (Gruia-Gray et al. 1989), was mechanically transmitted between metamorphosed bullfrogs by Culex territans mosquitos and the midge, Forcipomyia (Lasiohelea) fairfaxensis (Gruia-Gray and Desser 1992). Allender et al. (2006) speculated that ranaviruses may be transmitted between chelonians by vectors because the virus is found in circulating blood cells in turtles. Kimble et al. (2014) recently detected ranavirus in mosquitoes at a site with ranavirus-infected eastern box turtles. Mosquito transmission might help explain how ranaviruses continue to spread between turtles that rarely encounter one another and die fairly quickly from infection.

Different routes of transmission likely result in individuals being exposed to different amounts of virus, which can have dramatic effects on the probability and outcome of infection. Dose-response experiments in fish and amphibians have demonstrated that exposure to larger doses of ranavirus leads to an increased probability of infection and death with reduced survival time (Plumb and Zilberg 1999b; Pearman et al. 2004; Brunner et al. 2005; Deng et al. 2011; Warne et al. 2011). Consuming infected tissues, which likely exposes hosts to a greater dose of 
virus, is thus expected to increase the chance of infection compared with a single contact or swimming through contaminated water. Consistent with this hypothesis, Hoverman et al. (2010) found that tadpoles that were orally inoculated with FV3like viruses died faster than those exposed via water bath. Although rarely evaluated in an ecologically relevant context, there may be a minimum dose necessary to cause infection and disease (e.g., $10^{2} \mathrm{PFU} \mathrm{mL}^{-1}$ in tiger salamander larvae) and a threshold above which dose becomes unimportant (e.g., $>10^{4} \mathrm{PFU} \mathrm{mL}^{-1}$; Brunner et al. 2005). It is important to note that even within highly standardized exposures, the course and outcome of infections can vary greatly (e.g., Beck et al. 2006).

Lastly, we are aware of no published studies on ranavirus transmission rates or dynamics in wild populations. Virtually every study on transmission focuses on the routes by which ranavirus can be transmitted, ignoring the critical role that host behavior, density, and contact rates may play in shaping transmission dynamics. One problem is a lack of longitudinal data. That is, studies that track the incidence of ranavirus infection and mortality over time are rare (Gray et al. 2015). A focus on collecting the data that could be used to parameterize epidemiological models would significantly advance our understanding of ranavirus ecology (Gray et al. 2015).

\section{Ranavirus Transmission Between Species}

It is clear that ranaviruses can infect a wide range of hosts (Duffus et al. 2015), but until recently it was unclear whether these viruses were restricted to certain closely related taxa or could be transmitted between classes of ectothermic vertebrates. Anecdotal evidence from the wild suggested the possibility of interclass transmission. For example, morbid fish and turtles have been reported in association with amphibian die-offs due to ranaviral disease (Mao et al. 1999; Farnsworth and Seigel 2013). Moreover, several laboratory studies have demonstrated that BIV and FV3like viruses isolated from one vertebrate class could be used to experimentally infect animals in another (Moody and Owens 1994; Ariel and Owens 1997; Bang Jensen et al. 2009, 2011b; Gobbo et al. 2010; Bayley et al. 2013; Brenes et al. 2014b). Recently, Brenes et al. (2014a) paired ranavirus-exposed and -unexposed hosts from different vertebrate classes on opposite sides of a fine mesh screen, preventing direct contact but allowing water and virions to pass through. They demonstrated that redeared slider hatchlings and western mosquito fish (Gambusia affinis) were able to transmit an FV3-like ranavirus to Cope's gray treefrog tadpoles, resulting in $50 \%$ and $10 \%$ mortality, respectively. Treefrog tadpoles infected $30 \%$ of red-eared sliders (although no mortality occurred in the 28-day experiment), but none of the mosquito fish. While it is important to demonstrate that interclass transmission is possible, the more important question may be understanding how individuals of different classes contact (or consume) one another in ways that promote direct transmission or overlap in space and time so that indirect transmission can occur (Gray et al. 2009a). 


\section{Susceptibility to Ranaviruses Among Species}

There are a growing number of experimental studies investigating the relative susceptibility of amphibian species to ranavirus infection and disease (Cullen et al. 1995; Cullen and Owens 2002; Schock et al. 2008; Hoverman et al. 2010, 2011; Haislip et al. 2011). Until the recent studies by Brenes et al. (2014a, b), comparative studies involving reptiles were generally lacking, and those involving fish are largely restricted to EHNV (Becker et al. 2013; Langdon 1989; but see Brenes et al. 2014b). Note, however, that several recent studies have exposed different fish species to multiple ranaviruses from fish and amphibians, so collectively information is accumulating on the relative susceptibility of fish (Bang Jensen et al. 2009, 2011a; Gobbo et al. 2010; Brenes et al. 2014b).

From these studies, two patterns seem to emerge. First, species vary a great deal in susceptibility to any given ranavirus. For instance, Becker et al. (2013) challenged 12 economically and ecologically important freshwater fish in Australia with EHNV. Four were susceptible, one (the eastern mosquitofish, G. holbrooki) was a potential carrier, and seven either did not become infected or recovered from infection (Becker et al. 2013). Similarly, the outcome of exposure to an FV3-like ranavirus varied dramatically among 14 anurans and five caudates from North America, from complete mortality to no infections detected at the end of the experiment (Hoverman et al. 2010, 2011; Haislip et al. 2011). Challenges with three FV3-like ranaviruses isolated from a chelonian, fish, and anuran resulted in infection in only two of five fish species (including the western mosquitofish) and two of three highly aquatic turtles (Florida softshell turtle, Apalone ferox, and Mississippi map turtle, Graptemys pseudogeographica kohni; Brenes et al. 2014b). In addition to differences among host species, it is clear that susceptibility varies among developmental stages and environmental conditions (Sect. 3.3). So while we often speak of the susceptibility of fish or frogs to ranaviruses or treat all ranaviruses as very similar, it is increasingly clear that such broad statements mask a great deal of important variation. Explaining this variation remains a challenge.

In a promising step forward, Hoverman et al. (2011) used a comparative phylogenetic approach with 19 amphibian species from seven families to assess possible correlates (e.g., phylogenetic relatedness, life history, ecology) of susceptibility to ranavirus (FV3) infection. Certain families (Ranidae) were more susceptible on average than others (Hylidae and Ambystomatidae), but there were also patterns related to ecology and life history. Species that breed in semi-permanent wetlands and have limited distributions (i.e., rare species) were more susceptible to infection. Additionally, there was evidence that species with rapidly developing larvae were more susceptible to infection. This result could be driven by life history trade-offs such that investment in growth and development comes at the cost of defense against pathogens. Such a trade-off has been observed with trematode infections in amphibians (Johnson et al. 2012), and it is clear that ranavirus infections do impart costs in terms of growth and development (Echaubard et al. 2010). 
Given this interspecific variation in susceptibility (and, presumably, differences in shedding rates and behavior), community composition is likely to influence the likelihood, dynamics, and outcome of ranavirus outbreaks. Species that amplify pathogen transmission increase the likelihood of an outbreak occurring (Paull et al. 2012). Moreover, the order in which host species are exposed to the pathogen may change outcomes. Brenes (2013) demonstrated in aquatic mesocosms that, if wood frog tadpoles were exposed to ranavirus first, community-level mortality was greater than if upland chorus frog ( $P$. feriarum) or spotted salamander (A. maculatum) larvae were exposed first. Additionally, if the community was composed of three highly susceptible species, community-level morality was greater than if it was composed of only one highly susceptible species (Brenes 2013).

The second general pattern of susceptibility is that, despite their generally broad host ranges, ranaviruses appear to be better at infecting animals in the taxonomic class from which they were isolated. In particular, it appears that fish and at least some reptiles are less susceptible to ATV and FV3-like ranaviruses than amphibians (Jancovich et al. 2001; Picco et al. 2010; Allender et al. 2013b; Brenes et al. 2014a). Several studies have demonstrated little or no transmission of ATV (Jancovich et al. 2001; Picco et al. 2010) and FV3 to fish (Ariel et al. 2010; Gobbo et al. 2010; Bang Jensen et al. 2011a; but see Bang Jensen et al. 2011b). Similarly, amphibians may be less susceptible to fish ranaviruses. Bayley et al. (2013) found that the European common frog could be infected with FV3 and REV as tadpoles and adults (and with PPIV as tadpoles), but not with several other fish viruses (doctorfish virus, European sheetfish virus, guppy virus 6, EHNV, and SERV). Distinctions in host range may be found even within species of ranavirus. For example, the turtles in Brenes et al. (2014b) developed subclinical infections with FV3-like viruses isolated from a fish and turtle, but none were infected by the frog isolate. We caution against extrapolating these patterns too broadly, however. Researchers have only begun to sketch the host ranges of ranaviruses, so it remains an open question whether the patterns described above are general, and if so, why.

\section{Persistence of Ranaviruses in the Environment and Carriers}

There are two potential mechanisms of persistence of ranaviruses: enduring in the environment or in sublethally infected hosts (reservoirs). Historically, ranaviruses were thought to be resistant to degradation in the environment. For instance, EHNV can persist in fish tissues frozen at -20 and $-70{ }^{\circ} \mathrm{C}$ for more than 2 years and for at least 7 days at $4{ }^{\circ} \mathrm{C}$ (Langdon 1989). EHNV is also persistent for long periods in distilled water (i.e., no decrease in titer over 97 days at $15{ }^{\circ} \mathrm{C}$ ) and in tissue culture medium dried on sterile plastic Petri dishes (between 113 and 200 days at $15^{\circ} \mathrm{C}$ in the dark; Langdon 1989). Similarly, LMBV persists in frozen tissues for 155 days (Plumb and Zilberg 1999a). However, ranaviruses degrade more quickly under more ecologically realistic conditions. In one study, LMBV lost $90 \%$ of its infectivity in water in 
$24 \mathrm{~h}$ (its T-90 value), although it remained detectable in water for at least 7 days (Grizzle and Brunner 2003). Nazir et al. (2012) found that four FV3-like viruses isolated from frogs, a tortoise, and a gecko had T-90s of between 22 and 34 days in unsterile pond water at $20^{\circ} \mathrm{C}$ and up to 72 days at $4{ }^{\circ} \mathrm{C}$, which is long enough to allow for continued transmission from the environment within an epidemic, if not between years. However, their experiment isolated virus particles from the direct action of microbes, which is problematic because bacteria and other microbes might otherwise be able to consume and inactivate pathogens. To address this issue, Johnson and Brunner (2014) collected water from five ponds and either filter-sterilized it, UV-disinfected it, or left if unmanipulated then added an FV3-like ranavirus directly to the water. They found the T-90 value in filter-sterilized water was 8 days and only 1 day in the unmanipulated pond water where aquatic microbes were present. Similarly, rapid degradation of ranavirus was observed in spring water when the common zooplankton Daphnia pulex were added to virus-inoculated water. Johnson and Brunner (2014) concluded that while ranaviruses may be resistant to adverse conditions (e.g., drying, freezing), they are likely rapidly degraded in water by naturally occurring microbes and zooplankton, suggesting direct routes of transmission (i.e., contact, ingestion) may be more important than waterborne transmission. An important caveat is that all of these studies used virus grown in cell culture; ranaviruses shed in mucous, sloughed skin, etc., may be protected from microbes and the environment.

Nazir et al. (2012) also tested the persistence of ranaviruses in soil and found T-90s of 30-48 days, which raises concern over the potential for ranaviruses to be translocated in contaminated soil (Harp and Petranka 2006). Brunner et al. (2007), however, found that ATV becomes noninfectious in pond substrate that is allowed to dry. Thus, whether water bodies or their substrate remain hydrated may be critical.

Ranaviruses can persist within infected hosts, whether dead or alive. It is clear that ranaviruses can persist for long periods in frozen carcasses (e.g., Langdon 1989). In environments that freeze soon after die-offs, frozen carcasses might be an important source of ranavirus infection in the following year (Bollinger et al. 1999). Alternatively, individuals of certain species or life history stages that are carriers (i.e., remain infected and infectious for long periods without clearing or succumbing to the infection) may act as reservoirs for more susceptible species or stages (Haydon et al. 2002). In general, only a small fraction of individuals survive for weeks or months with inapparent infections (Langdon 1989; Cullen and Owens 2002; Brunner et al. 2004; Robert et al. 2007; Haislip et al. 2011; Hoverman et al. 2011; Brenes 2013; Brenes et al. 2014b). For example, of the 43 ectothermic vertebrate species challenged with FV3-like ranaviruses by Hoverman et al. (2011), Haislip et al. (2011), Brenes (2013), and Brenes et al. (2014b), there was about an $85 \%$ correlation between infection and mortality after 28 days. Still, it may take only a few subclinically infected individuals to transmit ranavirus to more susceptible individuals or species, thereby initiating outbreaks (Brunner et al. 2004). Additionally, Robert et al. (2007) demonstrated that X. laevis, which is generally resistant to FV3 infections, can be asymptomatic carriers. In a subsequent study, Morales et al. (2010) showed that peritoneal macrophages sometimes harbor quiescent FV3 infections for at least 3 weeks. Asymptomatic infections can be reactivated 
in animals that are immunocompromised by $\gamma$-irradiation (Robert et al. 2007). Whether these inapparently infected Xenopus or individuals of other species survive and retain infections over longer periods, and how they can transmit the infection to other individuals remain open questions (but see Sect. 3.2).

\section{Selection and Coevolution of Ranaviruses and Their Hosts}

Ranaviruses can be a strong selective force on their host populations, frequently causing epidemics that result in extreme population fluctuations and even localized extinctions. As an example, past selection by ranavirus infections appears to favor certain MHC Class I alleles (associated with viral recognition and antigen presentation) among European common frog populations. Particular MHC Class I alleles were found in higher frequencies among populations with a history of ranaviral disease relative to populations with no history of infection (Teacher et al. 2009). In addition, decreases in heterozygosity and relatedness were observed, suggesting epidemics led to behavioral changes in mating patterns (Teacher et al. 2009).

There is ample evidence of variation among amphibian populations in their susceptibility to ranaviruses, presumably because of underlying genetic differences. Laboratory experiments commonly reveal dramatic differences in mortality or infection rates between populations (Pearman et al. 2004; Brunner et al. 2005; Pearman and Garner 2005; Schock et al. 2008; Brunner and Collins 2009; Echaubard et al. 2014). As an example, Pearman et al. (2004) found that two populations of Italian agile frog (Rana latastei) with low genetic diversity experienced $100 \%$ mortality in just 5 days following exposure to FV3, while four other populations with higher genetic diversity experienced 40-70\% mortality. Similarly, inbred lines of the African clawed frog tadpoles had dramatically lower survival times than outbred lines (Gantress et al. 2003).

Given the large, and presumably heritable, variation in susceptibility and the strong selective pressure placed on host populations by ranaviruses, we would generally expect ranaviruses and their hosts to coevolve. This coevolutionary potential is exemplified by the tiger salamander-ATV system because tiger salamanders are commonly found in the absence of other amphibians and epidemics are common (Brunner et al. 2004). Three lines of evidence suggest coevolution in this system. First, there is a negative correlation between disease frequency and cannibal frequency among salamander populations throughout Arizona (Pfennig et al. 1991). Although cannibals enjoy a performance advantage by preying on conspecifics (Reilly et al. 1992), cannibalism comes at the cost of increased risk of acquiring ATV (and other pathogens) from conspecifics, such that reduced cannibalism might prevent disease spread (Pfennig et al. 1991; Bolker et al. 2008). Common garden experiments suggest these patterns are genetically based and thus likely result from past selection (Parris et al. 2005). Animals were not plastic in development of the cannibalistic phenotype between treatments with and without ATV, and observed differences in the frequency of cannibals in the field were replicated in the lab (Parris et al. 2005). 
Second, the tight coupling of viral persistence and the life cycle of the host suggests a coevolutionary history. Larvae, branchiate adults, and metamorphosed adults are all susceptible to ATV, but larvae are significantly more likely to recover than metamorphs (Brunner et al. 2004). Ranavirus epidemics occur in ponds in the larval stage, but many metamorphs leave ponds with sublethal infections, overwinter, and return in later years to breed (Brunner et al. 2004). Salamanders themselves are thus a critical reservoir for ATV, serving as a key source of virus transmission among or within populations across years.

Third, molecular genetic analyses of phylogenetic concordance suggest coevolution between salamander populations and local ATV strains (Storfer et al. 2007). Excluding the three host switches attributed to the movement of infected salamanders as fishing bait (Jancovich et al. 2005), there is complete concordance between phylogenetic trees for both salamanders and virus (Storfer et al. 2007). In addition, nodal depths, or the timing of putative speciation or divergence events, were strongly correlated in ATV strains and their associated tiger salamander populations (Storfer et al. 2007). Moreover, there appears to be local selection for molecular evolution of different ATV strains in different tiger salamander populations. ATV genes associated with host immune evasion (Jancovich and Jacobs 2011) have evolved unique amino acid differences among spatially distinct tiger salamander populations independently of their phylogenetic relationships (Ridenhour and Storfer 2008). Taken together, these findings provide strong support for a coevolutionary history of ATV and its tiger salamander host.

\section{The Evolution of Virulence in Ranaviruses}

Although ranaviruses are often recognized for their high virulence, there is wide variation in virulence among viral strains and host species. For example, Brunner and Collins (2009) challenged tiger salamander larvae with nine strains of ATV and found that virulence (measured as the time to death) varied substantially among isolates and was apparently heritable. This and similar results from many other studies that consider virulence raise the question: why are some viruses or strains more virulent than others?

One widespread and important hypothesis for variation in virulence posits a trade-off between transmission and virulence, the latter of which is generally seen as an unavoidable by-product of replicating in and being transmitted from the host (Lenski and May 1994; Alizon et al. 2009). Highly virulent pathogens may have fewer opportunities for transmission than less virulent strains because they rapidly kill their hosts, leading to the widespread assumption that parasites evolve to intermediate virulence levels. However the optimal level of virulence, and even the existence of a trade-off, depends heavily on the ecology of the host (e.g., density, background mortality), pathogen (e.g., competition between pathogens within a host, host immune responses), and their interaction (e.g., transmission mode, cause of pathogenesis; Day 2001; Day 2002; Day and Proulx 2004; Ebert 1999). 
Conditions that favor rapid transmission (e.g., dense host populations, an influx of naïve hosts), reduce the infectious period (e.g., high background mortality rates, rapid clearance by the immune system), or lead to competition among strains within hosts (i.e., multiple infections) generally favor more virulent pathogens (May and Nowak 1994; Ebert and Mangin 1997; Williams and Day 2001; Cooper et al. 2002; Gandon et al. 2002; Day 2003; Restif and Koella 2003; Alizon and van Baalen 2008). Hosts that tolerate infections (i.e., minimize the fitness consequences) rather than resist or clear infections are expected to circumvent the evolution of increased host virulence (Roy and Kirchner 2000; Restif and Koella 2003). The details of the host-pathogen system, however, often drive the expected evolutionary dynamics (Day 2001, 2002; Sabelis and Metz 2002; Day and Proulx 2004), so we must be careful in applying virulence theory to ranavirus-host systems.

One pattern that is becoming clear, however, is that ranaviruses isolated from captive settings (e.g., aquaculture and ranaculture facilities, bait shops) are more virulent relative to wild strains. For instance, an ATV strain isolated from a fishing bait store was significantly more virulent (i.e., caused greater mortality) to tiger salamander larvae than native strains (Storfer et al. 2007). Similarly, an FV3 strain isolated from a bullfrog farm in Idaho (RCV-Z; Majji et al. 2006) grew significantly faster in vivo and caused significantly higher mortality in bullfrog and spotted frog (Lithobates luteiventris) tadpoles than a strain isolated from a wild bullfrog population in Washington (AS, KC, Washington State University, unpublished data). Hoverman et al. (2011) also found that an FV3-like ranavirus from a captive bullfrog facility was more virulent, causing an average of $51 \%$ more mortality in laboratory experiments across eight species of larval anurans, compared to the type isolate of FV3. An FV3-like ranavirus isolated from a pallid sturgeon hatchery has proven to be among the most virulent strains identified to date (Waltzek et al. 2014).

There are several hypotheses that might explain the evolution of increased virulence of ranaviruses in captive settings. First, the cost of virulence-host death before transmission has occurred-may be reduced in captive settings because of high rates of background mortality or because conditions promote rapid transmission. High stocking densities are likely to increase contact rates and the buildup of shed virions, both of which will increase transmission rates. Also, the death of the host is not the end of the infectious period for ranaviruses. Depending on the facility, infectious carcasses may not be removed before susceptible individuals scavenge them and become infected, whereas in nature other scavengers and organisms that facilitate decomposition are likely to be more abundant, and thus these carcasses disappear more quickly. Second, selection during the initial phases of a growing epidemic, when susceptible hosts are not limiting, should favor rapid transmission and virulence (Day and Proulx 2004; Bolker et al. 2010). If new, susceptible animals are continually introduced into a population undergoing an epidemic, as appears to be the case in some bait shops selling tiger salamanders (Picco and Collins 2008), this could favor more proliferative, virulent viral strains over those that would be favored when hosts become limiting. Lastly, competition between pathogens within a host can favor increased virulence, even at the cost of reduced transmission (e.g., de Roode et al. 2005). Captive settings, which often receive animals from many 
sources (e.g., Woodland et al. 2002b), may harbor several co-circulating ranavirus strains, with the effect of selecting the most virulent strains (Antia et al. 1994; Bull 1994). While all of these hypotheses remain to be tested, collectively their logic suggests a need to change the conditions and practices in captive facilities that may promote ranavirus transmission, mixing, and persistence.

These results also raise concern that introduction of infected bait tiger salamanders or American bullfrogs may introduce novel, highly virulent viral strains into areas with naïve hosts or into areas where hosts have been previously exposed but are adapted to other ranavirus strains. Bullfrogs in particular comprise a major portion of amphibians involved in international trade. Schloegel et al. (2009) reported that over 28 million amphibians were imported into the USA during 2000-2005, with an $8.5 \%$ prevalence of ranavirus infection. Farmed and wild bullfrogs and other amphibians are traded globally in enormous quantities (Altherr et al. 2011), making international trade an important route for the translocation and introduction of ranaviruses (Fig. 2, Schloegel et al. 2010). A key question is thus whether introduced, virulent ranavirus strains persist or outcompete resident strains of ranavirus in the wild.

\section{The Risk of Extinction from Ranaviruses}

De Castro and Bolker (2005) reviewed three theoretical mechanisms by which pathogens could cause the extinction of their host. First, small, isolated populations may be at risk of stochastic extinction from disease. Highly transmissible, virulent pathogens, such as ranaviruses, can also reduce initially dense populations to levels where demographic fluctuations or related genetic effects (e.g., inbreeding) can lead to stochastic extinction. Second, pathogens transmitted in a density-independent fashion are capable of continued transmission as host densities decline, even to the point of host extinction. One common example of density-independent transmission is sexually transmitted infections, but any form of aggregation (e.g., localized feeding or breeding sites) can maintain high rates of transmission, regardless of host density. Even brief periods of density-independent transmission (e.g., during breeding) can lead to pathogen-driven extinction (Ryder et al. 2007). Third, pathogens that have biotic (other species) or abiotic (environmental) reservoirs will also continue to infect hosts irrespective of host densities, and so have the potential to cause host extinction.

Ranaviruses appear to meet the conditions required to cause host extinction by any or all of these mechanisms (Miller et al. 2011). Given the broad host range and frequent movement of ranaviruses in regional and international trade, it is easy to imagine how a highly virulent and transmissible ranavirus might be introduced into small or naïve populations. Second, while a laboratory experiment with ATV in tiger salamander larvae found that the rate of transmission increased with the density of infected larvae, it quickly saturated and led to substantial rates of infection even at the lowest density (Greer et al. 2008). Moreover, there are many examples of ectothermic vertebrates aggregating as they feed, shelter, and mate, which could 
lead to at least short-term density-independent transmission. Lastly, as noted above, ranaviruses may persist in the environment long enough to be transmitted to naïve hosts. Perhaps more importantly, fish, amphibians and reptiles often overlap with other, less susceptible or more abundant species that act as biotic reservoirs for the species of interest. Collectively, there is good reason to think that ranaviruses can lead to host extinction (Miller et al. 2011).

In spite of this potential for ranaviruses to cause host extinctions, it is difficult to find specific examples of ranavirus leading to regional or global extinctions or, until recently, declines. Few long-term datasets exist that have followed wild populations of ectothermic vertebrates with reoccurring die-offs from ranavirus, and at least for amphibians, long datasets are often required to be certain of declines (Alford and Richards 1999). To some degree this may be explained by the fact that ranaviruses often affect the larval or juvenile stages (see Sects. 2.1 and 3.3) and for many taxa these stages can be less important demographically than adults (Biek et al. 2002). We would thus expect populations or species where the adults were most affected by ranaviruses to display the greatest declines (but see Earl and Gray 2014). Indeed, Teacher et al. (2010) reported an $81 \%$ median reduction in population abundance of common frog (Rana temporaria) adults at ponds in the UK with known reoccurring die-offs from ranaviral disease. Again, ranaviruses in the UK appear to primarily affect adults (Cunningham et al. 1993; Teacher et al. 2010; Duffus et al. 2013). Similarly, the significant ranavirus mortality observed in adult turtles presumably puts these populations at increased risk of extinction as well (Belzer and Seibert 2011; Farnsworth and Seigel 2013).

Repeated ranavirus epidemics in larval amphibians may also lead to declines and local extinctions. Petranka et al. (2003, 2007), for instance, reported minimal recruitment of wood frogs at several newly constructed wetlands over an 8-year period due to annual die-offs from ranaviral disease. Recently, Earl and Gray (2014) used a matrix population-projection model to demonstrate that local extirpation of a closed wood frog population was likely if larvae or metamorphs were exposed to ranavirus once every 5 years. For populations that were exposed every year, time to extinction could be as rapid as 5 years (Earl and Gray 2014). Moreover, a sensitivity analysis showed that survival of the pre-metamorphic stages was more important than post-metamorphic stages for the wood frog, providing initial evidence that significant mortality of larvae due to ranavirus could lead to population extinction (Earl and Gray 2014). Susceptible species in fragmented landscapes with limited dispersal may be at greater risk of extinction than has been previously recognized (Collins and Crump 2009).

The most compelling example of recurring ranavirus epidemics leading to amphibian declines comes from the Picos de Europa National park in Spain (Price et al. 2014). These communities were monitored for six years, during which ranaviruses were apparently introduced, leading to significant declines over the following years. What makes these virus-host community interactions different from others that have not suffered declines remains unknown. Clearly, there is a need for more studies of the population-level effects of ranavirus outbreaks, particularly long-term studies of sites with reoccurring ranavirus die-offs (Gray et al. 2015). 
Additionally, it will be important to incorporate host and virus dispersal (e.g., metapopulation dynamics) into mathematical models and studies to understand the risk that ranaviruses pose to their ectothermic vertebrate hosts.

Acknowledgments We thank the members of the Brunner lab for comments on early drafts, Jake Kerby and David Lesbarrères for their careful reviews and helpful suggestions, and the editors, without whose enormous efforts this chapter and book would not exist. AS would like to acknowledge funding from NSF grant DEB 1316549.

Open Access publication was made possible through grants provided by the University of Tennessee (Institute of Agriculture, Office of Research and Engagement, and Department of Forestry, Wildlife and Fisheries), Washington State University Libraries, Gordon State College (Office of Academic Affairs), the Association of Reptilian and Amphibian Veterinarians, and the Amphibian and Reptile Conservancy.

Open Access This chapter is distributed under the terms of the Creative Commons Attribution Noncommercial License, which permits any noncommercial use, distribution, and reproduction in any medium, provided the original author(s) and source are credited.

\section{References}

Ahne W, Bremont M, Hedrick RP, Hyatt AD, Whittington RJ (1997) Special topic review: iridoviruses associated with epizootic haematopoietic necrosis (EHN) in aquaculture. World $\mathbf{J}$ Microbiol Biotechnol 13:367-373

Alford RA, Richards SJ (1999) Global amphibian declines: a problem in applied ecology. Annu Rev Ecol Syst 30:133-165

Alizon S, van Baalen M (2008) Multiple infections, immune dynamics, and the evolution of virulence. Am Nat 172:E150-E168

Alizon S, Hurford A, Mideo N, Van Baalen M (2009) Virulence evolution and the trade-off hypothesis: history, current state of affairs and the future. J Evol Biol 22:245-259

Allender MC, Fry MM, Irizarry AR, Craig L, Johnson AJ, Jones M (2006) Intracytoplasmic inclusions in circulating leukocytes from an eastern box turtle (Terrapene carolina carolina) with iridoviral infection. J Wildl Dis 42:677-684

Allender MC, Mitchell MA, McRuer D, Christian S, Byrd J (2013a) Prevalence, clinical signs, and natural history characteristics of frog virus 3-like infections in eastern box turtles (Terrapene carolina carolina). Herpetol Conserv Biol 8:308-320

Allender MC, Mitchell MA, Torres T, Sekowska J, Driskell EA (2013b) Pathogenicity of frog virus 3-like virus in red-eared slider turtles (Trachemys scripta elegans) at two environmental temperatures. J Comp Pathol 149:356-367

Altherr S, Goyenechea A, Schubert DJ (2011) Canapés to extinction: the international trade in frogs' legs and its ecological impact. A report by Pro Wildlife, Defenders of Wildlife and Animal Welfare Institute, Washington, DC

Altig R, Whiles MR, Taylor CL (2007) What do tadpoles really eat? Assessing the trophic status of an understudied and imperiled group of consumers in freshwater habitats. Freshw Biol 52:386-395

Altizer S, Ostfeld RS, Johnson PT, Kutz S, Harvell CD (2013) Climate change and infectious diseases: from evidence to a predictive framework. Science 341:514-519

Antia R, Levin BR, May RM (1994) Within-host population dynamics and the evolution and maintenance of microparasite virulence. Am Nat 144:457-472

Ariel E (1997) Pathology and serological aspects of Bohle iridovirus infections in six selected water-associated reptiles in North Queensland. Dissertation, James Cook University, North Queensland 
Ariel E (2011) Viruses in reptiles. Vet Res 42:12

Ariel E, Jensen BB (2009) Challenge studies of European stocks of redfin perch, Perca fluviatilis L., and rainbow trout, Oncorhynchus mykiss (Walbaum), with epizootic haematopoietic necrosis virus. J Fish Dis 32:1017-1025

Ariel E, Owens L (1997) Epizootic mortalities in tilapia Oreochromis mossambicus. Dis Aquat Organ 29:1-6

Ariel E, Kielgast J, Svart HE, Larsen K, Tapiovaara H, Bang JB, Holopainen R (2009a) Ranavirus in wild edible frogs Pelophylax kl. esculentus in Denmark. Dis Aquat Organ 85:7-14

Ariel E, Nicolajsen N, Christophersen MB, Holopainen R, Tapiovaara H, Jensen BB (2009b) Propagation and isolation of ranaviruses in cell culture. Aquaculture 294:159-164

Ariel E, Holopainen R, Olesen NJ, Tapiovaara H (2010) Comparative study of ranavirus isolates from cod (Gadus morhua) and turbot (Psetta maxima) with reference to other ranaviruses. Arch Virol 155:1261-1271

Bang Jensen B, Ersboll AK, Ariel E (2009) Susceptibility of pike Esox lucius to a panel of Ranavirus isolates. Dis Aquat Organ 83:169-179

Bang Jensen B, Reschova S, Cinkova K, Ariel E, Vesely T (2011a) Common carp (Cyprinus carpio) and goldfish (Carassius auratus) were not susceptible to challenge with ranavirus under certain challenge conditions. Bull Eur Assoc Fish Pathol 31:112-118

Bang Jensen B, Holopainen R, Tapiovaara H, Ariel E (2011b) Susceptibility of pike-perch Sander lucioperca to a panel of ranavirus isolates. Aquaculture 313:24-30

Bayley AE, Hill BJ, Feist SW (2013) Susceptibility of the European common frog Rana temporaria to a panel of ranavirus isolates from fish and amphibian hosts. Dis Aquat Organ 103:171-183

Beck BH, Bakal RS, Brunner CJ, Grizzle JM (2006) Virus distribution and signs of disease after immersion exposure to largemouth bass virus. J Aquat Anim Health 18:176-183

Becker JA, Tweedie A, Gilligan D, Asmus M, Whittington RJ (2013) Experimental infection of Australian freshwater fish with epizootic haematopoietic necrosis virus (EHNV). J Aquat Anim Health 25:66-76

Belzer W, Seibert S (2011) A natural history of Ranavirus in an eastern box turtle population. Turtle Tortoise Newsl 15:18-25

Biek R, Funk WC, Maxell BA, Mills LS (2002) What is missing in amphibian decline research: insights from ecological sensitivity analysis. Conserv Biol 16:728-734

Blaustein AR, Gervasi SS, Johnson PT, Hoverman JT, Belden LK, Bradley PW, Xie GY (2012) Ecophysiology meets conservation: understanding the role of disease in amphibian population declines. Philos Trans R Soc Lond B Biol Sci 367:1688-1707

Bolker BM, de Castro F, Storfer A, Mech S, Harvey E, Collins JP (2008) Disease as a selective force precluding widespread cannibalism: a case study of an iridovirus of tiger salamanders, Ambystoma tigrinum. Evol Ecol Res 10:105-128

Bolker BM, Nanda A, Shah D (2010) Transient virulence of emerging pathogens. J R Soc Interface 7:811-822

Bollinger TK, Mao J, Schock D, Brigham RM, Chinchar VG (1999) Pathology, isolation, and preliminary molecular characterization of a novel iridovirus from tiger salamanders in Saskatchewan. J Wildl Dis 35:413-429

Brenes R (2013) Mechanisms contributing to the emergence of ranavirus in ectothermic vertebrate communities. Dissertation, University of Tennessee, Knoxville

Brenes R, Gray MJ, Waltzek TB, Wilkes RP, Miller DL (2014a) Transmission of ranavirus between ectothermic vertebrate hosts. PLoS One 9:e92476

Brenes R, Miller DL, Waltzek TB, Wilkes RP, Tucker JL, Chaney JC, Hardman RH, Brand MD, Huether RR, Gray MJ (2014b) Susceptibility of fish and turtles to three ranaviruses isolated from different ectothermic vertebrate classes. J Aquat Anim Health 26:118-126

Brunner JL, Collins JP (2009) Testing assumptions of the trade-off theory of the evolution of parasite virulence. Evol Ecol Res 11:1169-1188

Brunner JL, Schock DM, Collins JP, Davidson EW (2004) The role of an intraspecific reservoir in the persistence of a lethal ranavirus. Ecology 85:560-566 
Brunner JL, Richards K, Collins JP (2005) Dose and host characteristics influence virulence of ranavirus infections. Oecologia 144:399-406

Brunner JL, Schock DM, Collins JP (2007) Transmission dynamics of the amphibian ranavirus Ambystoma tigrinum virus. Dis Aquat Organ 77:87-95

Brunner JL, Barnett KE, Gosier CJ, McNulty SA, Rubbo MJ, Kolozsvary MB (2011) Ranavirus infection in die-offs of vernal pool amphibians in New York, USA. Herpetol Rev 42:76-79

Bull JJ (1994) Perspective: virulence. Evolution 48:1423-1437

Carey C, Cohen N, Rollins-Smith L (1999) Amphibian declines: an immunological perspective. Dev Comp Immunol 23:459-472

Chinchar VG (2002) Ranaviruses (family Iridoviridae): emerging cold-blooded killers. Arch Virol $147: 447-470$

Chinchar VG, Waltzek TB (2014) Ranaviruses: not just for frogs. PLoS Pathog 10:e1003850

Chinchar VG, Wang J, Murti G, Carey C, Rollins-Smith L (2001) Inactivation of frog virus 3 and channel catfish virus by esculentin-2P and ranatuerin-2P, two antimicrobial peptides isolated from frog skin. Virology 288:351-357

Chinchar VG, Bryan L, Silphadaung U, Noga E, Wade D, Rollins-Smith L (2004) Inactivation of viruses infecting ectothermic animals by amphibian and piscine antimicrobial peptides. Virology 323:268-275

Chinchar VG, Hyatt AD, Miyazaki T, Williams T (2009) Family Iridoviridae: poor viral relations no longer. In: Van Etten JL (ed) Current topics in microbiology and immunology, vol 328, Lesser known large dsDNA viruses. Springer, Berlin

Chua FHC, Ng ML, Ng KL, Loo JJ, Wee JY (1994) Investigation of outbreaks of a novel disease, 'Sleepy Grouper Disease', affecting the brown-spotted grouper, Epinephelus tauvina Forska. J Fish Dis 17:417-427

Collins JP, Crump ML (2009) Extinction in our times: global amphibian decline. Oxford University Press, Oxford

Cooper VS, Reiskind MH, Miller JA, Shelton KA, Walther BA, Elkinton JS, Ewald PW (2002) Timing of transmission and the evolution of virulence of an insect virus. Proc R Soc Lond B Biol Sci 269:1161-1165

Crump ML (1983) Opportunistic cannibalism by amphibian larvae in temporary aquatic environments. Am Nat 121:281-289

Cullen BR, Owens L (2002) Experimental challenge and clinical cases of Bohle iridovirus (BIV) in native Australian anurans. Dis Aquat Organ 49:83-92

Cullen CR, Owens L, Whittington RJ (1995) Experimental infection of Australian anurans (Limnodynastes terraereginae and Litoria latopalmata) with Bohle iridovirus. Dis Aquat Organ 23:83-92

Cunningham AA, Langton TES, Bennet PM, Drury SES, Gough RE, Kirkwood JK (1993) Unusual mortality associated with poxvirus-like particles in frogs (Rana temporaria). Vet Rec 133:141-142

Cunningham AA, Hyatt AD, Russell P, Bennett PM (2007a) Emerging epidemic diseases of frogs in Britain are dependent on the source of ranavirus agent and the route of exposure. Epidemiol Infect 135:1200-1212

Cunningham AA, Hyatt AD, Russell P, Bennett PM (2007b) Experimental transmission of a ranavirus disease of common toads (Bufo bufo) to common frogs (Rana temporaria). Epidemiol Infect 135:1213-1216

Daszak P, Cunningham AA, Hyatt AD (2001) Anthropogenic environmental change and the emergence of infectious diseases in wildlife. Acta Trop 78:103-116

Davidson C, Shaffer HB, Jennings MR (2002) Spatial tests of the pesticide drift, habitat destruction, UV-B, and climate-change hypotheses for California amphibian declines. Conserv Biol $16: 1588-1601$

Day $\mathrm{T}$ (2001) Parasite transmission modes and the evolution of virulence. Evolution $55: 2389-2400$

Day T (2002) Virulence evolution via host exploitation and toxin production in spore-producing pathogens. Ecol Lett 5:471-476 
Day T (2003) Virulence evolution and the timing of disease life-history events. Trends Ecol Evol 18:113-118

Day T, Proulx SR (2004) A general theory for the evolutionary dynamics of virulence. Am Nat 163:E40-E63

de Castro F, Bolker B (2005) Mechanisms of disease-induced extinction. Ecol Lett 8:117-126

de Roode JC, Pansini R, Cheesman SJ, Helinski MEH, Huijben S, Wargo AR, Bell AS, Chan BHK, Walliker D, Read AF (2005) Virulence and competitive ability in genetically diverse malaria infections. Proc Natl Acad Sci U S A 102:7624-7628

DeBenedictis PA (1974) Interspecific competition between tadpoles of Rana pipiens and Rana sylvatica: an experimental field study. Ecol Monogr 44:129-151

Deng GC, Li SJ, Xie J, Bai JJ, Chen KC, Ma DM, Jiang XY, Lao HH, Yu LY (2011) Characterization of a ranavirus isolated from cultured largemouth bass (Micropterus salmoides) in China. Aquaculture 312:198-204

Dhabhar FS (2009) Enhancing versus suppressive effects of stress on immune function: implications for immunoprotection and immunopathology. Neuroimmunomodulation 16:300-317

Duffus ALJ, Pauli BD, Wozney K, Brunetti CR, Berrill M (2008) Frog virus 3-like infections in aquatic amphibian communities. J Wildl Dis 44:109-120

Duffus ALJ, Nichols RA, Garner TWJ (2013) Investigations into the life history stages of the common frog (Rana temporaria) affected by an amphibian ranavirus in the United Kingdom. Herpetol Rev 44:260-263

Duffus ALJ, Marschang RE, Waltzek TB, Stöhr A, Allender MC, Gotesman M, Whittington R, Hick P, Hines M (2015) Distribution and host range of ranaviruses. In: Gray MJ, Chinchar VG (eds) Ranaviruses: lethal pathogens of ectothermic vertebrates. Springer, Secaucus

Earl JE, Gray MJ (2014) Introduction of ranavirus to isolated wood frog populations could cause local extinction. Ecohealth. doi:10.1007/s10393-014-0950-y

Eaton JG, Scheller RM (1996) Effects of climate warming on fish thermal habitat in streams of the United States. Limnol Oceanogr 41:1109-1115

Ebert D (1999) The evolution and expression of parasite virulence. In: Stearns SC (ed) Evolution in health and disease. Oxford University Press, New York

Ebert D, Mangin KL (1997) The influence of host demography on the evolution of virulence of a microsporidian gut parasite. Evolution 51:1828-1837

Echaubard P, Little K, Pauli B, Lesbarrères D (2010) Context-dependent effects of ranaviral infection on Northern leopard frog life history traits. PLoS One 5:e13723

Echaubard P, Leduc J, Pauli B, Chinchar VG, Robert J, Lesbarrères D (2014) Environmental dependency of amphibian-ranavirus genotypic interactions: evolutionary perspectives on infectious diseases. Evol Appl 7:723-733

Farnsworth S, Seigel R (2013) Responses, movements, and survival of relocated box turtles during construction of the intercounty connector highway in Maryland. Transp Res Rec 2362:1-8

Forson D, Storfer A (2006a) Effects of atrazine and iridovirus infection on survival and life history characteristics in long-toed salamanders, Ambystoma macrodactylum. Environ Toxicol Chem 25:168-173

Forson DD, Storfer A (2006b) Atrazine increases ranavirus susceptibility in the tiger salamander, Ambystoma tigrinum. Ecol Appl 16:2325-2332

Fox S, Greer AL, Torres-Cervantes R, Collins JP (2006) First case of ranavirus-associated morbidity and mortality in natural populations of the South American frog Atelognathus patagonicus. Dis Aquat Organ 72:87-92

Fraker ME, Hu F, Cuddapah V, McCollum SA, Relyea RA, Hempel J, Denver RJ (2009) Characterization of an alarm pheromone secreted by amphibian tadpoles that induces behavioral inhibition and suppression of the neuroendocrine stress axis. Horm Behav 55:520-529

Gahl MK, Calhoun AJK (2008) Landscape setting and risk of ranavirus mortality events. Biol Conserv 141:2679-2689

Gahl MK, Calhoun AJK (2010) The role of multiple stressors in ranavirus-caused amphibian mortalities in Acadia national park wetlands. Can J Zool 88:108-121 
Gandon S, van Baalen M, Jansen VAA (2002) The evolution of parasite virulence, superinfection, and host resistance. Am Nat 159:658-669

Gantress J, Maniero GD, Cohen N, Robert J (2003) Development and characterization of a model system to study amphibian immune responses to iridoviruses. Virology 311:254-262

Gobbo F, Cappellozza E, Pastore MR, Bovo G (2010) Susceptibility of black bullhead Ameiurus melas to a panel of ranavirus isolates. Dis Aquat Organ 90:167-174

Goldberg TL (2002) Largemouth bass virus: an emerging problem for warmwater fisheries? In: Philipp DP, Ridgway MS (eds) American Fisheries Society symposium 31, Bethesda

Goodman RM, Miller DL, Ararso YT (2013) Prevalence of ranavirus in Virginia turtles as detected by tail-clip sampling versus oral-cloacal swabbing. Northeast Nat 20:325-332

Gosner KL (1960) A simplified table for staging anuran embryos and larvae with notes on identification. Herpetologica 16:183-190

Granoff A, Came PE, Breeze DC (1966) Viruses and renal carcinoma of Rana pipiens I. The isolation and properties of virus from normal and tumor tissue. Virology 29:133-148

Grant EC, Philipp DP, Inendino KR, Goldberg TL (2003) Effects of temperature on the susceptibility of largemouth bass to largemouth bass virus. J Aquat Anim Health 15:215-220

Grant EC, Inendino KR, Love WJ, Philipp DP, Goldberg TL (2005) Effects of practices related to catch-and-release angling on mortality and viral transmission in juvenile largemouth bass infected with largemouth bass virus. J Aquat Anim Health 17:315-322

Gray MJ, Miller DL, Schmutzer AC, Baldwin CA (2007) Frog virus 3 prevalence in tadpole populations inhabiting cattle-access and non-access wetlands in Tennessee, USA. Dis Aquat Organ 77:97-103

Gray MJ, Miller DL, Hoverman JT (2009a) Ecology and pathology of amphibian ranaviruses. Dis Aquat Organ 87:243-266

Gray MJ, Miller DL, Hoverman JT (2009b) First report of ranavirus infecting lungless salamanders. Herpetol Rev 40:316-319

Gray MJ, Brunner JL, Earl JE, Ariel E (2015) Design and analysis of ranavirus studies: surveillance and assessing risk. In: Gray MJ, Chinchar VG (eds) Ranaviruses: lethal pathogens of ectothermic vertebrates. Springer, Secaucus

Green DE, Converse KA (2005) Diseases of frogs and toads. In: Majumdar SK, Huffman JE, Brenner FJ, Panah AI (eds) Wildlife diseases: landscape epidemiology, spatial distribution and utilization of remote sensing technology. Easton, Pennsylvania

Green DE, Converse KA, Schrader AK (2002) Epizootiology of sixty-four amphibian morbidity and mortality events in the USA, 1996-2001. Ann N Y Acad Sci 969:323-339

Greer AL, Collins JP (2008) Habitat fragmentation as a result of biotic and abiotic factors controls pathogen transmission throughout a host population. J Anim Ecol 77:364-369

Greer AL, Berrill M, Wilson PJ (2005) Five amphibian mortality events associated with ranavirus infection in south central Ontario, Canada. Dis Aquat Organ 67:9-14

Greer AL, Briggs CJ, Collins JP (2008) Testing a key assumption of host-pathogen theory: density and disease transmission. Oikos 117:1667-1673

Greer AL, Brunner JL, Collins JP (2009) Spatial and temporal patterns of Ambystoma tigrinum virus (ATV) prevalence in tiger salamanders (Ambystoma tigrinum nebulosum). Dis Aquat Organ 85:1-6

Grizzle JM, Brunner CJ (2003) Review of largemouth bass virus. Fisheries 28:10-14

Grizzle JM, Altinok I, Fraser WA, Francis-Floyd R (2002) First isolation of largemouth bass virus. Dis Aquat Organ 50:233-235

Groocock GH, Grimmett SG, Getchell RG, Wooster GA, Bowser PR (2008) A survey to determine the presence and distribution of largemouth bass virus in wild freshwater bass in New York State. J Aquat Anim Health 20:158-164

Gruia-Gray J, Desser SS (1992) Cytopathological observations and epizootiology of frog erythrocytic virus in bullfrogs (Rana catasbeiana). J Wildl Dis 28:34-41

Gruia-Gray J, Petric M, Desser S (1989) Ultrastructural, biochemical, and biophysical properties of an erythrocytic virus of frogs from Ontario, Canada. J Wildl Dis 25:497-506 
Haddad JJ, Saadé NE, Safieh-Garabedian B (2002) Cytokines and neuro-immune-endocrine interactions: a role for the hypothalamic-pituitary-adrenal revolving axis. J Neuroimmunol 133:1-19

Haislip NA, Gray MJ, Hoverman JT, Miller DL (2011) Development and disease: how susceptibility to an emerging pathogen changes through anuran development. PLoS One 6:e22307

Haislip NA, Hoverman JT, Miller DL, Gray MJ (2012) Natural stressors and disease risk: does the threat of predation increase amphibian susceptibility to ranavirus? Can J Zool 90:893-902

Hanson LA, Petrie-Hanson L, Meals KO, Chinchar VG, Rudis M (2001) Persistence of largemouth bass virus infection in a northern Mississippi reservoir after a die-off. J Aquat Anim Health 13:27-34

Harikrishnan R, Balasundaram C, Heo M-S (2010) Molecular studies, disease status and prophylactic measures in grouper aquaculture: economic importance, diseases and immunology. Aquaculture 309:1-14

Harp EM, Petranka JW (2006) Ranavirus in wood frogs (Rana sylvatica): potential sources of transmission within and between ponds. J Wildl Dis 42:307-318

Haydon DT, Cleaveland S, Taylor LH, Laurenson MK (2002) Identifying reservoirs of infection: a conceptual and practical challenge. Emerg Infect Dis 8:1468-1473

Homan RN, Bartling JR, Stenger RJ, Brunner JL (2013) Detection of Ranavirus in Ohio, USA. Herpetol Rev 44:615-618

Hoverman JT, Gray MJ, Miller DL (2010) Anuran susceptibilities to ranaviruses: role of species identity, exposure route, and a novel virus isolate. Dis Aquat Organ 89:97-107

Hoverman JT, Gray MJ, Haislip NA, Miller DL (2011) Phylogeny, life history, and ecology contribute to differences in amphibian susceptibility to ranaviruses. Ecohealth 8:301-319

Hoverman JT, Gray MJ, Miller DL, Haislip NA (2012) Widespread occurrence of ranavirus in pond-breeding amphibian populations. Ecohealth 9:36-48

Huang SM, Tu C, Tseng CH, Huang CC, Chou CC, Kuo HC, Chang SK (2011) Genetic analysis of fish iridoviruses isolated in Taiwan during 2001-2009. National Taiwan University, Graduate Institute of Veterinary Medicine, Taipei

Jancovich JK, Jacobs BL (2011) Innate immune evasion mediated by the Ambystoma tigrinum virus eukaryotic translation initiation factor $2 \alpha$ homologue. J Virol 85:5061-5069

Jancovich JK, Davidson EW, Morado JF, Jacobs BL, Collins JP (1997) Isolation of a lethal virus from the endangered tiger salamander Ambystoma tigrinum stebbinsi. Dis Aquat Organ 31:161-167

Jancovich JK, Davidson EW, Seiler A, Jacobs BL, Collins JP (2001) Transmission of the Ambystoma tigrinum virus to alternative hosts. Dis Aquat Organ 46:159-163

Jancovich J, Davidson EW, Parameswaran N, Mao J, Chinchar VG, Collins JP, Jacobs BL, Storfer A (2005) Evidence for emergence of an amphibian iridoviral disease because of humanenhanced spread. Mol Ecol 14:213-224

Johnson AF, Brunner JL (2014) Persistence of an amphibian ranavirus in aquatic communities. Dis Aquat Organ 111:129-138

Johnson AJ, Pessier AP, Jacobson ER (2007) Experimental transmission and induction of ranaviral disease in western ornate box turtles (Terrapene ornata ornata) and red-eared sliders (Trachemys scripta elegans). Vet Pathol 44:285-297

Johnson AJ, Pessier AP, Wellehan JFX, Childress A, Norton TM, Stedman NL, Bloom DC, Belzer W, Titus VR, Wagner R, Brooks JW, Spratt J, Jacobson ER (2008) Ranavirus infection of freeranging and captive box turtles and tortoises in the United States. J Wildl Dis 44:851-863

Johnson AJ, Wendland L, Norton TM, Belzer B, Jacobson ER (2010) Development and use of an indirect enzyme-linked immunosorbent assay for detection of iridovirus exposure in gopher tortoises (Gopherus polyphemus) and eastern box turtles (Terrapene carolina carolina). Vet Microbiol 142:160-167

Johnson PT, Rohr JR, Hoverman JT, Kellermanns E, Bowerman J, Lunde KB (2012) Living fast and dying of infection: host life history drives interspecific variation in infection and disease risk. Ecol Lett 15:235-242

Keeling MJ, Rohani P (2008) Modeling infectious diseases in humans and animals. Princeton University Press, Princeton 
Kerby JL, Storfer A (2009) Combined effects of atrazine and chlorpyrifos on susceptibility of the tiger salamander to Ambystoma tigrinum virus. Ecohealth 6:91-98

Kerby JL, Hart AJ, Storfer A (2011) Combined effects of virus, pesticide, and predator cue on the larval tiger salamander (Ambystoma tigrinum). Ecohealth 8:46-54

Kik M, Martel A, Sluijs AS, Pasmans F, Wohlsein P, Grone A, Rijks JM (2011) Ranavirusassociated mass mortality in wild amphibians, the Netherlands, 2010: a first report. Vet J 190:284-286

Kimble SJ, Karna AK, Johnson AJ, Hoverman JT, Williams RN (2014) Mosquitoes as a Potential Vector of Ranavirus Transmission in Terrestrial Turtles. Ecohealth http://dx.doi.org/10.1007/ s10393-014-0974-3

Langdon JS (1989) Experimental transmission and pathogenicity of epizootic haematopoietic necrosis virus (EHNV) in redfin perch, Perca fluviatilis L., and 11 other teleosts. J Fish Dis 12:295-310

Langdon JS, Humphrey JD (1987) Epizootic haematopoietic necrosis, a new viral disease in redfin perch, Perca fluviatilis L., in Australia. J Fish Dis 10:289-297

Langdon JS, Humphrey JD, Williams LM, Hyatt AD, Westbury HA (1986) First virus isolation from Australian fish: an iridovirus-like pathogen from redfin perch, Perca fluviatilis L. J Fish Dis 9:263-268

Langdon JS, Humphrey JD, Williams LM (1988) Outbreaks of an EHNV-like iridovirus in cultured rainbow trout, Salmo gairdneri Richardson, in Australia. J Fish Dis 11:93-96

Lenski RE, May RM (1994) The evolution of virulence in parasites and pathogens: reconciliation between two competing hypotheses. J Theor Biol 169:253-265

Maceina MJ, Grizzle JM (2006) The relation of largemouth bass virus to largemouth bass population metrics in five Alabama reservoirs. Trans Am Fish Soc 135:545-555

Majji S, LaPatra S, Long SM, Sample R, Bryan L, Sinning A, Chinchar VG (2006) Rana catesbeiana virus z (RCV-Z): a novel pathogenic ranavirus. Dis Aquat Organ 73:1-11

Mao J, Green DE, Fellers G, Chinchar VG (1999) Molecular characterization of iridoviruses isolated from sympatric amphibians and fish. Virus Res 63:45-52

Marcogliese DJ, Pietrock M (2011) Combined effects of parasites and contaminants on animal health: parasites do matter. Trends Parasitol 27:123-130

Martin LB (2009) Stress and immunity in wild vertebrates: timing is everything. Gen Comp Endocrinol 163:70-76

May R, Nowak M (1994) Coinfection and the evolution of parasite virulence. Proc R Soc Lond B Biol Sci 255:81-89

Miller D, Gray M, Storfer A (2011) Ecopathology of ranaviruses infecting amphibians. Viruses 3:2351-2373

Moody NJG, Owens L (1994) Experimental demonstration of the pathogenicity of a frog virus, Bohle iridovirus, for a fish species, barramundi Lates calcarifer. Dis Aquat Organ 18:95-102

Morales HD, Abramowitz L, Gertz J, Sowa J, Vogel A, Robert J (2010) Innate immune responses and permissiveness to ranavirus infection of peritoneal leukocytes in the frog Xenopus laevis. J Virol 84:4912-4922

Muths E, Gallant AL, Campbell Grant EH, Battaglin WA, Green DE, Staiger JS, Walls SC, Gunzburger MS, Kearney RF (2006) The Amphibian Research and Monitoring Initiative (ARMI): 5-year report. Scientific investigations report 2006-5224. U.S. Geological Survey, Reston

Nagasawa K, Cruz-Lacierda ER (eds) (2004) Diseases of cultured groupers. Southeast Asian Fisheries Development Center, Aquaculture Department, Iloilo

Nazir J, Spengler M, Marschang RE (2012) Environmental persistence of amphibian and reptilian ranaviruses. Dis Aquat Organ 98:177-184

Parris MJ, Storfer A, Collins JP, Davidson EW (2005) Life-history responses to pathogens in tiger salamander (Ambystoma tigrinum) larvae. J Herpetol 39:366-372

Paull SH, Song S, McClure KM, Sackett LC, Kilpatrick AM, Johnson PT (2012) From superspreaders to disease hotspots: linking transmission across hosts and space. Front Ecol Environ $10: 75-82$ 
Pearman PB, Garner TWJ (2005) Susceptibility of Italian agile frog populations to an emerging strain of Ranavirus parallels population genetic diversity. Ecol Lett 8:401-408

Pearman PB, Garner TWJ, Straub M, Greber UF (2004) Response of the Italian agile frog (Rana latastei) to a ranavirus, frog virus 3: a model for viral emergence in naive populations. J Wildl Dis 40:660-669

Petranka JW, Murray SS, Kennedy CA (2003) Responses of amphibians to restoration of a southern Appalachian wetland: perturbations confound post-restoration assessment. Wetlands 23:278-290

Petranka JW, Harp EM, Holbrook CT, Hamel JA (2007) Long-term persistence of amphibian populations in a restored wetland complex. Biol Conserv 138:371-380

Pfennig DW, Loeb MLG, Collins JP (1991) Pathogens as a factor limiting the spread of cannibalism in tiger salamanders. Oecologia 88:161-166

Picco AM, Collins JP (2008) Amphibian commerce as a likely source of pathogen pollution. Conserv Biol 22:1582-1589

Picco AM, Karam AP, Collins JP (2010) Pathogen host switching in commercial trade with management recommendations. Ecohealth 7:252-256

Plumb JA, Zilberg D (1999a) Survival of largemouth bass iridovirus in frozen fish. J Aquat Anim Health 11:94-96

Plumb JA, Zilberg D (1999b) The lethal dose of largemouth bass virus in juvenile largemouth bass and the comparative susceptibility of striped bass. J Aquat Anim Health 11:246-252

Plumb JA, Grizzle JM, Young HE, Noyes AD, Lamprecht S (1996) An iridovirus isolated from wild largemouth bass. J Aquat Anim Health 8:265-270

Polis GA, Myers CA (1985) A survey of intraspecific predation among reptiles and amphibians. J Herpetol 19:99-107

Prasankok P, Chutmongkonkul M, Kanchanakhan S (2005) Characterisation of iridovirus isolated from diseased marbled sleepy goby, Oxyeleotris marmoratus. In: Walker P, Lester R, BondadReantaso MG (eds) Diseases in Asian aquaculture V. Fish Health Section, Asian Fisheries Society, Manila

Price S, Garner T, Nichols R, Balloux F, Ayres C, Mora-Cabello de Alba A, Bosch J (2014) Collapse of amphibian communities due to an introduced Ranavirus. Curr Biol 24:2586-2591

Qin QW, Chang SF, Ngoh-Lim GH, Gibson-Kueh S, Shi C, Lam TJ (2003) Characterization of a novel ranavirus isolated from grouper Epinephelus tauvina. Dis Aquat Organ 53:1-9

Raffel TR, Rohr JR, Kiesecker JM, Hudson PJ (2006) Negative effects of changing temperature on amphibian immunity under field conditions. Funct Ecol 20:819-828

Reddacliff LA, Whittington RJ (1996) Pathology of epizootic haematopoietic necrosis virus (EHNV) infection in rainbow trout (Oncorhynchus mykiss Walbaum) and redfin perch (Perca fluviatilis L). J Comp Pathol 115:103-115

Reeve BC, Crespi EJ, Whipps CM, Brunner JL (2013) Natural stressors and ranavirus susceptibility in larval wood frogs (Rana sylvatica). Ecohealth 10:190-200

Reilly SM, Lauder GV, Collins JP (1992) Performance consequences of a trophic polymorphism: feeding behavior in typical and cannibal phenotypes of Ambystoma tigrinum. Copeia (3):672-679

Restif O, Koella JC (2003) Shared control of epidemiological traits in a coevolutionary model of host-parasite interactions. Am Nat 161:827-836

Ridenhour BJ, Storfer AT (2008) Geographically variable selection in Ambystoma tigrinum virus (Iridoviridae) throughout the western USA. J Evol Biol 21:1151-1159

Robert J, Abramowitz L, Gantress J, Morales HD (2007) Xenopus laevis: a possible vector of ranavirus infection? J Wildl Dis 43:645-652

Robert J, George E, De Jesús Andino F, Chen G (2011) Waterborne infectivity of the Ranavirus frog virus 3 in Xenopus laevis. Virology 417:410-417

Rojas S, Richards K, Jancovich JK, Davidson EW (2005) Influence of temperature on ranavirus infection in larval salamanders, Ambystoma tigrinum. Dis Aquat Organ 63:95-100

Rollins-Smith LA (1998) Metamorphosis and the amphibian immune system. Immunol Rev 166:221-230 
Rollins-Smith LA (2009) The role of amphibian antimicrobial peptides in protection of amphibians from pathogens linked to global amphibian declines. Biochim Biophys Acta 1788:1593-1599

Roy BA, Kirchner JW (2000) Evolutionary dynamics of pathogen resistance and tolerance. Evolution 54:51-63

Ryder JJ, Miller MR, White A, Knell RJ, Boots M (2007) Host-parasite population dynamics under combined frequency- and density-dependent transmission. Oikos 116:2017-2026

Sabelis MW, Metz JAJ (2002) Taking stock: relating theory to experiment. In: Dieckmann U, Metz J, Sabelis M, Sigmund K (eds) Adaptive dynamics of infectious diseases: in pursuit of virulence management. Cambridge University Press, New York

Schloegel LM, Picco AM, Kilpatrick AM, Davies AJ (2009) Magnitude of the U.S. trade in amphibians and presence of Batrachochytrium dendrobatidis and ranavirus infection in imported North American bullfrogs (Rana catesbeiana). Biol Conserv 142:1420-1426

Schloegel LM, Daszak P, Cunningham AA, Speare R, Hill B (2010) Two amphibian diseases, chytridiomycosis and ranaviral disease, are now globally notifiable to the world organization for animal health (OIE): an assessment. Dis Aquat Organ 92:101-108

Schock DM, Bollinger TK, Chinchar VG, Jancovich JK, Collins JP (2008) Experimental evidence that amphibian ranaviruses are multi-host pathogens. Copeia 1:133-143

Sheafor B, Davidson EW, Parr L, Rollins-Smith L (2008) Antimicrobial peptide defenses in the salamander, Ambystoma tigrinum, against emerging amphibian pathogens. J Wildl Dis 44:226-236

Sheridan JF, Dobbs C, Brown D, Zwilling B (1994) Psychoneuroimmunology: stress effects on pathogenesis and immunity during infection. Clin Microbiol Rev 7:200-212

Southard GM, Fries LT, Terre DR (2009) Largemouth bass virus in Texas: distribution and management issues. J Aquat Anim Health 21:36-42

Speare R, Smith JR (1992) An iridovirus-like agent isolated from the ornate burrowing frog Limnodynastes ornatus in northern Australia. Dis Aquat Organ 14:51-57

St-Amour V, Wong WM, Garner TW, Lesbarrères D (2008) Anthropogenic influence on prevalence of 2 amphibian pathogens. Emerg Infect Dis 14:1175-1176

Stark T, Laurijssens C, Weterings M, Spitzen-van der Sluijs A, Martel A, Pasmans F (2014) Death in the clouds: ranavirus associated mortality in assemblage of cloud forest amphibians in Nicaragua. Acta Herpetol 9:125-127

Storfer A, Alfaro ME, Ridenhour BJ, Jancovich JK, Mech SG, Parris MJ, Collins JP (2007) Phylogenetic concordance analysis shows an emerging pathogen is novel and endemic. Ecol Lett 10:1075-1083

Sutton W, Gray M, Hoverman JT, Secrist R, Super P, Hardman R, Tucker J, Miller D (2014) Trends in ranavirus prevalence among plethodontid salamanders in the Great Smoky Mountains National Park. EcoHealth http://dx.doi.org/10.1007/s10393-014-0994-z

Teacher AGF, Garner TWJ, Nichols RA (2009) Population genetic patterns suggest a behavioural change in wild common frogs (Rana temporaria) following disease outbreaks (Ranavirus). Mol Ecol 18:3163-3172

Teacher AGF, Cunningham AA, Garner TWJ (2010) Assessing the long term impact of ranavirus infection in wild common frog populations. Anim Conserv 13:514-522

Terrell KA, Quintero RP, Murray S, Kleopfer JD, Murphy JB, Evans MJ, Nissen BD, Gratwicke B (2013) Cryptic impacts of temperature variability on amphibian immune function. J Exp Biol 216:4204-4211

Titus VR, Green TM (2013) Presence of Ranavirus in green frogs and eastern tiger salamanders on Long Island, New York. Herpetol Rev 44:266-267

Todd-Thompson M (2010) Seasonality, variation in species prevalence, and localized disease for Ranavirus in Cades Cove (Great Smoky Mountains National Park) amphibians. Dissertation, University of Tennesse, Knoxville

Tollrian R, Harvell D (1999) The ecology and evolution of inducible defenses. Princeton University Press, Princeton

Torrence SM, Green DE, Benson CJ, Ip HS, Smith LM, McMurry ST (2010) A new ranavirus isolated from Pseudacris clarkii tadpoles in playa wetlands in the southern high plains, Texas. J Aquat Anim Health 22:65-72 
Une Y, Sakuma A, Matsueda H, Nakai K, Murakami M (2009) Ranavirus outbreak in North American bullfrogs (Rana catesbeiana), Japan, 2008. Emerg Infect Dis 15(7):1146-1147

Waltzek TB, Miller DL, Gray MJ, Drecktrah B, Briggler JT, MacConnell B, Hudson C, Hopper L, Friary J, Yun SC, Malm KV, Weber ES, Hedrick RP (2014) New disease records for hatcheryreared sturgeon. I. Expansion of frog virus 3 host range into Scaphirhynchus albus. Dis Aquat Org 111:219-227

Warne RW, Crespi EJ, Brunner JL (2011) Escape from the pond: stress and developmental responses to ranavirus infection in wood frog tadpoles. Funct Ecol 25:139-146

Wheelwright NT, Gray MJ, Hill RD, Miller DL (2014) Sudden mass die-off of a large population of wood frog (Lithobates sylvaticus) tadpoles in Maine, USA, likely due to ranavirus. Herpetol Rev 45:240-242

Whittington RJ, Reddacliff GL (1995) Influence of environmental temperature on experimental infection of redfin perch (Perca fluviatilis) and rainbow trout (Oncorhynchus mykiss) with epizootic haematopoietic necrosis virus, an Australian iridovirus. Aust Vet J 72:421-424

Whittington RJ, Philbey A, Reddacliff GL, Macgown AR (1994) Epidemiology of epizootic hematopoietic necrosis virus (EHNV) infection in farmed rainbow trout, Oncorhynchus mykiss (Walbaum): findings based on virus isolation, antigen capture elisa and serology. J Fish Dis 17:205-218

Whittington RJ, Reddacliff LA, Marsh I, Kearns C, Zupanovic Z, Callinan RB (1999) Further observations on the epidemiology and spread of epizootic haematopoietic necrosis virus (EHNV) in farmed rainbow trout Oncorhynchus mykiss in southeastern Australia and a recommended sampling strategy for surveillance. Dis Aquat Organ 35:125-130

Whittington RJ, Becker JA, Dennis MM (2010) Iridovirus infections in finfish-critical review with emphasis on ranaviruses. J Fish Dis 33:95-122

Williams PD, Day T (2001) Interactions between sources of mortality and the evolution of parasite virulence. Proc R Soc Lond B Biol Sci 268:2331-2337

Williams T, Barbosa-Solomieu V, Chinchar VG (2005) A decade of advances in iridovirus research. Adv Virus Res 65:173-248

Woodland JE, Brunner CJ, Noyes AD, Grizzle JM (2002a) Experimental oral transmission of largemouth bass virus. J Fish Dis 25:669-672

Woodland JE, Noyes AD, Grizzle JM (2002b) A survey to detect largemouth bass virus among fish from hatcheries in the southeastern USA. Trans Am Fish Soc 131:308-311 


\title{
Ranavirus Replication: Molecular, Cellular, and Immunological Events
}

\author{
James K. Jancovich, Qiwei Qin, Qi-Ya Zhang, and V. Gregory Chinchar
}

\section{Introduction}

Since their discovery nearly 50 years ago, our understanding of ranavirus biology has developed in two distinct stages. The first, driven by the work of Allan Granoff, his collaborators, and other investigators in Europe and the USA, took place between 1965 and 1985. During this initial period, the principal events in ranavirus replication in cell culture were elucidated through the study of Frog virus 3 (FV3), the type species of the genus Ranavirus (family Iridoviridae). The second wave of ranavirus research began in the 1990s and continues to the present day. These studies, conducted in the USA and, increasingly, in Asia and Europe, are focused on ranavirus genes and genomes and have employed a variety of contemporary molecular approaches to ascertain the role of specific genes in viral replication. Moreover, current work has expanded beyond FV3 and has utilized additional ranavirus species as well as iridoviruses from other genera, especially the genus Megalocytivirus. Recent studies have identified viral genes that not only play direct structural and enzymatic roles in ranavirus replication, but also genes that likely enhance virus replication in

\footnotetext{
J.K. Jancovich

Department of Biological Sciences, California State University, San Marcos, CA 92096, USA

Q. Qin

Key Laboratory of Tropical Marine Bio-Resources and Ecology, South China Sea Institute of Oceanology, Chinese Academy of Sciences, Guangzhou, China

Q.-Y. Zhang

State Key Laboratory of Freshwater Ecology and Biotechnology, Institute of Hydrobiology, Chinese Academy of Sciences, Wuhan, Hubei, China

V.G. Chinchar $(\triangle)$

Department of Microbiology, University of Mississippi Medical Center, Jackson, MS 39216, USA

e-mail: vchinchar@umc.edu
} 
particular cellular and host environments, evade antiviral immune responses, and contribute to virulence. Ongoing studies involving the "knock out" of viral genes, "knock down" of gene function, and analysis of recombinant ranavirus proteins are providing a more complete understanding of viral gene function. Moreover, by identifying viral genes that play critical roles in virulence, these studies will provide a better understanding of protective innate and acquired immune responses in lower vertebrates and facilitate the development of effective anti-ranavirus vaccines. In addition to the biochemical and genetic studies that are the focus of this chapter, there has been an explosion of information describing the adverse impact that ranaviruses, and other vertebrate iridoviruses, have on wild and cultured ectothermic vertebrates (Duffus et al. 2015; Brunner et al. 2015). To provide a basis for understanding the molecular mechanisms of ranaviral disease, we describe below the salient events in ranavirus replication and the role of specific viral genes in this process. Although focused mainly on viral replication strategies as well as classical and contemporary methods for determining viral gene function, we also touch briefly on viral taxonomy and antiviral immune responses, two topics covered at length in other chapters within this book (Jancovich et al. 2015; Grayfer et al. 2015).

\section{Ranavirus Taxonomy and Genomes}

The genus Ranavirus is one of five genera within the family Iridoviridae (Table 1). The genera that comprise the family include two that infect only invertebrates, Iridovirus and Chloriridovirus, and three that target cold-blooded vertebrates, Ranavirus, Megalocytivirus, and Lymphocystivirus (Jancovich et al. 2012). Whereas megalocyti- and lymphocystiviruses infect only fish, ranaviruses, despite their eponymous designation, target fish, amphibians, and reptiles. Moreover, indicative of their broad host range, some ranaviruses infect hosts from different vertebrate classes. For example, Bohle iridovirus (BIV) is capable of infecting both amphibians and fish (Moody and Owens 1994). Viral promiscuity is especially evident in vitro where ranaviruses infect cells from multiple vertebrate species, including mammals. Iridovirids, a generic designation for all members of the family, possess an icosahedral capsid that encloses a dsDNA genome. A summary of iridovirid genomic features, including abbreviated species and isolate designations, is found in Table 1. As shown therein, genomes vary in size depending upon the specific virus, and contain between 92 and 211 putative open reading frames (ORFs) (Jancovich et al. 2012). Phylogenetic analysis of a set of 26 genes conserved among all members of the family support the division of the family into four distinct groups: Ranavirus, Megalocytivirus, Lymphocystivirus, and Iridovirus/Chloriridovirus (Eaton et al. 2007). Although not distinguished phylogenetically, iridoviruses and chloriridoviruses display marked differences in the percentage of guanine and cytosine $(\mathrm{G}+\mathrm{C})$ residues, virion size, and host range. Whether these features provide sufficient grounds for the current division into two genera remain to be determined.

Early studies on ranavirus genomes focused on FV3 and showed that it possessed a linear, double-stranded DNA genome that was circularly permutated and termi- 
Table 1 Iridovirus taxonomy: viral genera and species

\begin{tabular}{|c|c|c|c|c|c|}
\hline Genus & Species $^{\mathrm{a}}$ & Size (bp) & No. ORFs & $\% \mathrm{G}+\mathrm{C}$ & GenBank accession number \\
\hline \multirow[t]{2}{*}{ Iridovirus } & IIV-9 & 206,791 & 191 & 31 & GQ918152 \\
\hline & $I I V-6$ & 212,482 & 211 & 29 & AF303741 \\
\hline Chloriridovirus & $I I V-3$ & 191,132 & 126 & 48 & DQ643392 \\
\hline \multirow[t]{2}{*}{ Lymphocystivirus } & $L C D V-1$ & 102,653 & 108 & 29 & L63545 \\
\hline & LCDV-C & 186,250 & 178 & 27 & AY380826 \\
\hline \multirow[t]{11}{*}{ Ranavirus } & $A T V$ & 106,332 & 92 & 54 & AY150217 \\
\hline & FV3 & 105,903 & 97 & 55 & AY548484 \\
\hline & $E H N V$ & 127,011 & 100 & 54 & FJ433873 \\
\hline & ADRV & 106,734 & 101 & 55 & KC865735 \\
\hline & STIV & 105,890 & 103 & 55 & EU627010 \\
\hline & CMTV & 106,878 & 104 & 55 & JQ231222 \\
\hline & TFV & 105,057 & 105 & 55 & AF389451 \\
\hline & RGV & 105,791 & 106 & 55 & JQ654586 \\
\hline & ESV & 127,732 & 136 & 54 & JQ724856 \\
\hline & SGIV & 140,131 & 139 & 49 & AY521625 \\
\hline & GIV & 139,793 & 139 & 49 & AY666015 \\
\hline \multirow[t]{6}{*}{ Megalocytivirus } & ISKNV & 111,362 & 117 & 55 & AF371960 \\
\hline & RBIV & 112,080 & 116 & 53 & AY532606 \\
\hline & RSIV & 112,414 & 93 & 53 & BD143114 \\
\hline & OSGIV & 112,636 & 116 & 54 & AY894343 \\
\hline & TRBIV & 110,104 & 115 & 55 & GQ273492 \\
\hline & LYCIV & 111,760 & ND & ND & AY779031 \\
\hline
\end{tabular}

aIIV-9 invertebrate iridovirus type 9, IIV-6 invertebrate iridovirus type 6 (Chilo iridovirus), IIV-3 invertebrate iridovirus type 3, LCDV-1 lymphocystis disease virus 1, LCDV-C lymphocystis disease virus - China, TFV tiger frog virus, ATV Ambystoma tigrinum virus, FV3 Frog virus 3, RGV Rana grylio virus, $C M T V$ common midwife toad virus, $S T I V$ soft-shelled turtle iridovirus, ADRV Andrias davidianus ranavirus, EHNV epizootic haematopoietic necrosis virus, ESV European sheatfish virus, SGIV Singapore grouper iridovirus, GIV grouper iridovirus, ISKNV infectious spleen and kidney necrosis virus, RBIV rock bream iridovirus, RSIV red seabream iridovirus, OSGIV orange spotted grouper iridovirus, TRBIV turbot reddish body iridovirus, $L Y C I V$ large yellow croaker iridovirus. Viral names in bold italic type indicate species recognized by the International Committee on Taxonomy of Viruses; those in standard type are either tentative species or isolates of recognized species, $N D$ not determined

nally redundant, a characteristic of all viral genomes within the family Iridoviridae (Goorha and Murti 1982). In addition, the FV3 genome, as well as all other vertebrate iridoviruses with the exception of Singapore grouper iridovirus (SGIV), were shown to be highly methylated with each cytosine within every $\mathrm{CpG}$ dinucleotide methylated (Willis and Granoff 1980). While these early studies gave insight into the overall structure of ranavirus genomes, little was known about the genetic composition, coding capacity, and variations among ranavirus genomes.

As the second wave of ranavirus research built momentum, our understanding of ranavirus genomes quickly expanded. Beginning in 1997 with the sequencing of the genome for lymphocystis disease virus (Tidona and Darai 1997), complete genomic sequences were determined for a number of iridovirids, including multiple ranavirus species and isolates infecting a variety of hosts (Table 1). The availability of complete 
genomic sequence information permitted analysis of overall genomic organization, protein sequence variation, and polymorphic regions among ranaviruses.

Ranavirus genomes range in size from 105 to $140 \mathrm{kbp}$, display a $\mathrm{G}+\mathrm{C}$ content between 49 and $55 \%$, and are predicted to encode 92-139 viral proteins (Table 1). Currently, four unique genomic organizations, divisible into two groups, have been identified by dot plot and phylogenetic analyses of completely sequenced ranavirus genomes (Chen et al. 2013). Grouper iridovirus (GIV)-like ranaviruses (GIV and SGIV) comprise one group, while amphibian-like ranaviruses (ALRV) make up the second. GIV-like viruses display only short segments of genomic colinearity when compared to other members of the genus, whereas members of the ALRV group (i.e., ATV-, CMTV-, and FV3-like ranaviruses) share longer regions of colinearity (Jancovich et al. 2010; Chen et al. 2013; Mavian et al. 2012). However, among the three ALRV subgroups, inversion, deletions, and additions, have occurred that distinguish one from the other (Fig. 1).

Ranavirus genomes encode between 92 and 139 putative gene products that have been identified by detection of ORFs longer than 50 amino acids, SDS-
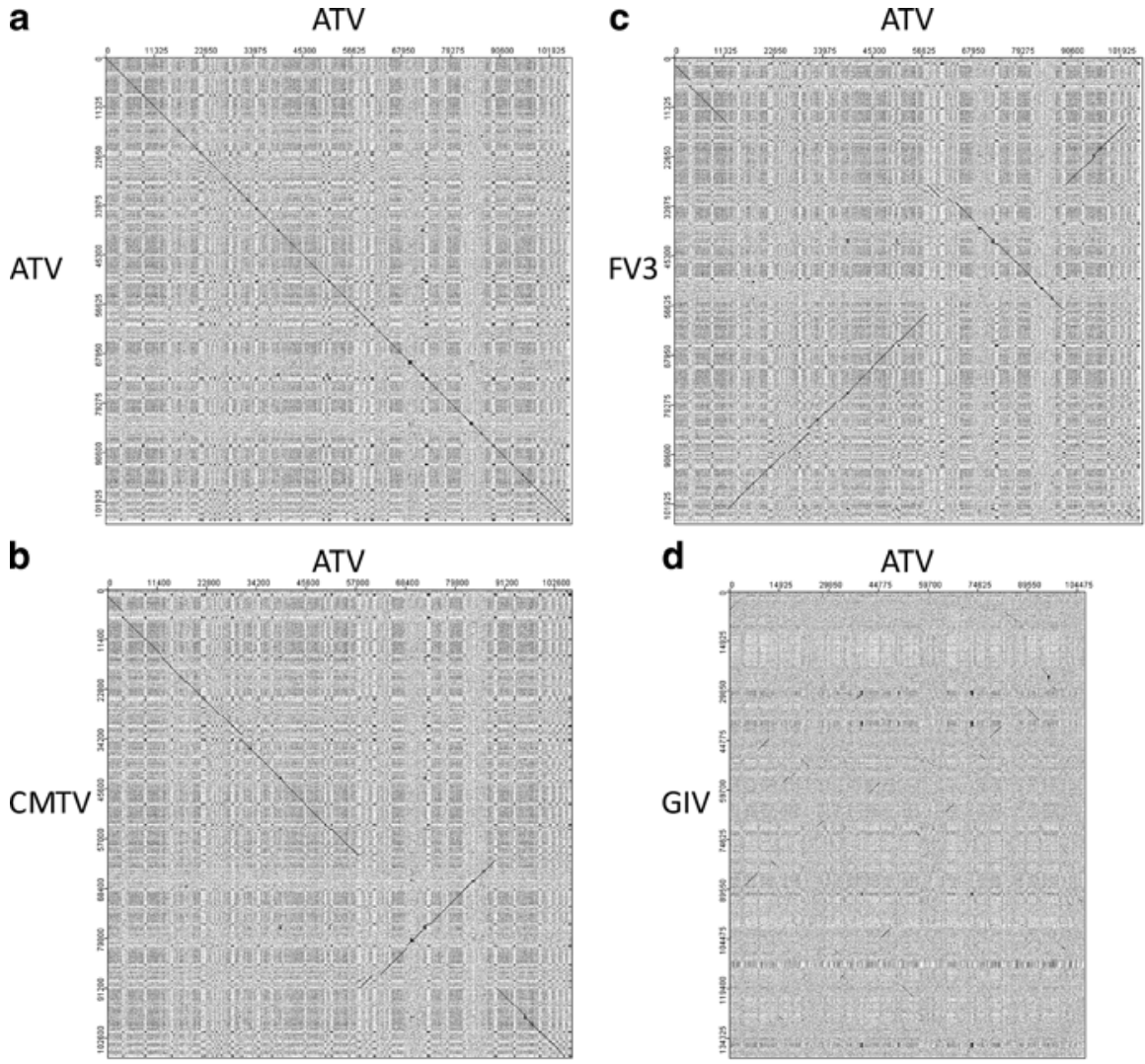

Fig. 1 Ranavirus genomic organization: Dotplot analysis of the genomic organization of representative members of the genus Ranavirus. The genomic sequence of ATV was compared to: (a) ATV; (b) CMTV; (c) FV3; (d) GIV. Dot plots were generated using JDotter (Brodie et al., 2004). Lines on the plot indicate regions of sequence similarity/colinearity 
polyacrylamide gel analysis of purified virions and virus-infected cells, microarray analysis of viral transcripts, and proteomic analysis of virions (Eaton et al. 2007; Majji et al. 2009; Song et al. 2006). The functions of about a third of these genes have been inferred by similarity to other known proteins or genes. Although the roles of the remaining genes are unknown, most are homologous to genes within the family Iridoviridae indicating that they play important roles in viral biogenesis. All ranaviruses contain 26 core iridovirus genes as well as an additional 72 genes that are common to all members of the genus (Eaton et al. 2007). Since the latter are found only among ranaviruses, we hypothesize that by identifying their various roles in replication we may be able to identify genes that function in unique host environments and cause disease in a wide variety of hosts.

In addition to coding regions, ranavirus genomes contain palindromes, microsatellites, repeat regions, and areas of inter- and intragenic variation (Eaton et al. 2010; Jancovich et al. 2003; Lei et al. 2012b; Mavian et al. 2012; Morrison et al. 2014; Tan et al. 2004). Repeat and variable regions may serve as sites that facilitate recombination or regulate gene expression, and palindromic sequences at the $3^{\prime}$ end of viral messages may act as transcriptional termination signals. In addition, comparisons of closely related FV3-like viruses that vary in virulence suggest that intragenic differences, as well as variation within repeated sequences, may influence viral pathogenesis (Morrison et al. 2014).

There is growing evidence that ranaviruses encode microRNAs (miRNAs) that regulate host and viral gene expression and play a role in the evasion of host antiviral immunity. For example, 11 of the 16 novel SGIV-encoded miRNAs identified by Illumina/Solexa deep-sequencing were present and functional in SGIV-infected grouper cells when examined by stem-loop quantitative RT-PCR and luciferase reporter assays (Yan et al. 2011). One miRNA, SGIV miR-homoHSV attenuated SGIV-induced apoptosis thereby enhancing virus replication (Guo et al. 2013). Taken together, these data suggest that sequence variations among ranavirus genomes may significantly influence ranavirus host range and pathogenesis. To that end, our understanding of ranavirus genomics will expand as additional ranavirus genomes are sequenced.

\section{Ranavirus Replication Strategy}

In this section, we discuss virus-encoded events that play direct roles in the production of infectious virus particles, and in the following sections the impact of virus infection on host cells and the interaction between the virus and host immune system. For the most part, ranavirus replication will be reviewed using FV3 as the model, but where appropriate other ranaviruses, or even viruses from other genera within the family, will be discussed. Key events in ranavirus replication are shown schematically in Fig. 2. While the events depicted in Fig. 2 are based, for the most part, on work with FV3, it appears that all vertebrate iridoviruses replicate using essentially the same general strategy. Differences among ranaviruses, megalocytiviruses, and lymphocystiviruses may reside in how they interact with their hosts at the cellular 


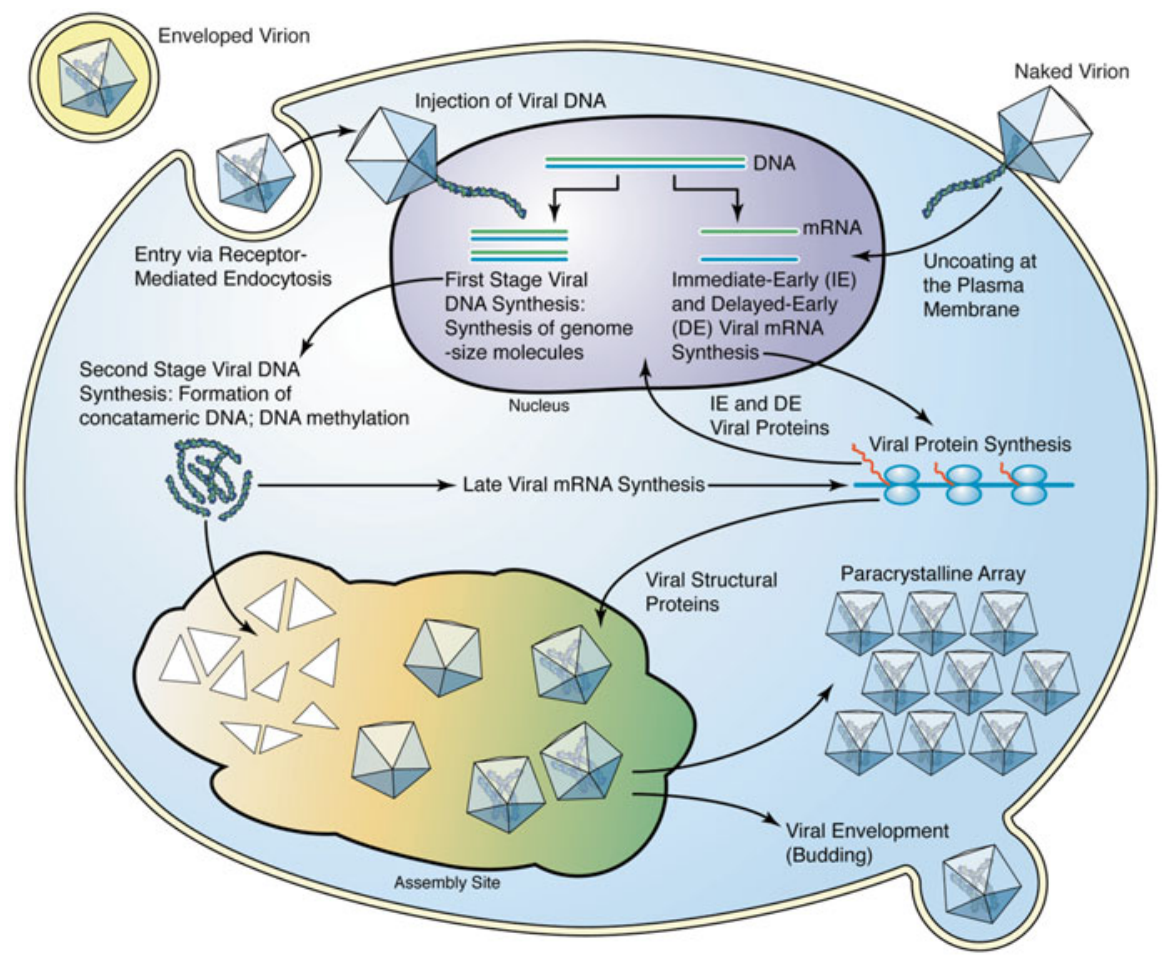

Fig. 2 Schematic diagram of ranavirus replication. Virions enter cells by one of two possible routes and initial events in virus replication (early viral transcription and the synthesis of unit length genomes) take place within the nucleus. Viral genomes are subsequently transported into the cytoplasm where they are methylated and serve as templates for concatemer formation. Viral assembly sites contain viral DNA and a number of virus-encoded proteins and serve as the loci of virion formation. Newly synthesized virions are found free within the cytoplasm or within paracrystalline arrays, and, a minority, at least in vitro, bud from the plasma membrane and in the process acquire an envelope

and immunological levels. Additional information on ranavirus replication strategies can be found in several comprehensive reviews (Chinchar et al. 2009, 2011; Williams 1996; Williams et al. 2005; Willis et al. 1985).

\subsection{Viral Entry}

Ranavirus particles are complex multilayered structures consisting, from inside out, of a core composed of the viral dsDNA genome associated with one or more virusencoded proteins, an internal lipid membrane containing several intramembrane proteins, an icosahedral capsid composed almost entirely of a $\sim 48 \mathrm{kDa}$ major capsid protein $(\mathrm{MCP})$, and (in those virions that are released by budding) a viral envelope 
derived from the aforementioned plasma membrane and containing one or more virus-encoded proteins (Darcy-Tripier et al. 1984). In appearance, ranavirus particles show marked similarity to the virions of African swine fever virus (ASFV) and members of the family Phycodnaviridae (Tulman et al. 2009; Wilson et al. 2009). In contrast to members of most other virus families whose infectious forms consist of either enveloped virions or non-enveloped viral particles, both non-enveloped and enveloped ranavirus particles are infectious. However, the infectivity of enveloped virions appears to be greater and may be a reflection of their entry via receptormediated endocytosis (Braunwald et al. 1979; Ma et al. 2014). Although ranaviruses possess broad in vitro and in vivo host ranges, the identities of the viral and cellular receptor proteins are not known. Non-enveloped virions interact with the plasma membrane and uncoating is thought to take place by release of the viral DNA core into the cytoplasm. In contrast, enveloped viruses are thought to enter cells by receptor-mediated endocytosis, followed by release of non-enveloped virions into the cytoplasm. Virions are transported to the nuclear membrane and viral DNA is subsequently injected into the nucleus (Braunwald et al. 1985; Gendrault et al. 1981). The enhanced infectivity of enveloped virions may reflect the more efficient binding of viral envelope protein(s) to the cellular receptor or more efficient uptake and release achieved by receptor-mediated endocytosis. In addition to these mechanisms, entry may also involve interaction between virions and caveolae (Guo et al. 2011b, 2012; Jia et al. 2013; Wang et al. 2014).

\subsection{Nuclear Events}

The entry of viral cores into the nucleus sets the stage for the opening acts of ranavirus replication: the synthesis of early viral transcripts and the generation of unit-length copies of the viral genome. As with other DNA viruses, such as herpesviruses, ranaviruses utilize host RNA polymerase II to transcribe viral messages (Goorha 1981). However, in contrast to herpesviruses, ranavirus transcription requires the presence of one or more virion-associated proteins and, as a result, deproteinized viral genomic DNA cannot be transcribed and is not infectious (Willis et al. 1990; Willis and Granoff 1985; Willis and Thompson 1986). The first viral transcripts synthesized are termed "immediate-early" (IE) and among their gene products are one or more proteins that are required for the synthesis of a second class of early transcripts, designated "delayed early" (DE) (Willis and Granoff 1978). As a group, IE and DE transcripts likely encode regulatory and virulence proteins as well as key catalytic proteins such as the large and small subunits of the viral homolog of RNA polymerase II (vPOL-II) and the viral DNA polymerase (Majji et al. 2009). Following microarray analysis of FV3 gene expression, 33 IE and 22 DE transcripts, corresponding to approximately half of the FV3 coding potential, were identified (Majji et al. 2009). Similar levels of IE and DE gene products were seen with other ranaviruses (Chen et al. 2006; Teng et al. 2008). Host POL-II is responsible for the transcription of IE (and perhaps DE) viral mRNAs, whereas, as described below, vPOL-II 
directs transcription of late viral messages. As with host transcripts, viral transcripts are capped and methylated, but unlike cellular messages ranavirus mRNAs lack poly[A] tails and introns.

\subsection{Cytoplasmic Events}

After its transport into the cytoplasm, viral DNA is methylated by a virus-encoded cytosine-specific DNA methyltransferase (DMTase) (Willis et al. 1984; Willis and Granoff 1980). Each cytosine within $\mathrm{CpG}$ dinucleotides is targeted leading to the methylation of 20-25\% of cytosines and resulting in the highest level of DNA methylation seen among vertebrate viruses. However, despite this extraordinary level of methylation, the precise role that methylation plays in the viral life cycle is not known. Methylation has been suggested to protect viral genomic DNA from attack by a virus-encoded restriction-modification enzyme that targets unmethylated host DNA (Kaur et al. 1995). Alternatively, methylation is thought to prevent recognition of viral genomic DNA by pattern recognition receptors such as TLR-9 and thus block activation of an immune response (Hoelzer et al. 2008; Krug et al. 2001, 2004). FV3 infection in the presence of $5^{\prime}$-azacytidine (azaC), a methylation inhibitor, does not affect viral transcription or translation, but results in modest decreases in DNA synthesis and marked reductions in viral yields (Goorha et al. 1984). In support of a protective role for DNA methylation, gradient analysis detected single-stranded DNA breaks in viral DNA synthesized in the presence of azaC. These breaks were thought to block DNA packaging and the development of infectious virions.

Within the cytoplasm, unit-length genomes serve as templates for the second stage of viral DNA synthesis which results in the formation of large concatemers containing ten or more interlaced copies of the viral genome (Goorha 1982). Using a collection of temperature-sensitive $(t s)$ mutants, two complementation groups, involving first stage and second stage DNA synthesis, have been linked to viral DNA synthesis (Chinchar and Granoff 1986; Goorha and Dixit 1984; Goorha et al. 1981). Since sequence analysis identified only a single viral DNA polymerase gene, it is likely that one complementation group encodes a viral DNA polymerase that functions in both events, whereas the second may encode a viral protein needed for the transport of viral DNA from the nucleus to the cytoplasm or some other function related to concatemer formation.

\subsection{Virus Assembly}

Virion formation takes place within morphologically distinct areas of the cytoplasm referred to as virus assembly sites or virus factories. Assembly sites are electron lucent areas of the cytoplasm that are devoid of cellular organelles (Murti et al. 1985, 1988; Zhang and Gui 2012). Unlike autophagosomes, ranavirus 

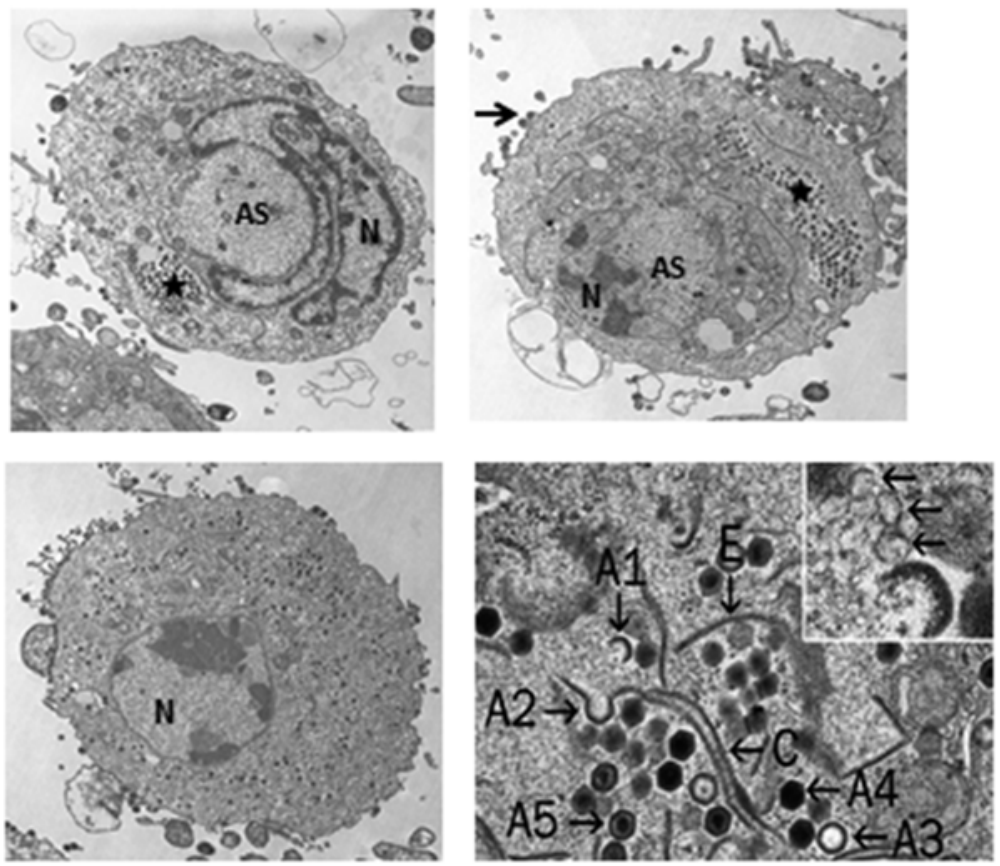

Fig. 3 Transmission electron micrographs of FV3-infected FHM cells. Upper left and right panels show typical virus-infected cells with nuclei $(\mathrm{N})$ showing evidence of chromatin condensation, well-defined viral assembly sites (AS); intracytoplasmic paracrystalline arrays (asterisk), and virions budding from the plasma membrane (arrow). Lower left panel shows a virus-infected cell in which virions are scattered throughout the cytoplasm. Lower right panel is an enlargement of a viral assembly site showing virions in various stages of assembly. Full (A4 and A5) and empty (A3) viral particles are shown as well as two possible intermediates (A1 and A2) and two aberrant forms $(\mathrm{C}$ and $\mathrm{E})$. The inset indicates membranes (arrows), possible originating from the ER, that play a role in virion morphogenesis

assembly sites are not enclosed within membranes, but are encased by intermediate filaments and surrounded by mitochondria and ribosomes (Fig. 3). Both early and late viral proteins are associated with assembly sites as well as presumably concatemeric viral DNA. Viral assembly sites were detected in the presence of an antisense morpholino oligonucleotide (asMO) that blocked late gene expression (Sample 2010; Sample et al. 2007). These results suggest that late viral protein expression is not required for assembly site development and strengthen an earlier study suggesting that early proteins are sufficient for assembly site formation (Chinchar et al. 1984; Sample 2010).

The specific steps required for the formation of infectious virus particles are still poorly understood. Genetic analysis of $t s$ mutants identified 12 complementation groups that synthesized ostensibly all viral proteins and viral DNA yet were unable to generate infectious particles (Chinchar and Granoff 1986). Transmission electron microscopic (TEM) analysis of these complementation groups identified several ts 
mutants in which virion structures did not form, whereas in others apparently complete, but noninfectious, particles were present (Purifoy et al. 1973; Sample 2010). Clearly multiple structural and catalytic proteins must be involved in the formation of infectious particles. By analogy to ASFV (Rouiller et al. 1998; Tulman et al. 2009), virion assembly may involve initial binding of a myristoylated viral protein (e.g., FV3 ORF53R) to fragments of the endoplasmic reticulum, followed by binding of the MCP on its opposite face (Whitley et al. 2010). Continued addition of $53 \mathrm{R}$ and $\mathrm{MCP}$ to membrane fragments is thought to result in the formation of crescent-shaped structures that eventually associate with viral DNA to form the virion. Consistent with this model, intermediates along the pathway to virion formation can be detected by transmission electron microscopy (Fig. 3).

The process by which viral DNA is encapsidated has not yet been determined. Although encapsidation of a "headful" of viral DNA explains the existence of circularly permuted, terminally redundant DNA genomes (Goorha and Murti 1982), it is not known if ranavirus DNA enters through a unique virion portal as seen with some dsDNA viruses or by engulfment of viral DNA by the enlarging icosahedron (Cardone et al. 2007; Chang et al. 2007). Moreover, although concatemeric DNA is thought to serve as the source of the DNA that is ultimately packaged into virions, how complete copies of the viral genome are resolved from concatemeric DNA is not known. Complete viral particles are present within viral assembly sites, the cytoplasm, paracrystalline arrays, and in association with the plasma membrane (Fig. 3). In cultured cells, most virions remain cell-associated and are released as naked particles following cell lysis. However, a variable number of particles bud from the plasma membrane and in the process acquire an envelope. The factors that determine whether a given particle remains cell-associated or enveloped are not known. Freeze-fracture electron microscopy indicates that mature FV3 particles display a Russian doll-like structure with a knobby, spherical core composed of viral DNA and associated proteins enclosed within a capsid composed primarily of a 48 kDa MCP (Darcy-Tripier et al. 1984; Devauchelle et al. 1985). Electron microscopy of Chilo iridescent virus (genus Iridovirus) has identified at least three minor proteins (designated finger, zip, and anchor) associated with the virion, but has not linked them with specific viral ORFs (Yan et al. 2009). In addition to the major and minor structural proteins, it is thought that other viral proteins, e.g., proteins responsible for translational shut-off and the transactivation of IE transcription, are also associated with mature virions. As described in Grayfer et al. (2015), these latter proteins may also contribute to virulence

In contrast to early viral messages that are, at least initially, transcribed in the nucleus by host POL-II, late viral messages such as those encoding the MCP and other virion-associated proteins may be transcribed within the cytoplasm by vPOL-II, a virus-encoded RNA polymerase whose two largest subunits are homologous to the corresponding units of cellular RNA polymerase II (Tan et al. 2004; Sample et al. 2007). As discussed below, knock down studies using an asMO targeted to vPOL-II $\alpha$ resulted in a marked reduction in the synthesis of all 
late proteins. At this time, it is not known if vPOL-II $\alpha$ and vPOL-II $\beta$ function as a minimal, two-subunit RNA polymerase, or whether these two viral subunits associate with other cellular or viral proteins to form the functional enzyme. In addition to the requirement for functional vPOL-II, late transcription is also dependent upon ongoing viral DNA synthesis as $t s$ mutants defective in viral DNA synthesis or treatment of FV3-infected cells with DNA synthesis inhibitors such as phosphonoacetic acid (PAA) or cytosine arabinoside (araC) also inhibit late viral gene expression (Chinchar and Granoff 1984, 1986). In cell culture, FV3 replication takes place within a $12-24 \mathrm{~h}$ period. Early messages are detectable within the first $4 \mathrm{~h}$; late transcripts and proteins, e.g., the MCP, by $8 \mathrm{~h}$ post infection; and virus particles by $8-12 \mathrm{~h}$. However, the kinetics of viral replication are influenced by the multiplicity of infection, temperature, and metabolic state of the host cell. As stated above, although all vertebrate iridoviruses are thought to replicate using the same general strategy, differences among them likely influence how they interact with their hosts at the cellular and immunological levels and impact replication in vivo.

\section{Impact of Virus Infection on the Host Cell}

\subsection{Cell Death: Necrosis, Apoptosis, and Parapoptosis}

Ranavirus infections result in the rapid inhibition of host DNA, RNA, and protein synthesis and culminate in rapid cell death (Goorha and Granoff 1979; Raghow and Granoff 1979). Interestingly, both infectious and noninfectious virions (i.e., heat- or UV-inactivated virus) trigger the turn off of cellular transcription and translation indicating that the "shut-off protein" is virion-associated (Cordier et al. 1981; Raghow and Granoff 1979). Furthermore, virus-infected cells undergo apoptosis as indicated by chromatin condensation and the fragmentation of cellular DNA (Chinchar et al. 2003). Apoptosis appears following either productive infection or infection by inactivated virions and may result from the prior inhibition of host cell macromolecular synthesis or the activation of protein kinase $\mathrm{R}$ (PKR). Ranavirusinduced apoptosis is dependent upon caspase activation and can be prevented by caspase inhibition (Chinchar et al. 2003).

In addition to apoptotic death, SGIV, the most phylogenetically distant member of the genus Ranavirus, triggers different forms of programmed cell death depending upon the cell type. In cultured grouper cells, a natural host for SGIV, infection triggers a nonapoptotic form of programmed cell death designated parapoptosis. Parapoptosis is characterized by the appearance of cytoplasmic vacuoles, distended endoplasmic reticulum, and the absence of DNA fragmentation, apoptotic bodies, and caspase activation. In contrast, in cells cultured from a non-host fish, e.g., fathead minnow (FHM), SGIV induces the typical form of apoptosis characterized by 
caspase activation and DNA fragmentation. Furthermore, disruption of mitochondrial transmembrane potential and externalization of phosphatidylserine (PS) are not detected in grouper cells but are seen in FHM cells after SGIV infection (Huang et al. 2011a). Similar results are obtained in GIV-infected grouper kidney cells. However, whether all ranaviruses modulate the survival of host and non-host cells differently requires further study (Pham et al. 2012). In host fish, mitogen-activated protein kinase (MAPK) cascades are involved in SGIV-induced parapoptosis, including extracellular signal-regulated kinase (ERK), p38 mitogen-activated protein kinase (p38 MAPK), and c-Jun N-terminal kinase (JNK) signaling (Huang et al. 2011a, b). Moreover, transcription of grouper immune genes, such as interferon regulatory factor 1 (IRF1), interleukin-8 (IL-8), and tumor necrosis factor alpha $(\mathrm{TNF}-\alpha)$ were regulated by JNK, while only $\mathrm{TNF}-\alpha$ was regulated by $\mathrm{p} 38$ MAPK. It is proposed that the JNK pathway is important for SGIV replication and modulates the inflammatory responses during virus infection (Huang et al. 2011b). Interestingly, activation of similar genes was seen following infection of FHM cells with FV3 (Cheng et al. 2014).

\subsection{Host Shut-Off and the Selective Expression of Viral Gene Products}

Despite the rapid inhibition of host macromolecular synthesis, viral DNA replication, transcription, and translation remain unaffected and abundant levels of infectious viral particles are produced within $24 \mathrm{~h}$ or less (Willis et al. 1985). The maintenance of viral protein synthesis in the face of the marked inhibition of cellular translation is likely the result of several factors. In the first place, a viral homolog of eukaryotic translational initiation factor $2 \alpha(\mathrm{vIF} 2 \alpha)$ acts as a pseudosubstrate, binds PKR, and prevents the phosphorylation and subsequent inactivation of cellular eIF2 $\alpha$ (Jancovich and Jacobs 2011). In addition, abundant levels of highly efficient viral messages outcompete host transcripts for access to the cellular translational machinery (Chinchar and Yu 1990a, b). In contrast, it is not clear how ranaviruses selectively inhibit host transcription. Perhaps ranaviruses target host POL-II as infection progresses, and rely upon vPOL-II to synthesize viral transcripts in the cytoplasm. If this model is correct, it would be instructive to determine whether early genes continue to be synthesized at later times using vPOL-II to catalyze their synthesis. As with transcription and translation, host DNA synthesis is also blocked. However, inhibition of host DNA synthesis is thought to be a consequence of the earlier blocks to cellular protein and RNA synthesis. Furthermore, a virus-encoded endonuclease, perhaps part of a restriction-modification system, is thought to degrade host DNA. Not only will this negatively impact host transcription, but the resulting nucleotides may also be re-utilized for the synthesis of viral DNA (Feighny et al. 1981; Kaur et al. 1995). 


\section{Interplay Between Host and Virus Determines the Outcome of Infection at the Organismal Level}

Virulence is a function of several factors but the two that are likely most important involve those that enhance virus replication and those that block host immune defenses. Large DNA viruses such as herpesviruses and poxviruses encode numerous genes that fulfill these functions and preliminary findings among ranaviruses suggest that they are no different (Eaton et al. 2007). In the case of viral genes that enhance replication, prime examples are viral homologs of the large and small subunits of ribonucleotide reductase (RR). Both Vaccinia virus (VACV) and herpes simplex virus 1 (HSV1) encode RR genes. VACV RR2 subunits form functional complexes with host RR1 and provide sufficient dNTPs for viral replication (Gammon et al. 2010). Likewise HSV and pseudorabies virus-encoded RR convert ribonucleoside diphosphates into the corresponding deoxyribonucleotides and play key roles in viral DNA synthesis by maintaining dNTP pool sizes (Conner et al. 1994a, b; Daikoku et al. 1991). Consistent with this key role in viral biogenesis, mutants defective in RR expression are avirulent in vivo (de Wind et al. 1993). However, in addition to their role in dNTP synthesis, HSV-1 and HSV-2 RR1 subunits also protect cells from apoptosis (Chabaud et al. 2007; Langelier et al. 2002). In contrast to the $\alpha$ - and $\beta$-herpesviruses, the RR1 subunit of murine cytomegalovirus is catalytically inactive and does not play a role in increasing dNTP pool sizes. Rather it has evolved a new function in which it inhibits RIP1, a cellular adaptor protein, and blocks signaling pathways involved in innate immunity and inflammation (Lembo and Brune 2009). Other viral genes that contribute to enhanced replication encode viral homologs of dUTPase and thymidine kinase (Eaton et al. 2007). It is likely that the RR1, RR2, dUTPase, and thymidine kinase homologs encoded by FV3 and other ranaviruses play similar critical roles in viral replication.

In addition to genes that enhance viral replication, viruses also encode genes that inhibit or counteract host immune responses. Poxviruses contain over two dozen genes whose sole function is to block one or more aspects of innate or acquired immunity (Seet et al. 2003), and it has been estimated the perhaps half of the genes encoded by human cytomegalovirus may be involved in immune evasion (Eberhardt et al. 2013). For example, poxviruses encode decoy receptors for IFN $\alpha / \beta$, IFN- $\gamma$, IL-1 $\beta$, IL-18, various chemokines, and complement that bind their cognate targets and downregulate their effector functions (Johnston et al. 2005; Johnston and McFadden 2003, 2004; Seet et al. 2003). In addition, virus-encoded miRNAs may also play critical roles in blocking host responses or controlling viral replication (Babu et al. 2014; Hook et al. 2014; Pavelin et al. 2013).

Sequence analysis of the genome of FV3 and other vertebrate iridoviruses has identified several putative genes that may play roles in blunting host immunity. These putative immune evasion proteins include the aforementioned viral homolog of eIF-2 $\alpha$ (vIF-2 $\alpha$ ), a viral homolog of RNAse III, a virus-encoded CARD (caspase activation and recruitment domain)-containing protein, a viral homolog of steroid 
dehydrogenase ( $\beta$-HSD), a viral Bcl-2 homolog, and one or more TNFR homologs (Huang et al. 2013b; Lin et al. 2008; Tan et al. 2004). In addition to these putative immune effectors, there are other viral genes that are unique to specific viruses or genera and may represent proteins that act only within specific host species, tissues, or cells. For example, there are a dozen open reading frames that are found only among ranaviruses that might encode unique polypeptides that enhance viral replication or impair immunity within specific ectothermic hosts (Eaton et al. 2007). However, the challenge of identifying virulence proteins by similarity searches is considerable. Because the level of similarity between viral and cellular homologs, even in mammalian systems, may be low, identification of a viral protein as a potential inhibitor of a specific function is far from certain unless key sequence motifs are conserved. For a given viral protein, conclusive evidence for a specific role in virulence will require using the genetic and biochemical approaches discussed below.

\section{Antiviral Immunity}

Because host antiviral immunity is discussed in Grayfer et al. (2015), only a brief summary will be presented here. The host immune response to ranavirus infection has been productively examined using a model pairing FV3, the best characterized ranavirus at the molecular level, with Xenopus laevis, the amphibian with the most fully characterized immune system (Robert 2010). Robert and colleagues have shown that infection of immunocompetent adult frogs is usually limited to the kidney and resolves with a few weeks with minimal mortality (Gantress et al. 2003). In contrast, tadpoles, which are naturally defective in MHC I expression, and immunocompromised adult animals, are susceptible to infection and display considerable morbidity and mortality (Tweedell and Granoff 1968; Gantress et al. 2003; Robert et al. 2005). In immunodeficient or immunocompromised Xenopus, infection begins in the kidney, but becomes systemic and spreads to multiple organs including the liver, gastrointestinal tract, and skin (Gantress et al. 2003). Consistent with observations that fish could be protected from ranavirus- and megalocytivirus-induced disease by vaccination with inactivated virions or a DNA vaccine (Caipang et al. 2006a, b; Ou-yang et al. 2012), antibody responses were shown to play a protective role in FV3 infections (Maniero et al. 2006). Likewise, cell-mediated immunity was shown to play an important role in protection from FV3-induced disease (Morales and Robert 2007). Recently macrophages were shown to be susceptible to FV3 infection (Morales et al. 2010). Although macrophages likely play a critical role in immunity, their infection may have two untoward effects: eliminating their ability to process and present viral antigens and providing a source of persistently infected cells that may facilitate the maintenance of virus in a population.

Although their roles in survival have yet to be determined, it is likely that multiple cellular genes that play various roles in antiviral immunity and virus replication are induced following ranavirus infection. Consistent with this suggestion, Cheng et al. (2014) recently examined the response of FHM cells to infection with 
either wild type FV3 or a knock out mutant lacking the ranavirus vIF-2 $\alpha$ and observed the induction of multiple immune-response genes at the transcriptional level including IFN, IL-8, GILT, IRF-3. Likewise, vaccination of groupers with inactivated SGIV induced the expression of numerous immune-related genes including Mx1, ISG15, IL-8, IL-1 $\beta$, and MHC I/II indicating that the immune response is conserved among different fish species and similar to that seen in mammals (Ou-yang et al. 2012).

Recently, Grayfer et al. (2014) reported the cloning and sequencing of interferon from Xenopus laevis ( $\mathrm{Xl}$-IFN). They showed that recombinant $\mathrm{Xl}$-IFN protected A6 amphibian cells from FV3 infection and transiently protected tadpoles. As expected, FV3-infected adults synthesized $\mathrm{Xl}$-IFN sooner and in higher amounts than tadpoles. Surprisingly, despite the more robust response of adults, viral burdens were greater in adults than tadpoles, although, as reported above, their long-term survival was higher. Moreover, although $\mathrm{Xl}$-IFN markedly impaired virus replication, it did not prevent death. Control, vector-treated tadpoles survived for an average of 26 days and experienced $90 \%$ mortality by day 32 , whereas $\mathrm{r} X l$-IFN-treated animals displayed a mean time to death of 36 days, with $90 \%$ mortality seen by day 40 . These results suggest that FV3 is more pathogenic to tadpoles than formerly thought and even low viral titers could cause extensive damage to internal organs and ultimately lead to death. In support of a protective role for IFN, transfection of a vector expressing turtle IFN- $\gamma$ into cultured STA cells was shown to result in an approximately $90 \%$ reduction in viral gene expression and a tenfold reduction in the yield of Softshell turtle iridovirus (Fu et al. 2014). Based on the results shown above, host immune responses seen after ranavirus infection are broadly similar to those seen in fish following infection with other viruses (Verrier et al. 2011).

\section{Determination of Viral Gene Function}

With the broad outlines of ranavirus replication known, the current challenge lies in elucidating the function of specific viral genes as this may provide targets for effective chemotherapy or aid in vaccine development. Determination of ranavirus gene function has accelerated markedly in the last 10 years as a variety of powerful molecular approaches have been brought to bear. These contemporary approaches, as well as more classical methodologies, are discussed below.

\subsection{Biochemical and Genetic Approaches}

The earliest attempts at identifying ranavirus gene function relied upon a combination of genetic and biochemical approaches. In the latter, various inhibitors were employed to block specific aspects of viral replication. For example, cycloheximide (CHX) blocked global protein synthesis and limited viral transcription to IE 
mRNAs, whereas flurophenylalanine (FPA), phosphonoacetic acid (PAA), and cytosine arabinoside (araC) permitted the expression of only IE and DE viral gene products (Goorha and Granoff 1979; Willis et al. 1985). It is thought that FPA is incorporated into one or more viral proteins required for late gene expression (e.g., the viral homologs of the two largest subunits of RNA polymerase II) and inhibits function by altering protein conformation. PAA and araC block viral DNA synthesis, an event that is required for full late gene expression, by specifically (e.g., PAA) or nonspecifically (e.g., araC) inhibiting viral DNA polymerase activity. The requirement for ongoing DNA replication for full late gene expression may reflect either the need for an increased number of, or conformationally altered, DNA templates.

The role of host RNA polymerase II in the transcription of early, but not late, viral mRNA was demonstrated using $\alpha$-amanitin, an inhibitor of host RNA polymerase II (Goorha 1981). When $\alpha$-amanitin was added before or at the time of infection, it blocked all viral gene expression. However, when added at late times, it had no effect on viral functions suggesting that host RNA polymerase II was only required at the beginning phase of infection (Goorha 1981). The critical role of DNA methylation in viral replication was explored using the methylation inhibitor, 5 '-azacytidine (azaC). In the presence of azaC, viral RNA and protein synthesis are not compromised, and viral DNA synthesis was only modestly affected (Goorha et al. 1984). However, in the presence of azaC, newly synthesized viral DNA lacked methylated cytosine residues and experienced single-stranded breaks. As a result, viral yields were reduced by more than a 100 -fold.

Although the above studies successfully elucidated the roles of several virusencoded proteins, because the inhibitors targeted a limited number of viral gene products (e.g., viral DNA polymerase, viral DNA methyltransferase), they were able to identify the roles of only a few of the approximately 100 putative FV3 ORFs. Attempts at identifying viral genes and their functions using traditional genetic approaches focused on the generation and characterization of drug-resistant $\left(\mathrm{PAA}^{\mathrm{R}}\right.$ and $\mathrm{azaC}^{\mathrm{R}}$ ) and temperature-sensitive $(t s)$ mutants. Characterization of an azaCresistant mutant linked a $26 \mathrm{kDa}$ protein to DMTase activity (Essani et al. 1987); studies using the PAA-resistant mutant confirmed that the drug target was the viral DNA polymerase (Chinchar and Granoff 1984). Temperature-sensitive mutants identified (via complementation analysis) 19 genes essential for viral replication (Chinchar and Granoff 1986; Naegele and Granoff 1971; Purifoy et al. 1973). These included mutants defective in RNA synthesis (five complementation groups) and viral DNA synthesis (two complementation groups). Analysis of the two DNAdeficient complementation groups supported the concept of two stages of DNA synthesis, i.e., the synthesis of unit size genomes within the nucleus, and the formation of large concatemers in the cytoplasm (Goorha and Dixit 1984; Goorha et al. 1981). The presence of at least five complementation groups displaying defects in late viral gene expression likely reflect mutations targeting the large and small subunits of viral RNA polymerase as well as other gene products required for late mRNA synthesis, e.g., transcription elongation factor SII. 
The majority of $t s$ mutants (12 complementation groups) synthesized both early and late viral proteins and viral DNA, but failed to form infectious particles at the nonpermissive temperature (Chinchar and Granoff 1986). This finding indicated that ranavirus particle assembly was not simply a concentration dependent event in which the MCP was the major, if not only, component. Electron microscopy showed that with some mutants outwardly mature but noninfectious virions were formed, whereas with others virion formation was aborted (Sample 2010). Given recent studies indicating that multiple proteins make up mature iridovirus virions (see above), it is likely that these defects reflect mutations in either critical structural proteins (e.g., MCP, 53R, anchor, finger, and zip proteins), putative scaffold proteins required for virus assembly, or in one or more virion-associated proteins required for the initiation of replication (e.g., the putative transactivator of IE transcription).

Attempts to map the genomic positions of $t s$ mutants have been challenging. Although the relative positions of a number of $t s$ mutants have been determined based on recombination frequencies (Chinchar and Granoff 1986), physical assignment of specific mutations to defined restriction fragments, as was done with herpesviruses and poxviruses, was unsuccessful. The inability of plasmids bearing ranavirus DNA to rescue $t s$ mutants is thought to be due to the degradation of input plasmid DNA by a virus-encoded endonuclease that targets unmethylated plasmid DNA. Fortunately, with complete sequencing of ATV, FV3 and other ranavirus genomes, alternative approaches for determining gene function have become available.

\subsection{Knock Down Strategies: Antisense Morpholino Oligonucleotides and RNA Interference}

Determination of the complete nucleotide sequence of FV3 and other ranavirus genomes has opened up the possibility of directly ascertaining gene function by targeting specific viral genes. Both knock down (KD, described here) and knock out (KO, described in the following section) have been used successfully. In the former, FV3 gene function was inhibited (i.e., knocked down) using either antisense morpholino oligonucleotides (asMOs) or small, interfering RNAs (siRNAs) (Sample et al. 2007; Whitley et al. 2010, 2011). asMOs are oligonucleotides ( 25 nucleotides in length) that are complementary to regions upstream of, or directly surrounding, the initiating AUG codon. They downregulate gene expression by blocking ribosomal movement ("scanning") and inhibiting protein synthesis (Hudziak et al. 2000; Summerton and Weller 1997; Summerton 2007). siRNAs are small ( 22 nucleotide) double-stranded molecules. Following their incorporation into an RNAinduced silencing complex, the strand complementary to the target message binds the target message leading to either RNA degradation or translational inhibition (Hannon 2002). In contrast to asMOs, siRNAs may bind within either coding or non-coding regions. Although algorithms exist to predict which sequences make effective siRNAs, they are not definitive and experimental validation of potential siRNAs must be carried out to ensure successful inhibition. 
Antisense morpholino oligonucleotides have been used successfully to target several FV3 genes, including those encoding the MCP, the $18 \mathrm{~K}$ immediate early protein, vPOL II $\alpha$, and 53R, a putative myristoylated membrane protein, as well as a SGIV-encoded histone-binding protein (Sample et al. 2007; Tran et al. 2011; Whitley et al. 2010, 2011). KD was verified by the absence or marked reduction of the target protein following SDS-PAGE or immunoblotting, and its effect on virus replication was monitored by transmission electron microscopy and determination of viral yields. KD of MCP and 53R resulted in marked reductions in the abundance of the target proteins, but had little to no effect on non-targeted proteins. Inhibiting the synthesis of MCP and 53R resulted in $\sim 90 \%$ reductions in virus yield and the appearance, respectively, of atypical elements (MCP) and granular particles (53R) within viral assembly sites. It is likely that a marked reduction in critical structural elements resulted in the accumulation of aberrant structures. In contrast to the above, KD of vPOL II $\alpha$ resulted in a global reduction in late protein synthesis and the absence of all structural elements within viral assembly sites. KD of the $18 \mathrm{~K} \mathrm{IE}$ protein only affected the target protein and had no adverse impact on virus yield. These results indicate that whereas MCP, 53R, and vPOL II $\alpha$ are essential proteins required for replication in vitro, $18 \mathrm{~K}$ is nonessential for replication in cultured FHM cells (Sample et al 2007; Whitley et al. 2010).

Attempts to extend these studies to other viral gene products were stymied by the inability to detect the loss of the targeted protein by either SDS-PAGE or immunoblotting. Nevertheless, we observed FV3 yields ranging from $8 \%$ (ORF 41R) to $43 \%$ (ORF 95R) of control following exposure to asMOs targeting ORF 2L (putative membrane protein), ORF 9L (NTPase/DEAD/H helicase), ORF 41R (an unknown protein, mol wt $129 \mathrm{kDa}$ ), ORF 32R (Neurofilament triplet H1 protein), ORF 38R (RR $\alpha)$, ORF 57R (Ser/Thr kinase), ORF 80L (Ribonuclease III-like protein), ORF 91R (46 kDa, immediate early protein), and ORF 95R (DNA repair protein, RAD2) (Whitley et al. 2011; VGC, unpublished observations). Partial yield reductions may reflect the fact that the targeted viral protein supplements an existing host function (e.g., ribonucleotide reductase) and may not be absolutely required for replication in cultured cells. Alternatively, a partial reduction may be due to incomplete KD. Moreover, the inability to confirm KD by SDS-PAGE may be due to either co-migration of the target protein with a more abundant protein of the same size (as was the case with 53R, Whitley et al. 2010) or its presence at only low levels in infected cells (Whitley et al. 2010). Although immunoblotting may be useful in identifying co-migrating or low abundance proteins, antibodies for detecting specific viral proteins are not readily available. Taken together KD studies have the potential for identifying three classes of viral proteins: (1) "essential" proteins that are absolutely required for virion production, e.g., the MCP and vPOL-II $\alpha$; (2) "efficiency" proteins that enhance virus replication in certain environments, e.g., viral homologs of ribonucleotide reductase, but that are not absolutely required for replication; and (3) "immune evasion" proteins that target innate and acquired components of the host antiviral immune response, e.g., viral homologs of eukaryotic translational initiation factor $2 \alpha(\mathrm{vIF}-2 \alpha)$ or $\beta$-hydroxysteroid dehydrogenase $(\beta-\mathrm{HSD})$. 
In addition to KD studies using asMOs, a limited number of studies have been conducted using siRNAs to silence viral gene expression (Dang et al. 2008; Kim et al. 2010; Whitley 2011; Xie et al. 2005). siRNA-mediated KD of FV3 MCP, vPOL-II $\alpha$, and the virus-encoded DNA methyltransferase markedly reduced levels of the cognate messages leading to $90 \%$ or greater reductions in virus yields, and showed little to no evidence of virion formation by transmission electron microscopy (Whitley et al. 2011; Xie et al. 2005). However, in contrast to KD mediated by asMOs, which could be detected following infection at multiplicities of infection (MOI) of 10 PFU/cell or higher, siRNA-mediated KD was only seen when MOIs of 0.01-0.1 were used. At higher inputs (i.e., MOI of 1-10), virus yields were not reduced by treatment with siRNAs. Although the reason for this inability is unclear, it is possible that ranaviruses, as do some other viruses, encode a gene product that blocks RNA interference (RNAi) perhaps by binding dsRNA and preventing its ability to form RNA silencing complexes.

Collectively, studies using siRNA and asMOs to inhibit the expression of specific viral genes have been extremely useful for elucidating viral gene function and determining whether a given gene is "essential" for replication in vitro. However, for viral genes that impact humoral and cell-mediated aspects of host immunity, siRNA and asMO approaches may not be suitable because the function of the targeted gene may only be required in vivo. For this reason, studies of putative virus-encoded immune evasion genes may be better suited for the knock out studies discussed below.

\subsection{Knock Out Mutants}

Until recently, ranavirus research has been limited by an inability to achieve recombination between an introduced plasmid and an infecting viral genome. This difficulty prevented the physical mapping of $t s$ mutants by marker rescue and the generation of recombinant viruses. Recently, methodologies utilizing efficient selection techniques capable of isolating rare recombinants have been developed. For example, recombinant SGIV, expressing enhanced green fluorescent protein (EGFP) fused to the envelope protein VP55, was constructed and used to evaluate the dynamics of viral replication (Huang et al. 2011c). Likewise, ranaviruses bearing drug resistance genes have been introduced into ATV, Rana grylio virus (RGV), and FV3 (see below). Thus, despite initial difficulties in generating recombinant ranaviruses, techniques based on the selection of fluorescent or drug-resistant viruses have emerged which allow their efficient isolation.

The first recombinant ranavirus was generated in BIV using homologous recombination to introduce the neomycin resistance gene under the control of the ICP18 promoter and the adult globin gene from Bufo marinus under the control of the promoter for the viral MCP into the vIF-2 $\alpha$ locus (Pallister et al. 2007). While not focused on characterizing the function of the vIF- $2 \alpha$ gene, the technology developed in this study facilitated the development of protocols for generating recombinant ranaviruses and confirmed the nonessential nature of the vIF- $2 \alpha$ gene product. 
Building on this study, knock-out (KO) and knock-in (KI) mutants have been generated in ATV, FV3, and RGV (Chen et al. 2011; He et al. 2012b; Huang et al. 2011c; Jancovich and Jacobs 2011). The first step in the generation of KO ranaviruses involves constructing a plasmid that contains a selectable marker flanked by sequences up- and downstream from the targeted gene. Cells are infected with wild type virus and subsequently transfected with the recombination construct. Homologous recombination within the flanking regions surrounding the selectable marker results in replacement of the targeted gene with a gene encoding the selectable marker. Recombinant viruses are isolated by their ability to replicate in the presence of the specific inhibitor (e.g., neomycin or puromycin) or by identifying fluorescent plaques, in those cases in which the green fluorescent protein (GFP) gene was introduced. Since viral and cellular growth are sensitive to neomycin and puromycin treatment, genes that confer resistance to these antibiotics have been used to select successfully KO ranaviruses (Jancovich and Jacobs 2011; Chen et al. 2011). In addition, GFP has been used as a selectable marker (Huang et al., 2011c). Once isolated, characterization of the $\mathrm{KO}$ mutant allows gene function to be determined by changes in phenotype. For example, replication of vIF- $2 \alpha \mathrm{KO}$ mutant in vitro was not significantly altered indicating that vIF- $2 \alpha$ is a nonessential gene (Chen et al. 2011; Jancovich and Jacobs 2011; Pallister et al. 2007). However, when frogs or salamanders were infected with the vIF- $2 \alpha \mathrm{KO}$ mutant, a reduction in host mortality was observed suggesting that vIF-2 $\alpha$ played an important role in vivo. In addition to the vIF $2 \alpha$ homologue, the viral $18 \mathrm{~K}$ immediate early gene has also been targeted (Chen et al. 2011). Deletion of the FV3 18K gene had little impact on viral replication in vitro but resulted in lower mortality in infected tadpoles, again suggesting that this gene was contributing to viral virulence. Preliminary characterization of two additional FV3 KO mutants targeting vCARD and $\beta$ HSD suggested that both were nonessential for replication in vitro ( $\mathrm{J}$ Robert and $\mathrm{G}$ Chen, University of Rochester, and VGC, unpublished observations). Collectively, these studies show the power of KO mutants in ascertaining the role of "nonessential" viral genes.

\subsection{Conditionally Lethal Mutants}

Because loss of an essential gene eliminates a virus's ability to replicate, KO strategies can only be directed against nonessential genes. There are two potential solutions to this impasse: (1) the construction of complementing cell lines that expresses the deleted gene product in trans and thus allow virus replication, and (2) the generation of conditionally lethal $(c l)$ mutants that fully express the targeted gene in the presence of the appropriate inducer (e.g., IPTG or tetracycline), but show little to no expression of the target gene in the absence of the inducer. Conditional lethal mutants have been constructed in African swine fever virus (ASFV, family Asfarviridae) and vaccinia virus (VACV, family Poxviridae; GarciaEscudero et al. 1998; Nichols et al. 2008), two virus families that along with members of the Iridoviridae, Ascoviridae, and Phycodnaviridae families comprise a 
group of phylogenetically related viruses termed, Nuclear Cytoplasmic Large DNA Viruses (Colson et al. 2012; Koonin and Yutin 2010).

Recently, Zhang and her co-workers have used homologous recombination to construct $c l$ mutants targeting the 53R and $2 \mathrm{~L}$ genes of the ranavirus, RGV (He et al. 2012b, 2013, 2014). Briefly, the lacI gene (encoding the lac repressor protein) under the control of the promoter for the ranavirus ICP18 immediate-early gene was introduced into the RGV TK gene by homologous recombination and a recombinant virus designated RGV-lacI was generated. Subsequently, the 53R or $2 \mathrm{~L}$ genes were placed under the control of a hybrid promoter (p50-lacO) in which the lac $O$ sequence (an "operator" sequence which when bound by the lacI repressor protein silences downstream transcription) is located immediately downstream of a TATA-like box within the promoter for RGV gene ORF50. A plasmid containing this construct was introduced into RGV-lacI via homologous recombination to generate the $c l$ mutants, i53R-RGV-lacIO and i2L-RGV-lacIO. In the absence of the inducer, IPTG, the lac repressor binds the lacO sequence and inhibits transcription of the downstream gene. In contrast, when the inducer is present, IPTG binds the repressor and relieves the transcriptional block allowing full expression of the viral gene product. In the case of the 53R and $2 \mathrm{~L} \mathrm{cl}$ mutants, expression of the targeted transcripts and proteins were markedly reduced, but not abolished, in the absence of IPTG. Thus, at $72 \mathrm{~h}$ after infection, virus yields were reduced more than $90 \%$ following a $75 \%$ reduction in the level of 53R transcripts. Similar results were seen with the $2 \mathrm{~L}$ mutant. Taken together these results indicate that both $53 \mathrm{R}$ and $2 \mathrm{~L}$ are essential for replication in vitro and that, as with ASFV and VACV, $c l$ mutants can be used to probe the function of essential viral genes. One potential drawback to their widespread use is that repression of the targeted gene is often not complete. However, as shown with both mutants, unless low level expression of the targeted gene is sufficient for full replication, the repression achieved (in the case of 53R, $75 \%$ at the transcriptional level) is sufficient to ascertain the essential nature of the gene product.

\subsection{Ectopic Expression of Recombinant Viral Proteins}

In addition to $\mathrm{KD}$ studies and studies using $t s, c l$, and $\mathrm{KO}$ mutants, another profitable way in which to explore viral gene function is by ectopically expressing recombinant viral proteins and monitoring their activity. Studies using this approach have been performed to determine the locations and functions of a number of ALRV proteins (e.g., vIF-2 $\alpha, \beta$-HSD, dUTPase, ERV1, 50L, 2L, and 53R) and are summarized immediately below and in Table 2 . The in vitro expression of recombinant viral proteins is especially useful in determining the role of catalytic proteins that impact cellular or immune functions, but less so with viral structural proteins or those that must interact with additional viral proteins for proper functioning.

$v I F-2 \alpha$. vIF-2 $\alpha$, a viral homolog of the alpha subunit of eukaryotic translational initiation factor 2 , is thought to play a critical role in maintaining viral protein 
Table 2 Assessment of Ranavirus gene function using recombinant proteins

\begin{tabular}{|c|c|c|}
\hline Gene (virus and ORF) ${ }^{\mathrm{a}}$ & Phenotype & Reference \\
\hline vIF-2 $\alpha(\mathrm{RCV})$ & $\begin{array}{l}\text { Maintains viral translation by blocking eIF- } 2 \alpha \\
\text { phosphorylation; found among most, but not all, } \\
\text { ranaviruses }\end{array}$ & $\begin{array}{l}\text { Rothenburg et al. } \\
\text { (2011) }\end{array}$ \\
\hline $\begin{array}{l}\text { ICP46 (SGIV ORF } \\
\text { 162L) }\end{array}$ & $\begin{array}{l}\text { Promotes GP cell growth and contributes to } \\
\text { SGIV replication as a structural protein of the } \\
\text { nucleocapsid }\end{array}$ & Xia et al. (2010) \\
\hline $\begin{array}{l}\text { ICP18 (SGIV ORF } \\
\text { 086R) }\end{array}$ & $\begin{array}{l}\text { Promotes GP cell growth and contributes to } \\
\text { SGIV replication as a viral non-envelope protein }\end{array}$ & Xia et al. (2009) \\
\hline $\begin{array}{l}\text { LITAF (SGIV ORF } \\
\text { 136R) }\end{array}$ & $\begin{array}{l}\text { Plays crucial roles in cell death by inducing } \\
\text { apoptosis }\end{array}$ & Huang et al. (2008) \\
\hline $\begin{array}{l}\text { LITAF (FV3 ORF } \\
\text { 75L) }\end{array}$ & $\begin{array}{l}\text { The C-terminal half of ORF 75L is markedly } \\
\text { similar to cellular LITAF; 75L and LITAF } \\
\text { associate in virus-infected cells }\end{array}$ & Eaton et al. (2013) \\
\hline $\begin{array}{l}\text { TNFR (SGIV ORF } \\
\text { 096R) }\end{array}$ & $\begin{array}{l}\text { Contributes to viral replication by modulating } \\
\text { the host apoptotic response }\end{array}$ & Huang et al. (2013b) \\
\hline $\begin{array}{l}\text { dUTPase (SGIV ORF } \\
\text { 049R) }\end{array}$ & Contains a nuclear export signal & Gong et al. (2010) \\
\hline $\begin{array}{l}\text { dUTPase (RGV ORF } \\
\text { 67R) }\end{array}$ & $\begin{array}{l}\text { Regulates levels of dUTP, contributes to } \\
\text { synthesis of dTTP and virus replication }\end{array}$ & Zhao et al. (2007) \\
\hline $\begin{array}{l}\text { H3 binding protein } \\
\text { (SGIV ORF 158L) }\end{array}$ & $\begin{array}{l}\text { Facilitates viral replication, and functions as a } \\
\text { histone } \mathrm{H} 3 \text { chaperone protein to control cellular } \\
\text { gene expression and viral replication }\end{array}$ & Tran et al. (2011b) \\
\hline $\begin{array}{l}\text { Viral Insulin-like } \\
\text { growth factor [IGF] } \\
\text { (SGIV ORF 062R) }\end{array}$ & $\begin{array}{l}\text { Stimulates cell growth and virus replication by } \\
\text { promoting G1/S transition; over-expression } \\
\text { leads to increased apoptosis in non-host cells }\end{array}$ & Yan et al. (2013) \\
\hline $\begin{array}{l}\text { Viral Semaphorin } \\
\text { (SGIV ORF 155R) }\end{array}$ & $\begin{array}{l}\text { Regulates host cytoskeletal structure and, } \\
\text { immune responses; facilitates viral replication. }\end{array}$ & Yan et al. (2014) \\
\hline $\begin{array}{l}\text { VP088 (SGIV ORF } \\
\text { 088) }\end{array}$ & $\begin{array}{l}\text { Plays a role in viral entry as a viral envelope } \\
\text { protein }\end{array}$ & Zhou et al. (2011) \\
\hline $\begin{array}{l}\text { VP019 (SGIV ORF } \\
\text { 019) }\end{array}$ & Viral envelope protein & Huang et al. (2013a) \\
\hline $\begin{array}{l}\text { VP18 (SGIV ORF } \\
\text { 018R) }\end{array}$ & $\begin{array}{l}\text { A putative Ser/Thr kinase; plays critical roles in } \\
\text { virion assembly and expression of viral late } \\
\text { genes }\end{array}$ & Wang et al. (2008a) \\
\hline ORF 38R (SGIV) & $\begin{array}{l}\text { Viral protein with an RGD motif; may play a } \\
\text { role in entry }\end{array}$ & Wan et al. (2010b) \\
\hline ORF 20R (TFV) & $\begin{array}{l}\text { Viral protein with an RGD motif; may play a } \\
\text { role in entry; similar to SGIV ORF } 38 \mathrm{R}\end{array}$ & Wang et al. (2008b) \\
\hline ORF 97R (FV3) & $\begin{array}{l}\text { The ORF 97R product localizes to the ER and } \\
\text { induces invagination of the ER and outer } \\
\text { nuclear membrane into the nucleus }\end{array}$ & Ring et al. (2013) \\
\hline $\begin{array}{l}\beta \text {-HSD (RGV ORF } \\
\text { 52L) }\end{array}$ & $\begin{array}{l}\text { Plays a key role in host steroid synthesis; } \\
\text { overexpression in EPC cells suppresses CPE }\end{array}$ & Sun et al. (2006) \\
\hline $\begin{array}{l}\text { ERV1/ALR (RGV } \\
\text { ORF88R) }\end{array}$ & $\begin{array}{l}\text { A sulfhydryl oxidase; by analogy to its ASFV } \\
\text { homolog, ERV1/ALR is thought to play a key } \\
\text { role in virion assembly }\end{array}$ & Ke et al. (2009) \\
\hline
\end{tabular}


Table 2 (continued)

\begin{tabular}{l|l|l}
\hline Gene (virus and ORF) & Phenotype & Reference \\
\hline 53R (RGV ORF 53R) & $\begin{array}{l}\text { Putative myristoylated membrane protein; plays } \\
\text { a key role in virion formation }\end{array}$ & $\begin{array}{l}\text { Kim et al. (2010), } \\
\text { Zhao et al. (2008) }\end{array}$ \\
\hline 50L (RGV ORF 50L) & $\begin{array}{l}\text { Virion-associated protein, plays roles in virus } \\
\text { assembly and viral gene expression }\end{array}$ & Lei et al. (2012a) \\
\hline 2L (RGV ORF2L) & $\begin{array}{l}\text { Putative membrane protein plays an essential } \\
\text { role in virus replication }\end{array}$ & He et al. (2014) \\
\hline
\end{tabular}

aViral gene products are identified either based on their putative function (e.g., dUTPase) or by reference to their FV3 homolog (e.g., ICP 46). In addition, the virus in which the gene product is found and the specific ORF are indicated. If the function is not known or homology to FV3 is not present, the gene is simply identified by its ORF designation

synthesis in the face of the global translational block triggered by dsRNA-activated PKR. vIF- $2 \alpha$ is hypothesized to act as a pseudosubstrate and, similar to VACV K3L, to bind PKR thereby preventing the phosphorylation and inactivation eIF- $2 \alpha$ (Beattie et al. 1991; Langland and Jacobs 2002). To demonstrate a role for vIF-2 $\alpha$ in maintaining viral protein synthesis in infected cells, Rothenburg et al. (2011) utilized a heterologous yeast system and showed that ectopic expression of vIF- $2 \alpha$ from the ranavirus, Rana catesbeiana virus-Z (RCV-Z), blocked the growth inhibiting effects of human and zebrafish PKR. RCV-Z vIF-2 $\alpha$ was shown to act as an inhibitor of both human and zebrafish PKR and block the PKR-mediated phosphorylation of eIF- $2 \alpha$, whereas VACV K3L displayed host specificity and only blocked the activity of human PKR. Moreover, experiments with vIF-2 $\alpha$ deletion constructs showed that the N-terminal and helical domains were sufficient for PKR inhibition whereas the C-terminal domain was dispensable. Because vIF-2 $\alpha$ does not substitute for eIF- $2 \alpha$ but instead inhibits PKR function, the authors suggested renaming it RIPR, Ranavirus Inhibitor of Protein kinase R. Although this study strengthens the view that vIF- $2 \alpha /$ RIPR is critical for maintaining viral protein synthesis in the face of a shut-off of host translation, it should be noted that both FV3 and soft-shell turtle iridovirus (STIV) encode truncated versions of vIF-2 $\alpha$ that are missing the N-terminal three-fourths of the full length product (Huang et al. 2009; Tan et al. 2004). The ability of both FV3 and STIV to turn off host translation and maintain high levels of viral protein synthesis indicate that although vIF- $2 \alpha$ is important for the maintenance of viral translation in the face of host shut-off, other proteins must also play a part in this process and perhaps, like the E3L/K3L system of VACV, provide a level of redundancy (Langland et al. 2006; Langland and Jacobs 2002).

$\beta H S D$. 3 $\beta$-Hydroxysteroid dehydrogenase plays a key role in cellular steroid synthesis and the corresponding VACV homolog is thought to play a critical role in blunting the host antiviral immune response (Reading et al. 2003). A 1,068 bp/355 amino acid $\beta$-HSD homolog of RGV was cloned and shown to be an immediate-early gene product (Sun et al. 2006). Confocal microscopy revealed that an ectopically expressed $\beta$ HSD-EGFP fusion protein co-localized exclusively with the mitochondrial marker 
pDsRed2-Mito in EPC cells. Moreover, overexpression of $\beta$ HSD-EGFP suppressed RGV-induced cytopathic effect (CPE) in EPC cells. Given the putative role of $\beta \mathrm{HSD}$ in steroid biosynthesis, it is likely that the role of this protein in a productive in vivo infection is to impair the host immune response. Whether $\beta$ HSD plays another role in vitro which allows it to suppress CPE remains to be determined. As seen with VACV mutants that lack $\beta$ HSD (Reading et al. 2003), we hypothesize that mutants targeting the $\beta \mathrm{HSD}$ gene will fail to inhibit the host immune response as fully as $w t$ virus and display an attenuated phenotype in vivo.

dUTPase (dUTP pyrophosphatase): dUTPase is a ubiquitous enzyme responsible for regulating dUTP concentrations (whose incorporation into DNA would be deleterious for virus replication) and raising levels of dTTP via the salvage pathway (Kato et al. 2014; Oliveros et al. 1999). dUTPase catalyzes the conversion of dUTP to dUMP. RGV-encoded dUTPase is a 164 amino acid protein that was characterized as an early gene product by RT-PCR and Western blot analysis. An ectopically expressed dUTPase-EGFP fusion protein was found within the cytoplasm, and immunofluorescence confirmed the cytoplasmic location of dUTPase in productively infected cells (Zhao et al. 2007). Overexpression of dUTPase had no detectable effect on RGV replication suggesting that it did not negatively or positively impact replication in vitro. Thus, at least in EPC cells, dUTPase overexpression does not enhance virus replication, perhaps because the level of expression provided by $w t$ virus is sufficient for full virus replication. In addition, studies of the SGIV dUTPase homolog identified a nuclear export signal that was crucial for the translocation of SGIV dUTPase from the nucleus to the cytoplasm (Gong et al. 2010). Lastly, although BLAST analysis suggests that RGV dUTPase functions in the control of dUTP/dTTP levels, dUTPase genes found within herpesviruses have evolved novel functions including the dysregulation of immune functions (Davison and Stow 2005; Glaser et al. 2006).

ERVI: The yeast protein ERV1 (Essential for Replication and Viability) and its mammalian homolog ALR (Augmenter of Liver Regeneration) are sulfhydryl oxidases that play critical roles in protein folding (Thorpe et al. 2002). Consistent with that role, ASFV contains an ERV1/ALR homolog, 9GL that is found within viral factories and plays a critical role in virion maturation (Lewis et al. 2000). A 9GL deletion mutant displayed a 2-log drop in viral yield, and, of the virions that formed, 90-99 \% contained acentric nucleoid structures. Like ASFV, the RGV ERV1 homo$\log (88 \mathrm{R})$ is a late protein (Ke et al. 2009). It contains the highly conserved ERV1 motif Cys-X-X-Cys and was detected in both the nucleus and cytoplasm. However, unlike the ASFV ERV1/ALR KO mutant, knock down of 88R expression by RNAi did not result in a drop in virus yield, suggesting either that ERV1 plays another role in virus replication, knock down was incomplete, or host cells retained sufficient sulfhydryl oxidase capacity to compensate for any defect in the viral enzyme.

50L: RGV 50L encodes a protein 499 amino acids in length with a predicted mol wt of $55.5 \mathrm{kDa}$. Full-length homologs ranging in size from 499 (STIV)—541 (EHNV) amino acids are present in a variety of ranaviruses, whereas a shorter homolog of 
249 amino acids encompassing only the C-terminal half of the protein is found in FV3. RGV 50L was cloned, expressed in E. coli, and used to prepare anti-50L antibody in mice. In addition, 50L was cloned into the eukaryotic expression vector pcDNA3.1, to yield 50L-pcDNA3.1 (Lei et al. 2012a). Immunofluorescent staining detected 50L within the cytoplasm, viral assembly sites, and nucleus. Moreover, the presence of 50L within the nucleus was dependent upon a nuclear localization signal within the central region of the protein. Infection of cells transfected with 50L-pcDNA3.1 displayed higher levels of 53R mRNA suggesting that 50L expression may affect the expression of RGV genes.

LITAF: Both SGIV and FV3 encode proteins with homology to a cellular protein designated LITAF, LPS-induced TNF $\alpha$ factor. LPS is a potent stimulator of monocytes and macrophages and triggers the secretion of TNF $\alpha$ and other proinflammatory cytokines. LITAF was identified as a novel transcriptional factor that modulated TNF $\alpha$ expression and played a role in the regulation of inflammatory cytokines (Tang et al. 2006). SGIV ORF136 encodes an early viral gene product that is a homolog of LITAF and which, following transfection of grouper cells with a vector expressing ORF136, is predominantly associated with mitochondria. Overexpression of SGIV LITAF in vitro induces apoptosis, as shown by increased apoptotic bodies, depolarization of mitochondrial membrane potential, and activation of caspase-3, suggesting that SGIV LITAF might play crucial roles in SGIVinduced cell death (Huang et al. 2008). Similar to SGIV ORF136, FV3 ORF 75L encodes a protein that shows high sequence similarity to a conserved domain found in the C-terminal half of cellular LITAF (Eaton et al. 2013). Following cotransfection or viral infection, cellular LITAF and FV3 75L were shown to co-localize to late endosomes/lysosomes within both baby green monkey cells (BGMK) and A6 amphibian cells. Interestingly, reexamination of SGIV ORF 136 confirmed localization to mitochondria within BGMK cells, but showed that, as with FV3 75L, SGIV ORF 136 localized to endosomes/lysosomes in amphibian A6 cells. To date, the exact function and temporal class of the viral LITAF homologs remain uncertain. It has been suggested that viral LITAF acts in a dominant-negative fashion to block the function of cellular LITAF (Eaton et al. 2013). If cellular LITAF does have an antiviral function, RNAi or asMO knock down of cellular LITAF levels should generate higher titers of FV3 in vitro and suggest a role for its viral homolog. Alternatively in vivo infection with a LITAF knock out mutant should result in an attenuated infection and lower viral titers.

RGD motif-containing proteins: Proteins containing the RGD motif are present among all iridovirid genera and include SGIV VP38 (Wan et al. 2010), Tiger frog virus ORF 20R (Wang et al. 2008b), and yellow croaker iridovirus (YCIV, genus Megalocytivirus) 037L (Ao and Chen 2006). Although differing markedly in size, all three genes contain an RGD motif that has been reported to play an important role in virus attachment and entry. In all three studies, recombinant protein was used to generate specific antiserum that was used to identify the protein within viral assembly sites and the viral envelope. Collectively, these studies indicate that RGDcontaining proteins are found within viral assembly sites and envelopes and may play 
a role in subsequent viral entry. However, suggestive of other roles, a YCIV-encoded thioredoxin-037L fusion protein was shown to induce cell rounding, detachment, and aggregation following its transfection into BF-2 cell monolayers. Additional ranavirus ORFs whose functions have been explored using recombinant proteins are described briefly below and summarized in Table 2 .

Additional Recombinant SGIV- and ISKNV-encoded Proteins. Vectors expressing the SGIV immediate-early (IE) genes, ORF162L and ORF086R, encoding putative homologs of FV3 ICP46 and ICP18, respectively, were constructed. Both gene products are distributed predominantly within the cytoplasm, and their overexpression promoted the growth of grouper embryonic cells and contributed to SGIV replication. SGIV ORF096 (VP96) encodes a putative homolog of TNFR, which contains two extracellular cysteine-rich domains (CRDs) but lacks the C-terminal transmembrane domain. Overexpression of ORF096 in vitro enhances cellular proliferation and improves cell survival suggesting that SGIV might utilize a viral homolog of TNFR to modulate the host apoptotic response for effective replication (Huang et al. 2013b). As with RGV, SGIV encodes a dUTPase homolog (ORF049R) with a leucine-rich nuclear export signal (NES) at its C-terminus. SGIV dUTPase is a cytoplasmic protein, and its NES is crucial for the translocation of dUTPase from the nucleus to the cytoplasm (Gong et al. 2010). SGIV ORF158L is observed in nuclei and virus assembly sites and its knock-down results in a significant decrease in virus yield in grouper embryonic (GP) cells. Further, analysis suggests that ORF158L may function as a histone $\mathrm{H} 3$ chaperon, enabling it to control host cellular gene expression and facilitate viral replication (Tran et al. 2011). ORF 158L is not found in all ranaviruses, but homologs displaying approximately $33 \%$ similarity to the SGIV product are found in EHNV, ADRV, and CMTV. SGIV ORF062R encodes a novel insulinlike growth factor that stimulates the growth of grouper GP cells and perhaps SGIV replication by promoting G1/S phase transition. In addition, overexpression of ORF062R slightly increased apoptosis in SGIV-infected non-host FHM cells (Yan et al. 2013). SGIV ORF155R encodes a semaphorin homolog, which could promote viral replication in vitro and attenuate the cellular immune response. Ectopically expressed ORF155R was shown to alter the cytoskeletal structure of fish cells. This alteration was characterized by a circumferential ring of microtubules near the nucleus and a disrupted microfilament organization (Yan et al. 2014). An abundant viral protein, ORF018R, has been identified which may play critical roles in serine/ threonine phosphorylation and virion assembly (Wang et al. 2008a). Two late genes, SGIV ORF088 and ORF019, encode viral envelope proteins. Furthermore, rVP88 was shown to bind a $94 \mathrm{kDa}$ host cell membrane protein, suggesting that VP88 might function as an attachment protein and play a role in viral entry (Huang et al. 2013a; Zhou et al. 2011). Finally, similar approaches have been applied to ISKNV (genus Megalocytivirus) and used to identify putative functions among a viral TRAF protein (He et al. 2012a), a viral protein that mediates formation of a mock basement membrane and provides attachment sites for lymphatic endothelial cells (Xu et al. 2010), a viral ankyrin repeat protein that may inhibit TNF $\alpha$-induced NF- $\kappa B$ signaling (Guo et al. 2011a), and a viral-encoded vascular endothelial growth factor 
(Wang et al. 2008c). Collectively, the generation and expression of recombinant viral proteins provides a powerful methodology for determining the cellular location and putative function of virus-encoded proteins.

\section{Final Thoughts}

Using contemporary molecular techniques, researchers are slowly elucidating the specific steps by which ranaviruses replicate in vitro and trigger disease in vivo. This work has been facilitated by pioneering studies performed with herpesviruses, poxviruses, and ASFV that have provided insights into which viral genes play important roles in virus replication and disease progression. Optimistically, identification of ranavirus genes that contribute to enhanced virus replication and the evasion of host immune responses will allow us to construct vaccines that are able to effectively protect endangered amphibians, fish, and reptiles. Success in this area is critical given the ongoing decline of amphibians in many parts of the world and the growing reliance upon mariculture and aquaculture as a source of protein for human consumption. In addition, understanding how viral genes interact and modulate immunological responses will broaden our understanding of immunity among "lower vertebrates" and shed light on the origins of the immune system.

Acknowledgments We thank Richard Condit (University of Florida) and Jacques Robert (University of Rochester Medical Center) for their careful review of this manuscript. This work was partially funded by the National Science Foundation (Award No. IOS 07-42711) and The University of Mississippi Medical Center (VGC); the National Major Basic Research Program (Award No. 2010CB126303), the National Natural Science Foundation of China (Award No. 31270213), and the Project of the State Key Laboratory of Freshwater Ecology and Biotechnology (Award No. 2011FBZ12) (QZ); the National Basic Research Program of China (973 Program, Award No. 2012CB114402), and the National Natural Science Foundation of China (Award No. 31330082) (QQ); and US National Institutes of Health (NIH) award 1R15-AI-101889-01 (JKJ).

Open Access publication was made possible through grants provided by the University of Tennessee (Institute of Agriculture, Office of Research and Engagement, and Department of Forestry, Wildlife and Fisheries), Washington State University Libraries, Gordon State College (Office of Academic Affairs), the Association of Reptilian and Amphibian Veterinarians, and the Amphibian and Reptile Conservancy.

Open Access This chapter is distributed under the terms of the Creative Commons Attribution Noncommercial License, which permits any noncommercial use, distribution, and reproduction in any medium, provided the original author(s) and source are credited.

\section{References}

Ao J, Chen X (2006) Identification and characterization of a novel gene encoding an RGDcontaining protein in large yellow croaker iridovirus. Virology 355:213-222

Babu SG, Pandeya A, Verma N, Shukla N, Kumar RV, Saxena S (2014) Role of HCMV miR-UL70-3p and miR-UL148D in overcoming the cellular apoptosis. Mol Cell Biochem 393:89-98 
Beattie E, Tartaglia J, Paoletti E (1991) Vaccinia virus-encoded eIF-2 alpha homolog abrogates the antiviral effect of interferon. Virology 183:419-422

Braunwald J, Tripier F, Kirn A (1979) Comparison of the properties of enveloped and naked frog virus 3 (FV3) particles. J Gen Virol 45:673-682

Braunwald J, Nonnenmacher H, Tripier-Darcy F (1985) Ultrastructural and biochemical study of frog virus 3 uptake by BHK-21 cells. J Gen Virol 66(pt 2):283-293

Brodie R, Roper RL, Upton C (2004) JDotter: a JAVA interface to multiple display plots generated by dotter. Bioinformatics 20:279-281

Brunner JL, Storfer A, Gray MJ, Hoverman JT (2015) Ranavirus ecology and evolution: from epidemiology to extinction. In: Gray MJ, Chinchar VG (eds) Ranaviruses: lethal pathogens of ectothermic vertebrates. Springer, New York

Caipang CM, Hirono I, Aoki T (2006a) Immunogenicity, retention and protective effects of the protein derivatives of formalin-inactivated red seabream iridovirus (RSIV) vaccine in red seabream, Pagrus major. Fish Shellfish Immunol 20:597-609

Caipang CM, Takano T, Hirono I, Aoki T (2006b) Genetic vaccines protect red seabream, Pagrus major, upon challenge with red seabream iridovirus (RSIV). Fish Shellfish Immunol 21:130-138

Cardone G, Winkler DC, Trus BL, Cheng N, Heuser JE, Newcomb WW, Brown JC, Steven AC (2007) Visualization of the herpes simplex virus portal in situ by cryo-electron tomography. Virology 361:426-434

Chabaud S, Sasseville AM, Elahi SM, Caron A, Dufour F, Massie B, Langelier Y (2007) The ribonucleotide reductase domain of the $\mathrm{R} 1$ subunit of herpes simplex virus type 2 ribonucleotide reductase is essential for R1 antiapoptotic function. J Gen Virol 88:384-394

Chang JT, Schmid MF, Rixon FJ, Chiu W (2007) Electron cryotomography reveals the portal in the herpesvirus capsid. J Virol 81:2065-2068

Chen LM, Wang F, Song W, Hew CL (2006) Temporal and differential gene expression of Singapore grouper iridovirus. J Gen Virol 87:2907-2915

Chen G, Ward BM, Yu KH, Chinchar VG, Robert J (2011) Improved knockout methodology reveals that Frog virus 3 mutants lacking either the $18 \mathrm{~K}$ immediate-early gene or the truncated $v I F-2$ alpha gene are defective for replication in vivo. J Virol 85:11131-11138

Chen Z, Gui J, Gao X, Pei C, Hong Y, Zhang Q (2013) Genome architecture changes and major gene variations of Andrias davidianus ranavirus (ADRV). Vet Res 44:101

Cheng K, Escalon BL, Robert J, Chinchar VG, Garcia-Reyero N (2014) Differential transcription of fathead minnow immune-related genes following infection with frog virus 3 , an emerging pathogen of ectothermic vertebrates. Virology 456-457:77-86

Chinchar VG, Granoff A (1984) Isolation and characterization of a frog virus 3 variant resistant to phosphonoacetate: genetic evidence for a virus-specific DNA polymerase. Virology 138:357-361

Chinchar VG, Granoff A (1986) Temperature-sensitive mutants of frog virus 3: biochemical and genetic characterization. J Virol 58:192-202

Chinchar VG, Yu W (1990a) Frog virus 3-mediated translational shut-off: frog virus 3 messages are translationally more efficient than host and heterologous viral messages under conditions of increased translational stress. Virus Res 16:163-174

Chinchar VG, Yu W (1990b) Translational efficiency: iridovirus early mRNAs outcompete tobacco mosaic virus message in vitro. Biochem Biophys Res Commun 172:1357-1363

Chinchar VG, Goorha R, Granoff A (1984) Early proteins are required for the formation of frog virus 3 assembly sites. Virology 135:148-156

Chinchar VG, Bryan L, Wang J, Long S, Chinchar GD (2003) Induction of apoptosis in frog virus 3-infected cells. Virology 306:303-312

Chinchar VG, Hyatt A, Miyazaki T, Williams T (2009) Family Iridoviridae : poor viral relations no longer. Curr Top Microbiol Immunol 328:123-170

Chinchar VG, Yu KH, Jancovich JK (2011) The molecular biology of frog virus 3 and other iridoviruses infecting cold-blooded vertebrates. Viruses 3:1959-1985

Colson P, de Lamballerie X, Fournous G, Raoult D (2012) Reclassification of giant viruses composing a fourth domain of life in the new order Megavirales. Intervirology 55:321-332 
Conner J, Cross A, Murray J, Marsden H (1994a) Identification of structural domains within the large subunit of herpes simplex virus ribonucleotide reductase. J Gen Virol 75(pt 12): $3327-3335$

Conner J, Marsden H, Clements BH (1994b) Ribonucleotide reductase of herpesviruses. Rev Med Virol 4:25-34

Cordier O, Aubertin AM, Lopez C, Tondre L (1981) Inhibitiion de la traduction par le FV3: action des proteines virales de structure solubilisees sur la synthese proteique in vivo et in vitro. Ann Virol (Inst Pasteur) 132 E:25-39

Daikoku T, Yamamoto N, Maeno K, Nishiyama Y (1991) Role of viral ribonucleotide reductase in the increase of dTTP pool size in herpes simplex virus-infected Vero cells. J Virol 72:1441-1444

Dang LT, Kondo H, Hirono I, Aoki T (2008) Inhibition of red seabream iridovirus (RSIV) replication by small interfering RNA (siRNA) in a cell culture system. Antiviral Res 77:142-149

Darcy-Tripier F, Nermut MV, Braunwald J, Williams LD (1984) The organization of frog virus 3 as revealed by freeze-etching. Virology 138:287-299

Davison AJ, Stow ND (2005) New genes from old: redeployment of dUTPase by herpesviruses. J Virol 79:12880-12892

de Wind N, Berns A, Gielkens A, Kimman T (1993) Ribonucleotide reductase-deficient mutants of pseudorabies virus are avirulent for pigs and induce partial protective immunity. J Gen Virol 74(pt 3):351-359

Devauchelle G, Stoltz DB, Darcy-Tripier F (1985) Comparative ultrastructure of iridoviridae. Curr Top Microbiol Immunol 116:1-21

Duffus ALJ, Waltzek TB, Stöhr AC, Allender MC, Gotesman M, Whittington RJ, Hick P, Hines MK, Marschang RE (2015) Distribution and host range of ranaviruses. In: Gray MJ, Chinchar VG (eds) Ranaviruses: lethal pathogens of ectothermic vertebrates. Springer, New York

Eaton HE, Metcalf J, Penny E, Tcherepanov V, Upton C, Brunetti CR (2007) Comparative genomic analysis of the family Iridoviridae: re-annotating and defining the core set of iridovirus genes. Virol J 4:11

Eaton HE, Ring BA, Brunetti CR (2010) The genomic diversity and phylogenetic relationship in the family iridoviridae. Viruses 2:1458-1475

Eaton HE, Ferreira Lacerda A, Desrochers G, Metcalf J, Angers A, Brunetti CR (2013) Cellular LITAF interacts with frog virus $375 \mathrm{~L}$ protein and alters its subcellular localization. J Virol 87:716-723

Eberhardt MK, Deshpande A, Chang WL, Barthold SW, Walter MR, Barry PA (2013) Vaccination against a virus-encoded cytokine significantly restricts viral challenge. J Virol 87:11323-11331

Essani K, Goorha R, Granoff A (1987) Mutation in a DNA-binding protein reveals an association between DNA-methyltransferase activity and a 26,000-Da polypeptide in frog virus 3-infected cells. Virology 161:211-217

Feighny RJ, Henry BE II, Pagano JS (1981) Epstein-Barr virus-induced deoxynuclease and the reutilization of host-cell DNA degradation products in viral DNA replication. Virology 115:395-400

Fu JP, Chen SN, Zou PF, Huang B, Guo Z, Zeng LB, Qin QW, Nie P (2014) IFN-gamma in turtle: conservation in sequence and signalling and role in inhibiting iridovirus replication in Chinese soft-shelled turtle Pelodiscus sinensis. Dev Comp Immunol 43:87-95

Gammon DB, Gowrsihankar B, Duraffour S, Andrei G, Upton C, Evans DH (2010) Vaccinia virusencoded ribonucleotide reductase subunits are differentially required for replication and pathogenesis. PLoS Pathog 6:e1000984

Gantress J, Maniero GD, Cohen N, Robert J (2003) Development and characterization of a model system to study amphibian immune responses to iridoviruses. Virology 311:254-262

Garcia-Escudero R, Andres G, Almazan F, Vinuela E (1998) Inducible gene expression from African swine fever virus recombinants: analysis of the major capsid protein p72. J Virol $72: 3185-3195$

Gendrault JL, Steffan AM, Bingen A, Kirn A (1981) Penetration and uncoating of frog virus 3 (FV3) in cultured rat Kupffer cells. Virology 112:375-384 
Glaser R, Litsky ML, Padgett DA, Baiocchi RA, Yang EV, Chen M, Yeh PE, Green-Church KB, Caligiuri MA, Williams MV (2006) EBV-encoded dUTPase induces immune dysregulation: implications for the pathophysiology of EBV-associated disease. Virology 346:205-218

Gong J, Huang YH, Huang XH, Zhang R, Qin QW (2010) Nuclear-export-signal-dependent protein translocation of dUTPase encoded by Singapore grouper iridovirus. Arch Virol 155:1069-1076

Goorha R (1981) Frog virus 3 requires RNA polymerase II for its replication. J Virol 37:496-499

Goorha R (1982) Frog virus 3 DNA replication occurs in two stages. J Virol 43:519-528

Goorha R, Dixit P (1984) A temperature-sensitive (TS) mutant of frog virus 3 (FV3) is defective in second-stage DNA replication. Virology 136:186-195

Goorha R, Granoff A (1979) Icosahedral cytoplasmic deoxyriboviruses. In: Fraenkel-Conrat H, Wagner RR (eds) Comprehensive virology. Plenum Press, New York, pp 347-399

Goorha R, Murti KG (1982) The genome of frog virus 3, an animal DNA virus, is circularly permuted and terminally redundant. Proc Natl Acad Sci U S A 79:248-252

Goorha R, Willis DB, Granoff A, Naegele RF (1981) Characterization of a temperature-sensitive mutant of frog virus 3 defective in DNA replication. Virology 112:40-48

Goorha R, Granoff A, Willis DB, Murti KG (1984) The role of DNA methylation in virus replication: inhibition of frog virus 3 replication by 5-azacytidine. Virology 138:94-102

Grayfer L, De Jesús Andino F, Robert J (2014) The amphibian (Xenopus laevis) type I interferon response to Frog Virus 3: new insight into ranavirus pathogenicity. J Virol 88:5766-5777

Grayfer L, Edholm E-S, De Jesús Andino F, Chinchar VG, Robert J (2015) Ranavirus host immunity and immune evasion. In: Gray MJ, Chinchar VG (eds) Ranaviruses: lethal pathogens of ectothermic vertebrates. Springer, New York

Guo CJ, Chen WJ, Yuan LQ, Yang LS, Weng SP, Yu XQ, He JG (2011a) The viral ankyrin repeat protein (ORF124L) from infectious spleen and kidney necrosis virus attenuates nuclear factor\{kappa\}B activation and interacts with I $\{$ kappa\}B kinase \{beta\}. J Gen Virol 92:1561-1570

Guo CJ, Liu D, Wu YY, Yang XB, Yang LS, Mi S, Huang YX, Luo YW, Jia KT, Liu ZY, Chen WJ, Weng SP, Yu XQ, He JG (2011b) Entry of tiger frog virus (an Iridovirus) into HepG2 cells via a pH-dependent, atypical, caveola-mediated endocytosis pathway. J Virol 85:6416-6426

Guo CJ, Wu YY, Yang LS, Yang XB, He J, Mi S, Jia KT, Weng SP, Yu XQ, He JG (2012) Infectious spleen and kidney necrosis virus (a fish iridovirus) enters Mandarin fish fry cells via caveoladependent endocytosis. J Virol 86:2621-2631

Guo C, Yan Y, Cui H, Huang X, Qin Q (2013) miR-homoHSV of Singapore grouper iridovirus (SGIV) inhibits expression of the SGIV pro-apoptotic factor LITAF and attenuates cell death. PLoS One 8:e83027

Hannon GJ (2002) RNA interference. Nature 418:244-251

He BL, Yuan JM, Yang LY, Xie JF, Weng SP, Yu XQ, He JG (2012a) The viral TRAF protein (ORF111L) from infectious spleen and kidney necrosis virus interacts with TRADD and induces caspase 8-mediated apoptosis. PLoS One 7:e37001

He LB, Ke F, Zhang QY (2012b) Rana grylio virus as a vector for foreign gene expression in fish cells. Virus Res 163:66-73

He LB, Gao XC, Ke F, Zhang QY (2013) A conditional lethal mutation in Rana grylio virus ORF 53R resulted in a marked reduction in virion formation. Virus Res 177:194-200

He LB, Ke F, Wang J, Gao XC, Zhang QY (2014) Rana grylio virus (RGV) envelope protein 2L: subcellular localization and essential roles in virus infectivity revealed by conditional lethal mutant. J Gen Virol 95:679-690

Hoelzer K, Shackelton LA, Parrish CR (2008) Presence and role of cytosine methylation in DNA viruses of animals. Nucleic Acids Res 36:2825-2837

Hook LM, Grey F, Grabski R, Tirabassi R, Doyle T, Hancock M, Landais I, Jeng S, McWeeney S, Britt W, Nelson JA (2014) Cytomegalovirus miRNAs target secretory pathway genes to facilitate formation of the virion assembly compartment and reduce cytokine secretion. Cell Host Microbe 15:363-373

Huang X, Huang Y, Gong J, Yan Y, Qin Q (2008) Identification and characterization of a putative lipopolysaccharide-induced TNF-alpha factor (LITAF) homolog from Singapore grouper iridovirus. Biochem Biophys Res Commun 373:140-145 
Huang Y, Huang X, Liu H, Gong J, Ouyang Z, Cui H, Cao J, Zhao Y, Wang X, Jiang Y, Qin Q (2009) Complete sequence determination of a novel reptile iridovirus isolated from soft-shelled turtle and evolutionary analysis of Iridoviridae. BMC Genomics 10:224

Huang X, Huang Y, OuYang Z, Cai J, Yan Y, Qin Q (2011a) Roles of stress-activated protein kinases in the replication of Singapore grouper iridovirus and regulation of the inflammatory responses in grouper cells. J Gen Virol 92:1292-1301

Huang X, Huang Y, Ouyang Z, Xu L, Yan Y, Cui H, Han X, Qin Q (2011b) Singapore grouper iridovirus, a large DNA virus, induces nonapoptotic cell death by a cell type dependent fashion and evokes ERK signaling. Apoptosis 16:831-845

Huang Y, Huang X, Cai J, Ye F, Guan L, Liu H, Qin Q (2011c) Construction of green fluorescent protein-tagged recombinant iridovirus to assess viral replication. Virus Res 160:221-229

Huang X, Gong J, Huang Y, Ouyang Z, Wang S, Chen X, Qin Q (2013a) Characterization of an envelope gene VP19 from Singapore grouper iridovirus. Virol J 10:354

Huang X, Huang Y, Cai J, Wei S, Gao R, Qin Q (2013b) Identification and characterization of a tumor necrosis factor receptor like protein encoded by Singapore grouper iridovirus. Virus Res 178:340-348

Hudziak RM, Summerton J, Weller DD, Iversen PL (2000) Antiproliferative effects of steric blocking phosphorodiamidate morpholino antisense agents directed against c-myc. Antisense Nucleic Acid Drug Dev 10:163-176

Jancovich JK, Bremont M, Touchman JW, Jacobs BL (2010) Evidence for multiple recent host species shifts among the ranaviruses (Family Iridoviridae). J. Virol. 84:2636-2647

Jancovich JK, Jacobs BL (2011) Innate immune evasion mediated by the Ambystoma tigrinum virus eukaryotic translation initiation factor 2 alpha homologue. J Virol 85:5061-5069

Jancovich JK, Mao J, Chinchar VG, Wyatt C, Case ST, Kumar S, Valente G, Subramanian S, Davidson EW, Collins JP, Jacobs BL (2003) Genomic sequence of a ranavirus (family Iridoviridae) associated with salamander mortalities in North America. Virology 316:90-103

Jancovich JK, Chinchar VG, Hyatt A, Miyazaki T, Williams T, Zhang QY (2012) Family Iridoviridae. In: King AMQ, Adams MJ, Carstens EB, Lefkowitz EJ (eds) Virus taxonomy: classification and nomenclature of viruses. Ninth report of the International Committee on Taxonomy of Viruses. Elsevier, Amsterdam, pp 193-210

Jancovich JK, Steckler N, Waltzek TB (2015) Ranavirus taxonomy and phylogeny. In: Gray MJ, Chinchar VG (eds) Ranaviruses: lethal pathogens of ectothermic vertebrates. Springer, New York

Jia KT, Wu YY, Liu ZY, Mi S, Zheng YW, He J, Weng SP, Li SC, He JG, Guo CJ (2013) Mandarin fish caveolin 1 interaction with major capsid protein of infectious spleen and kidney necrosis virus and its role in early stages of infection. J Virol 87:3027-3038

Johnston JB, McFadden G (2003) Poxvirus immunomodulatory strategies: current perspectives. J Virol 77:6093-6100

Johnston JB, McFadden G (2004) Technical knockout: understanding poxvirus pathogenesis by selectively deleting viral immunomodulatory genes. Cell Microbiol 6:695-705

Johnston JB, Barrett JW, Nazarian SH, Goodwin M, Ricciuto D, Wang G, McFadden G (2005) A poxvirus-encoded pyrin domain protein interacts with ASC-1 to inhibit host inflammatory and apoptotic responses to infection. Immunity 23:587-598

Kato A, Hirohata Y, Arii J, Kawaguchi Y (2014) Phosphorylation of herpes simplex virus 1 dUTPase up-regulated viral dUTPase activity to compensate for low cellular dUTPase activity for efficient viral replication. J Virol 88:7776-7785

Kaur K, Rohozinski J, Goorha R (1995) Identification and characterization of the frog virus 3 DNA methyltransferase gene. J Gen Virol 76(pt 8):1937-1943

Ke F, Zhao L, Zhang QY (2009) Cloning, expression and subcellular distribution of a Rana grylio virus late gene encoding ERV1 homologue. Mol Biol Report 36:1651-1659

Kim YS, Ke F, Lei XY, Zhu R, Zhang QY (2010) Viral envelope protein 53R gene highly specific silencing and iridovirus resistance in fish cells by AmiRNA. PLoS One 5:e10308

Koonin EV, Yutin N (2010) Origin and evolution of eukaryotic large nucleo-cytoplasmic DNA viruses. Intervirology 53:284-292 
Krug A, Towarowski A, Britsch S, Rothenfusser S, Hornung V, Bals R, Giese T, Engelmann H, Endres S, Krieg AM, Hartmann G (2001) Toll-like receptor expression reveals CpG DNA as a unique microbial stimulus for plasmacytoid dendritic cells which synergizes with CD40 ligand to induce high amounts of IL-12. Eur J Immunol 31:3026-3037

Krug A, Luker GD, Barchet W, Leib DA, Akira S, Colonna M (2004) Herpes simplex virus type 1 activates murine natural interferon-producing cells through toll-like receptor 9. Blood 103:1433-1437

Langelier Y, Bergeron S, Chabaud S, Lippens J, Guilbault C, Sasseville AM, Denis S, Mosser DD, Massie B (2002) The R1 subunit of herpes simplex virus ribonucleotide reductase protects cells against apoptosis at, or upstream of, caspase-8 activation. J Gen Virol 83:2779-2789

Langland JO, Jacobs BL (2002) The role of the PKR-inhibitory genes, E3L and K3L, in determining vaccinia virus host range. Virology 299:133-141

Langland JO, Cameron JM, Heck MC, Jancovich JK, Jacobs BL (2006) Inhibition of PKR by RNA and DNA viruses. Virus Res 119:100-110

Lei XY, Ou T, Zhang QY (2012a) Rana grylio virus (RGV) 50L is associated with viral matrix and exhibited two distribution patterns. PLoS One 7:e43033

Lei XY, Ou T, Zhu RL, Zhang QY (2012b) Sequencing and analysis of the complete genome of Rana grylio virus (RGV). Arch Virol 157:1559-1564

Lembo D, Brune W (2009) Tinkering with a viral ribonucleotide reductase. Trends Biochem Sci 34:25-32

Lewis T, Zsak L, Burrage TG, Lu Z, Kutish GF, Neilan JG, Rock DL (2000) An African swine fever virus ERV1-ALR homologue, 9GL, affects virion maturation and viral growth in macrophages and viral virulence in swine. J Virol 74:1275-1285

Lin PW, Huang YJ, John JA, Chang YN, Yuan CH, Chen WY, Yeh CH, Shen ST, Lin FP, Tsui WH, Chang CY (2008) Iridovirus Bcl-2 protein inhibits apoptosis in the early stage of viral infection. Apoptosis 13:165-176

Ma J, Zeng L, Zhou Y, Fiang N, Zhang H, Fan Y, Meng Y, Xu J (2014) Ultrastructural morphogenesis of an amphibian iridovirus isolated from Chinese giant salamander (Andrias davidianus). J Comp Pathol 150:325-331

Majji S, Thodima V, Sample R, Whitley D, Deng Y, Mao J, Chinchar VG (2009) Transcriptome analysis of Frog virus 3, the type species of the genus Ranavirus, family Iridoviridae. Virology 391:293-303

Maniero GD, Morales H, Gantress J, Robert J (2006) Generation of a long-lasting, protective, and neutralizing antibody response to the ranavirus FV3 by the frog Xenopus. Dev Comp Immunol 30:649-657

Mavian C, Lopez-Bueno A, Balseiro A, Casais R, Alcami A, Alejo A (2012) The genome sequence of the emerging common midwife toad virus identifies an evolutionary intermediate within ranaviruses. J Virol 86:3617-3625

Moody NJG, Owens L (1994) Experimental demonstration of pathogenicity of a frog virus, Bohle iridovirus, for a fish species, barramundi Lates Calcarifer. Dis Aquat Organ 18:95-102

Morales HD, Robert J (2007) Characterization of primary and memory CD8 T-cell responses against ranavirus (FV3) in Xenopus laevis. J Virol 81:2240-2248

Morales HD, Abramowitz L, Gertz J, Sowa J, Vogel A, Robert J (2010) Innate immune responses and permissiveness to ranavirus infection of peritoneal leukocytes in the frog Xenopus laevis. J Virol 84:4912-4922

Morrison EA, Garner S, Echaubard P, Lesbarreres D, Kyle CJ, Brunetti CR (2014) Complete genome analysis of a frog virus 3 (FV3) isolate and sequence comparison with isolates of differing levels of virulence. Virol J 11:46

Murti KG, Goorha R, Chen M (1985) Interaction of frog virus 3 with the cytoskeleton. Curr Top Microbiol Immunol 116:107-131

Murti KG, Goorha R, Klymkowsky MW (1988) A functional role for intermediate filaments in the formation of frog virus 3 assembly sites. Virology 162:264-269 
Naegele RF, Granoff A (1971) Viruses and renal cancinoma of Rana pipiens. XI. Isolation of Frog virus 3 temperature-sensitive mutants; complementation and genetic recombination. Virology 44:286-295

Nichols RJ, Stanitsa E, Unger B, Traktman P (2008) The vaccinia virus gene I2L encodes a membrane protein with an essential role in virion entry. J Virol 82:10247-10261

Oliveros M, Garcia-Escudero R, Alejo A, Vinuela E, Salas ML, Salas J (1999) African swine fever virus dUTPase is a highly specific enzyme required for efficient replication in swine macrophages. J Virol 73:8934-8943

Ou-yang Z, Wang P, Huang X, Cai J, Huang Y, Wei S, Ji H, Wei J, Zhou Y, Qin Q (2012) Immunogenicity and protective effects of inactivated Singapore grouper iridovirus (SGIV) vaccines in orange-spotted grouper, Epinephelus coioides. Dev Comp Immunol 38:254-261

Pallister J, Goldie S, Coupar B, Shiell B, Michalski WP, Siddon N, Hyatt A (2007) Bohle iridovirus as a vector for heterologous gene expression. J Virol Methods 146:419-423

Pavelin J, Reynolds N, Chiweshe S, Wu G, Tiribassi R, Grey F (2013) Systematic microRNA analysis identifies ATP6V0C as an essential host factor for human cytomegalovirus replication. PLoS Pathog 9:e1003820

Pham PH, Lai YS, Lee FF, Bols NC, Chiou PP (2012) Differential viral propagation and induction of apoptosis by grouper iridovirus (GIV) in cell lines from three non-host species. Virus Res 167:16-25

Purifoy D, Naegele RF, Granoff A (1973) Viruses and renal carcinoma of Rana pipiens. XIV. Temperature-sensitive mutants of frog virus 3 with defective encapsidation. Virology 54:525-535

Raghow R, Granoff A (1979) Macromolecular synthesis in cells infected by frog virus 3. X. Inhibition of cellular protein synthesis by heat-inactivated virus. Virology 98:319-327

Reading PC, Moore JB, Smith GL (2003) Steroid hormone synthesis by vaccinia virus suppresses the inflammatory response to infection. J Exp Med 197:1269-1278

Ring BA, Ferreira Lacerda A, Drummond DJ, Wangen C, Eaton HE, Brunetti CR (2013) Frog virus 3 open reading frame 97R localizes to the endoplasmic reticulum and induces nuclear invaginations. J Virol 87:9199-9207

Robert J (2010) Emerging ranaviral infectious diseases and amphibian decline. Diversity 2:314-330

Robert J, Morales H, Buck W, Cohen N, Marr S, Gantress J (2005) Adaptive immunity and histopathology in frog virus 3-infected Xenopus. Virology 332:667-675

Rothenburg S, Chinchar VG, Dever TE (2011) Characterization of a ranavirus inhibitor of the antiviral protein kinase PKR. BMC Microbiol 11:56

Rouiller I, Brookes SM, Hyatt AD, Windsor M, Wileman T (1998) African swine fever virus is wrapped by the endoplasmic reticulum. J Virol 72:2373-2387

Sample R (2010) Elucidation of Frog Virus 3 gene function and pathways of virion formation. Ph.D. dissertation, University of Mississippi Medical Center, Jackson, MS

Sample R, Bryan L, Long S, Majji S, Hoskins G, Sinning A, Olivier J, Chinchar VG (2007) Inhibition of iridovirus protein synthesis and virus replication by antisense morpholino oligonucleotides targeted to the major capsid protein, the $18 \mathrm{kDa}$ immediate-early protein, and a viral homolog of RNA polymerase II. Virology 358:311-320

Seet BT, Johnston JB, Brunetti CR, Barrett JW, Everett H, Cameron C, Sypula J, Nazarian SH, Lucas A, McFadden G (2003) Poxviruses and immune evasion. Annu Rev Immunol 21:377-423

Song W, Lin Q, Joshi SB, Lim TK, Hew CL (2006) Proteomic studies of the Singapore grouper iridovirus. Mol Cell Proteomics 5:256-264

Summerton JE (2007) Morpholino, siRNA, and S-DNA compared: impact of structure and mechanism of action on off-target effects and sequence specificity. Curr Top Med Chem 7:651-660

Summerton J, Weller D (1997) Morpholino antisense oligomers: design, preparation, and properties. Antisense Nucleic Acid Drug Dev 7:187-195

Sun W, Huang Y, Zhao Z, Gui J, Zhang Q (2006) Characterization of the Rana grylio virus 3betahydroxysteroid dehydrogenase and its novel role in suppressing virus-induced cytopathic effect. Biochem Biophys Res Commun 351:44-50 
Tan WG, Barkman TJ, Gregory Chinchar V, Essani K (2004) Comparative genomic analyses of frog virus 3, type species of the genus Ranavirus (family Iridoviridae). Virology 323:70-84

Tang X, Metzger D, Leeman S, Amar S (2006) LPS-induced TNF-alpha factor (LITAF)-deficient mice express reduced LPS-induced cytokine: evidence for LITAF-dependent LPS signaling pathways. Proc Natl Acad Sci U S A 103:13777-13782

Teng Y, Hou Z, Gong J, Liu H, Xie X, Zhang L, Chen X, Qin QW (2008) Whole-genome transcriptional profiles of a novel marine fish iridovirus, Singapore grouper iridovirus (SGIV) in virusinfected grouper spleen cell cultures and in orange-spotted grouper, Epinephulus coioides. Virology 377:39-48

Thorpe C, Hoober KL, Raje S, Glynn NM, Burnside J, Turi GK, Coppock DL (2002) Sulfhydryl oxidases: emerging catalysts of protein disulfide bond formation in eukaryotes. Arch Biochem Biophys 405:1-12

Tidona CA, Darai G (1997) The complete DNA sequence of lymphocystis disease virus. Virology 230:207-216

Tran BN, Chen L, Liu Y, Wu J, Velazquez-Campoy A, Sivaraman J, Hew CL (2011) Novel histone H3 binding protein ORF158L from the Singapore grouper iridovirus. J Virol 85:9159-9166

Tulman ER, Delhon GA, Ku BK, Rock DL (2009) African swine fever virus. Curr Top Microbiol Immunol 328:43-87

Tweedell K, Granoff A (1968) Viruses and renal carcinoma of Rana pipiens. V. Effect of frog virus 3 on developing frog embryos and larvae. J Natl Cancer Inst 40:407-410

Verrier ER, Langevin C, Benmansour A, Boudinot P (2011) Early antiviral response and virusinduced genes in fish. Dev Comp Immunol 35:1204-1214

Wan QJ, Gong J, Huang XH, Huang YH, Zhou S, Ou-Yang ZL, Cao JH, Ye LL, Qin QW (2010) Identification and characterization of a novel capsid protein encoded by Singapore grouper iridovirus ORF038L. Arch Virol 155:351-359

Wang F, Bi X, Chen LM, Hew C-L (2008a) ORF018R, a highly abundant virion protein from Singapore grouper iridovirus, is involved in serine/threonine phosphorylation and virion assembly. J Gen Virol 89:1169-1178

Wang Q, Luo Y, Xie J, Dong C, Weng S, Ai H, Lu L, Yang X, Yu X, He J (2008b) Identification of two novel membrane proteins from the Tiger frog virus (TFV). Virus Res 136:35-42

Wang Z-L, Xu X-P, He B-L, Weng S-P, Xiao J, Wang L, Lin T, Liu X, Wang Q, Yu X-Q, He J-G (2008c) ISKNV ORF48R functions as a new viral vascular endothelial growth factor. J Virol 82:4371-4383

Wang S, Huang X, Huang Y, Hao X, Xu H, Cai M, Wang H, Qin Q (2014) Entry of a novel marine DNA virus (Singapore grouper iridovirus, SGIV) into host cells occurs via clathrin-mediated endocytosis and macropinocytosis in a pH-dependent manner. J Virol 01744-14 88: $13047-13063$

Whitley DJS (2011) Determinations of ranavirus gene function using an antisense morpholinomediated approach. University of Mississippi Medical Center, Jackson, MS. Ph.D. dissertation

Whitley DS, Yu K, Sample RC, Sinning A, Henegar J, Norcross E, Chinchar VG (2010) Frog virus 3 ORF 53R, a putative myristoylated membrane protein, is essential for virus replication in vitro. Virology 405:448-456

Whitley DS, Sample RC, Sinning AR, Henegar J, Chinchar VG (2011) Antisense approaches for elucidating ranavirus gene function in an infected fish cell line. Dev Comp Immunol 35:937-948

Williams T (1996) The iridoviruses. Adv Virus Res 46:345-412

Williams T, Barbosa-Solomieu V, Chinchar VG (2005) A decade of advances in iridovirus research. Adv Virus Res 65:173-248

Willis DB, Granoff A (1978) Macromolecular synthesis in cells infected by frog virus 3. IX. Two temporal classes of early viral RNA. Virology 86:443-453

Willis DB, Granoff A (1980) Frog virus 3 DNA is heavily methylated at CpG sequences. Virology 107:250-257

Willis DB, Granoff A (1985) Transactivation of an immediate-early frog virus 3 promoter by a virion protein. J Virol 56:495-501 
Willis DB, Thompson JP (1986) The Iridovirus frog virus 3: a model for trans-acting proteins. Microbiol Sci 3:59-63

Willis DB, Goorha R, Granoff A (1984) DNA methyltransferase induced by frog virus 3. J Virol 49:86-91

Willis DB, Goorha R, Chinchar VG (1985) Macromolecular synthesis in cells infected by frog virus 3. Curr Top Microbiol Immunol 116:77-106

Willis DB, Essani K, Goorha R, Thompson JP, Granoff A (1990) Transcription of a methylated DNA virus, nucleic acid methylation. Alan R. Liss, Inc., New York, pp 139-151

Wilson WH, Van Etten JL, Allen MJ (2009) The Phycodnaviridae: the story of how tiny giants rule the world. Curr Top Microbiol Immunol 328:1-42

Xia L, Cao J, Huang X, Qin Q (2009) Characterization of Singapore grouper iridovirus (SGIV) ORF 086R, a putative homolog of ICP18 involved in cell growth control and virus replication. Arch. Virol. 154:1409-1416

Xia L, Liang H, Huang Y, Ou-Yang Z, Qin Q (2010) Identification and characterization of Singapore grouper iridovirus (SGIV) ORF162L, an immediate-early gene involved in cell growth control and viral replication. Virus Res 147:30-39

Xie J, Lu L, Deng M, Weng S, Zhu J, Wu Y, Gan L, Chan SM, He J (2005) Inhibition of reporter gene and Iridovirus-tiger frog virus in fish cell by RNA interference. Virology 338:43-52

Xu X, Weng S, Lin T, Tang J, Huang L, Wang J, Yu X, Lu L, Huang Z, He J (2010) VP23R of infectious spleen and kidney necrosis virus mediates formation of virus-mock basement membrane to provide attaching sites for lymphatic endothelial cells. J Virol 84:11866-11875

Yan X, Yu Z, Zhang P, Battisti AJ, Holdaway HA, Chipman PR, Bajaj C, Bergoin M, Rossmann MG, Baker TS (2009) The capsid proteins of a large, icosahedral dsDNA virus. J Mol Biol 385:1287-1299

Yan Y, Cui H, Jiang S, Huang Y, Huang X, Wei S, Xu W, Qin Q (2011) Identification of a novel marine fish virus, Singapore grouper iridovirus-encoded microRNAs expressed in grouper cells by Solexa sequencing. PLoS One 6:e19148

Yan Y, Cui H, Guo C, Li J, Huang X, Wei J, Qin Q (2013) An insulin-like growth factor homologue of Singapore grouper iridovirus modulates cell proliferation, apoptosis and enhances viral replication. J Gen Virol 94:2759-2770

Yan Y, Cui H, Guo C, Wei J, Huang Y, Li L, Qin Q (2014) Singapore grouper iridovirus-encoded semaphorin homolog (SGIV-sema) contributes to viral replication, cytoskeleton reorganization and inhibition of cellular immune responses. J Gen Virol 95:1144-1155

Zhang QY, Gui JF (2012) Atlas of aquatic viruses and viral diseases. Science Press, Beijing

Zhao Z, Ke F, Gui J, Zhang Q (2007) Characterization of an early gene encoding for dUTPase in Rana grylio virus. Virus Res 123:128-137

Zhao Z, Ke F, Huang YH, Zhao JG, Gui JF, Zhang QY (2008) Identification and characterization of a novel envelope protein in Rana grylio virus. J Gen Virol 89:1866-1872

Zhou S, Wan Q, Huang Y, Huang X, Cao J, Ye L, Lim TK, Lin Q, Qin Q (2011) Proteomic analysis of Singapore grouper iridovirus envelope proteins and characterization of a novel envelope protein VP088. Proteomics 11:2236-2248 


\title{
Ranavirus Host Immunity and Immune Evasion
}

\author{
Leon Grayfer, Eva-Stina Edholm, Francisco De Jesús Andino, \\ V. Gregory Chinchar, and Jacques Robert
}

\section{Introduction}

Infections of ectothermic vertebrates by members of the genus Ranavirus (RV; family Iridoviridae) and the resulting disease outbreaks and die-offs among wild and farmed populations have escalated at alarming rates recently and raised considerable concerns. While it is apparent that individual teleost, amphibian, and reptile species vary in their susceptibility to these pathogens, the immune and viral determinants of ranaviral diseases are at present unclear. In fact, with the rapid rise in both the prevalence of ranavirus infections and the remarkable capacity of these viruses to infect new hosts, ranaviruses such as Frog Virus 3 (FV3) are now considered to be a potential global threat to poikilothermic populations (Gray and Miller 2013). There is a pressing need to determine whether the susceptibility of a given ectothermic species reflects its inability to mount a protective antiviral immune response or the capacity of the ranavirus to overcome otherwise intact immune barriers. Indeed, ranaviruses appear to possess an array of immune evasion and host modulation mechanisms. Thus, a more thorough examination of the ranavirushost immune interface at the molecular and cellular levels is necessary in order to devise potential preventative measures against these viral agents.

Compared to mammals, ectothermic vertebrates possess a complex immune system, but they mount relatively less effective adaptive immune responses. Ectotherms display poorer T lymphocyte expansion, fewer antibody isoforms, and

\footnotetext{
L. Grayfer • E.-S. Edholm • F. De Jesús Andino • J. Robert $(\bowtie)$

Department of Microbiology and Immunology, University of Rochester Medical Center,

601 Elmwood Ave, Box 672, Rochester, NY 14642, USA

e-mail: Jacques_Robert@urmc.rochester.edu

V.G. Chinchar

Department of Microbiology, University of Mississippi Medical Center,

2500 North State Street, Jackson, MS 39216, USA
} 
generally a less developed immunological memory response than mammals (Robert and Ohta 2009). Thus, these organisms may rely more heavily on innate immune responses to facilitate clearance of pathogens such as ranaviruses. Innate antiviral immune defenses in ectothermic vertebrates are distinct from those described in mammals, although the exact contribution and efficacies of this immune response need to be elucidated in the context of ranavirus infections.

This chapter summarizes recent advances in our understanding of the contributions of innate and adaptive immune responses to the elimination and/or progression of ranaviral infections in poikilotherms as well as an overview of the strategies of these pathogens for evading host immune barriers.

\section{Innate Immune Responses to Ranavirus Infections}

\subsection{Antimicrobial Peptide Responses to Ranaviral Infection}

Antimicrobial peptides are an important element of anuran innate immunity that provides protection to skin and mucosal surfaces against a variety of pathogens. These small molecules are synthesized and stored in the dermal granular glands and secreted into mucus in response to stress or injury (Rollins-Smith 2009; RollinsSmith et al. 2005). Antimicrobial peptides are also involved in defenses against ranaviruses. Esculentin-2P (E2P) and Ranatuerin-2P (R2P), two antimicrobial peptides isolated from Rana pipiens, are capable of inactivating both FV3 and channel catfish virus $(\mathrm{CCV})$ within minutes and at temperatures as low as $0^{\circ} \mathrm{C}$. This suggests that direct interaction of these molecules with the viruses rather than inhibition of viral replication is responsible for the drop in infectivity (Chinchar et al. 2001). The ability of antimicrobial peptides to function across a broad range of temperatures presumably reflects the ectothermic nature of the host. Notably, $50 \mu \mathrm{M}$ of E2P or $\mathrm{R} 2 \mathrm{P}$ was sufficient for $99 \%$ inactivation of $\mathrm{CCV}$, whereas a ten times greater concentration of either peptide was necessary to achieve $90 \%$ inactivation of FV3 (Chinchar et al. 2001). It was postulated that the greater resistance of FV3 to inactivation reflected the difficulty of antimicrobial peptides to target the inner lipid membrane beneath the FV3 capsid. Presumably, this inner membrane requires disruption in order for viral inactivation to occur. Other antimicrobial peptides, including Ranatuerin-2YJ, Dybowskin-YJb, Dybowskin-YJa, Temperin-YJa, and Temperin-YJb have been identified and cloned from the skin of Rana dybowskii infected with Rana grylio virus (RGV) (Yang et al. 2012). Interestingly, all of these peptides conferred concentration-dependent inhibition of RGV plaque formation, while viral clearance coincided with increased expression of genes encoding these molecules (Yang et al. 2012). 


\subsection{Innate and Inflammatory Immune Responses}

Ranaviral infections are widely associated with prominent host inflammatory responses. Indeed, akin to mammalian viral infections, ranavirus-elicited inflammatory responses represent a double-edged sword as they are both critical for viral clearance, but may also exacerbate ranavirus-mediated disease and adversely affect host survival. As it stands, there is substantial documentation of innate immune responses and associated inflammation to ranavirus infections across a range of poikilothermic host species (Carey et al. 1999; Chen and Robert 2011; Grayfer et al. 2014; Jancovich and Jacobs 2011; Morales et al. 2010).

\subsubsection{Anuran Amphibians}

Our research group has adopted and optimized the infection of Xenopus laevis by FV3 as a model for ranavirus-ectothermic vertebrate (particularly anuran) antiviral immunity. This model pairs FV3, the best-described ranavirus at the molecular level, with Xenopus laevis, which possesses the most-characterized amphibian immune system. Typically, our experimental approach involves the intraperitoneal (i.p.) injection of $X$. laevis adults or tadpoles with FV3 followed by an assessment of the progress of infection, viral replication, and the host immune response. Although similar immune responses may be obtained in Xenopus by using i.p. injection or water bath exposure (Robert et al. 2011), the former tends to be more convenient and consistent for immunological studies. By this approach, we have been able to delineate the sequential progression of the innate and adaptive immune responses of adult $X$. laevis throughout the course of FV3 infection (Morales et al. 2010). In X. laevis adults, histochemical and flow cytometric analyses revealed that activated mononuclear and polymorphonuclear phagocytes are recruited to, and heavily represented within peritoneal exudates as early as 1 day following i.p. infection (Morales et al. 2010). We subsequently observed the peritoneal recruitment and accumulation of natural killer (NK) cells by 3 days after infection, whereas lymphocyte recruitment, including the increased presence of T cells, was not observed until 6 days post-FV3 challenge (Morales et al. 2010). Notably, the rapid accumulation of peritoneal leukocytes was concomitant with substantially elevated inflammatory gene expression. Among the hallmark inflammatory genes examined, we observed significant increases in the expression of $X$. laevis tumor necrosis factor-alpha (TNF- $\alpha$ ) as early as 1 day postinfection and persisting to 3 days after FV3 exposure (Morales et al. 2010). Expression of the interleukin-1-beta (IL-1 $\beta$ ) gene, encoding an early proinflammatory cytokine produced by macrophages, was elevated at days 1 through 6 of FV3 challenge, while the anti-inflammatory arginase-1 (Arg-1), a marker of alternatively polarized (M2) macrophages (Joerink et al. 2006b, c), was elevated at day 1 post-viral challenge and subsequently decreased (Morales et al. 2010). Together these findings show an effective and well-coordinated antiviral immune response, 
with sequential recruitment of innate and adaptive immune cell effectors and corresponding immune gene activation. The elevated level of Arg-1 gene expression at 1 day postinfection may be reflective of resident, rather than recruited inflammatory myeloid populations. Indeed, subsequent to FV3 peritoneal inoculation, we have consistently observed elevated mRNA transcripts for macrophage and granulocyte colony-stimulating factor receptors (M-CSFR and G-CSFR, respectively), indicative of accumulating myeloid infiltrates (L. Grayfer and J. Robert, University of Rochester, unpublished data). Notably, the elevated expression of M-CSFR (and G-CSFR) within peritoneal leukocytes (PLs) is typically accompanied by significantly increased expression of the M1 macrophage marker, inducible nitric oxide synthase (iNOS), which catalyzes the production of the antimicrobial nitric oxide by inflammatory macrophages (L. Grayfer, F. De Jesús Andino and J. Robert, University of Rochester, unpublished data). This supports the observation of decreased Arg-1 expression with the onset of an inflammatory state within the peritoneum and indicates that Arg-1 and iNOS functions are opposite across multiple groups of vertebrates (Joerink et al. 2006a, b, c; Wiegertjes and Forlenza 2010).

It is important to emphasize that amphibian susceptibility to ranaviruses varies considerably among species, their respective stages of development, and even between different populations of the same species (Miller et al. 2011). These differences likely result from multiple complex determinants including host and ranavirus genetic variability as well as the respective host immune status. Extensive immunological studies of Xenopus suggest that tadpoles possess a distinct immune system from that of adults. The larval system is typically more immature, particularly with regard to adaptive immunity (e.g., poor $\mathrm{T}$ cell and antibody responses). In this regard, it is altogether not surprising that tadpoles are typically unable to fully control ranavirus infections and succumb to these pathogens (Bayley et al. 2013; Grayfer et al. 2014; Hoverman et al. 2010; Landsberg et al. 2013; Reeve et al. 2013). However, it is clear that in some amphibian species, adult frogs also die from ranavirus infections (Sutton et al. 2014). Indeed, several reports indicate that compared to larvae of given amphibian species, metamorphic (Brunner et al. 2004; Haislip et al. 2011; Reeve et al. 2013) and adult (Duffus et al. 2013) animals may be more susceptible to ranaviruses. Given the rapid development of tadpoles and their drastic metamorphic remodeling, species-specific immune development pathways may explain differences in ranavirus susceptibility. Extensive immune remodeling may render metamorphs more susceptible than larvae at critical developmental stages. Moreover, the fact that ranavirus-infected Xenopus tadpoles bear lower viral loads than adults, yet succumb more readily to FV3 infection (Grayfer et al. 2014) suggests that it may be more difficult to detect this virus in tadpoles than adults or that lower viral loads trigger markedly greater disease in tadpoles.

To delineate possible inefficiencies in innate immune responses of anuran tadpoles that may account for ranavirus susceptibility, we performed an extensive comparison of immune gene expression patterns between FV3-infected X. laevis tadpoles and adults (De Jesús Andino et al. 2012). In contrast to infected adult frogs, tadpoles exhibited poor and considerably delayed anti-FV3 inflammatory gene responses (De Jesús Andino et al. 2012). TNF $\alpha$, IL-1 $\beta$, and IFN $\gamma$ gene expression 
in tadpole PLs, splenocytes, and kidneys did not significantly increase until 6 days post FV3 challenge, which is in contrast with the robust and quick ( 1 dpi) upregulation of these genes in infected adults (De Jesús Andino et al. 2012). Notably, stimulation of tadpoles with heat-killed Escherichia coli readily elicits rapid induction of the above genes within $24 \mathrm{~h}$, suggesting that the immune delays are FV3 specific (De Jesús Andino et al. 2012). These inefficiencies in the tadpole innate immune response to FV3 may reflect multiple nonexclusive issues including viral immune evasion, defect(s) in the tadpole pathogen sentinel receptor system, or physiological treadoffs to forego energetically costly inflammatory responses in favor of growth and development. Thus, these modest and delayed immune responses are likely contributing factors for the characteristically higher susceptibility of anuran tadpoles to FV3 infection and severe disease.

\subsubsection{Urodel Amphibians}

Consistent with the notion that hosts mount broad inflammatory responses to ranaviruses, a comprehensive microarray analysis of axolotls (Ambystoma mexicanum) infected with the Ambystoma tigrinum virus (ATV) revealed the upregulation of numerous hallmark pro-inflammatory and innate immune gene components in the spleens and lungs of these animals (Cotter et al. 2008). These genes included (but were not limited to) phagocytic receptors and intracellular components, cytokine signaling molecules, complement components, NADPH oxidase subunits (myeloid enzyme catalyzing the reactive oxygen antimicrobial response), and myloperoxidase (granulocyte enzyme catalyzing the production of hydrogen peroxide) (Cotter et al. 2008). In contrast to what has been observed in X. laevis infected with FV3 (Morales et al. 2010; Morales and Robert 2007), no lymphocyte proliferation genes were upregulated in response to ATV infections (Cotter et al. 2008). This lack of an efficient adaptive response in this species may explain why ATV is so lethal to urodels. Alternatively these observations may reflect a different infection strategy by ATV.

\subsubsection{Teleost Fish}

There is a substantial literature documenting innate immune and associated inflammatory responses to ranavirus infections in bony fish. Infection of the Epithilioma papulosum cyprini (EPC) teleost cell line with four distinct ranaviruses, FV3, European catfish virus (ECV), Doctor fish virus (DFV), and Epizootic haematopoietic necrosis virus (EHNV), resulted in distinct inflammatory gene expression profiles (Holopainen et al. 2012). Specifically, EHNV and FV3 elicited expression of the hallmark pro-inflammatory genes, TNF $\alpha$ and IL-1 $\beta$, whereas ECV and DFV induced the transient expression of a generally immunosuppressive gene, transforming growth factor-beta (TGF $\beta$ ) (Holopainen et al. 2012). Interestingly, all four viruses elicited expression of apoptotic components and $\beta 2$-microglobulin, which is critical for surface MHC class I expression and cytotoxic T cell function, suggesting 
that at least with respect to FV3 infection of teleosts (as compared to axolotls), the adaptive immune response may be elicited by ranaviral infections.

A recent microarray study examined the transcriptional response of fathead minnow (FHM) cells following infection with either wild type (wt) FV3 or a knockout (KO) mutant lacking the truncated vIF- $2 \alpha$ gene. Infection with wt FV3 resulted in the upregulation of numerous immune related genes by $8 \mathrm{~h}$ p.i., including IL-8, IFN, IFN regulatory factor (IRF) $-1,-2$, and -3 , IL-1 $\beta$, etc. For the most part, similar genes were upregulated in cells infected with the KO mutant, but the magnitude of the induction was generally lower (Cheng et al. 2014).

\subsection{Determinants of Ranavirus-Induced Pathogenicity and Mortality}

An appropriate, timely resolution of inflammation is just as important as the induction and progression of this response, because a prolonged inflammatory response increases the risk of tissue damage and host death (Fullerton et al. 2013). Although sparse, there is evidence suggesting that ranavirus infections may exacerbate inflammatory responses, accounting for some of the observed ranavirus pathology. For example, in 1997 a novel iridovirus was isolated in Saskatchewan (Canada) from larval tiger salamanders (Bollinger et al. 1999). These animals suffered from exacerbated inflammation, necrosis, and characteristic ranavirus-induced cytoplasmic inclusions within splenic, renal, lymphoid, and hematopoietic tissues (Bollinger et al. 1999). Similarly, whole populations of ranavirus-infected greenstriped tree dragons (Japalura splendida) exhibited systemic hemorrhaging, necrosis, granulomatous, and necrotic inflammation, as well as severe renal pathology, hyperanemia, and extensive hepatic damage (Behncke et al. 2013), culminating in mass mortality. Ranavirus infection within pythons suggests that inflammation may be a determinant of ranaviral pathology (Hyatt et al. 2002). Mortality of largemouth bass infected intraperitoneally with largemouth bass virus (LMBV) is believed to result from virally induced inflammation and associated necrosis (Zilberg et al. 2000). Consistent with these inflammatory symptoms, juvenile bass inoculated with LMBV exhibited corkscrew swimming and distended abdomens (Zilberg et al. 2000). Notably, the deeper tissues of infected fish were unaffected, bringing into question whether virus-induced damage was due to target cell accessibility or the limitations of LMBV cell tropism. The latter suggests that inflammation and necrotic damage resulting in mortality may be the result of primary injuries at the initial sites of infection. Indeed, the above observations are reminiscent of earlier studies of FV3 infections in rodents (Gut et al. 1981; Kirn et al. 1980, 1982), in which, despite the inability of FV3 to replicate at $37^{\circ} \mathrm{C}$ (Aubertin et al. 1973), the initial viral inoculum was responsible for extensive inflammation, necrosis, and liver damage. 
Our recent findings in Xenopus support the induction of a pro-inflammatory response by FV3 (Grayfer et al. 2014). Mindful of the idea that $X$. laevis adults presumably mount effective anti-ranaviral responses leading to viral clearance, we were intrigued to find that (at least during acute infections) adults possessed significantly greater FV3 loads ( 1 to 2 orders of magnitude) than tadpoles, which are typically more susceptible to FV3 infections (Grayfer et al. 2014). Also, a possible influence of temperature on viral loads was observed in wood frog tadpoles, where these animals succumbed to infection quicker at $25^{\circ} \mathrm{C}$ but at higher viral loads than those maintained at $15^{\circ} \mathrm{C}$ (J. Chaney and M. Gray, University of Tennessee, unpublished data). These results suggest that FV3 virulence is not strictly dependent on the magnitude of viral replication. Additionally, immunocompetent tadpoles may be more vulnerable to ranaviral virulence factors and other environmental parameters than adults. In support of this hypothesis, we observed that although tadpoles prestimulated with recombinant $X$. laevis type I interferon ( $\mathrm{r} X l \mathrm{IFN}$ ) possessed viral loads several logs lower than adults, they nonetheless succumbed to FV3 infection (Grayfer et al. 2014). Furthermore, despite lower FV3 loads, IFN-treated larvae experienced damage to multiple organs, including extensive loss of tissue architecture and cellular organization through necrosis and apoptosis, albeit without extensive leukocyte infiltration (Grayfer et al. 2014). Therefore, even at markedly reduced viral loads, ranaviruses may confer irreversible tissue damage in tadpoles relatively early in infection, resulting primarily from virus-mediated cytopathology rather than from viral replication. Indeed, as seen in rodent models of FV3, ranaviruses may trigger toxic and potentially lethal effects, irrespective of their capacity to replicate within their host cells (Gendrault et al. 1981). This notion has recently been substantiated with Grouper iridovirus (GIV). Replication-deficient UV-inactivated GIV induced apoptosis in two of the three infected cell lines (Pham et al. 2012). Similarly, heat- and UV-inactivated FV3 elicits FHM cell apoptosis and inhibits host RNA and protein synthesis (Chinchar et al. 2003; Raghow and Granoff 1979). Based on these findings, we hypothesize that inoculation of animals with sufficient inactivated virus will induce toxicity in the absence of virus replication. If this hypothesis holds true for other members of the genus and family, we may need to consider that these viruses are more pathogenic than previously thought.

\section{The Complex Roles of Macrophage-Lineage Cells in Ranaviral Disease}

\subsection{Inferences from Rodent Models of FV3 Infection}

The involvement of macrophage-lineage cells in ranavirus infections may be inferred from initial studies conducted 30 years ago using rodents as models of hepatitis (Gut et al. 1981; Kirn et al. 1980, 1982). These early studies revealed that Kupffer cells (liver macrophages) were the principal targets of FV3 infection and 
that their death was linked to the loss of hepatic clearance and culminated in severe hepatitis and mortality (Gut et al. 1981). These studies also implicated inflammation as a contributor to FV3-mediated pathology, including extensive leukotriene release by Kupffer cells (Hagmann et al. 1987). Inhibition of leukotriene synthesis within FV3-infected animals dramatically reduced virally elicited hepatic damage (Hagmann et al. 1987), suggesting that pathology was largely due to inflammatory responses.

Although FV3 is not a mammalian pathogen and, with the exception of expression of select early genes (Lopez et al. 1986) does not replicate at $37{ }^{\circ} \mathrm{C}$ (Aubertin et al. 1973), this work nonetheless supports the current hypothesis that, because of their high phagocytic and endocytic activity, macrophage-lineage cells are integral targets for ranavirus infections. In fact, the absence of replication at $37{ }^{\circ} \mathrm{C}$ may be viewed as an advantage for investigating the mechanisms of FV3 cell entry. In cultured rat Kupffer cells, viral particles appeared in phagocytic vacuoles and endocytic compartments promptly following FV3 infection (Gendrault et al. 1981). Moreover, a substantial proportion of FV3 virions that attached to cells displayed viral capsid-host membrane fusion and release of viral core contents into cell cytoplasm (Gendrault et al. 1981). This observation suggests that the underlying mechanisms governing ranavirus entry are universal and facilitate entry of cells from organisms as evolutionarily distant as mammals, fish, and amphibians. In line with this reasoning, it is likely that cells of the myeloid lineage serve as ranaviral targets precisely because of their high efficiency of ingestion of extracellular materials, facilitated by an array of endocytic/phagocytic surface receptors, several of which likely recognize and bind ranaviruses. This feature of vertebrate professional phagocytes may have been targeted as a ranaviral infection strategy and may explain why ranaviruses successfully cross host species boundaries. Furthermore, because ranaviruses cannot replicate at mammalian body temperatures, the above-described literature implies that that the pathological events seen in FV3-infected rodents are not the result of full virus replication. Instead, cell death is presumably triggered by preformed lytic factors encapsulated within FV3 virions or the expression of early viral gene products (Lopez et al. 1986). Similar to the mRNA present within adenovirus virions (Chung et al. 2003), FV3 early gene expression at nonpermissive temperatures may also result from the release of prepackaged virulence factor-encoding mRNAs rather than from de novo viral transcription. Indeed, FV3 infection of mammalian cells induces rapid cellular RNA, DNA, and protein synthesis arrest (Elharrar et al. 1973). Furthermore, factors solubilized from FV3 virions result in cellular toxicity and inhibit host macromolecular synthesis (Aubertin et al. 1973; Kirn et al. 1972)

\subsection{Amphibian Vectors of Ranaviral Dissemination and Persistence}

Increasing evidence from natural ranavirus infections of amphibians supports the idea that macrophages are important not only for antiviral defense, but also to ranavirus infection strategies. We utilized FV3 infection of X. laevis as a platform for 
the study of the ranavirus-host immune interface, with converging lines of evidence from our past and current work confirming FV3-X. laevis macrophage interactions. We have demonstrated that FV3 persists within amphibian hosts for several months following the resolution of clinically apparent disease (Robert et al. 2007). In addition, FV3 DNA could be detected in healthy animals that were not infected in the laboratory. This suggests that FV3 adopts some form of quiescence as a means of maintenance within immuno-competent hosts. Notably, FV3 effectively infects frog peritoneal leukocytes both in vitro and in vivo, persists within these cells and undergoes active viral transcription for up to 12 days subsequent to infection (Robert et al. 2007). Since peritoneal leukocytes are comprised predominantly of macrophage-lineage cells, our findings not only corroborate the ranavirusmacrophage tropism, but also suggest that these terminally differentiated, long-lived populations are ideal vectors for viral dissemination, or serve as "within host" reservoirs.

The above hypothesis has been substantiated by our subsequent transmission electron microscopy analysis of FV3-infected $X$. laevis peritoneal leukocytes in which we detected icosahedral virus particles in peritoneal leukocytes bearing macrophage morphology (Morales et al. 2010). These FV3-infected cells exhibited small numbers of intracellular viral particles, implying that FV3 may employ mononuclear phagocytes as a reservoir for dissemination. FV3-macrophage interaction is reminiscent of the HIV-macrophage relationship in which viral particles accumulate within the myeloid cells as a mechanism of dissemination (Coiras et al. 2009; Goodenow et al. 2003; Gousset et al. 2008; Groot et al. 2008). Interestingly, several of these FV3-infected peritoneal macrophages not only contained cytoplasmic virions, they also shed virions into the extracellular milieu (Morales et al. 2010), confirming that these cells likely function as both reservoirs and vectors of viral dissemination within their hosts.

In general, i.p. infection of adult X. laevis with FV3 leads to extensive recruitment of leukocytes, including a large number of cells with macrophage morphology, to the site of infection (Morales et al. 2010). The myeloid origins of these leukocytes are supported not only by their expression of macrophage inflammatory genes (TNF $\alpha$, IL-1 $\beta$, and Arginase-1; Morales et al. 2010), but also of the macrophagelineage marker, M-CSFR (L. Grayfer, F. De Jesús Andino and J. Robert, University of Rochester, unpublished data). Interestingly, while we have been able to amplify FV3 DNA from peritoneal leukocytes isolated from virus-infected frogs up to 21 days postinfection, FV3 early and late transcripts were detected at 6 , but not 15 or 21 days postinoculation (Morales et al. 2010). This suggests that the viral genome is maintained within macrophage-like cells in a state of dormancy. Possibly, the inability to detect FV3 genomes among peritoneal leukocytes at later times may reflect the dissemination of these cells to distal sites within the X. laevis host.

In Xenopus, the kidney represents a focal site of FV3 replication. Interestingly, active FV3 gene transcription is seen in some, but not all FV3-infected frogs for up to 9 days after infection, whereas viral genomic DNA may be amplified from some of these animals 2 weeks subsequent to viral challenge (Morales et al. 2010). Notably, this interval is shorter than the 3 -week period during which viral persistence is reliably detected within peritoneal leukocyte populations. These differences possibly reflect 
the distinct interactions between FV3 and these various cell targets. Presumably, kidney cells are productively infected and serve as sites of active FV3 replication, indicated by high viral titers and extensive tissue damage (Grayfer et al. 2014). Conversely, macrophage-lineage cells are terminally differentiated, nondividing, long-lived cells, which ostensibly serve as reservoirs for dormant (non-replicating) ranavirus.

Collectively, these observations implicate frog macrophage-lineage cells as central targets of FV3 infection, serving as likely cellular targets for persistence, quiescence, and dissemination. Indeed, we have recently observed that FV3 genomic DNA may be amplified from in vitro-infected, cultured peritoneal phagocytes without detectable viral gene expression as long as several months after initial infection (L. Grayfer, and J. Robert, University of Rochester, unpublished data). We believe that the key to further delineating ranavirus-macrophage interactions and ranaviral quiescence is contingent on developing in vitro myeloid cell cultures and related reagents.

\subsection{Macrophage Reservoirs and Ranavirus Reactivation}

We recently provided substantial support for the hypothesis that amphibian macrophages serve not only as vehicles of ranavirus dissemination within the host but also as foci of disease reactivation. When peritoneal phagocytes were isolated from $15 X$. laevis adults 30 days postinfection, only cells from one individual displayed detectable levels of FV3 DNA and expressed transcripts encoding the viral DNA polymerase and major capsid protein (J. Robert, L. Grayfer, and F. De Jesús Andino, University of Rochester, unpublished data). However, after i.p. injection of heat-killed E. coli, nine of the same 15 animals exhibited both detectable viral genomic DNA and active viral gene expression. In addition, immunofluorescence microscopy targeting 53R, an FV3 gene product required for replication and assembly, and HAM56, a X. laevis macrophage marker (Nishikawa et al. 1998), revealed that peritoneal macrophages displayed productive FV3 replication (Fig. 1). Thus, it appears that mononuclear phagocytes harbor low levels of viral DNA, which can be reactivated by inflammation. Further research into activation states (both classical and alternative; Auffray et al. 2007; Nahrendorf et al. 2007; Zhao et al. 2009; Ziegler-Heitbrock 2007) of mononuclear phagocytes will be critical to devising preventative measures and understanding the precise infection strategies of these complicated pathogens.

\subsection{Ranavirus Infections Among Other Poikilothermic Macrophages}

Akin to many other pathogens, ranaviruses presumably overcome macrophage antimicrobial and antiviral barriers, at which point these cells become vehicles for both viral dissemination and persistence. However, exploitation of macrophage-lineage 

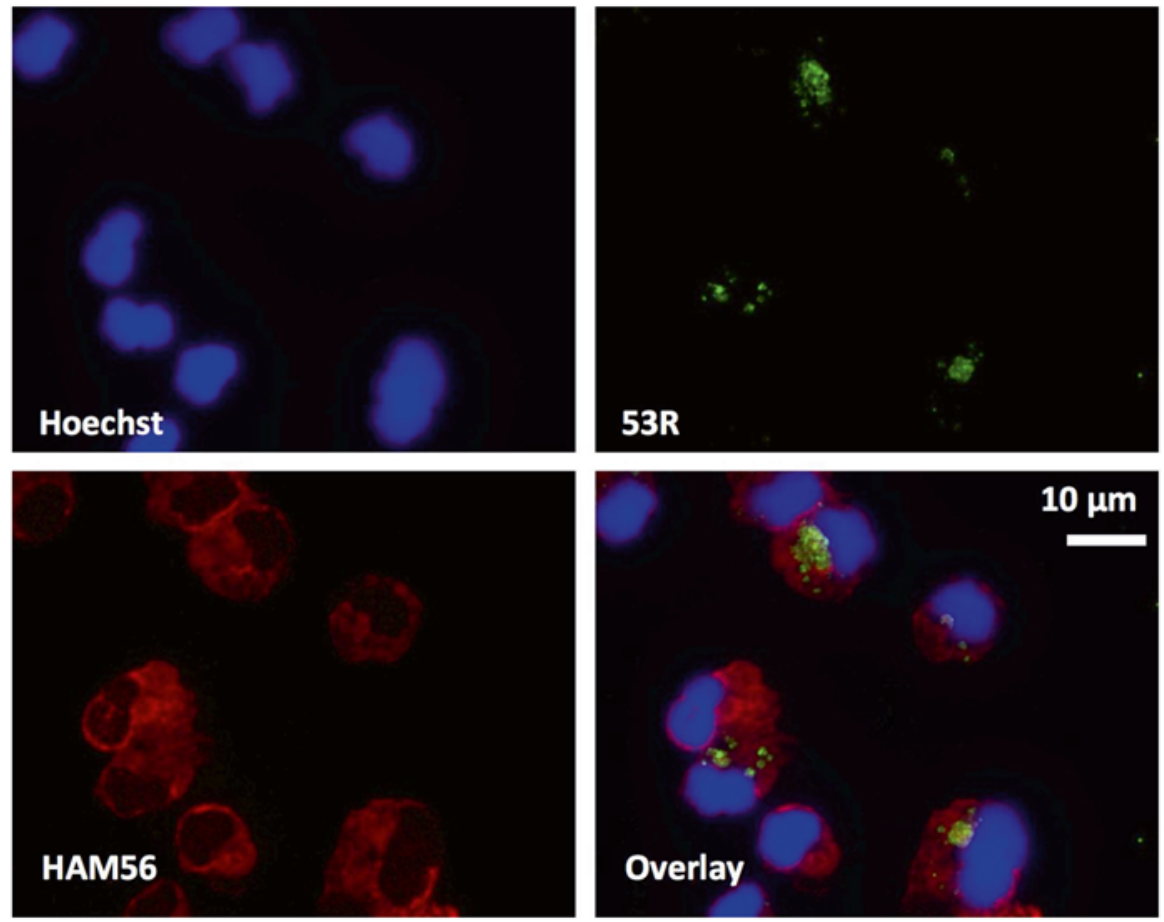

Fig. 1 Xenopus laevis HAM $56^{+}$peritoneal macrophages infected with Frog Virus 3. Xenopus laevis peritoneal leukocytes were infected at a multiplicity of infection (MOI) of 0.3 with Frog Virus 3. Macrophages were stained with an antibody against the macrophage marker HAM56. FV3 was visualized using an antibody against the 53R viral protein. Hoechst was used to visualize the cellular nuclei

cells as vectors of viral dissemination and persistence does not appear confined to FV3, as other members of the genus Ranavirus and family Iridoviridae have also adopted this mechanism of host infiltration and immune evasion. For example, an iridovirus-like pathogen infects sheatfish kidney macrophages and is capable of down-regulating phorbol myristate acetate-elicited reactive oxygen production by these cells in vitro (Siwicki et al. 1999). Likewise, following infection with the Taiwan Grouper Iridovirus (TGIV), elevated numbers of phosphatase-positive, highly phagocytic basophilic and eosinophilic mononuclear leukocytes were detected (Chao et al. 2004). Interestingly, TGIV genomic DNA was found only within the nuclei of mononuclear phagocytes at early times after infection, whereas at later times it was seen in both nuclear and cytosolic compartments and these cells lost their phagocytic capacity (Chao et al. 2004). Clearly, TGIV has evolved intricate and temporally regulated strategies for overcoming and utilizing the very immune cells that would presumably be coordinating the antiviral immune response. It is probable that the strategy of invading mononuclear phagocytes as a means of immune evasion and dissemination is a distinct feature of all vertebrate iridoviruses. 
Further development of in vitro primary macrophage cultures derived from relevant host species and infection models will provide additional insight into these infection strategies.

\section{Antiviral Immune Responses to Ranavirus Infections}

\subsection{Antiviral Interferons of Ectothermic Vertebrates}

The interferon (IFN) response provides a significant contribution to antiviral immunity. IFN responses generally arise as the result of recognition of viral products through an array of host pathogen recognition receptors (PRRs), including toll-like receptors (TLRs), retinoic acid-inducible gene 1-(RIG-I)-like receptors (RLRs), and cytosolic DNA sensors (Baum and Garcia-Sastre 2010; Sadler and Williams 2008). This branch of antiviral immunity consists of three classes of cytokines, type I, II, and III IFNs (Sadler and Williams 2008). IFN $\gamma$, the only type II IFN of mammals (n.b., bony fish possess multiple type II IFNs; Grayfer et al. 2010) plays multiple immune and antiviral roles, whereas IFN-I and -III function predominantly as antiviral molecules. Mammalian IFN-I possesses broad cellular specificities, whereas IFN-III targets specific cell subsets (Levraud et al. 2007; Zou et al. 2007). Interestingly, while the distinct receptor systems utilized by IFN-I and -III dictate cell specificity, both cytokine families activate the same downstream Janus kinase (JAK) and signal transducer and activator of transcription (STAT) signaling pathways, culminating in similar antiviral outcomes (Sadler and Williams 2008) including the induction of antiviral genes such as protein kinase $\mathrm{R}$ (PKR) and Myxovirus resistance $(\mathrm{Mx})$ molecules.

While these IFN responses are well studied among warm-blooded vertebrates, the cold-blooded hosts that are subject to ranavirus infection possess unique and much less understood IFN systems. The mammalian type I IFNs are encoded by intronless genes, comprising the multigene IFN $\alpha$ family (13 in humans) and a single IFN $\beta$ gene (Hervas-Stubbs et al. 2011). While reptiles and birds also express single exon-encoded type I IFNs (Robertsen 2006; Zou and Secombes 2011), lower vertebrate species including cartilaginous and bony fish as well as amphibians possess type I IFNs encoded by five exon/four intron transcripts and displaying marked sequence divergence from their mammalian counterparts (Chang et al. 2009; Qi et al. 2010; Robertsen 2006; Zou and Secombes 2011; Zou et al. 2007).

Presently, only the type I IFN systems of bony fish have been explored in detail. These IFNs are subdivided into two groups (group I: 2C; group II: 4C) based on cysteine patterns (Sun et al. 2009; Zou et al. 2007), and further classified into four groups (IFNa-d) according to phylogeny (Chang et al. 2009; Sun et al. 2009). Importantly, while multiple distinct mammalian IFNs confer their biological roles through the same receptor complex (Li et al. 2008; Samuel 2001), fish group I and 
II IFNs signal through unique receptor complexes (Aggad et al. 2009). Functional studies have been performed predominantly on group I type I fish IFNs (Aggad et al. 2009; Altmann et al. 2003; Long et al. 2004; Lopez-Munoz et al. 2009; Robertsen et al. 2003; Zou et al. 2007), and it has been demonstrated that these IFNs differ in their capacities to establish cellular antiviral states (Aggad et al. 2009; Levraud et al. 2007; Li et al. 2010; Lopez-Munoz et al. 2009). For example, salmonid IFNs a-d possess different transcriptional regulation patterns and distinct antiviral functions, as some of these cytokines are capable of eliciting potent antiviral responses while others are believed not to have antiviral functions at all (Svingerud et al. 2012). The type II IFN systems of amphibians and reptiles remain largely uncharacterized, whereas those of bony fish appear to be much more complex than that of mammals (Zou and Secombes 2011), and will not be addressed further here.

Mammalian IFN-III is comprised of interferon lambda (IFN $\lambda$ ) -1, -2, and -3 (also designated as IL-28A, IL-28B, and IL-29). These molecules are encoded by five exon/four intron gene transcripts and signal through a receptor system composed of the interferon lambda receptor-1 (IFN $\lambda$ R1) and interleukin-10 receptor-2 (IL-10R2; reviewed in reference Kotenko 2011). Intriguingly, while bona fide type III IFNs either do not exist, or have not yet been identified in bony fish, amphibians are now known to possess both type I IFNs with the same five exon/four intron gene organization as their fish counterparts, as well as true type III IFNs (Qi et al. 2010). This is especially relevant when considering that amphibians are key evolutionary intermediates between fish and mammals and inhabit both aquatic and terrestrial habitats. In fact, a hallmark characteristic of fish and amphibian type I IFNs is the five exon/four intron genomic organization, which is distinct from the reptile, avian and mammalian intronless type I IFNs (Robertsen 2006; Robertsen et al. 2003; Sun et al. 2009). Hitherto, there has been substantial debate regarding the precise phylogenetic relationship of fish IFN-I to higher vertebrate IFN-I and -III. Fish cytokines exhibit exon/intron gene organization similar to that of mammalian type III IFNs, yet possess hallmarks of higher vertebrate type I IFNs such as conserved cysteine positioning and (with the exception of the catfish IFN-I) a C-terminal CAWE motif, a conserved sequence motif found within nearly all IFNs (Lutfalla et al. 2003; Qi et al. 2010; Robertsen 2006; Zou et al. 2007). It will be interesting to determine the respective roles of these molecules in fish and amphibian antiviral immunity to RVs, particularly considering that fish appear to only have type I IFNs, while frogs possess both IFN types I and III (Qi et al. 2010).

\subsection{Interferon Response to Ranavirus Infection}

As described above, an important antiviral gene product synthesized during the interferon response is the Myxovirus resistance (Mx) protein (Samuel 2001). Mx proteins are believed to be pivotal to the establishment of the antiviral state conferred by IFN (Samuel 2001). Mx proteins are high molecular weight GTPases 
belonging to the dynamin superfamily and are known to facilitate intracellular membrane remodeling as well as intracellular trafficking (Kochs et al. 2005). As in mammals, teleost Mx proteins function as antiviral mediators, with distinct Mx isoforms from different species conferring somewhat unique antiviral effects. To date the Mx of most, but not all, fish species have proven ineffective in preventing infection by various members of the family Iridoviridae. For example, Japanese flounder $\mathrm{Mx}$ is capable of inhibiting the replication of two species of rhabdovirus, but is incapable of inhibiting replication of Red seabream iridovirus (RSIV, genus Megalocytivirus; family Iridoviridae) (Caipang et al. 2003). Similarly, Barramundi $\mathrm{Mx}$ inhibits replication of the nodavirus viral nervous necrosis virus (VNNV) and of Infectious pancreatic necrosis virus (IPNV) but fails to show antiviral effects against Taiwan grouper iridovirus (TGIV) (Wu et al. 2012; Wu and Chi 2007). Likewise, Senegalese sole Mx confers antiviral effects against the IPNV and Viral hemorrhagic septicemia virus (VHSV, family Rhabdoviridae), but not against the ranavirus European sheatfish virus (ESV) (Alvarez-Torres et al. 2013). Finally, rainbow trout Mx1 is antiviral towards IPNV, Salmonid alpha virus (SAV, Togaviridae), and infectious hematopoetic necrosis virus (IHNV, Rhabdoviridae), but is not effective at blocking replication of EHNV (Lester et al. 2012; Trobridge et al. 1997). Possibly, the host antiviral responses coevolved with local ranaviral isolates. Thus, the inadequacy of antiviral components such as Mx1 in dealing with foreign ranaviral isolates may culminate in a global threat represented by geographically distant ranavirus strains introduced by subclinically infected migratory hosts or imported due to international trade.

Perhaps the most commercially and aquaculturally important fish species in southern Europe is the gilthead seabream, at least in part because of its natural resistance to most viral pathogens (Cano et al. 2006, 2009). In fact, the only viral disease affecting commercial seabream populations is Lymphocystis disease virus (LCDV, genus Lymphocystivirus, family Iridoviridae) (Cano et al. 2013). Interestingly, seabream possess at least three $\mathrm{Mx}$ proteins. One $\mathrm{Mx}$ isoform effectively inhibits replication of VHSV and LCDV, a second Mx molecule effectively inhibits replication of European sheatfish virus and LCDV, and the third is protective against VHSV (Alvarez-Torres et al. 2013; Fernandez-Trujillo et al. 2013). This represents the first example of a teleost Mx molecule effectively inhibiting DNA virus infection. This is interesting, considering that LCDV nonetheless plagues this species. It is noteworthy that in contrast to the mortality caused by many members of the family Iridoviridae, seabream effectively clear LCDV infections, although it is believed that they may harbor the virus non-symptomatically. Thus, the efficacy of the teleost IFN/Mx response may well dictate the susceptibility of individual fish species to highly virulent pathogens such as iridoviruses. Notably, many fish species are infected by, and clear LCDV. Since these infections involve fish skin (Leibovitz 1980), systemic antiviral responses such as Mx may be less important to the resolution of LCDV.

In another example, Japanese flounder IFN-inducible transmembrane (IFITM) protein is upregulated in response to Rana grylio virus (RGV) infections (Zhu et al. 2013). Furthermore, through overexpression and siRNA knockdown studies, flounder IFITM1 was shown to play an important role in the cellular antiviral response to 
RGV (Zhu et al. 2013). IFITM1 functions by suppressing viral-host cell entry and targeting the Golgi apparatus (Zhu et al. 2013).

As more research is conducted on these individual antiviral components, it is becoming more apparent that there are key, previously unknown factors that participate in the antiviral response of not just poikilotherms, but all vertebrate species. We propose that these individual IFN-elicited antiviral components are most likely interdependent on entire networks of other IFN-regulated molecules. Thus, the relative potency of the antiviral IFN response, at both cellular and whole organism levels, relies on the balance of numerous cellular and molecular components. Since different fish and amphibian species are now known to possess very distinct repertoires of antiviral effector molecules, it is not surprising that these disparate organisms display very different susceptibilities to similar pathogens.

Microarray analysis of axolotls infected with ATV revealed that in addition to a multifaceted inflammatory gene response, these animals also upregulate expression of multiple antiviral interferon responsive genes (Cotter et al. 2008). Among the numerous genes elicited by ranavirus infection were $\mathrm{Mx} 1$ genes, antiviral helicases, interferon regulatory factors, an IFITM, and a ribonuclease (Cotter et al. 2008). However, the genes encoding axolotl type I and type III IFN remain to be identified. It will be important to delineate the precise repertoire(s) of antiviral IFNs present within the axolotl genome and examine the transcriptional regulation, as well as functional roles of these moieties during immune responses against ranaviruses such as ATV.

As described above, frogs are now known to possess both type I and type III IFN genes that are transcriptionally upregulated following virus infections (Qi et al. 2010). While there have been no reported functional studies of amphibian type III IFNs, we recently identified a $X$. laevis type I IFN, produced it in recombinant ( $\mathrm{r} X l \mathrm{IFN}$ ) form and characterized this molecule in the context of FV3 infections (Grayfer et al. 2014). Pretreatment of $X$. laevis A6 kidney-derived epithelial cell cultures with $\mathrm{rXIIFN}$ significantly protected these cells against the cytolytic effects of FV3 (Grayfer et al. 2014). Although control cultures were almost entirely decimated 3 days following FV3 infection and exhibited extensive viral replication, $\mathrm{rXlIFN-treated} \mathrm{cultures} \mathrm{were}$ virtually FV3-free and thriving (Grayfer et al. 2014). Furthermore, treatment of A6 cells with $\mathrm{r} X I \mathrm{IFN}$ significantly upregulated the expression of Mx1 indicating that stimulation with this cytokine elicits a cellular antiviral state (Grayfer et al. 2014). Following FV3 challenge, the type I IFN response was more robust in X. laevis adults than tadpoles (Grayfer et al. 2014). Nevertheless, tadpoles injected i.p. with rXlIFN exhibited significant increases of Mx1 gene expression in the spleen and peritoneal leukocytes (Grayfer et al. 2014). Moreover, upon FV3 challenge, rXlIFN-treated tadpoles showed decreased viral replication and transcriptional activity (Grayfer et al. 2014). Therefore, in addition to delayed innate and inflammatory-associated immune gene responses, it appears that an inadequate type I IFN response also contributes to the higher susceptibility of $X$. laevis tadpoles to FV3.

However, adding to the complexity of the interaction between FV 3 and tadpoles is the fact that although $\mathrm{r} X I \mathrm{IFN}$-treated tadpoles exhibited prolonged mean survival times following FV3 inoculation and viral loads that were several logs lower, these animal nonetheless incurred extensive organ damage and succumbed to infection 
(Grayfer et al. 2014). This is consistent with the notion (as described above) that depending on the species and/or developmental stage, ranaviruses may exhibit virulence factors independent of viral replication. It is intriguing that despite the antiviral potency of $X$. laevis IFN, FV3 ultimately results in tadpole mortality. It will be invaluable to elucidate the respective roles of amphibian type I and III IFNs, their cognate receptor systems, and the respective roles (and possibly defects) of these components during ranavirus infections of tadpole and adult frogs.

\section{Adaptive Immune Responses to Ranavirus Infections}

Anti-ranavirus immune responses of lower vertebrates are multifaceted, complex, and poorly understood. However, it is becoming evident that clearance of ranaviruses is heavily contingent on successful adaptive immune responses, which have been investigated to date almost exclusively in X. laevis.

\subsection{Antibody Responses to Ranavirus Infection}

The amphibian organization and usage of the immunoglobulin (Ig) heavy and light chain loci are reminiscent of their mammalian counterparts, including V-(D)-J rearrangements, class-switch recombination, somatic hypermutation, and affinity maturation (Du Pasquier et al. 1989, 2000; Hsu 1998). As in mammals, the Xenopus Ig class-switch from $\operatorname{IgM}$ to $\operatorname{IgY}$ (IgG analog) is thymus-dependent and requires T cell-B cell collaboration (Blomberg et al. 1980; Turner and Manning 1974). Although affinity maturation of amphibian IgY results in only a tenfold increase, as compared to the 10,000-fold increase seen with for mammalian IgGs, it has been clearly demonstrated that Xenopus humoral immunity is a significant contributing factor to anti-ranaviral immune responses, particularly of adult frogs (Maniero et al. 2006).

Following secondary FV3 infection of $X$. laevis adults, animals produce substantial amounts of virus-specific IgY, first detectable 1 week after infection and peaking around 3 weeks after challenge (Gantress et al. 2003). Indeed, frogs re-infected (in the absence of adjuvant) with FV3 up to 15 months post primary infection, develop antiFV3 specific IgY antibodies in a thymus-dependent manner that are detectable from 10 days up to 8 weeks post re-immunization (Maniero et al. 2006). Notably, FV3 is effectively neutralized by exposure to this sera in vitro (Maniero et al. 2006). In addition, administration of immune sera to naturally susceptible $X$. laevis tadpoles immediately preceding FV3 infection confers partial, but significant passive protection against the virus (Maniero et al. 2006). Clearly, the amphibian antibody response is integral to the clearance of ranavirus infections, while the extent to which this particular immune mechanism contributes to the ultimate anti-ranaviral immunity seen in Xenopus adults remains to be determined. These results are consistent with findings 
with Red seabream iridovirus (RSIV, genus Megalocytivirus) in which vaccination with inactivated virions protected fish from subsequent viral challenge (Caipang et al. 2006; Nakajima and Kunita 2005; Nakajima et al. 1999)

\subsection{T Cell Responses and Immunological Memory Against Ranavirus Infections}

X. laevis tadpoles express suboptimal levels of MHC class Ia protein (Du Pasquier et al. 1989) and yet their splenocytes include bona fide CD8 T cells that express the pan-T Xenopus cell-surface marker CD5 (Jurgens et al. 1995) and exhibit fully rearranged TCR $\alpha / \beta$ transcripts (Horton et al. 1998). It is possible that suboptimal class Ia protein expression in tadpoles results in a $\mathrm{T}$ cell differentiation and selection pathway distinct from that of post-metamorphic animals and relies more heavily on non-polymorphic nonclassical MHC class Ib (class Ib) molecules. Indeed, in the absence of optimal class Ia-mediated T cell selection, larval CD8 T cells may possess a more restricted antigen-binding repertoire, possibly reflected in the relative susceptibility of tadpoles to ranaviruses. However, as discussed later in this section, there are distinct class Ib-mediated $\mathrm{T}$ cell selection mechanisms and $\mathrm{T}$ cell subsets that may complement conventional class Ia-restricted CD8 T cells in tadpoles.

In contrast to tadpoles, adult $X$. laevis display conventional class Ia-restricted CD8 cytotoxic T cell populations. Despite the absence of available antibodies, CD4 $\mathrm{T}$ helper cells are also likely present owing to the presence of all genes involved in differentiation and function of CD4 T cells, the expression of the CD4 gene in $\mathrm{CD}^{-} / \mathrm{CD}^{+}$cells, and the MHC class II-dependent proliferation response obtained by mixed lymphocyte reaction (Du Pasquier et al. 1989). The requirement of T cells for FV3 clearance in $X$. laevis adults has been demonstrated by using sub-lethal $\gamma$-irradiation, which depletes thymus-derived $\mathrm{T}$ cells. Irradiated $\mathrm{T}$ cell-depleted adult frogs do not control FV3 and succumb to infection (Robert et al. 2005). Furthermore, depletion of $X$. laevis CD8 T cells by administration of anti-X. laevis CD8 mAb also substantially increases adult frog susceptibility to FV3 infection (Robert et al. 2005). These CD8 T cell-depleted, FV3-infected animals experienced severe edema and hemorrhaging, extensive elevation of viral loads and succumbed to infections, whereas control cohorts effectively cleared the virus (Robert et al. 2005). Thus, cytotoxic CD8 T cell responses are critical for effective FV3 clearance. Intriguingly, administration of the anti-CD8 Ab to tadpoles did not result in either CD8 T cell depletion or in increased susceptibility to FV3 (Robert et al. 2005), again emphasizing the unconventional nature of the tadpole $\mathrm{T}$ cell populations.

Frogs re-infected with FV3 exhibit expedited viral clearance concomitant with earlier proliferation of $\mathrm{CD}^{+} \mathrm{CD}^{+}$splenocytes and faster infiltration ( $3 \mathrm{vs}$. $6 \mathrm{dpi}$ ) of the kidney, the central site of X. laevis-FV3 replication (Morales and Robert 2007). This not only underlines the importance of CD8 T cells in ranaviral clearance, but also indicates the presence of a $\mathrm{T}$ cell memory responses to ranavirus re-infections in adult 
$X$. laevis. Interestingly, while kidney infiltration was substantially accelerated upon secondary FV3 challenge compared to primary infections, the numbers of recruited $\mathrm{CD}^{+}$cells were substantially lower during this second immune event (Morales and Robert 2007). This could be attributed to a higher frequency of T cell precursor infiltration upon the primary response and/or the generation of lowers number of more effective CD8+ memory T cells upon re-infection. It cannot be excluded that this modest secondary response is an inherent property of the evolutionarily primordial amphibian adaptive immune system, considering the relatively meager degree of $\mathrm{T}$ cell expansion seen following immunological challenges, the absence of draining lymph nodes and the lack of white pulp-red pulp splenic organization (Du Pasquier et al. 1989). Alternatively, this modest secondary CD8 response could be accounted for by the recruitment and immune involvement of additional effector populations during subsequent anti-ranavirus responses. In support of this notion, during the secondary anti-FV3 response, there is the rapid and robust recruitment, and kidney infiltration of, $\mathrm{CD}^{-} \mathrm{MHCII}^{+}$immune populations, which may be $\mathrm{B}$ cells, CD4 T cells, or $\mathrm{CD}^{-}$nonclassical MHC (class Ib)-restricted invariant $\mathrm{T}$ cell populations.

\subsection{Roles of Nonclassical MHC-Restricted Cells in Ranavirus Immunity}

Nonclassical MHC class Ib (Ib) molecules exhibit structural similarities to class Ia molecules, but typically possess limited tissue distribution and substantially fewer polymorphisms (Flajnik and Kasahara 2001). In mammals, some of these surface glycoproteins are involved in the differentiation and functional regulation of distinct subsets of invariant T (iT) cells, including CD1d-restricted iNKT cells and MR1 restricted mucosal associated iT (MAIT) cells (Bendelac et al. 1995, 1996, 1997; Matsuda and Gapin 2005). Both of these lymphocyte populations undergo unconventional differentiation pathways, exhibit unique semi-invariant $\mathrm{T}$ cell receptor rearrangements and are believed to participate in antimicrobial and antiviral immune responses (Behar and Porcelli 2007; Choi et al. 2008; Cohen et al. 2009; Le Bourhis et al. 2010).

It is intriguing that, as described above, while Xenopus larvae are naturally MHC class Ia deficient (Du Pasquier et al. 1989), they express a number of nonclassical class Ib genes (XNCs), with some of these, such as XNC10 displaying preferential thymic expression (Goyos et al. 2009, 2011). Notably, we have recently identified a prominent $X$. laevis iT immune cell subset, which requires XNC10 for both its development and function (Edholm et al. 2013). Using an XNC10 tetramer as well as reverse genetics combining transgenesis and RNA interference, we determined that this iT cell population is $\mathrm{CD}^{-} / \mathrm{CD}^{-}$, expresses a semi-invariant $\mathrm{T}$ cell receptor consisting of an invariant TCR $\alpha(\mathrm{iV} \alpha 6-\mathrm{J} \alpha 1.43)$ combined with a limited TCR $\beta$ repertoire, and fails to develop in the absence of, or with diminished, XNC10 expression (Edholm et al. 2013). Notably, transgenic animals with effectively RNAisilenced thymic and splenic XNC10 expression failed to develop this iT cell subset. 
Moreover, they were also significantly more susceptible to, and more readily succumbed to, FV3 infections (Edholm et al. 2013) suggesting that these cells are important in anti-ranaviral defenses. It is noteworthy that deep sequencing analysis of tadpole TCR $\alpha$ revealed that Xenopus larvae possess several additional predominant iT cell populations (Edholm et al. 2013), which are presumably XNC-restricted and most likely participate in immune responses such as those against ranaviruses. Indeed, we have also identified the XNC10-dependent iT cell population in adult frogs; thus it stands to reason that during the primary and secondary anti-FV3 responses, these lymphocyte subsets may be amongst the CD8- kidney infiltrating immune populations (Morales and Robert 2007) discussed above. Table 1 provides a comprehensive summary of host immune strategies.

\section{Ranaviral Strategies for Evading Host Antiviral Immunity}

As seen with poxviruses and other large DNA viruses, ranaviruses likely encode multiple proteins that function to impede the host antiviral response (Finlay and McFadden 2006; Johnston and McFadden 2003; Seet et al. 2003). However, with the exception of the ranavirus homolog of the largest subunit of eukaryotic initiation factor 2 (vIF- $2 \alpha$ ), the functions of these gene products have not been determined. A description of the role of vIF- $2 \alpha$ follows, along with a brief description of other potential immune evasion proteins.

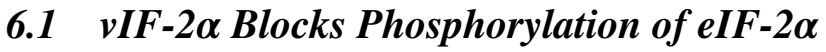

Protein kinase $\mathrm{R}(\mathrm{PKR}, \mathrm{EIF} 2 \alpha \mathrm{K} 2)$ is a protein kinase that regulates cellular protein synthesis via phosphorylation and inactivation of the alpha subunit of eukaryotic translation initiation factor 2 (eIF $2 \alpha)$ in response to a variety of environmental stressors including viral infection (Proud 1995; Toth et al. 2006). PKR is present at low levels within uninfected cells and is induced following cell stimulation by antiviral IFNs. PKR is an inactive monomer in uninfected cells. However, during viral infection, low concentrations of viral dsRNA bind PKR leading to its dimerization and activation via autophosphorylation (Zhang et al. 2001). Activated PKR subsequently phosphorylates the alpha subunit of eIF-2, an event that results in a global arrest in protein synthesis (Panniers et al. 1988; Rowlands et al. 1988). In addition to the effect of PKR-mediated eIF- $2 \alpha$ inactivation on protein synthesis, activated PKR may play additional roles. Activated PKR phosphorylates an inhibitor, I- $\kappa \mathrm{B}$, bound to NF- $\mathrm{KB}$ leading to the latter's release and the subsequent activation of proinflammatory and interferon genes (Proud 1995). In addition, activated PKR appears to be one of the danger signals that trigger apoptosis in virus infected cells. Because of the adverse effects that translational inhibition, NF- $\kappa \mathrm{B}$ activation, and apoptosis have on virus replication, viruses have evolved numerous approaches for circumventing PKR-mediated antiviral functions (Diener et al. 1993; Katze 1992). 
Table 1 Current understanding of anti-ranaviral immune defenses

\begin{tabular}{|c|c|c|c|}
\hline Immune parameter & Species & Immune outcome & Reference \\
\hline \multicolumn{4}{|l|}{ Cellular immunity } \\
\hline \multirow[t]{4}{*}{$\begin{array}{l}\text { Macrophage-lineage } \\
\text { cells }\end{array}$} & X. laevis & $\begin{array}{l}\text { M } \phi \text { recruitment to FV3 } \\
\text { inoculum }\end{array}$ & Morales et al. (2010) \\
\hline & X. laevis & FV3 reservoirs & Robert et al. (2007) \\
\hline & E. lanceolatus & TGIV reservoirs & Chao et al. (2004) \\
\hline & S. glanis & $\begin{array}{l}\text { TGIV inhibits kidney } \\
\text { phagocyte ROI }\end{array}$ & Siwicki et al. (1999) \\
\hline Innate immunity & A. mexicanum & $\begin{array}{l}\text { Innate immune responses } \\
\text { to ATV }\end{array}$ & Cotter et al. (2008) \\
\hline NK cell response & X. laevis & NK cell recruitment to FV3 & Morales et al. (2010) \\
\hline CD8 responses & X. laevis & $\begin{array}{l}\text { Recruitment to and clearance } \\
\text { of FV3 }\end{array}$ & Morales et al. (2010) \\
\hline $\begin{array}{l}\text { Absence of } \\
\text { lymphocyte } \\
\text { responses }\end{array}$ & A. mexicanum & $\begin{array}{l}\text { Lack of adaptive immunity } \\
\text { linked to ATV susceptibility }\end{array}$ & Cotter et al. (2008) \\
\hline $\begin{array}{l}\text { Nonclassical MHC } \\
\text { Ib restricted iT cells }\end{array}$ & X. laevis & $\begin{array}{l}\text { Poorly understood protection } \\
\text { against FV3 in tadpoles and } \\
\text { adult frogs }\end{array}$ & Edholm et al. (2013) \\
\hline \multicolumn{4}{|l|}{ Humoral immunity } \\
\hline \multirow[t]{2}{*}{$\begin{array}{l}\text { Antimicrobial } \\
\text { peptides }\end{array}$} & R. pipiens & $\begin{array}{l}\text { Disruption of FV3 viral } \\
\text { envelopes }\end{array}$ & $\begin{array}{l}\text { Chinchar et al. } \\
(2001)\end{array}$ \\
\hline & R. dybowskii & Inhibition of RGV infectivity & Yang et al. (2012) \\
\hline $\operatorname{IgY}$ & X. laevis & $\begin{array}{l}\text { FV3 clearance; memory } \\
\text { response to re-infection }\end{array}$ & $\begin{array}{l}\text { Du Pasquier et al. } \\
(1989,2000) \\
\text { Hsu }(1998)\end{array}$ \\
\hline \multicolumn{4}{|l|}{ Inflammatory cytokines } \\
\hline \multirow[t]{2}{*}{$\mathrm{TNF} \alpha$} & X. laevis & $\begin{array}{l}\text { Expression correlates with } \\
\text { anti-RV protection; more } \\
\text { modest and delayed in } \\
\text { tadpoles }\end{array}$ & Morales et al. (2010) \\
\hline & $E P C$ cell line & Induced by FV3 & $\begin{array}{l}\text { Holopainen et al. } \\
(2012)\end{array}$ \\
\hline IL-1 $\beta$ & X. laevis & $\begin{array}{l}\text { Expression correlates with } \\
\text { anti-FV3 protection; more } \\
\text { modest and delayed in } \\
\text { tadpoles }\end{array}$ & Morales et al. (2010) \\
\hline $\mathrm{IFN} \gamma$ & X. laevis & $\begin{array}{l}\text { Expression correlates with } \\
\text { anti-FV3 protection; more } \\
\text { modest and delayed in } \\
\text { tadpoles }\end{array}$ & $\begin{array}{l}\text { De Jesús Andino } \\
\text { et al. (2012) }\end{array}$ \\
\hline \multicolumn{4}{|l|}{ Antiviral immunity } \\
\hline Mx & S. aurata & Inhibits ESV replication & $\begin{array}{l}\text { Alvarez-Torres et al. } \\
\text { (2013); Fernandez- } \\
\text { Trujillo et al. (2013) }\end{array}$ \\
\hline IFN inducible genes & A. mexicanum & ATV-elicited expression & Cotter et al. (2008) \\
\hline IFITM1 & P. olivaceus & $\begin{array}{l}\text { Cellular antiviral response to } \\
\text { RGV }\end{array}$ & Zhu et al. (2013) \\
\hline Type I IFN & X. laevis & $\begin{array}{l}\text { Expression correlates with } \\
\text { anti-FV3 protection; more } \\
\text { modest and delayed in } \\
\text { tadpoles }\end{array}$ & Grayfer et al. (2014) \\
\hline
\end{tabular}


To block phosphorylation of eIF- $2 \alpha$, ranaviruses encode a pseudosubstrate of eIF- $2 \alpha$ designated vIF- $2 \alpha$. In most ranaviruses, vIF- $2 \alpha$ is present as protein, of about 250 amino acid residues in length, that contains a sequence motif (V[L/I] RVDxxKGY[V/I]D) common to multiple ranaviruses, host cell eIF-2 $\alpha$, and the K3L protein of vaccinia virus (Majji et al. 2006). K3L has been shown to block the phosphorylation and subsequent inactivation of eIF- $2 \alpha$ by acting as a pseudosubstrate for PKR (Beattie et al. 1995), and vIF-2 $\alpha$ has been shown to function in similar fashion (see below). By using an ATV KO mutant lacking vIF-2 $\alpha$, Jancovich and Jacobs (Jancovich and Jacobs 2011) showed that this mutant virus was more sensitive to IFN-mediated inhibition and failed to block the phosphorylation of eIF-2 $\alpha$. Moreover, whereas wt ATV degraded fish PKZ, an IFN-inducible kinase similar to $\mathrm{PKR}$, the KO mutant did not. Lastly, the KO mutant displayed reduced virulence in vivo suggesting that vIF- $2 \alpha$ is a virulence gene. A similar attenuation of virulence was observed following infection of Xenopus laevis with a FV3 KO mutant lacking a truncated version of vIF- $\alpha$ (Chen et al. 2011). Truncated versions of vIF- $2 \alpha$ are found in FV3, soft-shell turtle iridovirus, and Rana grylio virus and are missing the N-terminal half of the native molecule. Since this region contains the VxRVDxxKGYxD motif described above, the reduction in virulence cannot be due to an effect of vIF- $2 \alpha$ on PKR, but to some element present within the $\mathrm{C}$-terminal half of the protein.

Rothenburg et al. (2011), using a yeast model, demonstrated that transfection of a vector expressing either human or zebrafish PKR into yeast cells resulted in marked cell death. Furthermore, in confirmation of the role of VIF- $2 \alpha$ as an antagonist of PKR, co-transfection of a vector expressing the full-length vIF- $2 \alpha$ gene from Rana catesbeiana virus (RCV) along with PKR blocked the toxic effects of both human and zebrafish PKR. Indicative of species specificity, vaccinia virus K3L was only able to block the activity of human PKR. Although the above study indicates a role for vIF- $2 \alpha$ in maintaining protein synthesis in virus-infected cells, the observation that FV3 and other closely related ranaviruses contain truncated vIF- $2 \alpha$ genes lacking critical N-terminal motifs indicates that vIF- $2 \alpha$ may not be the only ranavirus protein that plays a role in maintaining protein synthesis in virus infected cells.

\subsection{RNAse III-Like Proteins}

Similar to poxviruses, ranaviruses may also contain at least two genes whose function is to prevent the activation of PKR. Vaccinia virus encodes both the aforementioned K3L gene and a second gene, E3L, which binds dsRNA and prevents the dimerization and activation of PKR (Langland and Jacobs 2002; Langland et al. 2006). Although no ranavirus protein with homology to E3L has been detected, an RNAse III-like protein has been identified. RNAse-III targets dsRNA and it is possible that ranavirus homologs bind virus-induced dsRNA and degrade it, or block its ability to interact with and activate PKR. Experiments to directly test this hypothesis have not been reported. Moreover, knock down of RNAse III-like protein 
expression using antisense morpholino oligonucleotides resulted in a $40 \%$ reduction in virus yield (K. Cheng and V.G. Chinchar, University of Mississippi, unpublished data) suggesting that the RNaseIII-like protein plays a role in virus replication.

\section{$6.3 \quad \beta$-Hydroxysteroid Dehydrogenase and vCARD}

Ranaviruses, like poxviruses, contain proteins with homology to $\beta$-hydroxysteroid dehydrogenase ( $\beta$ HSD). $\beta$ HSD plays a role in steroid synthesis and expression of a $\beta$ HSD homolog by vaccinia virus results in suppression of immunity and an increase in viral replication (Sroller et al. 1998). vCARD is a $10 \mathrm{kDa}$, virus-encoded protein that contains a Caspase Activation and Recruitment Domain (CARD) motif that modulates interaction between proteins bearing similar domains (Kawai and Akira 2009, 2010). Because proteins involved in apoptosis or in the induction of IFN and pro-inflammatory molecules such as RIG-I, MDA5, and MAVS contain CARD motifs, it is postulated that vCARD interacts with one or more of these signaling molecules and short-circuits cellular antiviral immunity (Besch et al. 2009; Meylan et al. 2005).

\section{4 vTNFR, dUTPase, DMTase}

In addition to the four viral gene products mentioned above, ranaviruses also contain homologs of Tumor Necrosis Factor (TNF) receptor (vTNFR) and dUTPase (Chinchar et al. 2009; Eaton et al. 2007) and a unique virus-encoded DNA cytosine methyltransferase (DMTase). Similar to their poxvirus counterparts, ranavirus vTNFR could function as a decoy molecule and block protection mediated by TNF $\alpha$. Although dUTPase is generally considered to be a protein that plays a role in viral DNA synthesis (e.g., by increasing dTTP pools or blocking the incorporation of dUTP into DNA), a herpesvirus dUTPase was shown to also block antiviral immunity (Glaser et al. 2006; Oliveros et al. 1999). Lastly, the ranavirus DMTase may play a role in immune evasion by methylating cytosine residues within $\mathrm{CpG}$ motifs and blocking recognition by TLR-9 or cytoplasmic DNA sensors and preventing the subsequent induction of IFN and pro-inflammatory cytokines (Krieg 2002; Krug et al. 2004).

The above list of putative immune evasion proteins is based on ranavirus proteins with detectable homology to proteins in other systems with known antiviral effects. While this serves as a useful starting point in the identification and characterization of ranaviral immune evasion genes, there are approximately a dozen additional ORFs of unknown function, which are unique to ranaviruses. Whether these ORFs encode proteins that control virus replication in specific hosts or whether they encode proteins that modulate host-specific immune responses remains to be determined. 
Knock-down experiments using antisense morpholino oligonucleotides or siRNA and infections using knock-out mutants will be needed to resolve the function of these unique ranavirus-specific proteins.

\section{Concluding Remarks and Future Directions}

It is evident from the studies described here that anti-ranaviral immunity is multifaceted, complex, and likely species- and developmental stage-specific. Also evident are the many gaps in our understanding of the immune response to these pathogens as well as possible defects in the host's ability to mount effective responses that contain and eliminate these infections. It is particularly worrisome that Ranavirus and other genera within the family Iridoviridae have devised numerous, highly efficient strategies for evading, and even utilizing host immune components, to achieve persistence, facilitate dissemination and expand host range. Clearly, ranaviruses encode a large number of putative gene products, which represent both potential virulence factors as well as promising targets for future therapeutic interventions.

While it is easy to dismiss lower vertebrate immune systems as functionally analogous to those of mammals, there is a growing literature suggesting otherwise. It is through the fundamental understanding of the physiological and ecological pressures governing these unique immune systems that we may begin to comprehend ranavirus infection strategies and the immune systems that may, or may not have adequately co-evolved to stop them.

The investigation of ranavirus infection and immune subversion strategies should be approached not only by taking into account well-defined mammalian pathogens, but also by considering the possibility that ranaviruses may represent unique viral agents. In contrast to the majority of homeothermic vertebrate pathogens, ranaviruses are extraordinary in their ability to overcome cell and host tropism barriers, while their mechanisms of pathogenicity appear to be (at least partially) much less dependent on viral loads. Indeed, the immune systems of ectothermic hosts have evolved as the result of, and are subject to, different physiological and pathogenic pressures than those that have shaped the mammalian immune system. It stands to reason that ranavirus pathogens have co-evolved with these unique immune systems, thus we must garner greater insights into both to fully understand either.

Acknowledgments We thank Louise Rollins-Smith (Vanderbilt University) for reviewing an earlier draft of the manuscript. L. Grayfer was supported by postdoctoral fellowships from the Natural Sciences and Engineering Research Council of Canada and the Howard Hughes Medical InstituteLife Sciences Research Foundation. F. De Jesús Andino research support D14ZO-084 from the Morris Foundation. J. Robert and E.S. Edholm research support: 2 R24 Al 059830-10 from the NIH, and J. Robert and V.G. Chinchar IOS-0923772 and IOS-0742711 from the NSF.

Open Access publication was made possible through grants provided by the University of Tennessee (Institute of Agriculture, Office of Research and Engagement, and Department of Forestry, Wildlife and Fisheries), Washington State University Libraries, Gordon State College (Office of Academic Affairs), the Association of Reptilian and Amphibian Veterinarians, and the Amphibian and Reptile Conservancy. 
Open Access This chapter is distributed under the terms of the Creative Commons Attribution Noncommercial License, which permits any noncommercial use, distribution, and reproduction in any medium, provided the original author(s) and source are credited.

\section{References}

Aggad D, Mazel M, Boudinot P et al (2009) The two groups of zebrafish virus-induced interferons signal via distinct receptors with specific and shared chains. J Immunol 183:3924-3931

Altmann SM, Mellon MT, Distel DL et al (2003) Molecular and functional analysis of an interferon gene from the zebrafish, Danio rerio. J Virol 77:1992-2002

Alvarez-Torres D, Garcia-Rosado E, Fernandez-Trujillo MA et al (2013) Antiviral specificity of the Solea senegalensis Mx protein constitutively expressed in CHSE-214 cells. Mar Biotechnol (NY) 15:125-132

Aubertin AM, Hirth C, Travo C et al (1973) Preparation and properties of an inhibitory extract from frog virus 3 particles. J Virol 11:694-701

Auffray C, Fogg D, Garfa M et al (2007) Monitoring of blood vessels and tissues by a population of monocytes with patrolling behavior. Science 317:666-670

Baum A, Garcia-Sastre A (2010) Induction of type I interferon by RNA viruses: cellular receptors and their substrates. Amino Acids 38:1283-1299

Bayley AE, Hill BJ, Feist SW (2013) Susceptibility of the European common frog Rana temporaria to a panel of ranavirus isolates from fish and amphibian hosts. Dis Aquat Organ 103: 171-183

Beattie E, Paoletti E, Tartaglia J (1995) Distinct patterns of IFN sensitivity observed in cells infected with vaccinia K3L- and E3L-mutant viruses. Virology 210:254-263

Behar SM, Porcelli SA (2007) CD1-restricted T cells in host defense to infectious diseases. Curr Top Microbiol Immunol 314:215-250

Behncke H, Stohr AC, Heckers KO et al (2013) Mass-mortality in green striped tree dragons (Japalura splendida) associated with multiple viral infections. Vet Rec 173:248

Bendelac A, Lantz O, Quimby ME et al (1995) CD1 recognition by mouse NK1+ T lymphocytes. Science 268:863-865

Bendelac A, Hunziker RD, Lantz O (1996) Increased interleukin 4 and immunoglobulin E production in transgenic mice overexpressing NK1 T cells. J Exp Med 184:1285-1293

Bendelac A, Rivera MN, Park SH et al (1997) Mouse CD1-specific NK1 T cells: development, specificity, and function. Annu Rev Immunol 15:535-562

Besch R, Poeck H, Hohenauer T et al (2009) Proapoptotic signaling induced by RIG-I and MDA-5 results in type I interferon-independent apoptosis in human melanoma cells. J Clin Invest 119:2399-2411

Blomberg B, Bernard CC, Du Pasquier L (1980) In vitro evidence for T-B lymphocyte collaboration in the clawed toad, Xenopus. Eur J Immunol 10:869-876

Bollinger TK, Mao J, Schock D et al (1999) Pathology, isolation, and preliminary molecular characterization of a novel iridovirus from tiger salamanders in Saskatchewan. J Wildl Dis 35: 413-429

Brunner JL, Schock DM, Davidson EW et al (2004) Intraspective reservoires: complex life hoistory and the persistance of a lethal ranavirus. Ecology 85:560-566

Caipang CM, Hirono I, Aoki T (2003) In vitro inhibition of fish rhabdoviruses by Japanese flounder, Paralichthys olivaceus Mx. Virology 317:373-382

Caipang CM, Takano T, Hirono I et al (2006) Genetic vaccines protect red seabream, Pagrus major, upon challenge with red seabream iridovirus (RSIV). Fish Shellfish Immunol 21:130-138

Cano I, Alonso MC, Garcia-Rosado E et al (2006) Detection of lymphocystis disease virus (LCDV) in asymptomatic cultured gilt-head seabream (Sparus aurata, L.) using an immunoblot technique. Vet Microbiol 113:137-141 
Cano I, Ferro P, Alonso MC et al (2009) Application of in situ detection techniques to determine the systemic condition of lymphocystis disease virus infection in cultured gilt-head seabream, Sparus aurata L. J Fish Dis 32:143-150

Carey C, Cohen N, Rollins-Smith L (1999) Amphibian declines: an immunological perspective. Dev Comp Immunol 23:459-472

Chang M, Nie P, Collet B et al (2009) Identification of an additional two-cysteine containing type I interferon in rainbow trout Oncorhynchus mykiss provides evidence of a major gene duplication event within this gene family in teleosts. Immunogenetics 61:315-325

Chao CB, Chen CY, Lai YY et al (2004) Histological, ultrastructural, and in situ hybridization study on enlarged cells in grouper Epinephelus hybrids infected by grouper iridovirus in Taiwan (TGIV). Dis Aquat Organ 58:127-142

Chen G, Robert J (2011) Antiviral immunity in amphibians. Viruses 3:2065-2086

Chen G, Ward BM, Yu KH et al (2011) Improved knockout methodology reveals that frog virus 3 mutants lacking either the $18 \mathrm{~K}$ immediate-early gene or the truncated vIF-2alpha gene are defective for replication and growth in vivo. J Virol 85:11131-11138

Cheng K, Escalon BL, Robert J et al (2014) Differential transcription of fathead minnow immunerelated genes following infection with frog virus 3 , an emerging pathogen of ectothermic vertebrates. Virology 456-457:77-86

Chinchar VG, Wang J, Murti G et al (2001) Inactivation of frog virus 3 and channel catfish virus by esculentin-2P and ranatuerin-2P, two antimicrobial peptides isolated from frog skin. Virology 288:351-357

Chinchar VG, Bryan L, Wang J et al (2003) Induction of apoptosis in frog virus 3-infected cells. Virology 306:303-312

Chinchar VG, Hyatt A, Miyazaki T et al (2009) Family Iridoviridae: poor viral relations no longer. Curr Top Microbiol Immunol 328:123-170

Choi HJ, Xu H, Geng Y et al (2008) Bacterial infection alters the kinetics and function of iNKT cell responses. J Leukoc Biol 84:1462-1471

Chung SW, Arnott JA, Yang Y et al (2003) Presence of prepackaged mRNA in virions of DNA adenovirus. J Biol Chem 278:50635-50640

Cohen NR, Garg S, Brenner MB (2009) Antigen presentation by CD1 lipids, T cells, and NKT cells in microbial immunity. Adv Immunol 102:1-94

Coiras M, Lopez-Huertas MR, Perez-Olmeda M et al (2009) Understanding HIV-1 latency provides clues for the eradication of long-term reservoirs. Nat Rev Microbiol 7:798-812

Cotter JD, Storfer A, Page RB et al (2008) Transcriptional response of Mexican axolotls to Ambystoma tigrinum virus (ATV) infection. BMC Genomics 9:493

De Jesús Andino F, Chen G, Li Z et al (2012) Susceptibility of Xenopus laevis tadpoles to infection by the ranavirus Frog-Virus 3 correlates with a reduced and delayed innate immune response in comparison with adult frogs. Virology 432:435-443

Diener TO, Hammond RW, Black T et al (1993) Mechanism of viroid pathogenesis: differential activation of the interferon-induced, double-stranded RNA-activated, M(r) 68,000 protein kinase by viroid strains of varying pathogenicity. Biochimie 75:533-538

Du Pasquier L, Schwager J, Flajnik MF (1989) The immune system of Xenopus. Annu Rev Immunol 7:251-275

Du Pasquier L, Robert J, Courtet M et al (2000) B-cell development in the amphibian Xenopus. Immunol Rev 175:201-213

Duffus ALJ, Nichols RA, Garner TWJ (2013) Investigations into the life history stages of the common frog (Rana temporaria) affected by an amphibian ranavirus in the United Kingdom. Herpetol Rev 44:260-263

Eaton HE, Metcalf J, Penny E et al (2007) Comparative genomic analysis of the family Iridoviridae: re-annotating and defining the core set of iridovirus genes. Virol J 4:11

Edholm ES, Albertorio Saez LM, Gill AL et al (2013) Nonclassical MHC class I-dependent invariant $\mathrm{T}$ cells are evolutionarily conserved and prominent from early development in amphibians. Proc Natl Acad Sci U S A 110:14342-14347 
Elharrar M, Hirth C, Blanc J et al (1973) Pathogenesis of the toxic hepatitis of mice provoked by FV 3 (frog virus 3): inhibition of liver macromolecular synthesis (author's transl). Biochim Biophys Acta 319:91-102

Fernandez-Trujillo MA, Garcia-Rosado E, Alonso MC et al (2013) Mx1, Mx2 and Mx3 proteins from the gilthead seabream (Sparus aurata) show in vitro antiviral activity against RNA and DNA viruses. Mol Immunol 56:630-636

Finlay BB, McFadden G (2006) Anti-immunology: evasion of the host immune system by bacterial and viral pathogens. Cell 124:767-782

Flajnik MF, Kasahara M (2001) Comparative genomics of the MHC: glimpses into the evolution of the adaptive immune system. Immunity 15:351-362

Fullerton JN, O'Brien AJ, Gilroy DW (2013) Pathways mediating resolution of inflammation: when enough is too much. J Pathol 231:8-20

Gantress J, Maniero GD, Cohen N et al (2003) Development and characterization of a model system to study amphibian immune responses to iridoviruses. Virology 311:254-262

Gendrault JL, Steffan AM, Bingen A et al (1981) Penetration and uncoating of frog virus 3 (FV3) in cultured rat Kupffer cells. Virology 112:375-384

Glaser R, Litsky ML, Padgett DA et al (2006) EBV-encoded dUTPase induces immune dysregulation: implications for the pathophysiology of EBV-associated disease. Virology 346:205-218

Goodenow MM, Rose SL, Tuttle DL et al (2003) HIV-1 fitness and macrophages. J Leukoc Biol 74:657-666

Gousset K, Ablan SD, Coren LV et al (2008) Real-time visualization of HIV-1 GAG trafficking in infected macrophages. PLoS Pathog 4:e1000015

Goyos A, Ohta Y, Guselnikov S et al (2009) Novel nonclassical MHC class Ib genes associated with CD8 T cell development and thymic tumors. Mol Immunol 46:1775-1786

Goyos A, Sowa J, Ohta Y et al (2011) Remarkable conservation of distinct nonclassical MHC class I lineages in divergent amphibian species. J Immunol 186:372-381

Gray MJ, Miller DL (2013) Rise of ranavirus: an emerging pathogen threatens ectothermic vertebrates. Wildl Professional 7:51-55

Grayfer L, Garcia EG, Belosevic M (2010) Comparison of macrophage antimicrobial responses induced by type II interferons of the goldfish (Carassius auratus L.). J Biol Chem 285: 23537-23547

Grayfer L, De Jesús Andino F, Robert J (2014) The amphibian (Xenopus laevis) type I interferon response to Frog Virus 3: new insight into ranavirus pathogenicity. J Virol 88(10):5766-5777

Groot F, Welsch S, Sattentau QJ (2008) Efficient HIV-1 transmission from macrophages to T cells across transient virological synapses. Blood 111:4660-4663

Gut JP, Anton M, Bingen A et al (1981) Frog virus 3 induces a fatal hepatitis in rats. Lab Invest 45:218-228

Hagmann W, Steffan AM, Kirn A et al (1987) Leukotrienes as mediators in frog virus 3-induced hepatitis in rats. Hepatology 7:732-736

Haislip NA, Gray MJ, Hoverman JT et al (2011) Development and disease: how susceptibility to an emerging pathogen changes through anuran development. PLoS One 6:e22307

Hervas-Stubbs S, Perez-Gracia JL, Rouzaut A et al (2011) Direct effects of type I interferons on cells of the immune system. Clin Cancer Res 17:2619-2627

Holopainen R, Tapiovaara H, Honkanen J (2012) Expression analysis of immune response genes in fish epithelial cells following ranavirus infection. Fish Shellfish Immunol 32:1095-1105

Horton JD, Horton TL, Dzialo R et al (1998) T-cell and natural killer cell development in thymectomized Xenopus. Immunol Rev 166:245-258

Hoverman JT, Gray MJ, Miller DL (2010) Anuran susceptibilities to ranaviruses: role of species identity, exposure route, and a novel virus isolate. Dis Aquat Organ 89:97-107

Hsu E (1998) Mutation, selection, and memory in B lymphocytes of exothermic vertebrates. Immunol Rev 162:25-36

Hyatt AD, Williamson M, Coupar BE et al (2002) First identification of a ranavirus from green pythons (Chondropython viridis). J Wildl Dis 38:239-252 
Jancovich JK, Jacobs BL (2011) Innate immune evasion mediated by the Ambystoma tigrinum virus eukaryotic translation initiation factor 2alpha homologue. J Virol 85:5061-5069

Joerink M, Forlenza M, Ribeiro CM et al (2006a) Differential macrophage polarisation during parasitic infections in common carp (Cyprinus carpio L.). Fish Shellfish Immunol 21:561-571

Joerink M, Ribeiro CM, Stet RJ et al (2006b) Head kidney-derived macrophages of common carp (Cyprinus carpio L.) show plasticity and functional polarization upon differential stimulation. J Immunol 177:61-69

Joerink M, Savelkoul HF, Wiegertjes GF (2006c) Evolutionary conservation of alternative activation of macrophages: structural and functional characterization of arginase 1 and 2 in carp (Cyprinus carpio L.). Mol Immunol 43:1116-1128

Johnston JB, McFadden G (2003) Poxvirus immunomodulatory strategies: current perspectives. J Virol 77:6093-6100

Jurgens JB, Gartland LA, Du Pasquier L et al (1995) Identification of a candidate CD5 homologue in the amphibian Xenopus laevis. J Immunol 155:4218-4223

Katze MG (1992) The war against the interferon-induced dsRNA-activated protein kinase: can viruses win? J Interferon Res 12:241-248

Kawai T, Akira S (2009) The roles of TLRs, RLRs and NLRs in pathogen recognition. Int Immunol 21:317-337

Kawai T, Akira S (2010) The role of pattern-recognition receptors in innate immunity: update on Toll-like receptors. Nat Immunol 11:373-384

Kirn A, Gut JP, Elharrar M (1972) [FV3 (Frog Virus 3) toxicity for the mouse]. Nouv Presse Med $1: 1943$

Kirn A, Steffan AM, Bingen A (1980) Inhibition of erythrophagocytosis by cultured rat Kupffer cells infected with frog virus 3. J Reticuloendothel Soc 28:381-388

Kirn A, Bingen A, Steffan AM et al (1982) Endocytic capacities of Kupffer cells isolated from the human adult liver. Hepatology 2:216-222

Kochs G, Reichelt M, Danino D et al (2005) Assay and functional analysis of dynamin-like Mx proteins. Methods Enzymol 404:632-643

Kotenko SV (2011) IFN-lambdas. Curr Opin Immunol 23:583-590

Krieg AM (2002) CpG motifs in bacterial DNA and their immune effects. Annu Rev Immunol 20:709-760

Krug LT, Pozharskaya VP, Yu Y et al (2004) Inhibition of infection and replication of human herpesvirus 8 in microvascular endothelial cells by alpha interferon and phosphonoformic acid. J Virol 78:8359-8371

Landsberg JH, Kiryu Y, Tabuchi M et al (2013) Co-infection by alveolate parasites and frog virus 3-like ranavirus during an amphibian larval mortality event in Florida, USA. Dis Aquat Organ 105:89-99

Langland JO, Jacobs BL (2002) The role of the PKR-inhibitory genes, E3L and K3L, in determining vaccinia virus host range. Virology 299:133-141

Langland JO, Kash JC, Carter V et al (2006) Suppression of proinflammatory signal transduction and gene expression by the dual nucleic acid binding domains of the vaccinia virus E3L proteins. J Virol 80:10083-10095

Le Bourhis L, Martin E, Peguillet I et al (2010) Antimicrobial activity of mucosal-associated invariant T cells. Nat Immunol 11:701-708

Leibovitz L (1980) Lymphocystis disease. J Am Vet Med Assoc 176:202

Lester K, Hall M, Urquhart K et al (2012) Development of an in vitro system to measure the sensitivity to the antiviral Mx protein of fish viruses. J Virol Methods 182:1-8

Levraud JP, Boudinot P, Colin I et al (2007) Identification of the zebrafish IFN receptor: implications for the origin of the vertebrate IFN system. J Immunol 178:4385-4394

Li Z, Strunk JJ, Lamken P et al (2008) The EM structure of a type I interferon-receptor complex reveals a novel mechanism for cytokine signaling. J Mol Biol 377:715-724

Li Z, Xu X, Huang L et al (2010) Administration of recombinant IFN1 protects zebrafish (Danio rerio) from ISKNV infection. Fish Shellfish Immunol 29:399-406 
Long S, Wilson M, Bengten E et al (2004) Identification of a cDNA encoding channel catfish interferon. Dev Comp Immunol 28:97-111

Lopez C, Aubertin AM, Tondre L et al (1986) Thermosensitivity of frog virus 3 genome expression: defect in early transcripti. Virology 152:365-374

Lopez-Munoz A, Roca FJ, Meseguer J et al (2009) New insights into the evolution of IFNs: zebrafish group II IFNs induce a rapid and transient expression of IFN-dependent genes and display powerful antiviral activities. J Immunol 182:3440-3449

Lutfalla G, Roest Crollius H, Stange-Thomann N et al (2003) Comparative genomic analysis reveals independent expansion of a lineage-specific gene family in vertebrates: the class II cytokine receptors and their ligands in mammals and fish. BMC Genomics 4:29

Majji S, LaPatra S, Long SM et al (2006) Rana catesbeiana virus Z (RCV-Z): a novel pathogenic ranavirus. Dis Aquat Organ 73:1-11

Maniero GD, Morales H, Gantress J et al (2006) Generation of a long-lasting, protective, and neutralizing antibody response to the ranavirus FV3 by the frog Xenopus. Dev Comp Immunol 30:649-657

Matsuda JL, Gapin L (2005) Developmental program of mouse Valpha14i NKT cells. Curr Opin Immunol 17:122-130

Meylan E, Curran J, Hofmann K et al (2005) Cardif is an adaptor protein in the RIG-I antiviral pathway and is targeted by hepatitis C virus. Nature 437:1167-1172

Miller D, Gray M, Storfer A (2011) Ecopathology of ranaviruses infecting amphibians. Viruses 3:2351-2373

Morales HD, Robert J (2007) Characterization of primary and memory CD8 T-cell responses against ranavirus (FV3) in Xenopus laevis. J Virol 81:2240-2248

Morales HD, Abramowitz L, Gertz J et al (2010) Innate immune responses and permissiveness to ranavirus infection of peritoneal leukocytes in the frog Xenopus laevis. J Virol 84:4912-4922

Nahrendorf M, Swirski FK, Aikawa E et al (2007) The healing myocardium sequentially mobilizes two monocyte subsets with divergent and complementary functions. J Exp Med 204: 3037-3047

Nakajima K, Kunita J (2005) [Red sea bream iridoviral disease]. Uirusu 55:115-125

Nakajima K, Maeno Y, Honda A et al (1999) Effectiveness of a vaccine against red sea bream iridoviral disease in a field trial test. Dis Aquat Organ 36:73-75

Nishikawa A, Murata E, Akita M et al (1998) Roles of macrophages in programmed cell death and remodeling of tail and body muscle of Xenopus laevis during metamorphosis. Histochem Cell Biol 109:11-17

Oliveros M, Garcia-Escudero R, Alejo A et al (1999) African swine fever virus dUTPase is a highly specific enzyme required for efficient replication in swine macrophages. J Virol 73: 8934-8943

Panniers R, Rowlands AG, Henshaw EC (1988) The effect of Mg2+ and guanine nucleotide exchange factor on the binding of guanine nucleotides to eukaryotic initiation factor 2. J Biol Chem 263:5519-5525

Pham PH, Lai YS, Lee FF et al (2012) Differential viral propagation and induction of apoptosis by grouper iridovirus (GIV) in cell lines from three non-host species. Virus Res 167:16-25

Proud CG (1995) PKR: a new name and new roles. Trends Biochem Sci 20:241-246

Qi Z, Nie P, Secombes CJ et al (2010) Intron-containing type I and type III IFN coexist in amphibians: refuting the concept that a retroposition event gave rise to type I IFNs. J Immunol 184: 5038-5046

Raghow R, Granoff A (1979) Macromolecular synthesis in cells infected by frog virus 3. X. Inhibition of cellular protein synthesis by heat-inactivated virus. Virology 98:319-327

Reeve BC, Crespi EJ, Whipps CM et al (2013) Natural stressors and ranavirus susceptibility in larval wood frogs (Rana sylvatica). Ecohealth 10:190-200

Robert J, Ohta Y (2009) Comparative and developmental study of the immune system in Xenopus. Dev Dyn 238:1249-1270 
Robert J, Morales H, Buck W et al (2005) Adaptive immunity and histopathology in frog virus 3-infected Xenopus. Virology 332:667-675

Robert J, Abramowitz L, Gantress J et al (2007) Xenopus laevis: a possible vector of Ranavirus infection? J Wildl Dis 43:645-652

Robert J, George E, De Jesús Andino F et al (2011) Waterborne infectivity of the Ranavirus frog virus 3 in Xenopus laevis. Virology 417:410-417

Robertsen B (2006) The interferon system of teleost fish. Fish Shellfish Immunol 20:172-191

Robertsen B, Bergan V, Rokenes T et al (2003) Atlantic salmon interferon genes: cloning, sequence analysis, expression, and biological activity. J Interferon Cytokine Res 23:601-612

Rollins-Smith LA (2009) The role of amphibian antimicrobial peptides in protection of amphibians from pathogens linked to global amphibian declines. Biochim Biophys Acta 1788: 1593-1599

Rollins-Smith LA, Reinert LK, O’Leary CJ et al (2005) Antimicrobial peptide defenses in amphibian skin. Integr Comp Biol 45:137-142

Rothenburg S, Chinchar VG, Dever TE (2011) Characterization of a ranavirus inhibitor of the antiviral protein kinase PKR. BMC Microbiol 11:56

Rowlands AG, Panniers R, Henshaw EC (1988) The catalytic mechanism of guanine nucleotide exchange factor action and competitive inhibition by phosphorylated eukaryotic initiation factor 2. J Biol Chem 263:5526-5533

Sadler AJ, Williams BR (2008) Interferon-inducible antiviral effectors. Nat Rev Immunol 8:559-568

Samuel CE (2001) Antiviral actions of interferons. Clin Microbiol Rev 14:778-809, Table of contents

Seet BT, Johnston JB, Brunetti CR et al (2003) Poxviruses and immune evasion. Annu Rev Immunol 21:377-423

Siwicki AK, Pozet F, Morand M et al (1999) Effects of iridovirus-like agent on the cell-mediated immunity in sheatfish (Silurus glanis) — an in vitro study. Virus Res 63:115-119

Sroller V, Kutinova L, Nemeckova S et al (1998) Effect of 3-beta-hydroxysteroid dehydrogenase gene deletion on virulence and immunogenicity of different vaccinia viruses and their recombinants. Arch Virol 143:1311-1320

Sun B, Robertsen B, Wang Z et al (2009) Identification of an Atlantic salmon IFN multigene cluster encoding three IFN subtypes with very different expression properties. Dev Comp Immunol 33:547-558

Sutton WB, Gray MJ, Hardman RH et al (2014) High susceptibility of the endangered dusky gopher frog to ranavirus. Dis Aquat Organ 112(1):9-16

Svingerud T, Solstad T, Sun B et al (2012) Atlantic salmon type I IFN subtypes show differences in antiviral activity and cell-dependent expression: evidence for high IFNb/IFNc-producing cells in fish lymphoid tissues. J Immunol 189:5912-5923

Toth AM, Zhang P, Das S et al (2006) Interferon action and the double-stranded RNA-dependent enzymes ADAR1 adenosine deaminase and PKR protein kinase. Prog Nucleic Acid Res Mol Biol 81:369-434

Trobridge GD, Chiou PP, Leong JA (1997) Cloning of the rainbow trout (Oncorhynchus mykiss) $\mathrm{Mx} 2$ and Mx3 cDNAs and characterization of trout Mx protein expression in salmon cells. J Virol 71:5304-5311

Turner RJ, Manning MJ (1974) Thymic dependence of amphibian antibody responses. Eur J Immunol 4:343-346

Wiegertjes GF, Forlenza M (2010) Nitrosative stress during infection-induced inflammation in fish: lessons from a host-parasite infection model. Curr Pharm Des 16:4194-4202

Wu YC, Chi SC (2007) Cloning and analysis of antiviral activity of a barramundi (Lates calcarifer) Mx gene. Fish Shellfish Immunol 23:97-108

Wu MS, Chen CW, Liu YC et al (2012) Transcriptional analysis of orange-spotted grouper reacting to experimental grouper iridovirus infection. Dev Comp Immunol 37:233-242 
Yang SJ, Xiao XH, Xu YG et al (2012) Induction of antimicrobial peptides from Rana dybowskii under Rana grylio virus stress, and bioactivity analysis. Can J Microbiol 58:848-855

Zhang F, Romano PR, Nagamura-Inoue T et al (2001) Binding of double-stranded RNA to protein kinase PKR is required for dimerization and promotes critical autophosphorylation events in the activation loop. J Biol Chem 276:24946-24958

Zhao C, Zhang H, Wong WC et al (2009) Identification of novel functional differences in monocyte subsets using proteomic and transcriptomic methods. J Proteome Res 8:4028-4038

Zhu R, Wang J, Lei XY et al (2013) Evidence for Paralichthys olivaceus IFITM1 antiviral effect by impeding viral entry into target cells. Fish Shellfish Immunol 35:918-926

Ziegler-Heitbrock L (2007) The CD14+ CD16+ blood monocytes: their role in infection and inflammation. J Leukoc Biol 81:584-592

Zilberg D, Grizzle JM, Plumb JA (2000) Preliminary description of lesions in juvenile largemouth bass injected with largemouth bass virus. Dis Aquat Organ 39:143-146

Zou J, Secombes CJ (2011) Teleost fish interferons and their role in immunity. Dev Comp Immunol 35:1376-1387

Zou J, Tafalla C, Truckle J et al (2007) Identification of a second group of type I IFNs in fish sheds light on IFN evolution in vertebrates. J Immunol 179:3859-3871 


\title{
Comparative Pathology of Ranaviruses and Diagnostic Techniques
}

\author{
Debra L. Miller, Allan P. Pessier, Paul Hick, and Richard J. Whittington
}

\section{Ranaviral Disease}

\subsection{Introduction}

Ranaviruses were detected and diagnosed as a disease agent in amphibians in the 1960s, and in reptiles and fish in the 1980s (Duffus et al. 2015). Since these initial cases, ranaviruses have been linked to numerous epizootic mortality events in these three classes of lower vertebrate animals (Duffus et al. 2015). Although long-term population data are generally lacking, there is evidence that ranaviruses can cause population declines in amphibians (Teacher et al. 2010; Beebee 2012; Earl and Gray 2014; Price et al. 2014). Further, the nearly complete loss of entire age classes of fish and amphibians due to ranavirus outbreaks have been reported (Petranka et al. 2003; Todd-Thompson 2010; Waltzek et al. 2014; Wheelwright et al. 2014), and some species of global conservation concern are highly susceptible (Geng et al. 2010; Sutton et al. 2014a). More recently, the potential economic impact of ranaviruses in farmed fish and amphibians (Mazzoni et al. 2009; Waltzek et al. 2014), and on recreational fisheries (Grizzle and Brunner 2003) has been recognized. Given

\footnotetext{
D.L. Miller $(\bowtie)$

Center for Wildlife Health and Department of Biomedical and Diagnostic Sciences, University of Tennessee, Knoxville, TN 37996, USA

e-mail: dmille42@utk.edu

A.P. Pessier

Institution for Conservation Research, San Diego Zoo, San Diego, CA 92112, USA

e-mail: APessier@sandiegozoo.org

P. Hick • R.J. Whittington

Faculty of Veterinary Science, University of Sydney, Sydney, NSW, Australia

e-mail: paul.hick@sydney.edu.au; richard.whittington@sydney.edu.au
} 
these concerns, ranaviruses that infect amphibians and Epizootic hematopoietic necrosis virus (EHNV) are listed as notifiable agents by the World Organization for Animal Health (OIE, Schloegel et al. 2010).

Despite the global awareness of ranaviruses, the distribution of ranaviruses and their effects on host populations and international commerce remain poorly understood. Further, there is limited information on the mechanisms that affect hostranavirus interactions and factors that lead to mortality events (Gray et al. 2009). Various field studies and controlled experiments are expanding our knowledge of ranaviruses (Duffus et al. 2015; Brunner et al. 2015; Jancovich et al. 2015b); however, more research is needed. Properly designed studies (Gray et al. 2015) are a first step to investigating hypotheses associated with ranavirus emergence. Use of appropriate diagnostic techniques is key to identifying ranavirus infections and determining the effects of infection on host species. Understanding the differential diagnoses for ranaviral disease is important, and combining infection data with pathological and environmental information is essential to confirm that ranavirus is the etiologic disease agent.

In this chapter, we begin with an overview of the gross and microscopic lesions associated with ranaviral disease followed by a discussion of the current diagnostic tests in use by research and veterinary diagnostic laboratories worldwide. We point out the limitations of certain diagnostic techniques, and identify needed areas of improvement. Finally, we briefly discuss research into treatment and vaccine development for ranaviruses.

\subsection{Ranaviral Disease Pathology}

\subsubsection{Field and Clinical Findings}

In amphibians, outbreaks of ranaviral disease are most often observed in larvae and recently metamorphosed animals (Green et al. 2002; Docherty et al. 2003; Balseiro et al. 2009, 2010); however, outbreaks that include adult animals are increasingly recognized (Cunningham et al. 2007; Cheng et al. 2014). Moreover, Earl and Gray (2014) demonstrated that ranavirus-associated mortality of larvae or metamorphs was sufficient to cause population declines in highly susceptible species. Researchers have demonstrated a strong correlation between infection prevalence and mortality in laboratory experiments with Frog Virus 3 (FV3)-like ranaviruses (see Haislip et al. 2011; Hoverman et al. 2011; Brenes et al. 2014a); thus, high infection prevalence during field surveillance may be an indicator of an impending die-off (Gray et al. 2015).

Mortality events often present as sudden and massive deaths across multiple species (Todd-Thompson 2010; Wheelwright et al. 2014). Deaths may continue for weeks, with later deaths due to individuals succumbing to secondary bacterial or fungal infections (Jancovich et al. 1997; Cunningham et al. 2007; Miller et al. 2008; Cheng et al. 2014). Field signs vary but lethargy is commonly reported in all classes 
(Table 1). Chelonians can have additional signs of respiratory distress (Ruder et al. 2010; Farnsworth and Seigel 2013). Prior to death, diseased amphibians and fish may exhibit erratic swimming, loss of buoyancy, and loss of righting reflex (Mao et al. 1999; Bollinger et al. 1999; Zilberg et al. 2000; Geng et al. 2010; Miller et al. 2011). Recently, a vestibular syndrome has been observed in cultured adult bullfrogs (Lithobates catesbeianus) in Brazil (R. Mazzoni, CRMV-GO, Brazil, personal communication), and may explain these changes in coordination. Future investigation of the histologic changes within the brain of animals displaying a lack of coordination is needed.

\subsubsection{Gross Pathology}

The appearance of disease in individual animals reflects the systemic distribution of the virus and associated host response. Clinical disease is typically acute and can affect a high proportion of the population. In wild populations, the acute course of disease and rapid mortality might prevent detection of the disease event (Gray et al. 2015), or outbreaks might present as a large number of dead individuals. Clinically affected individuals are generally preferred to use for testing because they are most likely to yield a diagnosis. Affected individuals present with hemorrhages, edema, and necrosis as the most common gross lesions; however, the presentation of these

Table 1 Examples of field (clinical) signs and gross changes that can be observed in individuals with ranaviral disease

\begin{tabular}{l|l}
\hline Class & Lesion \\
\hline Amphibian & $\begin{array}{l}\text { Loss of buoyancy; erratic swimming; anorexia; swelling (edema) of the body, } \\
\text { head, legs, and internal soft tissues; external hemorrhages (especially around } \\
\text { the vent, periocular, gular region, legs); occasional internal hemorrhages } \\
\text { (especially pronephros, liver, spleen) }\end{array}$ \\
\hline Anuran adults & $\begin{array}{l}\text { Lethargy; anorexia; loss of buoyancy and erratic swimming (aquatic species); } \\
\text { swelling (edema) of legs, feet, body, and internal soft tissues; skin ulcers; } \\
\text { dermal, oral, and internal hemorrhages (ecchymotic, petechial); friable } \\
\text { (necrotic) organs }\end{array}$ \\
\hline Caudate adults & $\begin{array}{l}\text { Lethargy; anorexia; loss of buoyancy and erratic swimming (aquatic species); } \\
\text { hemorrhages (especially on tail and plantar surfaces of feet); swelling } \\
\text { (edema); skin ulcers; internal hemorrhages (ecchymotic, petechial); friable } \\
\text { (necrotic) organs; necrosis of extremities (Chinese Giant Salamanders) }\end{array}$ \\
\hline Fish & $\begin{array}{l}\text { Loss of buoyancy; erratic swimming; anorexia; red swollen gills; } \\
\text { hemorrhages (especially periocular, fat bodies, swim bladder); overinflated } \\
\text { swim bladder; friable (necrotic) organs; multiple pale foci in liver }\end{array}$ \\
\hline Chelonians & $\begin{array}{l}\text { Respiratory difficulty; anorexia; oral necrotic plaques; swelling (edema or } \\
\text { rarely necrosis) of head, neck, legs, internal soft tissues, periocular; skin } \\
\text { ulcers; friable (necrotic) organs; hemorrhages (especially internal) }\end{array}$ \\
\hline Lizards & $\begin{array}{l}\text { Lethargy; anorexia; oral necrotic plaques; skin ulcers; friable (necrotic) } \\
\text { organs; occasional internal hemorrhages and edema }\end{array}$ \\
\hline Snakes & Lethargy; anorexia; oral and nasal ulcers \\
\hline
\end{tabular}


changes can vary depending on the species affected and whether exposure to environmental stressors or other pathogens also occurs (Table 1).

\section{Amphibians}

Hemorrhages (ecchymotic and petechial) and erythema are common in the skin of anurans and caudates (Fig. 1a, b). Hemorrhages are most often present on the ventral surfaces near the vent, rear legs, and gular regions, but can also be observed around the eyes, ear drum, tongue, tail, and feet (Balseiro et al. 2009; Cheng et al. 2014; Cunningham et al. 2007; Docherty et al. 2003; Geng et al. 2010; Kik et al. 2011; Meng et al. 2014; Sutton et al. 2014a). Raised skin plaques or polyps have been described in tiger salamanders (Ambystoma tigrinum) and Chinese giant salamanders (Jancovich et al. 1997; Bollinger et al. 1999; Geng et al. 2010). Other
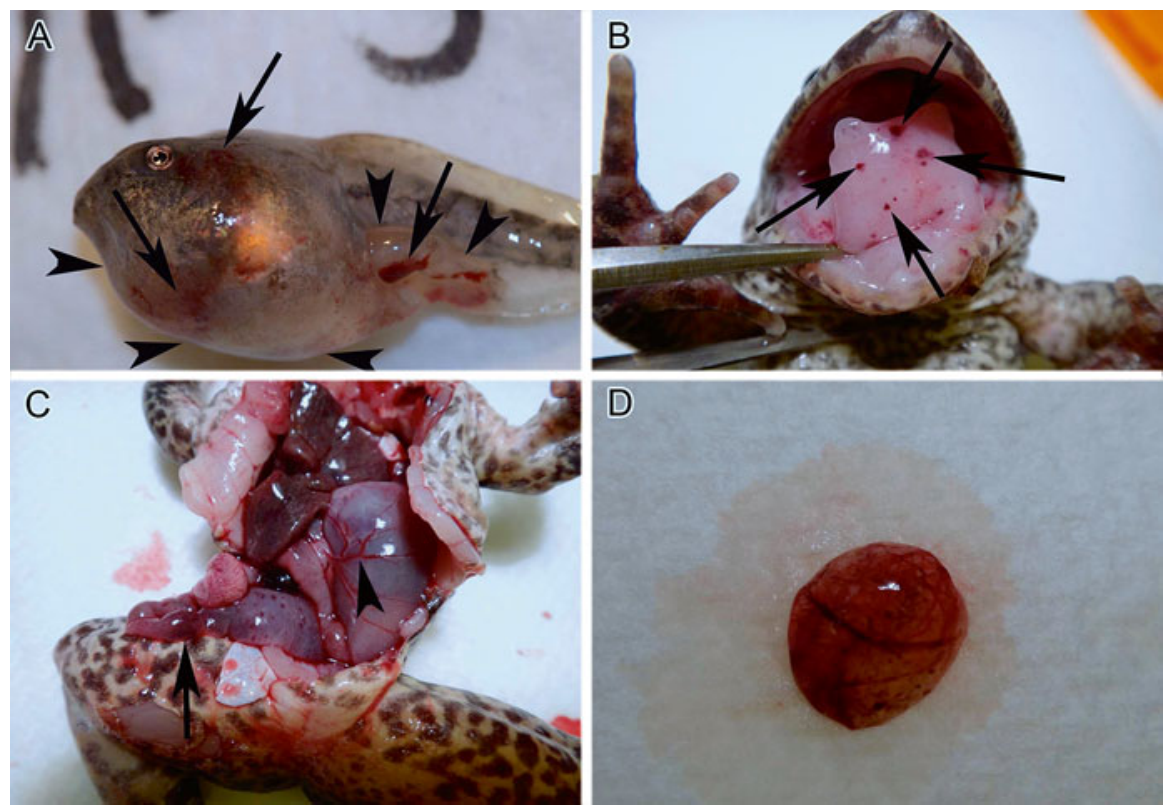

Fig. 1 Gross lesions seen in amphibians with ranaviral disease. (a) Hemorrhages (arrows) and edema (arrowheads) in a wood frog (Lithobates sylvaticus) tadpole experimentally challenged with an FV3-like ranavirus. (b) Tongue hemorrhages (arrows) in a dusky gopher frog (Lithobates sevosus) experimentally challenged with an FV3-like ranavirus. (c) Intestinal hemorrhage (arrow) and congested blood vessels (arrowhead) in a dusky gopher frog experimentally challenged with an FV3-like ranavirus. (d) Tan friable and hemorrhagic spleen of a dusky gopher frog experimentally challenged with an FV3-like ranavirus 
findings in the skin of anurans and caudates can include ulceration or rough discolored gray areas (e.g., Bollinger et al. 1999; Cunningham et al. 2007; Kik et al. 2011). Swelling of the legs, body, and head from accumulation of fluid (i.e., edema) within the tissues, lymph sacs, and body cavity is commonly seen in amphibians, and is especially evident in larvae (e.g., see Wolf et al. 1968; Miller et al. 2011; Meng et al. 2014).

Internally, hemorrhage and necrosis are common findings, especially in the spleen, pronephros and mesonephros (kidney), and liver (Fig. 1c, d). The cause of cell death may be associated with apoptosis or virus replication (Grayfer et al. 2015). Necrosis may present as generalized friable organs or as discrete pale foci scattered throughout an organ. Splenomegaly and hepatomegaly have also been reported (Kik et al. 2011) and may be related to congestion and hemorrhage. Intestinal hemorrhage has been seen in mortality events and in experimentally challenged anurans and caudates (Bollinger et al. 1999; Geng et al. 2010; Cheng et al. 2014; Meng et al. 2014). In Brazil, hemorrhage and necrosis are seen in the vestibular region of ranavirus-positive bullfrogs displaying vestibular syndrome (R. Mazzoni, CRMV-GO, personal communication).

In Europe, two syndromes have been described in adult common frogs (Rana temporaria), one which is systemic hemorrhages and the other which is extensive cutaneous ulcerations. Cunningham et al. (1996) first reported these syndromes from mortality events that occurred throughout Britain and were observed by members of the general public. Subsequently, both syndromes were experimentally reproduced in the common frog (Cunningham et al. 2007). Based on this result, the authors concluded that route of exposure and specific ranavirus isolate influenced the pathogenesis; however, both syndromes can develop within the same frog. The hemorrhagic syndrome is similar to pathological changes reported by Sutton et al. (2014a) in adult dusky gopher frogs (Lithobates sevosus).

\section{Fish}

In fish, multifocal, random cutaneous hemorrhages are seen (Fig. 2a; Waltzek et al. 2014), and fish may have red swollen gills (Mao et al. 1999). Internally, hemorrhages may occur in any organ including the fat bodies and swim bladder, and organs may be friable (Fig. 2b, Zilberg et al. 2000; Waltzek et al. 2014). Over-inflation of the swim bladder has been reported (Grizzle and Brunner 2003). Reddacliff and Whittington (1996) provided detailed descriptions of lesions due to EHNV in redfin perch (Perca fluviatilis) and rainbow trout (Oncorhynchus mykiss). Sick fish were dark, stopped eating, and sometimes were ataxic. Gross lesions included a swollen abdomen with swelling of the spleen and kidney; multiple pale foci were sometimes present in the liver. Zilberg et al. (2000) reported necrosis of the gastrointestinal (GI) mucosal epithelium, gills, and heart in largemouth bass (Micropterus salmoides) experimentally challenged with Santee-Cooper ranavirus. 

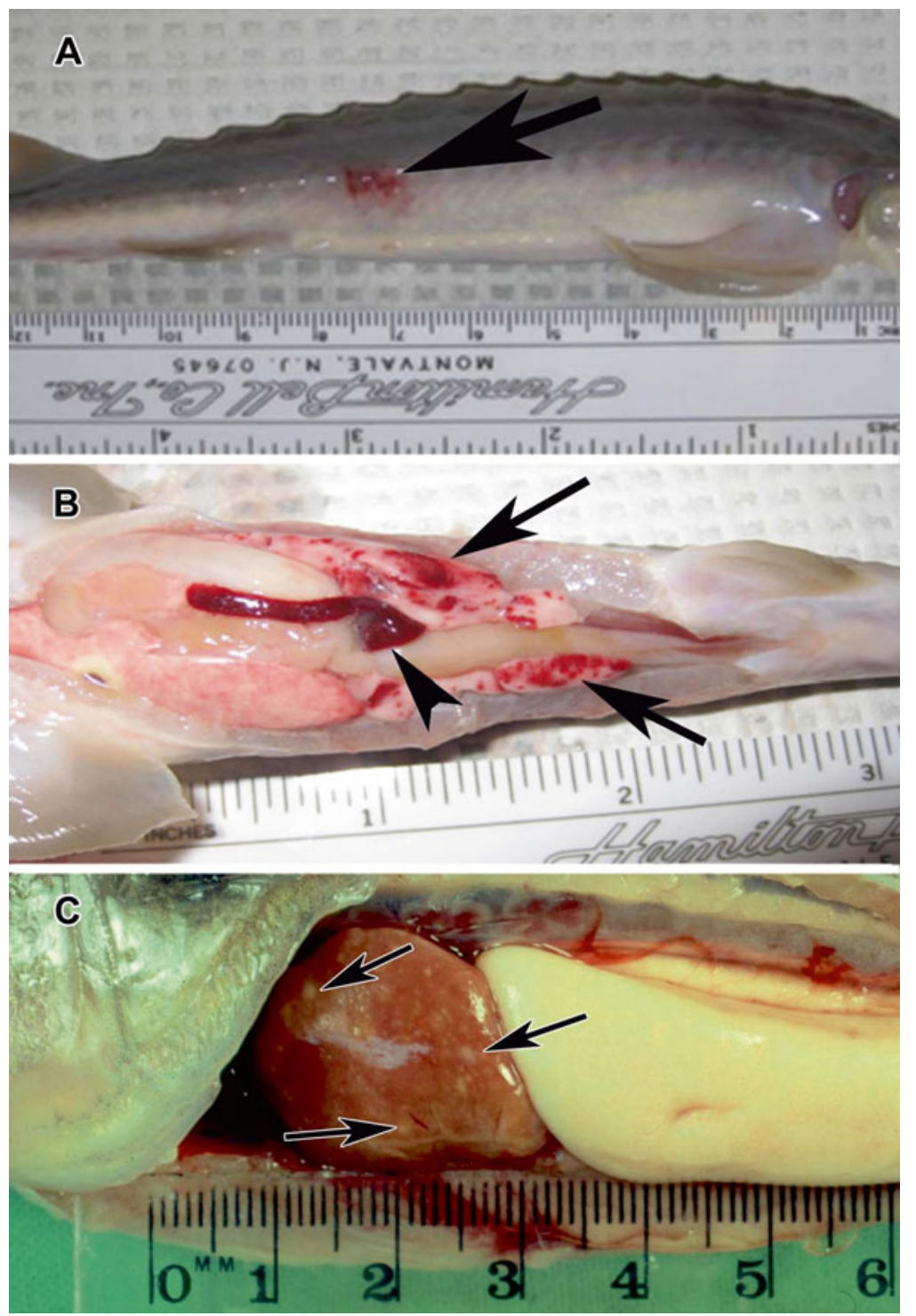

Fig. 2 Gross lesions seen in fish with ranaviral disease. (a) Pallid sturgeon (Scaphirhynchus albus) with cutaneous ecchymotic hemorrhage (arrow) due to an FV3-like ranavirus. Photo by Thomas B Waltzek, University of Florida. (b) Hemorrhage in the fat bodies (arrows) and spleen (arrowhead) of a pallid sturgeon with FV3-like ranavirus. Photo by Thomas B Waltzek, University of Florida. (c) Multifocal hepatic necrosis evidenced by areas of pale discoloration in the liver (arrows), and echymotic hemorrhage in the retroperitoneum of an adult redfin perch (Perca fluviatilis) infected with EHNV 


\section{Reptiles}

Most lesions in reptiles have been described in chelonians and include periocular swelling, ulceration and necrosis of the oral cavity, swollen head and extremities, ocular and nasal discharges, and occasional skin ulcerations (Fig. 3, e.g., Johnson et al. 2008; Ruder et al. 2010). Similarly, Hyatt et al. (2002) reported ulceration of the oral mucosa in green pythons (Chondropython viridis). In lizards, skin lesions are common and include gray discoloration, ulcerative and necrotizing dermatitis, and hyperkeratosis (Stöhr et al. 2013). Multifocal to confluent tan friable areas (necrosis) may be seen internally (especially in the GI and respiratory tracts). Occasionally, hemorrhages of the GI tract may be the only change observed in water turtles (Fig. 3d, DLM, personal observation); however, it often is unclear if this is due to secondary infections.
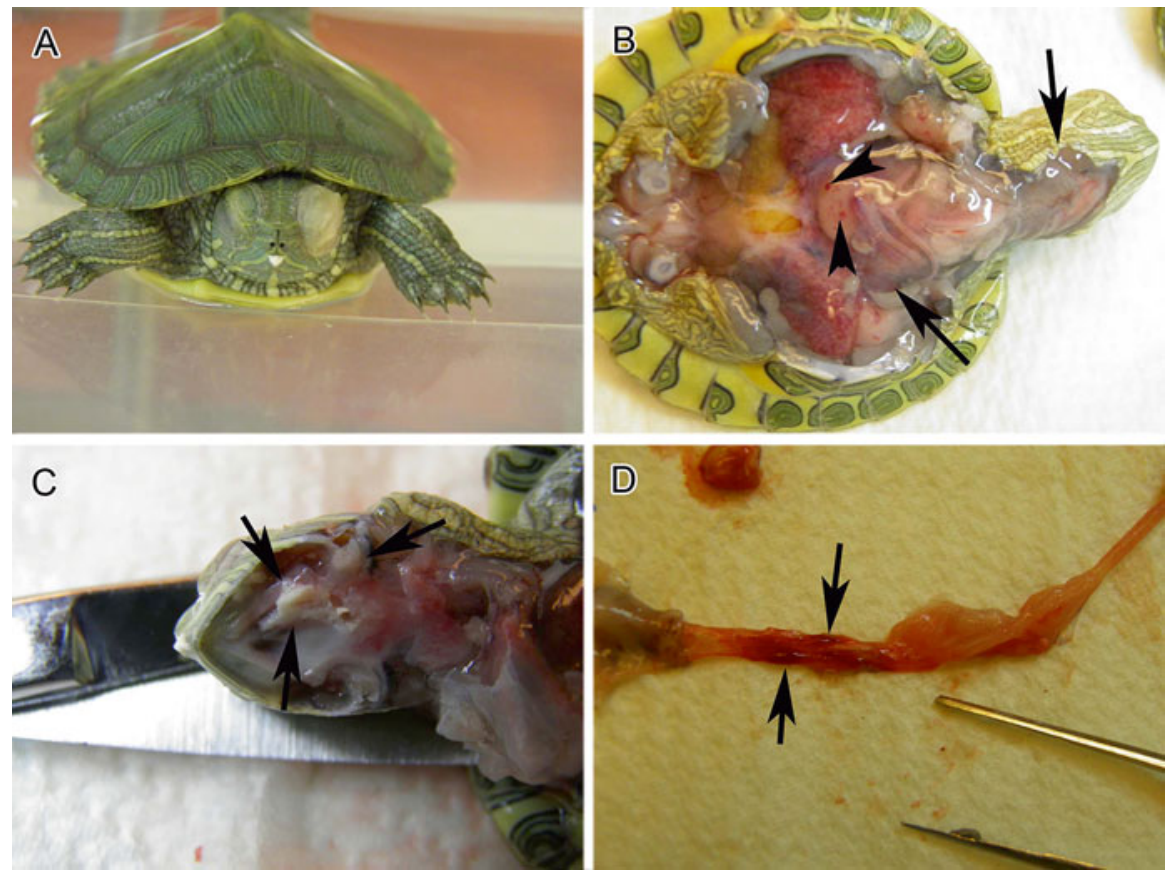

Fig. 3 Gross lesions in a red-eared slider (Trachemys scripta elegans) experimentally challenged with an FV3-like ranavirus. (a) Periocular swelling. The swelling is bilateral but more prominent around the left eye of this turtle. (b) Internal soft tissue edema (arrows) and hemorrhages (arrowheads). (c) Necrotic plaques (arrows) on the oral mucosa. (d) Hemorrhage (arrows) of the intestinal mucosa 


\subsubsection{Histopathology}

Necrosis of the hematopoietic tissues, vascular endothelium, and epithelial cells, hemorrhage, and intracytoplasmic basophilic inclusion bodies are common microscopic lesions in all hosts (Table 2, Fig. 4; Reddacliff and Whittington 1996; Cunningham et al. 2007; Allender et al. 2013b; Bayley et al. 2013; Cheng et al. 2014; Waltzek et al. 2014). The liver, spleen, and kidney (including pronephros and mesonephros) are most commonly affected in fatal cases, and can involve both the hematopoietic and non-hematopoietic components of these tissues (Fig. $4 \mathrm{a}-\mathrm{c}$ ). In amphibians, a wide tissue tropism has been observed and additional changes that have been reported include degeneration and ulceration of the epidermis (Cunningham et al. 2007; Geng et al. 2010; Cheng et al. 2014; Meng et al. 2014), necrosis of the GI mucosa (Bollinger et al. 1999), necrosis of lymphoid tissue (Bollinger et al. 1999; Balseiro et al. 2009; Meng et al. 2014), necrosis of neuroepithelial tissue (Docherty et al. 2003), skeletal muscle degeneration (Miller et al. 2008), necrosis of the pancreas (Balseiro et al. 2010; Kik et al. 2011), multicentric hemorrhage, vestibular hemorrhage and necrosis (R. Mazzoni, CRMV-GO, personal communication), and an ocular malformation (Burton et al. 2008). In chelonians, common findings include fibrinoid vasculitis, myositis, and necrotizing pharyngitis, esophagitis, and stomatitis (Fig. 4d; Johnson et al. 2007, 2008; Ruder et al. 2010; Allender et al. 2013b). Similarly, Hyatt et al. (2002) reported necrosis of the pharyngeal submucosa, ulceration of the nasal mucosa, and hepatic degeneration and necrosis in snakes (green pythons, Chondropython viridis). In lizards, ulcerative-necrotizing glossitis, hepatic necrosis, ulcerative dermatitis, and

Table 2 Examples of histopathological changes that can be observed in individuals with ranaviral disease

\begin{tabular}{|c|c|}
\hline Organ & Histopathological change \\
\hline $\begin{array}{l}\text { Kidney (including pronephros of } \\
\text { larvae and mesonephros of adult } \\
\text { amphibians and fish) }\end{array}$ & $\begin{array}{l}\text { Degeneration or necrosis (tubular epithelial cells and } \\
\text { glomeruli), intracytoplasmic inclusions, necrosis of } \\
\text { hematopoietic tissue }\end{array}$ \\
\hline Liver & $\begin{array}{l}\text { Degeneration or necrosis (sinusoids, } \\
\text { melanomacrophage centers, hepatocytes), } \\
\text { intracytoplasmic inclusions, necrosis of hematopoietic } \\
\text { tissue }\end{array}$ \\
\hline Spleen & Necrosis, intracytoplasmic inclusions \\
\hline Pancreas & Necrosis, intracytoplasmic inclusions \\
\hline Muscle & Degeneration of muscle fibers, hemorrhage \\
\hline $\begin{array}{l}\text { Skin (especially lizards, fish, and adult } \\
\text { amphibians) }\end{array}$ & $\begin{array}{l}\text { Erosion, ulceration, hemorrhage, intracytoplasmic } \\
\text { inclusions }\end{array}$ \\
\hline Thymus, lymphoid tissue & Depletion, apoptosis, necrosis \\
\hline Gastrointestinal tissue & $\begin{array}{l}\text { Apoptosis, necrosis of epithelial cells, } \\
\text { intracytoplasmic inclusions }\end{array}$ \\
\hline Vessels & Necrosis (endothelial cells) \\
\hline $\begin{array}{l}\text { Upper respiratory tract (especially } \\
\text { cheolians and snakes) }\end{array}$ & Necrosis of epithelial cells, intracytoplasmic inclusion \\
\hline
\end{tabular}



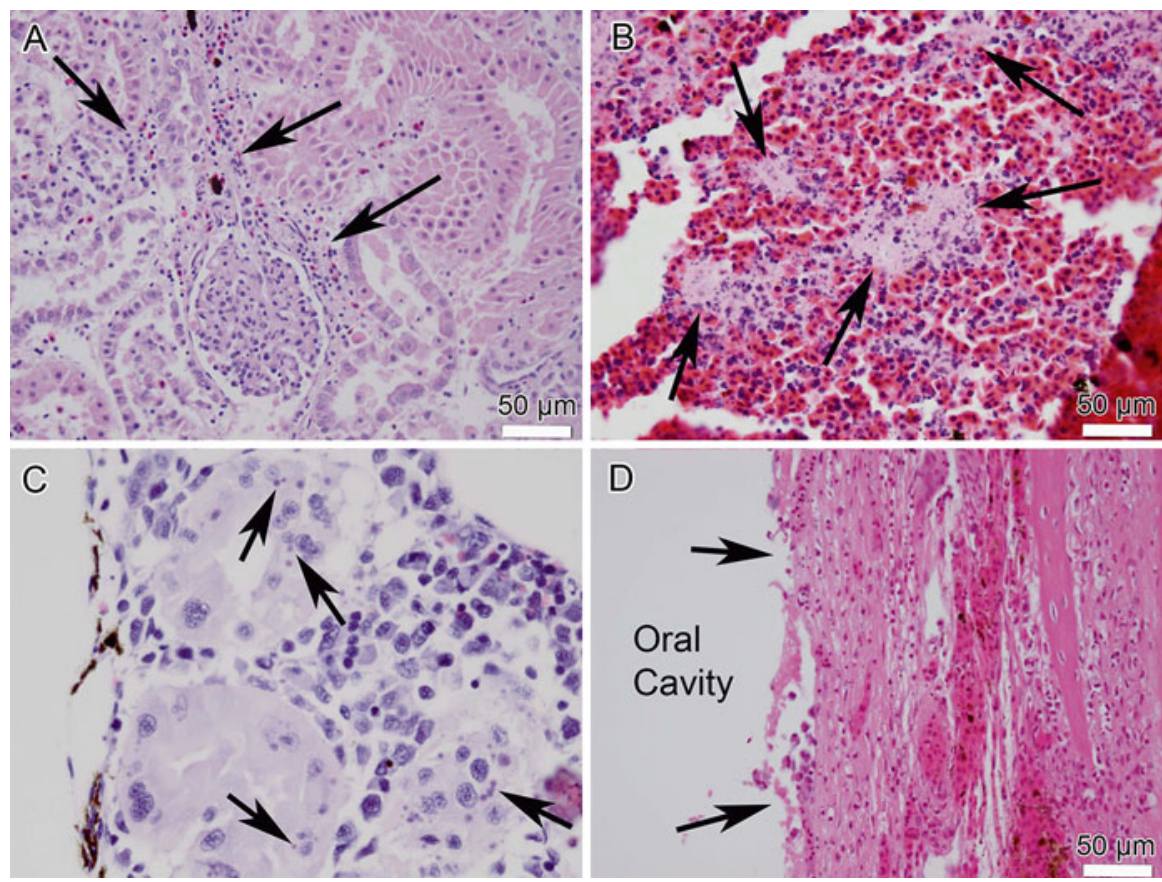

Fig. 4 Histopathological changes seen in individuals with ranaviral disease from experimental challenges with FV3-like ranaviruses. (a) Necrosis (arrows) of the hematopoietic tissue within the kidney of a pallid sturgeon (Scaphirhynchus albus). (b) Necrosis (arrows) of the spleen of a dusky gopher frog (Lithobates sevosus). (c) Intracytoplasmic inclusion bodies (arrows) within the renal tubular epithelial cells of a Southern leopard frog (Lithobates sphenocephalus). (d) Necrosis (arrows) of the mucosa of the oral cavity of a red-eared slider (Trachemys scripta elegans)

secondary infections have been reported (Marschang et al. 2005; Behncke et al. 2013; Stöhr et al. 2013, Fig. 5). In chelonians, lesions of necrotizing stomatitis and pharyngitis overlap significantly with those seen with herpesvirus and adenovirus infections (Johnson et al. 2005; Rivera et al. 2009).

\subsubsection{Subclinical Infection}

Subclinical infections may play an important role in the epidemiology of rana viruses (Brunner et al. 2015). It is instructive to note that the original amphibian ranavirus isolates (Frog virus-1, -2, and -3) were from animals that were, with the exception of one with a renal tumor, ostensibly normal (Granoff et al. 1966). Subclinical infections have been detected in wild amphibians (Gray et al. 2007, 2009; Rothermel et al. 2013), chelonians (Allender et al. 2013b; Goodman et al. 2013), and fish (Goldberg 2002; Whittington et al. 2010). Additionally, subclinical infections have been experimentally produced in amphibians (Brunner et al. 2004; Harp and Petranka 2006; Robert et al. 2007, 2011), chelonians (Johnson et al. 2007; 

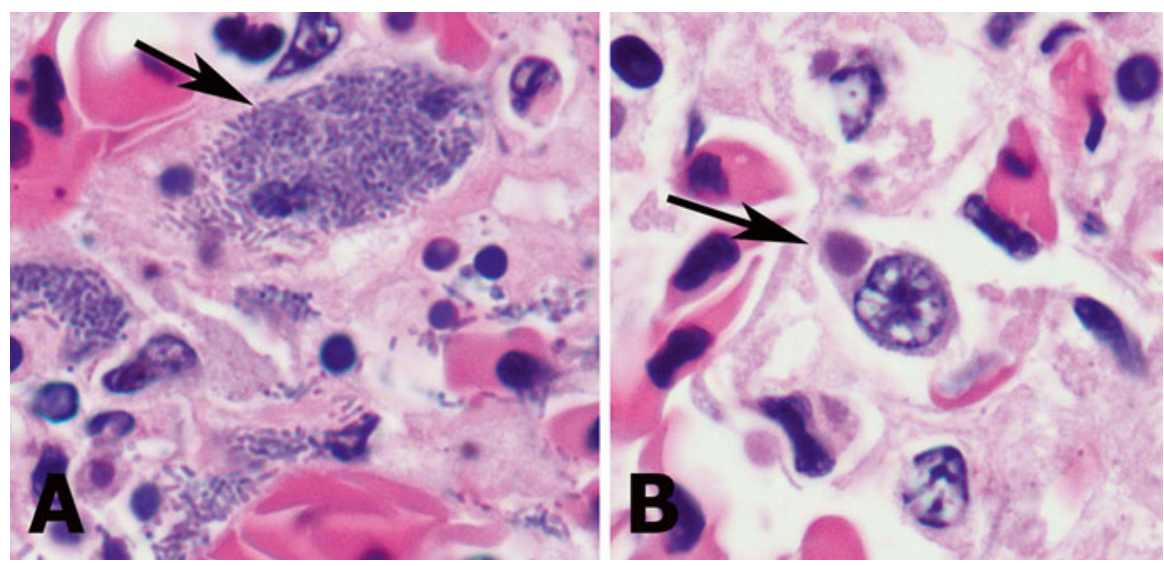

Fig. 5 Histopathology of ranaviral disease with superimposed secondary bacterial infection in an American bullfrog (Lithobates catesbeianus). (a) Bacterial colonies and necrosis in the spleen (arrows) can obscure subtle evidence of ranavirus infection. (b) Careful examination of the histologic sections from this individual revealed rare intracytoplasmic inclusion bodies highly suggestive of ranavirus infection

Brenes et al. 2014a, b), and fish (Bang Jensen et al. 2011; Becker et al. 2013; Brenes et al. 2014a, b). Individuals that are subclinically infected sometimes have nonspecific histologic changes such as vacuolation of renal tubular epithelium and hepatocytes (Miller et al. 2011; Allender et al. 2013b). Ana Balseiro (SERIDA, personal communication) has observed positive immunohistochemical staining in renal glomeruli of adult common midwife toads (Alytes obstetricans) with no clinical signs of disease. In most of the studies above, it is unknown whether the subclinical infections would have developed into clinical disease, because individuals were euthanized or released into the environment. It is likely that subclinical infections represent early stages of ranaviral disease in some cases, while in other cases, infections are resolved or persistent infections are maintained.

\section{Diagnostic Testing}

\subsection{World Organization for Animal Health (OIE) Standards}

The OIE provides recommendations and protocols on diagnostic testing for various animal pathogens (http://www.oie.int). One goal of the OIE is to provide procedures to declare an international shipment of animals or a site, region, or nation as pathogen free for a particular agent. Agents of concern to the OIE are called notifiable and deemed to be a risk to international commerce or human health. Ranaviruses that infect amphibians and EHNV are listed as notifiable, hence sampling and 
diagnostic procedures are provided in the Diagnostic Manual for Aquatic Animal Diseases published by the OIE (OIE 2012c, d). The OIE reference laboratory for ranaviruses can provide reagents and procedures for diagnostic testing as well as perform diagnostic testing (Table 3). Gray et al. (2015) discuss how to perform a risk analysis for introduction of ranavirus into an area following OIE procedures.

Considering the scope of OIE is to detect ranaviruses for the purpose of international trade, the sampling procedures and diagnostic techniques they outline may not be applicable for all investigations. In general, we recommend that the procedures in Gray et al. (2015) be followed for determining required sample size and designing studies for ranaviruses. The diagnostic procedures recommended by OIE also may not be applicable for all regions of the world or may be cost prohibitive. Below, we review the majority of diagnostic techniques used to detect ranavirus infection and determine if individuals are in a diseased state. Table 4 provides guidance as to what techniques can be used given general study directions. In general, we recommend that investigators consult with experts that routinely perform ranavirus diagnostics so that appropriate techniques are chosen to address the particular goals of a study. Importantly, the appropriate sample collecting procedures can depend on the diagnostic technique that is used. The Global Ranavirus Consortium (GRC) maintains a list of laboratories on their website that routinely perform ranavirus diagnostics (http://www.ranavirus.org/).

Table 3 Contact persons for the OIE Reference Laboratory for ranavirus reagents, protocols, and testing

\begin{tabular}{l|l}
\hline Contact person & Contact information \\
\hline Dr. Nick Moody & CSIRO Livestock Industries \\
& Australian Animal Health Laboratory \\
& Private Bag 24 (Ryrie Street) \\
& Geelong \\
& Victoria 3220 \\
& Australia \\
& Tel: +61-3 52 27 00 00 Fax: +61-3 52 275555 \\
& Email: nick.moody@ csiro.au \\
& Web: www.csiro.au \\
\hline Dr. Richard Whittington & University of Sydney \\
& Faculty of Veterinary Science \\
& 425 Werombi Road \\
& Private Bag 3 \\
& Camden NSW 2570 \\
& Australia \\
& Tel: +61-2 93 51 16 19 Fax: +61-2 93 51 1618 \\
& Email: richardw @ camden.usyd.edu.au \\
\hline
\end{tabular}




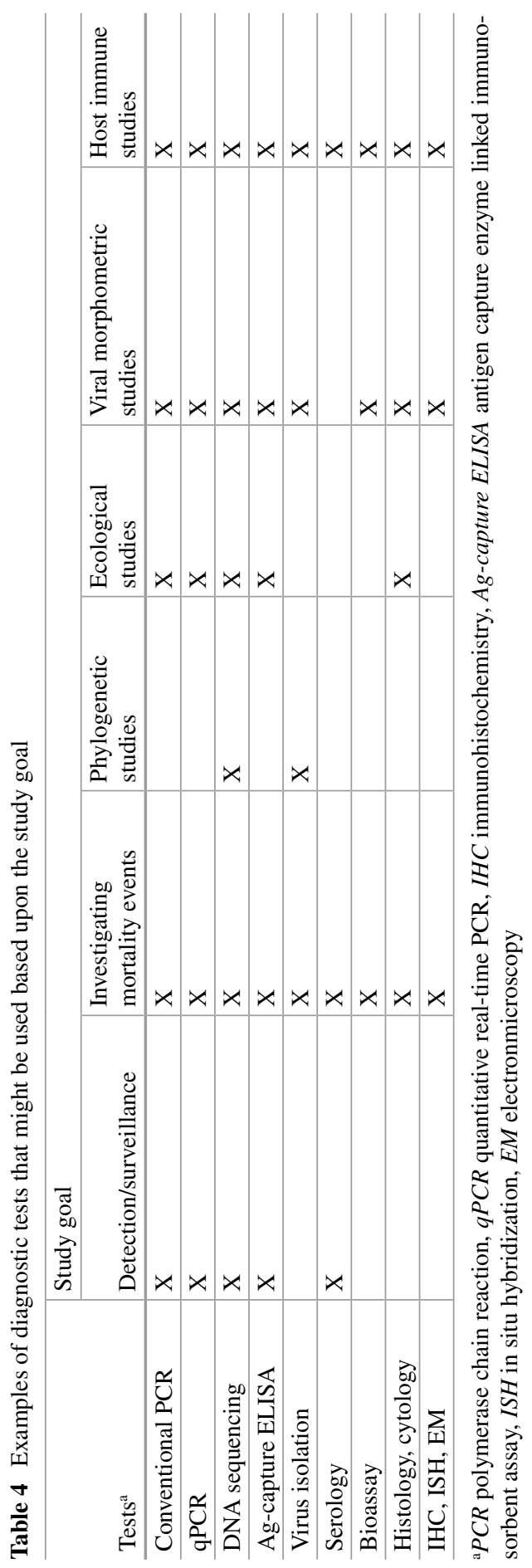




\subsection{Matching Diagnostic Tests with Study Goal}

Investigations into ranaviruses have various purposes, and depending on the goal, some diagnostic techniques may be more appropriate than others. Moreover, the diagnostic needs for field vs. controlled studies can be different. In general, most investigations can be classified as detection of ranavirus for facilitating trade according to OIE guidelines (Gray et al. 2015), detection for mapping distribution and estimating prevalence or incidence (Gray et al. 2015), isolation for phylogenetic classification (Jancovich et al. 2015a), viral morphometrics and host immune response (Jancovich et al. 2015b; Grayfer et al. 2015), ecological factors related to emergence (Brunner et al. 2015), and diagnosis of mortality events (Duffus et al. 2015). Although techniques are constantly being developed and improved, common diagnostic tools used for ranavirus investigations include those that can detect ranavirus and those that can detect the host response to infection. For example, the polymerase chain reaction (PCR) simply detects the presence of nucleic acid for a virus-specific sequence, but does not provide evidence as to whether the virus is active (i.e., able to replicate and cause disease). However, virus isolation demonstrates the presence of infectious virus. Similarly, other tests (e.g., histology, cytology, gene expression, antibody production) detect the cellular response to the infection. Techniques that demonstrate the presence of virus within a lesion such as electron microscopy (EM), immunohistochemistry (IHC), and in situ hybridization (ISH) are particularly useful for demonstrating an association between the presence of the virus and expression of disease. In general, investigations with the primary goal of ranavirus detection (e.g., surveillance studies) will use PCR or an antigen detection technique, phylogenetic studies will use virus isolation and genomic sequencing, ecological studies will use molecular modalities and histology, and viral morphometric studies, host immune studies, and mortality investigations may use all techniques (Table 4). Additionally, confirmation of ranavirus as the etiologic agent of a die-off requires use of multiple techniques, and information on pathological changes within cells is needed. Importantly, diagnosis of ranaviral disease cannot be inferred solely with infection data or the observation of gross signs.

Along with study goals, the type of sample may dictate the type of test that can be performed (Table 5). Nonlethal samples generally include swabs, tail or toe clips, and blood because these are generally easily collected (Greer and Collins 2007; Gray et al. 2012). Swabs should have plastic or wire (not wood) shafts to avoid PCR inhibitors (Pessier and Mendelson 2010). Swabbing should be done by firmly but not forcefully swiping (one to multiple times) the swab along the surface to be tested. Surfaces that are swabbed for ranaviruses typically include the oral cavity, cloaca, or skin lesions (Pessier and Mendelson 2010). Swabbing the vent might provide evidence of intestinal shedding. Tail or toe clips also can be effective at detecting ranavirus infection, and might result in fewer false negative test results compared to swabs (Gray et al. 2012). For salamanders, there generally are natural breakpoints near the tip of the tail where light pressure can be applied to autotomize the tail and collect tissue without cutting (Sutton et al. 2014b). Swabs or tissues can be stored frozen or in ethanol. 
Table 5 Various specimens used for Ranavirus testing, the type of test that can be performed, and the limitations of the test result

\begin{tabular}{l|l|l}
\hline Specimen & Test & Limitations \\
\hline Swab & PCR, virus isolation & $\begin{array}{l}\text { False positives (environmental contamination); } \\
\text { total DNA may be minimal; no histology }\end{array}$ \\
\hline Tail or toe clip & PCR, virus isolation & $\begin{array}{l}\text { False positives (environmental contamination); } \\
\text { no histology }\end{array}$ \\
\hline $\begin{array}{l}\text { Whole body or } \\
\text { internal organs }\end{array}$ & $\begin{array}{l}\text { PCR, virus isolation, } \\
\text { histology, IHC }\end{array}$ & Dead animals \\
\hline Fixed tissue & PCR, histology, IHC & $\begin{array}{l}\text { No virus isolation, electron microscopy is } \\
\text { possible }\end{array}$ \\
\hline Blood & PCR, virus isolation & $\begin{array}{l}\text { Best obtained from live animals; can be difficult } \\
\text { to obtain; often cannot obtain large enough } \\
\text { quantity from small individuals }\end{array}$ \\
\cline { 2 - 3 } & \begin{tabular}{l} 
ELISA if serum separated \\
\cline { 2 - 3 } $\begin{array}{l}\text { Differential cell count if } \\
\text { blood smear is prepared }\end{array}$
\end{tabular} & \\
\hline
\end{tabular}

Disposable gloves should be worn and changed between animals to minimize crosscontamination of samples, and to prevent unintentionally transmitting the virus among animals. Additionally, individual animals should not be co-housed, and processing in the field should occur on a sterile surface (Fig. 6). For tail or toe clips, sterile instruments must be used to avoid sample contamination. We recommend using a different sterile (e.g., autoclaved) set of instruments for each animal. Although ranavirus can be quickly inactivated by various disinfectants (Byran et al. 2009), cross-contamination (and thus false positive results with molecular testing) can occur if ranavirus DNA is not degraded. While degradation studies have not been performed for ranaviruses, autoclaving, flaming, and long duration soaking $(>12 \mathrm{~h})$ in full strength bleach $(6 \% \mathrm{NaOCl})$ have been used to degrade DNA for other pathogens (Cashin et al. 2008). Some researchers are investigating the use of liver aspirates (Forzan and Wood 2013); however, the feasibility in field collection and the need for expertise in collection may limit their use. Blood can be collected from multiple locations, including the caudal vein (fish, caudates, snakes), subcarapacial sinus or occipital venus sinus (turtles, Martínez-Silvestre et al. 2002; Allender et al. 2011), abdominal and facial veins (anurans, Forzan and Wood 2013), and heart (anurans, snakes).

Detailed reviews of sample collection protocols for amphibian necropsy and mortality events are available (Green et al. 2009; Pessier and Mendelson 2010). In brief, submission of whole moribund animals sent overnight to a diagnostic laboratory are preferred. However, if this is not possible, tissue samples may be collected and submitted. It is important to realize that if a sample is submitted for only one test, the result will only be positive or negative for that one pathogen by that one test. If positive, the pathogen may or may not have played a role in morbidity and mortality. If negative, the cause of the morbidity and mortality will remain undetermined. Thus, ideally multiple samples should be submitted and multiple diagnostic tests performed. At minimum, tissue collection should include the major organs (liver, kidney, spleen, lungs/gills, heart, skin, digestive tract) and any lesions 

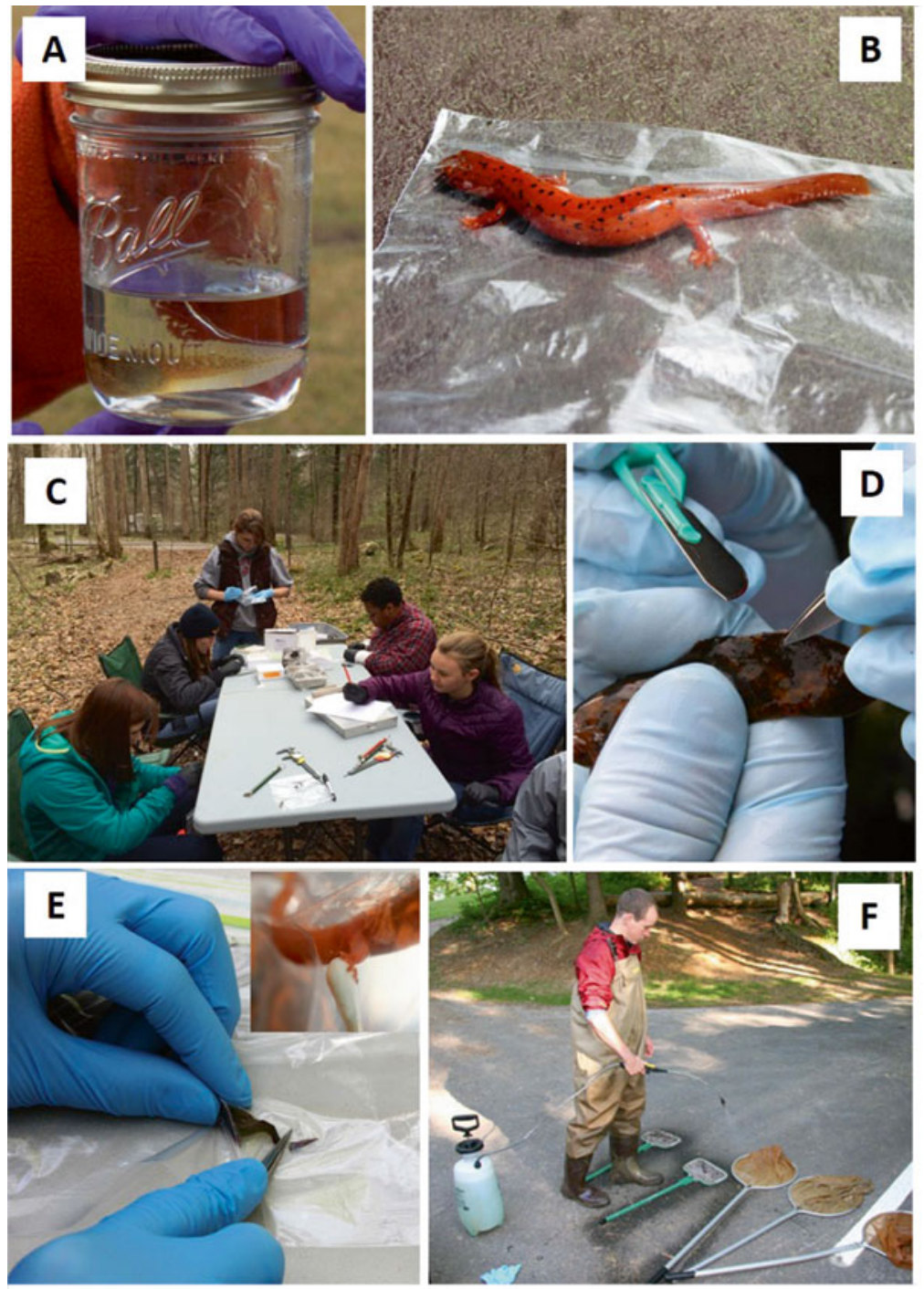

Fig. 6 Field sampling station demonstrating sterile collection techniques. Animals should be placed in separate containers, such as glass jars containing sterile water for aquatic stages (a) or plastic sealable bags for terrestrial stages (b). A portable table can serve as a processing station that can be easily disinfected after each field site (c). A sterile set of instruments should be used for each animal. For some species (e.g., Hellbenders, Cryptobranchus alleganiensis) a small slice can be collected from the dorsal tail using a sterile disposable scalpel and forceps (d). For many salamander species, there are natural break points in the tail that can easily yield a tail sample by simply applying gentle pressure near a break point, and can be done without removing the animal from the bag (e). When testing for concurrent Batrachochytrium dendrobatidis infection, swabbing can be accomplished within the containers as well (e inset). All equipment, waders, and boots should be disinfected (e.g., with $1 \%$ Nolvasan $^{\circledR}$ ) before leaving a field site (f) 
noted. A set of these tissues should be submitted fresh or frozen for pathogen testing, and a set should be submitted fixed (e.g., $10 \%$ buffered formalin) for histological evaluation. Samples should be triple packaged in leak-proof containers and shipped following the guidelines of the carrier (e.g., http://www.fedex.com/ downloads/hk_english/packagingtips/pointers.pdf). Autolyzed samples are of little diagnostic value but, if they are all that remain, it may be possible to glean some information. It is best to contact the diagnostic laboratory before submission of any samples, but especially before submitting autolyzed samples. As mentioned, a list of diagnostic laboratories can be found on the GRC website. Importantly, researchers should disinfect footwear and sampling gear that comes in contact with potentially infected animals or water that contains ranavirus. Nolvasan ${ }^{\circledR}(1 \%$, Fort Dodge Animal Health, Fort Dodge, Iowa, USA) and bleach (4\%) are effective at inactivating ranavirus, as well as other pathogens such as the amphibian chytrid fungus (Bryan et al. 2009, Gold et al. 2014).

\subsection{Diagnostic Tests}

Confirmation of the presence of ranavirus in host tissues can be achieved using various methods, including virus isolation, EM, antigen-capture enzyme-linked immunosorbent assay (Ag-capture ELISA), IHC, and PCR. Of these tests, all may be performed on specimens collected from dead organisms with minimal postmortem change, and most can be performed on specimens collected from live organisms (Table 5). Some tests (e.g., PCR) may yield results even with advanced autolysis, but this is not ideal. For all tests, it is necessary to prepare tissues in order to release ranavirus from the host cells. Several validated methods that incorporate automated, semi-automated, and manual homogenization of tissues have been described and compare the extraction efficiencies of ranavirus from tissues (Whittington and Steiner 1993; Rimmer et al. 2012). Extraction efficiency is especially important if viral loads are low in tissues, such as in subclinical infections. Additionally, all tests should include positive and negative controls. For example, positive PCR controls typically include extracted DNA from a virus isolate and known infected animal; whereas, negative controls typically include extracted DNA from a known negative animal and DNA grade water. In this scenario, the controls verify that the test was effective and had low contamination likelihood.

\subsubsection{Polymerase Chain Reaction}

Both conventional and quantitative real-time PCR (qPCR) are used to detect ranavirus DNA. The PCR assays can be performed on a variety of specimens, including fresh tissue, formalin-fixed paraffin-embedded tissues, and swabs. In the most 
commonly used assays, the major capsid protein (MCP) gene is targeted (Mao et al. 1997; Hyatt et al. 2000; Kattenbelt et al. 2000; Marsh et al. 2002; Pallister et al. 2007). The MCP gene is highly conserved, which makes it a desirable region to target for identifying the presence of ranavirus DNA; however, it has limitations if the goal is to explore subtle genomic or phylogenic differences among isolates within a particular Ranavirus species (Jancovich et al. 2015a). Other targets for PCR have included the neurofilament triplet H1 protein (Holopainen et al. 2009), DNA polymerase (Holopainen et al. 2009), and an intergenic variable region (Jancovich et al. 2005).

The sensitivity of PCR may vary depending on the type of specimen tested. In general, it is considered that tissue samples from internal organs represent infection status better than nonlethal sampling techniques such as tail clips, toe clips, and swabs (Greer and Collins 2007; Gray et al. 2012). Given that ranavirus tropism differs among tissue types and host postexposure duration (Robert et al. 2011; Ma et al. 2014), it is expected that PCR test results will depend on the tissue used. In frogs infected with FV3, ranavirus is first detected in the kidney and intestines (Robert et al. 2011), then the liver, spleen, and other major organs. Thus, testing different tissues can provide evidence of infection severity. Commonly, researchers test for infection using a homogenate of different tissues (e.g., Hoverman et al. 2011) to increase detection probability.

Testing for ranavirus in nonlethal samples can lead to false-negative and -positive results when compared to whole animal or liver samples (Greer and Collins 2007; Gray et al. 2012). False negative results may be caused by insufficient virus in swabs or tail- and toe clips; whereas, false positive results could be caused by virus on the outside of the animal being detected (Gray et al. 2012). Regardless, nonlethal sampling techniques can be useful for ranavirus surveillance if animal collections are not allowed or population abundance is low.

It is important to note that PCR assays are not perfect, implying that some rate of false positive and false negative results are expected even when a laboratory procedure with excellent analytical characteristics is performed without error. Accurate interpretation of PCR results requires estimation of the diagnostic sensitivity and diagnostic specificity of the assay so that the positive and negative predictive value of the result can be calculated (Greiner and Gardner 2000). These characteristics are measured when a test protocol is validated for a specific sample type and host species. Occasionally, when the quantity of virus present is low, different results from the same sample can occur. At minimum, we recommend that all samples tested by qPCR are run in duplicate (although triplicate is preferred) on the same qPCR machine, and only samples with consecutive positive results are declared positive. If one sample appears positive and the other negative, a third sample can be run and the declaration of infection made based on the majority of the results. Ongoing research (E. Grant, U.S. Geological Survey, and DLM) is estimating detection probabilities of qPCR using the protocol of Picco et al. (2007) and double sampling procedures. 


\section{Conventional PCR}

Conventional PCR has been used to detect ranaviral infection in fresh or fixed tissue specimens from surveillance studies and mortality events, as well as the identification of cultured virus (Miller et al. 2007; Gray et al. 2009; Meng et al. 2014). Phylogenetic mapping of banked DNA sequences (GenBank) representing isolates from throughout the world reveals significant sequence identity, which has been exploited in designing primers for detection of ranaviruses by PCR. In addition, sequence polymorphisms within the MCP can be used to distinguish some isolates to genus level (e.g., FV3, EHNV) by restriction digestion of amplicons from conventional PCR (Marsh et al. 2002; Holopainen et al. 2009). Conventional PCRs for detection of ranaviruses and restriction endonuclease analysis (REA) for subtyping are described in the OIE Diagnostic Manual for Aquatic Animal Diseases (OIE 2012c, d).

DNA sequencing of conventional PCR products to confirm positive results may not always be necessary, especially in endemic regions. However, amplification of non-ranaviral DNA can occur with the commonly used MCP primer sets (A. Pessier, unpublished data). Thus, sequencing of at least a subset of positive results is suggested when new hosts are affected or ranavirus is detected in regions previously thought to be free of these viruses. Sequencing of PCR products can also be informative for preliminary genus-level virus identification (e.g., FV3-like or Ambystoma tigrinum virus [ATV]-like).

\section{Quantitative Real-Time PCR}

The advent of qPCR has provided significant advances in the study of various pathogens and their virulence. Studies have found that qPCR is more sensitive than conventional PCR as it can detect lower viral loads and be more sensitive than virus isolation (e.g., Pallister et al. 2007; Jaramillo et al. 2012). Pallister et al. (2007) found that qPCR could differentiate between a number of ranaviruses that infect fish, amphibians, and reptiles, and was especially effective at distinguishing European from Australian ranaviruses. A useful protocol for amphibians was reported by Picco et al. (2007), which amplifies a 70-bp region of the Ranavirus MCP gene; Allender et al. (2013a) developed a similar assay for chelonians. Viral load can be estimated when the genomic DNA in samples is quantified, and equal amounts of DNA used from each specimen tested. Viral load is predicted by entering the cycle threshold $(\mathrm{Ct})$ value for a sample into a regression equation (called the standard curve) that relates $\mathrm{Ct}$ values and known virus quantities for the PCR, system that is used for testing (Yuan et al. 2006). Importantly, Ct values on different PCR systems are not equivalent; thus, conversion of $\mathrm{Ct}$ values to a standard unit of virus quantity using a standard curve is necessary for interpretation among studies. Typically, the standard unit of measurement is a $\log _{10}$-transformed value of virus concentration per unit of genomic DNA or tissue. For example, Brenes et al. (2014a) reported virus levels as plaque-forming units (PFU) per $0.25 \mu \mathrm{g}$ of genomic 
DNA. Results of PCR systems can vary among runs; thus, it is ideal to estimate a standard curve for each run (i.e., plate). Guidelines are available for reporting results for quantitative PCR assays (Bustin et al. 2010). Slope and intercept parameters for the standard curve can be averaged among multiple independent runs for a more robust estimate of viral load, similar to model averaging. Standard curves should be published with qPCR results.

Given that pathogen load often is positively related to morbidity in animals, qPCR might provide insight into the disease state (clinical vs. subclinical), but this remains to be shown for ranaviruses. Caution must be exercised when interpreting high $\mathrm{Ct}$ values (e.g., $\mathrm{Ct}$ values $>35$ ), because they can represent amplification or fluorescence artifacts, or cross-contamination (Caraguel et al. 2011). Conventional PCR, followed by DNA sequencing or virus isolation, can be used to verify viral DNA presence within samples having high $\mathrm{Ct}$ values. Additionally, a standard curve for the PCR system can be used to identify a Ct threshold where the sample is declared PCR-positive. For example, Brenes et al. (2014a, b) conservatively declared a positive result if the $\mathrm{Ct}$ value was less than the lower bound of a $95 \%$ confidence interval at a predicted virus quantity of zero. In general, data on the diagnostic sensitivity and specificity of published qPCR tests for ranavirus are lacking. However, the test described by Jaramillo et al. (2012) has been validated for EHNV and will be described in the forthcoming new edition of the OIE Manual. Similarly, Allender et al. (2013a) validated the qPCR for detection of FV3-like virus in eastern box turtles (Terrapene carolina carolina).

\section{Differentiation of Ranavirus Species and Strains}

In most routine diagnostic and research situations, existing PCR assays based on the MCP gene work well for determining the presence or absence of a ranavirus or to categorize a virus into a major species group (e.g., an "FV3-like" virus, Jancovich et al. 2015a). However, in other instances such as epidemiologic investigations that need to determine the distribution of different ranavirus strains or translocation programs for wildlife species where it may be important to determine if the same ranavirus is present in both source and destination populations, these assays are not as useful because the MCP gene is so highly conserved (Jancovich et al. 2015a). As an example, it is now well documented that different strains of FV3 as determined by genomic REA frequently have identical DNA sequences within regions of the MCP gene commonly used in diagnostic conventional PCR (Schock et al. 2008; Duffus and Andrews 2013).

The laboratory techniques used to differentiate specific ranavirus strains such as virus isolation and purification followed by genomic REA are not available in all laboratories and are not practical for some studies; therefore, there is a need to find and validate methods for rapid strain identification. One possible approach is genotyping using conventional PCR and DNA sequencing for genes such as the intergenic variable region (Jancovich et al. 2005; Weir et al. 2012) or neurofilament triplet H1-like protein (Holopainen et al. 2009; Cheng et al. 2014) that contain variable 
repeating regions. By using consistent approaches for selection of sequencing targets, researchers ensure that advances in the understanding of ranavirus phylogeny and epidemiology can be more rapidly obtained.

\subsubsection{Antigen-Capture ELISA}

The analytical sensitivity of Ag-capture ELISA applied to fish tissue homogenates for detection of EHNV was $10^{3}-10^{4} \mathrm{TCID}_{50} / \mathrm{ml}$. Antigen-capture ELISA is useful for diagnosis and surveillance because it can be applied quickly (compared to virus isolation) and inexpensively (compared to molecular assays) to test large numbers of samples. Relative to virus isolation, the diagnostic specificity and sensitivity of Ag-capture ELISA was $100 \%$ and $60 \%$, respectively (Whittington and Steiner 1993).

\subsubsection{Virus Isolation}

Virus isolation using well-characterized cell lines that are commercially available from cell repositories is another approach for determining the presence of ranavirus. Additional advantages of cell culture techniques include demonstration of viable virus, and amplification of it for further characterization. Culture specimens also may yield better PCR results and ultimately better products for sequencing than tissue specimens. EHNV replicates in many fish cell lines including fathead minnow (FHM), rainbow trout gonad (RTG), bluegill fry (BF-2), and Chinook salmon embryo (CHSE-214) at a range of temperatures from 15 to $22{ }^{\circ} \mathrm{C}$ (Langdon et al. 1986; Crane et al. 2005; Ariel et al. 2009; OIE 2012c). European catfish virus can be isolated using Epithelioma papulosum cyprinid (EPC) cells, FHM, and channel catfish ovary $(\mathrm{CCO})$ cells at $15-25^{\circ} \mathrm{C}$, but BF-2 cells were tenfold more sensitive than EPC and CCO cells (Ahne et al. 1989; Pozet et al. 1992). Santee-Cooper ranavirus was originally isolated from largemouth bass in FHM cells (Plumb et al. 1996); and subsequently in BF-2, EPC, and CCO cells at $25-32{ }^{\circ} \mathrm{C}$ (McClenahan et al. 2005). Grouper iridovirus can be propagated on a range of cells including FHM and BF-2, but more rapid cytopathic effect (CPE) and higher titres were observed in Grouper (GP) embryo cells (Qin et al. 2003).

Ranaviruses commonly found in amphibians can be isolated on some fish cells as well as amphibian cells. Incubation temperature can vary and is a critical consideration for optimum results. For example, ATV reproduces on FHM, RTG, and bullfrog tongue cells at $25^{\circ} \mathrm{C}$ (Docherty et al. 2003), FV3 on FHM cells or frog embryo fibroblasts at $27{ }^{\circ} \mathrm{C}$ (Cunningham et al. 1996, 2007) and EPC at $24{ }^{\circ} \mathrm{C}$ (Ariel et al. 2009), and CMTV can be propagated on EPC at $15^{\circ} \mathrm{C}$ (Balseiro et al. 2009). Ma et al. (2014) and Geng et al. (2010) found that Chinese Giant Salamander Virus (CGSV; also designated as Chinese Giant Salamander Iridovirus, GSIV) could be propagated on EPC at $25{ }^{\circ} \mathrm{C}$ and $20^{\circ} \mathrm{C}$, respectively. 
All ranaviruses produce a similar CPE with focal lysis of cells, which typically is followed within a few days by destruction of the entire monolayer (Fig. 7). Ranavirus CPE presents as a net-like appearance on monolayers of FHM cells (G. Chinchar, personal communication); however, the appearance of CPE is not sufficient to indicate that a ranavirus is the cause. When CPE is observed in cell monolayers after passage, several techniques can be used to confirm the presence of a ranavirus. Suitable techniques include indirect fluorescent antibody stain, Ag-capture ELISA, and PCR (OIE 2012c). Alternatively, viral nucleic acid sequencing or restriction enzyme digestion can demonstrate the presence of a ranavirus and allow for differentiation between species and strains (Hyatt et al. 2000; Marsh et al. 2002). The virus isolation technique can be adapted to determine the quantity of infectious virus (i.e., the $50 \%$ tissue culture infective dose, $\mathrm{TCID}_{50}$; Rojas et al. 2005).

Virus isolation requires that viability of the virus is maintained from the field to the laboratory. Thus, this technique requires an appropriate cold chain throughout transport and transfer, or false-negative results could occur (OIE 2012d). Autolyzed tissues also should be avoided. Virus isolation using cell culture has a very high analytical sensitivity, but is not as sensitive as real-time PCR. For example, detection of EHNV using BF-2 cells was 100-fold less sensitive than qPCR (Jaramillo et al. 2012). When used for the purpose of surveillance and to detect subclinical infection, the sensitivity of virus isolation requires preparation techniques that ensure maximum release of cell-associated virus from the tissues (Whittington and Steiner 1993). Recently, modification of these methods using high-throughput laboratory technologies such as bead-beating were shown to be compatible with virus

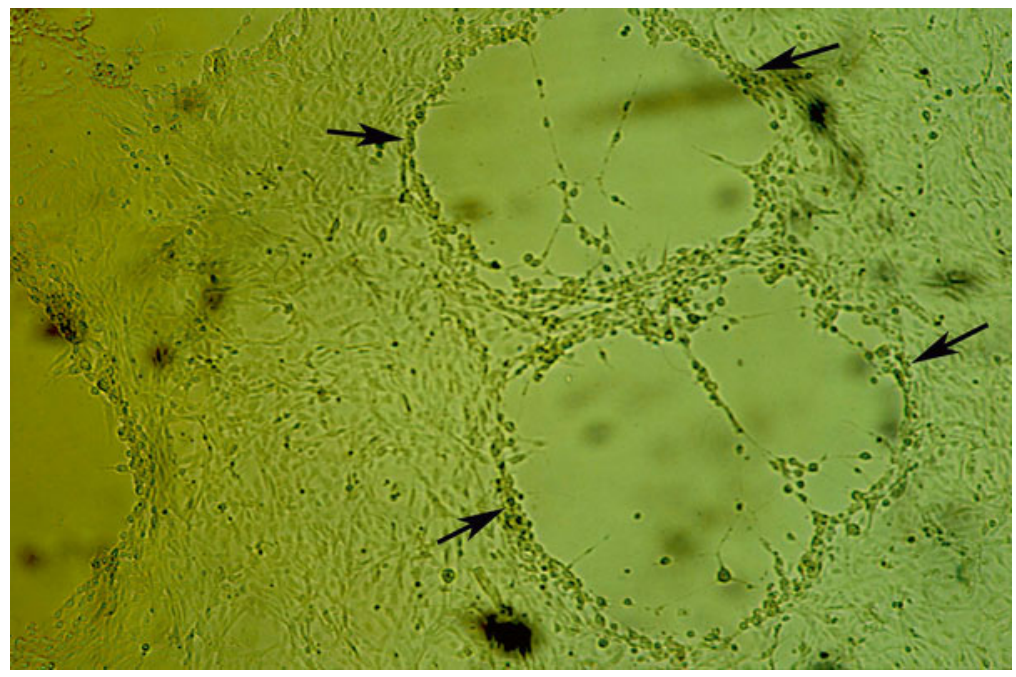

Fig. 7 A typical cytopathic effect (CPE) of EHNV in bluefill fry (BF-2) cells showing multiple foci of lysis of the cell monolayer. Note the rounding of cells on the margins of the lytic areas (arrows). After a few days, destruction of the entire monolayer can be expected 
isolation and increased the sensitivity of qPCR for detection of EHNV (Rimmer et al. 2012). Ranaviruses are abundant in the liver, kidney, and spleen of clinically affected fish, amphibians, and reptiles. For Santee-Cooper ranavirus, it was suggested that gills, swim bladder, and posterior kidney should be used as a minimum sample (Beck et al. 2006), while a pool of kidney, liver, and spleen is preferred for EHNV.

Virus isolation provides an important tool for basic studies of the replication and morphogenesis of ranaviruses. For example, after initial descriptions of GCSV based on diagnostic tests including isolation on EPC cells (Geng et al. 2010), additional important information about the virus was acquired using EM and proteomic and RNA knockdown studies in EPC cells (Li et al. 2014b; Ma et al. 2014). These types of studies can provide valuable information on virus replication, which may in turn prove useful for developing methods of treatment and control of ranavirus infection.

\subsubsection{Detecting Antibodies: Serology}

An ELISA for detection of antibodies was developed using a combination of antiranavirus antibodies and species-specific anti-immunoglobulin reagents, and has been used to detect a specific adaptive immune responses to ranavirus infection in the serum of redfin perch (Perca fluviatilis), rainbow trout (Oncorhynchus mykiss), and the cane toad (Bufo marinus; Whittington et al. 1994, 1997; Whittington and Reddacliff 1995; Whittington and Speare, 1996). Seroconversion occurred when redfin perch and rainbow trout were injected with inactivated EHNV (Whittington et al. 1994; Whittington and Reddacliff 1995). Serological approaches that target a long-term adaptive immune response to ranavirus infection potentially offer a sensitive method for differentiating host populations with endemic ranavirus infections from areas that are ranavirus free. For example, Whittington et al. (1999) reported a small proportion of seropositive adult rainbow trout in EHNV-infected farmed fish populations. Similarly, anti-ranavirus antibodies have been detected in populations of free-living anurans (Whittington et al. 1997; Zupanovic et al. 1998); and more recently, humoral immune responses have been measured in comprehensive investigations of the pathogenesis of ranavirus infection in Xenopus laevis (Gantress et al. 2003).

Given the success in fish, ELISA testing for an antibody response is being applied to reptiles. Ariel (1997) utilized methods developed by Hengstberger et al. (1993) to detect anti-Bohle iridovirus (BIV) antibodies in wild reptiles in Australia. More recently, Johnson et al. (2007, 2010) and Allender (2012a) used ELISA for surveillance and laboratory investigations to test for the presence of anti-ranavirus antibodies in plasma of various chelonians in the USA.

Serological testing is an easy and cost-effective technique, although it also presents limits. The application of serological tests is limited by the cross-reactivity of antibodies to all ranaviruses and the absence of a secondary test method to evaluate sensitivity and specificity. Virus neutralization tests cannot be used 
because antibodies with neutralizing activity to EHNV were not evoked following immunization of rabbits (Hedrick et al. 1992) or from mouse monoclonal antibodies (Monini and Ruggeri 2002). Current knowledge of the amphibian, reptile, and piscine immune systems indicates limitations to serological techniques that are imposed by a lack of affinity maturation, poor immune memory, and temperature dependence of the response (McLoughlin and Graham 2007). For this reason, the OIE does not currently support serology as a useful strategy.

\subsubsection{Testing in Animals: Bioassay}

A bioassay or experimental transmission trial is an important part of the diagnostic process that is used in cases where a novel ranavirus is detected or disease is detected in a new host or novel ecological setting. An example of this can be found in Waltzek et al. (2014), which describes a mortality event in Pallid sturgeon caused by an FV3like ranavirus. In this case, experimental transmission of the virus isolated from the die-off event was used to infect pallid sturgeon in the laboratory, resulting in a mortality event mimicking the one from which the virus was originally isolated. Subsequent sequencing of the virus revealed it to be most closely related to FV3 (i.e., FV3-like ranavirus).

\subsubsection{Examining the Tissues}

\section{Histopathology and Cytology}

Histopathology is an essential tool for investigating cases of disease with unknown etiology. Characteristic lesions can provide preliminary evidence of certain pathogens and guidance in selecting subsequent diagnostic tests. Histopathology is also important for determining the relevance of ranavirus infection detected during a surveillance study or disease event. Once death of the organism occurs, tissues breakdown (autolyze) quickly, especially in warm conditions, which can obscure microscopic detail. Thus, histology is performed best when using morbid specimens that were collected alive, humanely euthanized (AVMA 2013), and preserved in a fixative immediately after death. A 9:1 ratio of neutral buffered formalin (10\%) to tissue is generally used for fixation (Pessier and Mendelson 2010). Ethanol or other fixatives (e.g., Davidson's or Bouin's) may be preferred for fish tissues. Small animals (e.g., $10 \mathrm{~cm}$ or less) may be placed whole in a fixative if shipping to a diagnostic laboratory. A small ( $5 \mathrm{~mm}$ ) incision into the coelomic cavity will aid in preserving internal tissues. In small fish, this is accomplished by removing the tail and operculum. Larger animals may be opened (necropsied) and representative samples collected from all tissues (see Sect. 2.2) so lesions can be observed grossly and differential diagnoses considered. At the time of necropsy, it is important to collect a second set of samples to be stored fresh (for immediate testing) or frozen 
(for future testing) if histopathology results indicate that lesions consistent with ranavirus infection are present and confirmatory testing is necessary, or to rule out the presence of concurrent pathogens. To prevent cross-contamination, a different set of sterile instruments should be used for each individual.

Often cases of ranaviral disease are not straightforward and require the use of additional diagnostic methods such as IHC, EM, or molecular methods for confirmation. The observation of characteristic intracytoplasmic inclusion bodies is an inconsistent finding, especially in chelonians (DeVoe et al. 2004; Johnson et al. 2007, 2008). In other cases, subtle lesions of ranaviral infection can be obscured by secondary bacterial or fungal infection (Fig. 5).

Although not a definitive test of disease, cytology can be used to document changes in the innate immune system through blood cell counts, and for detection of viral inclusions. Blood may be collected as described above (see Sect. 2.2), and air-dried blood smears stained and subjected to cytological examination with oilimmersion light microscopy. Inclusion bodies may be observed within the cytoplasm of leukocytes (Allender et al. 2006). Although not definitive, inclusion bodies are suggestive of ranavirus infection, when corresponding clinical, gross, and histopathological changes are present. It should be noted that viral inclusions in erythrocytes may represent erythrocytic iridoviruses, which may be a different genus within the family Iridoviridae, especially when seen in reptiles (Wellehan et al. 2008; Grosset et al. 2014).

\section{Tests for Visualizing the Virus}

There are several persistent questions regarding the pathogenicity of ranaviruses: Is ranavirus causing the lesion, where is the virus in subclinical infections, and what cells are infected by the virus and how does this vary by host species and developmental stage? A key factor in pathogenesis is identifying the cell types targeted by the virus. This can be done with histology; however, cellular changes are not always visible, such as with subclinical infections. Additionally, attributing cellular changes due to ranavirus can be challenging with histology, especially in cases of concurrent infection with other pathogens. Visualizing the virus within cells can be useful for attributing cellular changes to ranavirus (Miller and Gray 2010), and can be accomplished using IHC, in situ hybridization (ISH), and EM.

\section{Immunohistochemistry}

For IHC, enzyme-conjugated, virus-specific antisera are used to demonstrate the intracellular location of viral antigens via an enzyme (e.g., horseradish peroxidase or alkaline phosphatase) catalyzed reaction (Fig. 8). Additional approaches have been developed to detect EHNV and European catfish virus (ECV) antigen using polyclonal antisera in Ag-capture ELISA and immunoelectronmicroscopy (Steiner et al. 1991; Hengstberger et al. 1993; Hyatt et al. 1991; Whittington and Steiner 
1993; Ahne et al. 1998). Secondary antibodies suitable for immunofluorescence or enzymatic detection enable the detection of ranavirus antigens in tissue sections and cell cultures (Reddacliff and Whittington 1996). Some antisera are directed against the MCP and are cross-reactive; thus, all ranaviruses can be detected, but it is not possible to distinguish between ranaviruses (Hedrick et al. 1992; Ahne et al. 1998). Other antisera have been developed against purified virions (Balseiro et al. 2009), but again, it might not be possible to distinguish between ranaviruses. Effective use of immunohistochemical staining has been reported for amphibians (see, Hyatt et al. 2002; Cunningham et al. 2008; Balseiro et al. 2009, 2010; Bayley et al. 2013). Balseiro et al. $(2009,2010)$ used IHC to detect the presence of ranavirus in various cells and found that glomeruli appear to have the most positive staining in larval toads but ganglia (particularly in the skeletal muscle) displayed the most positive staining in juvenile newts.

Despite these published reports, IHC is not widely used. Perceived difficulty in obtaining antibodies is often mentioned as the reason for not incorporating it as part of the basic laboratory testing. Primarily, IHC has been used in research studies and often the investigators develop their own antibodies or obtain them from other researchers (e.g., Hyatt et al. 2002; Cunningham et al. 2008; Balseiro et al. 2009, 2010; Bayley et al. 2013; Whitley et al. 2010; Chinchar et al., 1984). This technique may be especially useful to identify inclusion bodies within areas of necrosis, as this can be challenging when abundant cellular debris is present (Fig. 8). IHC may also be positive prior to development of necrosis and inclusions; thus, it may be useful in detecting the presence of virus in animals with subclinical infection. The antibodies recommended by the OIE reference laboratory were developed against a verified strain of highly purified ranavirus, have been pretested, and are of known titer and shelf life (Whittington and Deece 2004). It remains unknown if this is the case for other antibodies developed for IHC. Initial work by A. Balseiro and D. Miller (unpublished data) suggests that there may be differences in IHC results among ranavirus isolates and among hosts.

Another use for IHC is in cases where only fixed tissues are available, such as in diagnostic investigation of mass die-off events where shipping fresh or frozen tissues was not possible. Although PCR can be run on preserved samples and provide information on the presence or absence of ranavirus, the technique cannot verify the virus' involvement in a particular lesion (and thus possibly the cause of death). IHC provides supportive evidence of lesion etiology by microscopically visualizing the association of a pathogen with a lesion.

\section{In Situ Hybridization}

Another approach to visualizing the virus is by ISH, which uses molecular probes to localize specific nucleic acid sequences within fixed tissue sections. For example, specific staining was observed in the kidney and spleen of Malabar grouper, (Epinephelus malabaricus) infected with Singapore grouper iridovirus (SGIV), an iridovirus which affects marine fish and has approximately $83 \% \mathrm{MCP}$ gene 


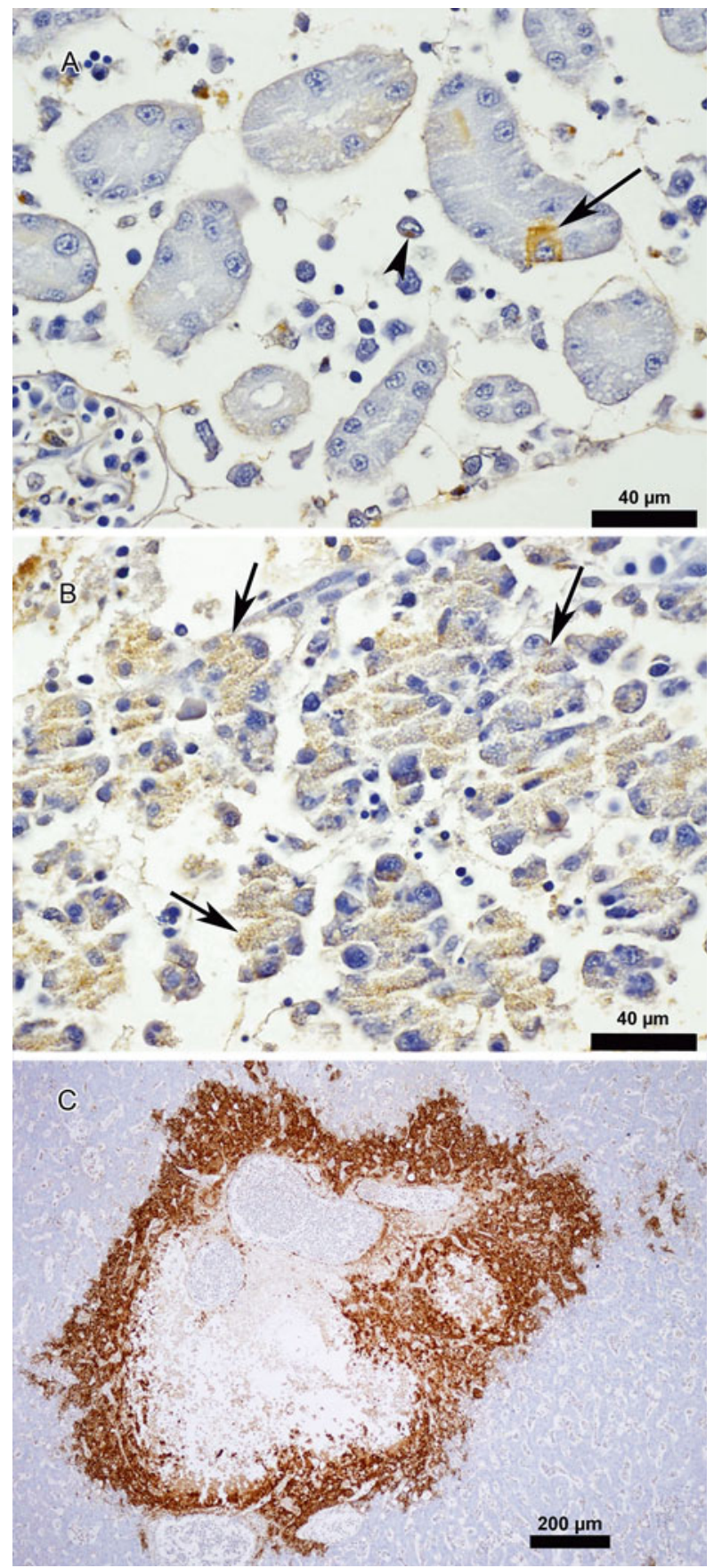

Fig. 8 (a) Immunohistochemical staining for ranavirus in renal tubular epithelial cells (arrow) of a Southern leopard frog (Lithobates sphenocephala). An intracytoplasmic inclusion body within a hematopoietic cell (arrowhead) also stains positive. (b) Positive staining (arrows) is present throughout the spleen of the Southern leopard frog. (c) Positive staining in the liver of a redfin perch (Perca fluviatilis) 
sequence homology with FV3 (Huang et al. 2004). Although reports of the use of ISH for ranaviruses are few, future studies might consider using this technique as the need to document pathogenesis of ranaviral disease increases.

\section{Electron Microscopy}

Electron microscopy (EM) is used for visual confirmation of the identity of cultured virus and for visualizing the virus within tissue sections. Verification of the cultured product involves negative staining and assessment via scanning EM (SEM); whereas, preserved tissues are used to visualize the virus within the tissues by transmission EM (TEM). For example, Burton et al. (2008) used TEM to examine the ultrastructure of tissues from a malformed eye of a preserved specimen. Electron microscopy revealed that the sample contained viral particles consistent with the family Iridoviridae, which allowed further characterization of ranavirus using PCR and DNA sequencing. Similarly, histological examination may reveal structures suggestive of intracellular viral inclusions, and EM can be used to verify the particles are viral origin (Cunningham et al. 1996, 2007; Balseiro et al. 2010; Cheng et al. 2014; Meng et al. 2014). In general, identification is only reliably made at the family (Iridoviridae) level; however, Hyatt et al. (2000, 2002) reported variations in size among members of the family, suggesting that more specific identification might be possible.

As early as the 1980s, cryo-electron microscopy (cryo-EM) has been used to examine the ultrastructure of the surface of viruses (see Adrian et al. 1984). This technique uses rapid freezing of purified virus, thus avoiding alterations from chemical preservatives. During the procedure, multiple photos are taken and reconstructed to yield a 3D image of the virus. Researchers have been using cryo-EM to evaluate the role of various surface proteins in viral assembly and replication (see Yan et al. 2009; Whitley et al. 2010; Tran et al. 2011). It is possible that these findings may provide insight into treatment protocols or vaccine development.

\subsection{Test Validation and Efficiency}

\subsubsection{Gold Standards and Limitations of Diagnostic Tests}

There is no single Gold Standard test for ranavirus, rather the tests vary based upon the question asked. In the case of disease diagnosis, laboratory results should be interpreted in conjunction with knowledge of the clinical status of the animal, pathological findings, and observed population effects. For example, isolation of ranavirus from tissues along with corresponding necropsy findings (gross and histopathological findings) and IHC provides strong evidence supportive of ranavirus as an etiology of death. Similarly, the use of diagnostic tests for surveillance or certification of infection-free individuals or zones requires a statistically valid 
sampling protocol (Gray et al. 2015). Calculation of the sample size required to assess freedom from infection requires knowledge of the minimum expected prevalence and a diagnostic test with known sensitivity and specificity. For example, the prevalence of EHNV infection in rainbow trout can be as low as $4 \%$ (Whittington et al. 1994, 1999). Gray et al. (2015) provide recommendations on sample sizes required to detect ranavirus given a range of assumed infection prevalence.

Given that diagnostic tests (e.g., qPCR) are imperfect, estimating the sensitivity and specificity of tests is important to accurately interpret results. Methods used by laboratories to demonstrate the validity of laboratory test results are outlined in an introductory chapter in The Diagnostic Manual for Aquatic Animal Diseases (OIE 2012a). The OIE guidelines outline the principles of using a laboratory quality management system to ensure that the results of tests are reliable by documenting the complete suite of measures required to minimize and identify false-positive and -negative results. In general, several laboratories working in collaboration can estimate false-positive and -negative results by testing the same samples, which can be used to estimate test sensitivity and specificity. This is accomplished by distributing control samples (i.e., known positive and negative) and standard reagents among laboratories in a blind experimental design, and estimating error rates among laboratories.

\section{Treatment and Vaccine Development}

Treatment and vaccination for ranavirus infection is probably most applicable in captive populations; thus, may be most useful in zoological collections or for conservation programs targeting rare species. Current treatments for ranavirus infection are limited. Allender et al. (2012b) reported the possibility of using guanine analogue antiviral drugs (acyclovir and valacyclovir) to treat chelonians for infection with iridoviruses and herpesviruses. Recently, Li et al. (2014a) reported antiviral activity of DNA aptamers when treating SGIV. Heat treatment is effective at inactivating many pathogens of ectothermic vertebrates such as Batrachochytrium dendrobatidis (Woodhams et al. 2003). However, the effectiveness of heat as a treatment for ranavirus likely varies among host species and viral strains. Rojas et al. (2005) reported that salamanders housed at elevated temperatures $\left(26^{\circ} \mathrm{C}\right)$ were more likely to survive exposure to ATV than those at lower temperatures. Similarly, Allender et al. (2013b) found greater pathogenicity of an FV3-like ranavirus at $22^{\circ} \mathrm{C}$ compared to $28{ }^{\circ} \mathrm{C}$ in red-eared sliders (Trachemys scripta elegans). However, several other studies report faster replication and greater pathogenicity of ranaviruses at warmer temperatures (Whittington and Reddacliff 1995; Grant et al. 2003; Ariel and Jensen 2009; Ariel et al. 2009; Bayley et al. 2013). Given that most ranaviruses do not replicate above $32{ }^{\circ} \mathrm{C}$ (Chinchar 2002; Ariel et al. 2009), elevating body temperature above this threshold may be useful for some host species. Research is needed to determine the effectiveness of heat treatment, duration required for inactivation, and if there is variability among host species and viral strains. 
To date, development of vaccines against iridoviruses has primarily been focused on fish species within the aquaculture industry. Some vaccines are commercially available, yet not applicable to all species or cross-reactive to other iridoviruses ( $\mathrm{Oh}$ et al. 2014). Although live vaccines are often used, DNA vaccines are showing promise. For example, Zhang et al. (2012) found that turbot (Scophthalmus maxi$m u s$ ) vaccinated with DNA vaccines were more likely to survive infection with rock bream iridovirus than unvaccinated fish. Similarly, Caipang et al. (2006) reported evidence of immunity against infection with red seabream iridovirus following administration of a DNA vaccine in red sea bream (Pagrus major). One aspect of vaccination that often limits its use is that it is delivered by intramuscular injection, which is labor intensive. Other researchers have been exploring more feasible delivery methods, such as oral formulations (Tamaru et al. 2006).

\section{Summary Section with Final Recommendations}

Ranaviral disease is devastating to susceptible hosts and causes hemorrhage, ulceration, edema, and organ necrosis. Although lesions vary among classes of ectothermic vertebrates, endothelial cell necrosis with subsequent hemorrhage is one of the changes that occurs across all classes. New technologies have enabled application of diagnostic techniques, such as IHC, that allows us to visualize viral antigens within tissues. Advances in techniques might include laser dissection of lesions followed by IHC and PCR, as well as 3D sequential tomography.

There are limitations to all diagnostic tests; thus, it is important that investigators and researchers use multiple tests for accurate diagnosis, and make the distinction between subclinical infection and disease. The most appropriate test to use is dependent upon the question that needs to be answered. For example, if one wants to determine whether an animal harbors a ranavirus, then PCR, qPCR, IHC, and virus isolation all might provide an answer. Importantly, there is a difference between pathogen detection and determining that a pathogen is associated with the observed clinical disease. There also are different tests recommended for determining prevalence of current or past infection (e.g., qPCR and antibody ELISA, respectively). A typical approach to determine infection status is to apply tests with known sensitivity and specificity to a population using a statistically valid sampling strategy to demonstrate freedom from infection or disease at a minimum expected prevalence (Cameron and Baldock 1998). High throughput qPCR laboratory methodologies are well suited to handle the large sample sizes required for these surveys. However, we still do not have a test that will verify that an individual animal is free from ranavirus infection, especially using nonlethal sampling. For example, if an animal tests positive by PCR but then negative when retested 2 weeks later, it is unknown if the animal has cleared the virus or if the virus remains hidden in the animal's system. Latent infections by ranavirus may be possible (Chapter 6).

We also need a cost-efficient, validated method for detecting and identifying different strains of Ranavirus. Current methods for doing so are not widely available 
and can be cost prohibited; however, future success of reintroduction or translocation programs may hinge on our ability to differentiate between strains within source and destination populations. Likewise, strain identification will be important to include in future ranavirus reporting and mapping programs, as these data can be used in epidemiological studies.

There are many different protocols available for various tests. The OIE has guidelines for standardizing tests among laboratories. With the wide range of host species and sample types encountered during ranavirus studies, it is important to develop and share validation data for diagnostic techniques. We recommend that laboratories studying ranaviruses work together to standardize detection protocols. This task could be accomplished using a ring trial, where blinded samples are tested at many different laboratories internationally. The GRC is an entity that could lead initial discussions on how techniques could be standardize and help facilitate organization of ring trials and coordination of validation data.

There remains much to learn regarding the pathology of ranaviral disease and diagnostic testing for ranavirus infection and disease. Given our current understanding of pathogenesis and recent advances in the genetics of ranavirus and immune response of the host, we should be able to develop effective management and treatment modalities for use in conservation programs, commercial and zoological facilities and aquaria. Further, our understanding of the disease process coupled with our growing knowledge of the ecology and epidemiology of ranaviruses provides a basis for development of management plans for aquatic ecosystems.

Acknowledgements We thank Ana Balseiro and Alex Hyatt for their careful review of this chapter. Open Access publication was made possible through grants provided by the University of Tennessee (Institute of Agriculture, Office of Research and Engagement, and Department of Forestry, Wildlife and Fisheries), Washington State University Libraries, Gordon State College (Office of Academic Affairs), the Association of Reptilian and Amphibian Veterinarians, and the Amphibian and Reptile Conservancy.

Open Access This chapter is distributed under the terms of the Creative Commons Attribution Noncommercial License, which permits any noncommercial use, distribution, and reproduction in any medium, provided the original author(s) and source are credited.

\section{References}

Adrian M, Dubochet J, Lepault J, McDowall AW (1984) Cryo-electron microscopy of viruses. Nature 308:32-36

Ahne W, Schlotfeldt HJ, Thomsen I (1989) Fish viruses: isolation of an icosahedral cytoplasmic deoxyribovirus from sheatfish Silurus glanis. J Vet Med B 36:333-336

Ahne W, Bearzotti M, Bremont M, Essbauer S (1998) Comparison of European systemic piscine and amphibian iridoviruses with epizootic haematopoietic necrosis virus and frog virus 3 . J Vet Med 45:373-383

Allender MC (2012a) Characterizing the epidemiology of ranavirus in North American chelonians: diagnosis, surveillance, pathogenesis, and treatment. Dissertation, University of Illinois at Urbana-Champaign, Urbana-Champaign, p 219 
Allender MC, Fry MM, Irizarry AR, Craig L, Johnson AJ, Jones M (2006) Intracytoplasmic inclusions in circulating leukocytes from an eastern box turtle (Terrepene carolina carolina). J Wildl Dis 42:677-684

Allender MC, Abd-Eldaim M, Schumacher J, McRuer D, Christian LS, Kennedy M (2011) PCR prevalence of Ranavirus in free-ranging eastern box turtles (Terrapene carolina carolina) at rehabilitation centers in three southeastern US states. J Wildl Dis 47:759-764

Allender MC, Mitchell MA, Yarborough J, Cox S (2012) Pharmacokinetics of a single oral dose of acyclovir and valacyclovir in North American box turtles (Terrapene sp). J Vet Pharmacol Ther 36:205-208

Allender MC, Bunick D, Mitchell MA (2013a) Development and validation of Taqman quantitative PCR for detection of frog virus 3-like virus in eastern box turtles (Terrepene carolina carolina). J Virol Methods 188:121-125

Allender MC, Mitchell MA, Torres T, Sekowska J, Riskell EA (2013b) Pathogenicity of frog virus 3-like virus in red-eared slider turtles at two environmental temperatures. J Comp Pathol 149:356-367

Ariel E (1997) Pathology and serological aspects of Bohle iridovirus infections in six selected water-associated reptiles in North Queensland. Ph.D. Dissertation, James Cook University, Townsville City, p 214

Ariel E, Jensen BB (2009) Challenge studies of European stocks of redfin perch, Perca fluviatilis L., and rainbow trout, Oncorhynchus mykiss (Walbaum), with epizootic haematopoietic necrosis virus. J Fish Dis 32(12):1017-1025

Ariel E, Nicolajsen N, Christophersen MB, Holopainen R, Tapiovaara H, Jensen BB (2009) Propagation and isolation of ranaviruses in cell culture. Aquaculture 294:159-164

AVMA (2013) AVMA guidelines for the euthanasia of animals: 2013 edition. American Veterinary Medical Association, Schaumburg, p 102

Balseiro A, Dalton KP, del Cerro A, Marquez I, Cunningham AA, Parra F, Prieto JM, Casais R (2009) Pathology, isolation and molecular characterization of a ranavirus from the common midwife toad Alytes obstetricans on the Iberian Peninsula. Dis Aquat Organ 84:95-104

Balseiro A, Dalton KP, del Cerro A, Marquez I, Parra F, Prieto JM, Casais R (2010) Outbreak of common midwife toad virus in alpine newts (Mesotriton alpestris cyreni) and common midwife toads (Alytes obstetricans) in Northern Spain: a comparative pathological study of an emerging ranavirus. Vet $\mathrm{J}$ 186:256-258

Bang Jensen B, Holopainen R, Tapiovaara H, Ariel E (2011) Susceptibility of pike-perch Sander lucioperca to a panel of ranavirus isolates. Aquaculture 313:24-30

Bayley AE, Hill BJ, Feist SW (2013) Susceptibility of the European common frog Rana temporaria to a panel of ranavirus isolates from fish and amphibian hosts. Dis Aquat Organ 103:171183. doi: $10.3354 /$ dao02574

Beck BH, Bakal RS, Brunner CJ, Grizzle JM (2006) Virus distribution and signs of disease after immersion exposure to largemouth bass virus. J Aquat Anim Health 18:176-183

Becker JA, Tweedie A, Gilligan D, Asmus M, Whittington RJ (2013) Experimental infection of Australian freshwater fish with epizootic haematopoietic necrosis virus (EHNV). J Aquat Anim Health 25:66-76. doi:10.1080/08997659.2012.747451

Beebee T (2012) Impact of Ranavirus on garden amphibian populations. Herpetol Bull 120:1-3

Behncke H, Stöhr AC, Heckers K, Ball I, Marschang RE (2013) Mass-mortality in green striped tree dragons (Japalura splendida) associated with multiple viral infections. Vet Rec 173:248. doi:10.1136/vr.101545

Bollinger TK, Mao J, Schock D, Brigham RM, Chinchar VG (1999) Pathology, isolation, and preliminary molecular characterization of a novel iridovirus from tiger salamanders in Saskatchewan. J Wildl Dis 35:413-429

Brenes R, Gray MJ, Waltzek TB, Wilkes RP, Miller DL (2014a) Transmission of ranavirus between ectothermic vertebrate hosts. PLoS One 9(3):e92476. doi:10.1371/journal. pone. 0092476

Brenes R, Miller DL, Waltzek TB, Wilkes RP, Tucker JL, Chaney JC, Hardman RH, Brand MD, Huether RR, Gray MJ (2014b) Susceptibility of fish and turtles to three ranaviruses isolated 
from different ectothermic vertebrate classes. J Aquat Anim Health 26(2):118-126. doi:10.10 80/08997659.2014.886637

Brunner JL, Schock DM, Davidson EW, Collins JP (2004) Intraspecific reservoirs: complex life cycles and the persistence of a lethal ranavirus. Ecology 85:560-566

Brunner JL, Storfer A, Gray MJ, Hoverman JT (2015) Ranavirus ecology and evolution: from epidemiology to extinction. In: Gray MJ, Chinchar VG (eds) Ranaviruses: lethal pathogens of ectothermic vertebrates. Springer, New York

Bryan LK, Baldwin CA, Gray MJ, Miller DL (2009) Efficacy of select disinfectants at inactivating Ranavirus. Diseases of Aquatic Organisms 84(2):89-94

Burton EC, Miller DL, Styer EL, Gray MJ (2008) Amphibian ocular malformation associated with frog virus 3. Vet J 177:442-444

Bustin SA, Beaulieu JF, Huggett J, Jaggi R, Kibenge FSB, Olsvik PA, Penning LC, Toegel S (2010) MIQE precis: practical implementation of minimum standard guidelines for fluorescence-based quantitative real-time PCR experiments. BMC Mol Biol 11:74. doi:10.1186/1471-2199-11-74

Caipang CMA, Takano T, Hirono I, Aoki T (2006) Genetic vaccines protect red seabream, Pagrus major, upon challenge with red seabream iridovirus (RSIV). Fish Shellfish Immunol 21:130-138

Cameron AR, Baldock FC (1998) A new probability formula for surveys to substantiate freedom from disease. Prev Vet Med 34:1-17

Caraguel CGB, Stryhn H, Gagne N, Dohoo IR, Hammell KL (2011) Selection of a cutoff value for real-time polymerase chain reaction results to fit a diagnostic purpose: analytical and epidemiologic approaches. J Vet Diagn Invest 23:2-15

Cashins S, Skerratt FL, Alford RA (2008) Sodium hypochlorite denatures the DNA of the amphibian chytrid fungus Batrachochytrium dendrobatidis. Dis Aquat Organ 80:63-67

Cheng K, Jones MEB, Jancovich JK, Burchell J, Schrenzel MD, Reavill DR, Imai DI, Urban A, Kirkendall M, Woods LW, Chinchar VG, Pessier AP (2014) Isolation of a Bohle-like iridovirus from boreal toads housed within a cosmopolitan aquarium collection. Dis Aquat Organ 111(2):139-152

Chinchar VG, Metzger DW, Granoff A, Goorha R (1984) Localization of frog virus 3 proteins using monoclonal antibodies. Virology 137:211-216

Chinchar VG (2002) Ranaviruses (family Iridoviridae): emerging cold-blodded killers. Arch Virol 147:447-470

Crane MSJ, Young J, Williams L (2005) Epizootic haematopoietic necrosis virus (EHNV): growth in fish cell lines at different temperatures. Bull Eur Assoc Fish Pathol 25:228-231

Cunningham AA, Langton TES, Bennett PM, Lewin JF, Drury SEN, Gough RE, Macgregor SK (1996) Pathological and microbiological findings from incidents of unusual mortality of the common frog (Rana temporaria). Philos Trans R Soc Lond B Biol Sci 351:1539-1557

Cunningham AA, Hyatt AD, Russell P, Bennett PM (2007) Emerging epidemic diseases of frogs in Britain are dependent on the source of ranavirus agent and the route of exposure. Epidemiol Infect 135:1200-1212. doi:10.1017/S0950268806007679

Cunningham AA, Tems CA, Russell PH (2008) Immunohistochemical demonstration of Ranavirus antigen in the tissues of infected frogs (Rana temporaria) with systemic haemorrhagic or cutaneous ulcerative disease. J Comp Pathol 138:3-11

DeVoe R, Geissler K, Elmore S, Rotstein D, Lewbart G, Guy J (2004) Ranavirus-associated morbidity and mortality in a group of captive eastern box turtles (Terrepene carolina carolina). J Zoo Wildl Med 35:534-543

Docherty DE, Meteyer CU, Wang J, Mao J, Case ST, Chinchar VG (2003) Diagnostic and molecular evaluation of three iridovirus-associated salamander mortality events. J Wildl Dis 39(3):556-566

Duffus AL, Andrews AM (2013) Phylogenetic analysis of a frog virus 3-like ranavirus found at a site with recurrent mortality and morbidity events in southeastern Ontario, Canada: partial major capsid protein sequence alone is not sufficient for fine-scale differentiation. J Wildl Dis 49:464-467 
Duffus ALJ, Waltzek TB, Stöhr AC, Allender MC, Gotesman M, Whittington RJ, Hick P, Hines MK, Marschang RE (2015) Distribution and host range of ranaviruses. In: Gray MJ, Chinchar VG (eds) Ranaviruses: lethal pathogens of ectothermic vertebrates. Springer, New York

Earl JE, Gray MJ (2014) Introduction of ranavirus to isolated wood frog populations could cause local extinction. Ecohealth. doi:10.1007/s10393-014-0950-y

Farnsworth SD, Seigel FA (2013) Responses, movements, and survival of relocate box turtles during construction of the Intercounty Connector Highway in Maryland. J Transp Res 2362:1-8

Forzan MJ, Wood J (2013) Low detection of ranavirus DNA in wild postmetamorphic green frogs, Rana (Lithobates) clamitans, despite previous or concurrent tadpole mortality. J Wildl Dis 49:879-886

Gantress J, Maniero GD, Cohen N, Robert J (2003) Development and characterization of a model system to study amphibian immune responses to iridoviruses. Virology 311:254-262

Geng Y, Wang KY, Zhou ZY, Li CW, Wang J, He M, Yin ZQ, Lai WM (2010) First report of a ranavirus associated with morbidity and mortality in farmed Chinese giant salamanders (Andrias davidianus). J Comp Pathol. doi:10.1016/j.jcpa.2010.11.012

Gold KK, Reed PD, Bemis DA, Miller DL, Gray MJ, Souza MJ (2013) Efficacy of common disinfectants and terbinafine $\mathrm{HCl}$ at inactivating the growth of Batrachochytrium dendrobatiditis in culture. Dis Aquat Organ 107:77-81

Goldberg TL (2002) Largemouth bass virus: an emerging problem for warmwater fisheries? Am Fish Soc Symp 31:411-416

Goodman RM, Miller DL, Ararso YT (2013) Prevalence of ranavirus in Virginia turtles as detected by tail-clip sampling versus oral-cloacal swabbing. Northeastern Nat 20:325-332

Granoff A, Came PE, Breeze DC (1966) Viruses and Renal Carcinoma of Rana Pipiens .I. Isolation and Properties of Virus from Normal and Tumor Tissue. Virology 29:133-148

Grant EC, Philipp DP, Inendino KR (2003) Effects of temperature on the susceptibility of largemouth bass to largemouth bass virus. J Aquat Anim Health 15:215-220

Gray MJ, Miller DL, Schmutzer AC, Baldwin CA (2007) Frog virus 3 prevalence in tadpole populations inhabiting cattle-access and non-access wetlands in Tennessee, U.S.A. Dis Aquat Organ 77:97-103

Gray MJ, Miller DL, Hoverman JT (2009) First report of ranavirus infecting lungless salamanders. Herpetol Rev 40(3):316-319

Gray MJ, Miller DL, Hoverman JT (2012) Reliability of non-lethal surveillance methods for detecting ranavirus infection. Dis Aquat Organ 99:1-6. doi:10.3354/dao02436

Gray MJ, Brunner JL, Earl JE, Ariel E (2015) Design and analysis of ranavirus studies: surveillance and assessing risk. In: Gray MJ, Chinchar VG (eds) Ranaviruses: lethal pathogens of ectothermic vertebrates. Springer, New York

Grayfer L, Edholm E-S, De Jesús Andino F, Chinchar VG, Robert J (2015) Ranavirus host immunity and immune evasion. In: Gray MJ, Chinchar VG (eds) Ranaviruses: lethal pathogens of ectothermic vertebrates. Springer, New York

Green DE, Converse KA, Schrader AK (2002) Epizootiology of sixty-four amphibian morbidity and mortality events in the USA, 1996-2001. Ann NY Acad Sci 969:323-339

Green DE, Gray MJ, Miller DL (2009) Disease monitoring and biosecurity. In: Dodd CK (ed) Amphibian ecology and conservation: a handbook of techniques. Oxford University Press, Oxford

Greer AL, Collins JP (2007) Sensitivity of a diagnostic test for amphibian ranavirus varies with sampling protocol. J Wildl Dis 43:525-532

Greiner M, Gardner IA (2000) Epidemiologic issues in the validation of veterinary diagnostic tests. Prev Vet Med 45:3-22

Grizzle JM, Brunner CJ (2003) Review of largemouth bass virus. Fisheries 28(11):10-14. doi:10.1577/1548-8446(2003)28[10:ROLBV]2.0.CO;2

Grosset C, Wellehan JF, Owens SD, McGraw S, Gaffney PM, Foley J, Childress AL, Yun S, Malm K, Groff JM, Paul-Murphy J, Weber ES (2014) Intraerythrocytic iridovirus in central bearded dragons (Pogona vitticeps). J Vet Diagn Invest 26:354-364 
Haislip NA, Gray MJ, Hoverman JT, Miller DL (2011) Development and disease: how susceptibility to an emerging pathogen changes through anuran development. PLoS ONE 6(7): e22307. Doi:10.1371/journal.pone.

Harp EM, Petranka JW (2006) Ranavirus in wood frogs (Rana sylvatica): potential sources of transmission within and between ponds. J Wildl Dis 42:307-318

Hedrick RP, McDowell TS, Ahne W, Torhy C, De Kinkelin P (1992) Properties of three iridoviruslike agents associated with systemic infections of fish. Dis Aquat Organ 13:203-209

Hengstberger SG, Hyatt AD, Speare R, Coupar BEH (1993) Comparison of epizootic haematopoietic necrosis and Bohle iridoviruses, recently isolated Australian iridoviruses. Dis Aquat Organ 15:93-107

Holopainen R, Ohlemeyer S, Schutze H, Bergmann SM, Tapiovaara H (2009) Ranavirus phylogeny and differentiation based on major capsid protein, DNA polymerase and neurofilament triplet H1-like protein genes. Dis Aquat Organ 85:81-91

Hoverman JT, Gray MJ, Haislip NA, et al. (2011) Phylogeny, life history, and ecology contribute to differences in amphibian susceptibility to ranaviruses. Ecohealth 8:301-319

Huang C, Zhang X, Gin KYH, Qin QW (2004) In situ hybridization of a marine fish virus, Singapore grouper iridovirus with a nucleic acid probe of major capsid protein. J Virol Methods 117:123-128

Hyatt AD, Eaton BT, Hengstberger S, Russel G (1991) Epizootic haematopoietic necrosis virus: detection by ELISA, immunohistochemistry and immunoelectronmicroscopy. J Fish Dis 14:605-617

Hyatt AD, Gould AR, Zupanovic Z, Cunningham AA, Hengstberger S, Whittington RJ, Kattenbelt J, Coupar BEH (2000) Comparative studies of piscine and amphibian iridoviruses. Arch Virol 145:301-331

Hyatt AD, Williamson M, Coupar BEH, Middleton D, Hengstberger SG, Gould AR, Selleck P, Wise TG, Kattenbelt J, Cunningham AA, Lee J (2002) First identification of a ranavirus from green pythons (Chondropython viridis). J Wildl Dis 38(2):239-252

Jancovich JK, Davidson EW, Morado JF, Jacobs BL, Collins JP (1997) Isolation of a lethal virus from the endangered tiger salamander Ambystoma tigrinum stebbinsi. Dis Aquat Organ 31:161-167

Jancovich JK, Davidson EW, Parameswaran N, Mao J, Chinchar VG, Collins JP, Jacobs BC, Storfer A (2005) Evidence for emergence of an amphibian iridoviral disease because of human-enhanced spread. Mol Ecol 14:213-224

Jancovich JK, Steckler N, Waltzek TB (2015a) Ranavirus taxonomy and phylogeny. In: Gray MJ, Chinchar VG (eds) Ranaviruses: lethal pathogens of ectothermic vertebrates. Springer, New York

Jancovich JK, Qin Q, Zhang Q-Y, Chinchar VG (2015b) Ranavirus replication: molecular, cellular, and immunological events. In: Gray MJ, Chinchar VG (eds) Ranaviruses: lethal pathogens of ectothermic vertebrates. Springer, New York

Jaramillo D, Tweedie A, Becker JA, Hyatt A, Crameri S, Whittington RJ (2012) A validated quantitative polymerase chain reaction assay for the detection of ranaviruses (Family Iridoviridae) in fish tissue and cell cultures, using EHNV as a model. Aquaculture 356:186-192

Johnson AJ, Pessier AP, Wellehan JF, Brown R, Jacobson ER (2005) Identification of a novel herpesvirus from a California desert tortoise (Gopherus agassizii). Vet Microbiol 111:107-116

Johnson AJ, Pessier AP, Jacobson ER (2007) Experimental transmission and induction of ranaviral disease in western ornate box turtles (Terrapene ornata ornata) and red-eared sliders (Trachemys scripta elegans). Vet Pathol 44:285-297

Johnson AJ, Pessier AP, Wellehan JFX, Childress A, Norton TM, Stedman NL, Bloom DC, Belzer W, Titus VR, Wagner R, Brooks JW, Spratt J, Jacobson ER (2008) Ranavirus infection of freeranging and captive box turtles and tortoises in the United States. J Wildl Dis 44:851-863

Johnson AJ, Wendland L, Norton TM, Belzer B, Jacobson ER (2010) Development and use of an indirect enzyme-linked immunosorbent assay for detection of iridovirus exposure in gopher tortoises (Gopherus polyphemus) and eastern box turtles (Terrapene carolina carolina). Vet Microbiol 142:160-167 
Kattenbelt JA, Hyatt AD, Gould AR (2000) Recovery of ranavirus dsDNA from formalin-fixed archival material. Dis Aquat Organ 39:151-154

Kik M, Martel A, Spitzen-vander Sluijs A, Pasmans F, Wohlsein P, Grone A, Rijks JM (2011) Ranavirus-associated mass mortality in wild amphibians, The Netherlands, 2010: a first report. Vet J 190:284-286

Langdon JS, Humphrey JD, Williams LM, Hyatt AD, Westbury HA (1986) First virus isolation from Australian fish: an iridovirus-like pathogen from redfin perch, Perca fluviatilis L. J Fish Dis 9:263-268

Li P, Yan Y, Wei S, Weiv J, Gao R, Huang X, Huang Y, Jiang G, Qin Q (2014a) Isolation and characterization of a new class of DNA aptamers specific binding to Singapore grouper iridovirus (SGIV) with antiviral activities. Virus Res 188:146-154

Li W, Zhang X, Weng S, Zhao G, He J, Dong C (2014b) Virion-associated viral proteins of a Chinese giant salamander (Andreas davidianus) iridovirus (genus Ranavirus) and functional study of the major capsid protein (MCP). Vet Microbiol 172:129-139

Ma J, Zeng L, Zhou Y, Jiang N, Zhang H, Fan Y, Meng Y, Xu J (2014) Ultrastructural morphogenesis of an amphibian iridovirus isolated from Chinese giant salamander (Andrias davidianus). J Comp Pathol 150:325-331

Mao J, Hedrick RP, Chinchar VG (1997) Molecular characterization, sequence analysis, and taxonomic position of newly isolated fish iridoviruses. Virology 229:212-220

Mao JD, Green E, Fellers G, Chinchar VG (1999) Molecular characterization of iridoviruses isolated from sympatric amphibians and fish. Virus Res 63:45-52

Marschang RE, Braun S, Becher P (2005) Isolation of a ranavirus from a gecko (Uroplatus fimbriatus). J Zoo Wildl Med 36:295-300

Marsh IB, Whittington RJ, O'Rourke B, Hyatt AD, Chisholm O (2002) Rapid differentiation of Australian, European and American ranaviruses based on variation in major capsid protein gene sequence. Mol Cell Probes 16:137-151

Martínez-Silvestre A, Perpiñán D, Marco I, Lavín S (2002) Venipuncture technique of the occipital venous sinus in freshwater aquatic turtles. J Herpetol Med Surg 12:31-32

Mazzoni R, de Mesquita AJ, Fleury LFF, deBrito WMED, Nunes IA, Robert J, Morales H, Coelho ASG, Barthasson DL, Galli L, Catroxo MHB (2009) Mass mortality associated with a frog virus 3-like Ranavirus infection in farmed tadpoles Rana catesbeiana from Brazil. Dis Aquat Organ 86:181-191

McClenahan SD, Beck BH, Grizzle JM (2005) Evaluation of cell culture methods for detection of largemouth bass virus. J Aquat Anim Health 17:365-372

McLoughlin MF, Graham DA (2007) Alphavirus infections in salmonids-a review. J Fish Dis 30:511-531

Meng Y, Ma J, Jiang N, Zeng LB, Xiao HB (2014) Pathological and microbiological findings from mortality of the Chinese giant salamander (Andrias davidianus). Arch Virol 159:1403-1412. doi:10.1007/s00705-013-1962-6

Miller DL, Rajeev S, Gray MJ, Baldwin C (2007) Frog virus 3 infection, cultured American bullfrogs. Emerg Infect Dis 13:342-343

Miller DL, Rajeev S, Brookins M, Cook J, Whittington L, Baldwin CA (2008) Concurrent infection with Ranavirus, Batrachochytrium dendrobatidis, and Aeromonas in a captive anuran colony. J Zoo Wildl Med 39:445-449

Miller DL, Gray MJ (2010) Amphibian decline and mass mortality: The value of visualizing ranavirus in tissue sections. The Veterinary Journal 186:133-134

Miller DL, Gray MJ, Strofer A (2011) Ecopathology of ranaviruses infecting amhibians. Viruses 3:2351-2373. doi: $10.3390 / \mathrm{v} 3112351$

Monini M, Ruggeri FM (2002) Antigenic peptides of the epizootic hematopoietic necrosis virus. Virology 297:8-18

Oh SY, Oh MJ, Nishizawa T (2014) Potential for a live red seabream iridovirus (RSIV) vaccine in rock bream Oplegnathus fasciatus at a low rearing temperature. Vaccine 32:363-368

OIE (2012a) Chapter 1.1.2 Principles and methods of validation of diagnostic assays for infectious diseases. In: Manual of diagnostic tests for aquatic animals (World Organisation for Animal Health) http://www.oie.int/international-standard-setting/aquatic-manual/access-online/ 
OIE (2012b) Chapter 2.1.2 Quality management in veterinary testing laboratories (World Organisation for Animal Health). In: Manual of diagnostic tests for aquatic animals. http:// www.oie.int/international-standard-setting/aquatic-manual/access-online/

OIE (2012c) Chapter 2.3.1 Epizootic Haematopoietic necrosis. In: Manual of diagnostic tests for aquatic animals (World Organisation for Animal Health). http://www.oie.int/internationalstandard-setting/aquatic-manual/access-online/

OIE (2012d) Chapter 2.1.2 Infection with ranavirus. In: Manual of diagnostic tests for aquatic animals (World Organisation for Animal Health). http://www.oie.int/international-standardsetting/aquatic-manual/access-online/

Pallister J, Gould A, Harrison D, Hyatt A, Jancovich J, Heine H (2007) Development of real-time PCR assays for the detection and differentiation of Australian and European ranaviruses. J Fish Dis 30:427-438

Pessier AP, Mendelson JR (2010) A manual for control of infectious diseases in amphibian survival assurance colonies and reintroduction programs. IUCN/SSC Captive Breeding Specialist Group, Apple Valley, MN

Petranka JW, Murray SM, Apple Valley MN, Kennedy CA (2003) Response of amphibians to restoration of a southern Appalachian wetland: perturbations confound post-restoration assessment. Wetlands 23:278-290

Picco AM, Brunner JL, Collins JP (2007) Susceptibility of the endangered California tiger salamander, Ambystoma californiense, to ranavirus infection. J Wildl Dis 43:286-290

Plumb JA, Grizzle JM, Young HE, Noyes AD, Lamprecht S (1996) An iridovirus isolated from wild largemouth bass. J Aquat Anim Health 8:265-270

Pozet F, Morand M, Moussa A, Torhy C, de Kinkelin P (1992) Isolation and preliminary characterization of a pathogenic icosahedral deoxyribovirus from the catfish Ictalurus melas. Dis Aquat Organ 14:35-42

Price, SJ, Garner TWJ, Nichols RA, et al. (2014) Collapse of amphibian communities due to an introduced Ranavirus. Curr Biol 24:2586-2591. http://www.cell.com/currentbiology/pdfExtended/S0960-9822(14)01149-X

Qin QW, Chang SF, Ngoh-Lim GH, Gibson-Kueh S, She C, Lam TJ (2003) Characterization of a novel ranavirus isolated from grouper Epinephelus tauvina. Dis Aquat Organ 53:1-9

Reddacliff LA, Whittington RJ (1996) Pathology of epizootic haematopoietic necrosis virus (EHNV) infection in Rainbow Trout (Oncorhynchus mykissWalbaum) and Redfin Perch (Perca fluviatilis L.). J Comp Pathol 115:103-115

Rimmer AE, Becker JA, Tweedie A, Whittington RJ (2012) Validation of high throughput methods for tissue disruption and nucleic acid extraction for ranaviruses (family Iridoviridae). Aquaculture 338:23-28

Rivera S, Wellehan JF, McManamon R, Innis CJ, Garner MM, Raphael BL, Gregory CR, Latimer KS, Rodriguez CE, Diaz-Figueroa O, Marlar AB, Nyaoke A, Gates AE, Gilbert K, Childress AL, Risatti GR, Frasca S (2009) Systemic adenovirus infection in Sulawesi tortoises (Indotestudo forsteni) caused by a novel siadenovirus. J Vet Diagn Invest 21:415-426

Robert J, Abramowitz L, Gantress J, Morales HD (2007) Xenopus laevis: a possible vector of ranavirus infection? J Wildl Dis 43:645-652

Robert J, George E, De Jesús AF, Chen G (2011) Waterborne infectivity of the ranavirus frog virus 3 in Xenopus laevis. Virology 417(2):410-417

Rojas S, Richards K, Jancovich JK, Davidson E (2005) Influence of temperature on Ranavirus infection in larval salamanders Ambystoma tigrinum. Dis Aquat Organ 63:95-100

Rothermel BB, Travis ER, Miller DL, Hill RL, McGuire JL, Yabsley MJ (2013) High occupancy of stream salamanders despite high Ranavirus prevalence in a Southern Appalachians Watershed. Ecohealth 10:184-189

Ruder MG, Allison AB, Miller DL, Keel MK (2010) Pathology in practice: ranaviral disease in a box turtle. J Am Vet Med Assoc 237:783-785

Schloegel LM, Daszak P, Cunningham AA, Speare R, Hill B (2010) Two amphibian diseases, chytridiomycosis and ranaviral disease, are now globally notifiable to the World Organization for Animal Health (OIE): an assessment. Dis Aquat Organ 92:101-108 
Schock DM, Bollinger TK, Chinchar VG, Jancovich JK, Collins JP (2008) Experimental evidence that amphibian ranaviruses are multi-host pathogens. Copeia 2008:133-143

Steiner KA, Whittington RJ, Petersen RK, Hornitzky C, Garnet H (1991) Purification of epizootic hematopoietic necrosis virus and its detection using ELISA. J Virol Methods 33:199-210

Stöhr AC, Blahak S, Heckers KO, Wiechert J, Behncke H, Mathes K, Gunther P, Zwart P, Ball I, Marschang RE RB (2013) Ranavirus infections associated with skin lesions in lizards. Vet Res 44:84, http://www.veterinaryresearch.org/content/44/1/84

Sutton WB, Gray MJ, Hardman RH, Wilkes RP, Kouba A, Miller DL (2014a) High susceptibility of the endangered dusky gopher frog to ranavirus. Dis Aquat Organ 112(1):9-16

Sutton WB, Gray MJ, Hoverman JT, Secrist RG, Super P, Hardman RH, Tucker JL, Miller DL (2014b) Trends in ranavirus prevalence among plethodontid salamanders in the Great Smoky Mountains National Park. Ecohealth, doi:10.1007/s10393-014-0994-z

Tamaru Y, Ohtsuka M, Kato K, Manabe S, Kuroda K, Sanada M, Ueda M (2006) Application of the arming system for the expression of the 380R antigen from red sea bream iridovirus (RSIV) on the surface of yeast cells: a first step for the development of an oral vaccine. Biotechnol Prog 22:949-953

Teacher AGF, Cunningham AA, Garner WJ (2010) Assessing the long-term impact of ranavirus infection in wild common frog populations. Anim Conserv 13:514-522

Todd-Thompson M (2010) Seasonality, variation in species prevalence, and localized disease for ranavirus in Cades Cove (Great Smoky Mountains National Park) amphibians. Master Thesis, University of Tennessee, Knoxville. http://trace.tennessee.edu/utk_gradthes/665. Accessed 2 Sep 2014

Tran BN, Chen L, Liu Y, Wu J, Velazquez-Campoy A, Sivaraman J, Hew CL (2011) Novel histone H3 binding protein ORF158L from the Singapore grouper iridovirus. J Virol 85:9159-9166. doi:10.1128/JVI. 02219-10

Waltzek TB, Miller DL, Gray MJ, Drecktrah B, Briggler JT, MacConnell B, Hudson C, Hopper L, Friary J, Yun SC, Malm KV, Weber ES, Hedrick RP (2014) Expansion of the host range of frog virus 3 into hatchery-reared pallid sturgeon Scaphirhynchus albus. Dis Aquat Organ 111:219-227. doi: 10.3354/dao02761

Weir RP, Moody NJ, Hyatt AD, Crameri S, Voysey R, Pallister J, Jerrett IV (2012) Isolation and characterization of a novel Bohle-like virus from two frog species in the Darwin rural area, Australia. Dis Aquat Organ 99:169-177

Wellehan JFX, Strik NI, Stacy BA, Childress AL, Jacobson ER, Telford SR (2008) Characterization of an erythrocytic virus in the family Iridoviridae from a peninsula ribbon snake (Thamnophis sauritus sackenii). Vet Microbiol 131:115-122

Wheelwright NT, Gray MJ, Hill RD, Miller DL (2014) Sudden mass die-off of a large population of wood frog (Lithobates sylvaticus) tadpoles in Maine, USA, likely due to ranavirus. Herpetol Rev 45:240-242

Whitley DS, Yu K, Sample RC, Sinning A, Henegar J, Norcross E, Chinchar VG (2010) Frog virus 3 ORF 53R, a putative myristoylated membrane protein, is essential for virus replication in vitro. Virology 405:448-456

Whittington R, Deece K (2004) Aquatic animal health subprogram: development of diagnostic and reference reagents for epizootic haematopoietic necrosis virus of finfish. The University of Sydney and Fisheries Research and Development Corporation, Sydney and Canberra

Whittington RJ, Reddacliff GL (1995) Influence of environmental temperature on experimental infection of redfin perch (Perca fluviatilis) and rainbow trout (Oncorhynchus mykiss) with epizootic haematopoietic necrosis virus, an Australian iridovirus. Aust Vet J 72:421-424

Whittington RJ, Steiner KA (1993) Epizootic haematopoietic necrosis virus (EHNV): improved ELISA for detection in fish tissues and cell cultures and an efficient method for release of antigen from tissues. J Virol Methods 43:205-220

Whittington RJ, Philbey A, Reddacliff GL, Macgown AR (1994) Epidemiology of epizootic haematopoietic necrosis virus (EHNV) infection in farmed rainbow trout, Oncorhynchus mykiss (Walbaum): findings based on virus isolation, antigen capture ELISA and serology. J Fish Dis 17:205-218 
Whittington RJ, Speare R (1996) Sensitive detection of serum antibodies in the cane toad Bufo marinus. Dis Aquat Organ 26:59-65

Whittington RJ, Kearns C, Speare R (1997) Detection of antibodies against iridoviruses in the serum of the amphibian Bufo marinus. J Virol Methods 68:105-108

Whittington RJ, Reddacliff LA, Marsh I, Kearns C, Zupanovic Z, Callinan RB (1999) Further observations on the epidemiology and spread of epizootic haematopoietic necrosis virus (EHNV) in farmed rainbow trout (Oncorhynchus mykiss) in southeastern Australia and a recommended sampling strategy for surveillance. Dis Aquat Organ 35:125-130

Whittington RJ, Becker JA, Dennis MM (2010) Iridovirus infections in finfish-critical review with emphasis on ranaviruses. J Fish Dis 33:95-122. doi:10.1111/j.1365-2761.2009.01110.x

Wolf K, Bullock GL, Dunbar CE, Quimby MC (1968) Tadpole edema virus: a viscerotropic pathogen for anuran amphibians. J Infect Dis 118:253-262

Woodhams DC, Alford RA, Marantelli G (2003) Emerging disease of amphibians cured by elevated body temperature. Dis Aquat Organ 55:65-67

Yan X, Yu Z, Zhang P, Battisti AJ, Holdaway HA, Chipman PR, Bajaj C, Bergoin M, Rossmann MG, Baker TS (2009) The capsid proteins of a large, icosahedral dsDNA virus. J Mol Biol 385:1287-1299. doi:10.1016/j.jmb.2008.11.002

Yuan JS, Reed A, Chen F, Stewart CN (2006) Statistical analysis of real-time PCR data. BMC Bioinformatics 7:85. doi:10.1186/1471-2105-7-85

Zhang M, Hu YH, Ziao ZZ, Sun Y, Sun L (2012) Construction and analysis of experimental DNA vaccines against megalocytivirus. Fish Shellfish Immunol 33:1192-1198

Zilberg D, Grizzle JM, Plumb JA (2000) Preliminary description of lesions in juvenile largemouth bass injected with largemouth bass virus. Dis Aquat Organ 39:143-146

Zupanovic Z, Lopez G, Hyatt AD, Green B, Bartran G, Parkes H, Whittington RJ, Speare R (1998) Giant toads Bufo marinus in Australia and Venezuela have antibodies against 'ranaviruses'. Dis Aquat Organ 32:1-8 


\title{
Design and Analysis of Ranavirus Studies: Surveillance and Assessing Risk
}

\author{
Matthew J. Gray, Jesse L. Brunner, Julia E. Earl, and Ellen Ariel
}

\section{Introduction}

There is mounting evidence that ranaviruses can impact populations of ectothermic vertebrate species, and may contribute to species declines (Teacher et al. 2010; Earl and Gray 2014; Price et al. 2014). Studies can be designed to determine the distribution and prevalence of ranavirus, the risk of introducing the pathogen into an uninfected area, and its possible effects on populations. Properly designed studies rely on a combination of field data, laboratory experiments, and quantitative analyses, which typically require teams of experts with adequate resources. The financial cost to assess the risk of ranaviruses can be substantial. For example, Project RANA (Risk assessment of new and emerging systemic iridoviral diseases for European fish and aquatic ecosystems) cost approximately 1.4 M € (in 2012; Evira 2013). Similarly, the Maryland Department of Natural Resources (MDNR) is currently performing a surveillance study across seven US states for $\$ 178,000$ (in 2014 USD; Smith et al. 2014). According to the Global Ranavirus Consortium (GRC) website, average cost of genomic DNA (gDNA) extraction and quantitative PCR to test for ranavirus is about \$25 USD (in 2014)

\footnotetext{
M.J. Gray $(\bowtie)$

Center for Wildlife Health, Department of Forestry, Wildlife and Fisheries, University of Tennessee, 274 Ellington Plant Sciences Building, Knoxville, TN 37996-4563, USA e-mail: mgray11@utk.edu

\section{J.L. Brunner}

School of Biological Sciences, Washington State University, Pullman, WA 99164-4236, USA

J.E. Earl

National Institute for Mathematical and Biological Synthesis, University of Tennessee, Knoxville, TN 37996-3410, USA

E. Ariel

College of Public Health, Medical and Veterinary Sciences, James Cook University, Townsville, QLD 4811, Australia
} 
per sample (http://www.ranavirus.org/). Considering that adequate sample sizes to detect ranavirus and obtain precise estimates of infection prevalence can be high $(n>60)$, laboratory expenses associated with ranavirus testing are substantial. Costs for mobilizing field crews over large geographic regions are also considerable. For example, over $95 \%$ of the MDNR's budget for the above study was dedicated to personnel, field supplies, and travel. Thus, organizations that are interested in assessing the risk of ranaviruses in wild and captive populations should be prepared to invest adequate resources. Significant planning also is essential to ensure that sufficient sample sizes are collected, contamination of samples is minimized (Miller et al. 2015), and that the information collected leads to intended measurable deliverables. For organizations that have limited knowledge about ranaviruses in their region, it may take several years to document the distribution of ranaviruses, identify infection hotspots, and implement disease intervention strategies that thwart the introduction of ranavirus or reduce its prevalence. This chapter provides the basics for designing studies to assess the risk of ranavirus. In addition, we encourage organizations to collaborate with experts that have been studying ranaviruses. The GRC can provide information on ranavirus experts in your region.

\section{Ranavirus Surveillance}

The emergence of infectious diseases has mobilized universities and organizations to determine the risk of pathogens in wild populations. To quantify risk, a fundamental understanding of the host-pathogen system at molecular (Jancovich et al. 2015a) and organismal levels (Brunner et al. 2015) is essential. The assessment of risk often starts with determining whether a pathogen is emerging, which means the pathogen is increasing in geographic distribution, prevalence in a population, or host range (Wobeser 2006). In this chapter, we refer to an outbreak as an increase in ranavirus occurrence beyond background levels, which are often unknown. Because estimates of infection prevalence and incidence are used to make decisions about risk, pathogen surveillance programs are commonly employed. If designed properly, surveillance programs can be effective at detecting pathogens, obtaining precise estimates of prevalence and incidence, and providing the necessary data to determine if a pathogen is a threat to a population or species.

\subsection{Interpreting Infection Data}

Increasingly, ranavirus infections are detected using PCR-based methods, but other methods are also important for directly detecting the virus (i.e., isolation in cell culture, electron microscopy, antigen capture ELISA) or evidence of infection 
(e.g., histology, serologic methods; Miller et al. 2015). Estimates of viral load via quantitative PCR or cell culture-based methods (i.e., plaque assays or $50 \%$ tissue culture infective dose $\left[\mathrm{TCID}_{50}\right]$ ), along with other diagnostic tools (e.g., histology), can provide information on the intensity or severity of infection and disease (Miller et al. 2015). It is important to understand what each of these methods detects (e.g., PCR detects the presence of ranavirus DNA while isolation of a virus with cell culture demonstrates the presence of infectious virions, Miller et al. 2015), as well as to recognize the limitations of each. The ability to detect an infection generally increases with time since pathogen exposure, severity of the infection, and the sensitivity of the method (Miller et al. 2015). If the assay's sensitivity and specificity are known, these values should be used to adjust estimates of prevalence and incidence; if they are not known, one should interpret infection data conservatively.

The most common variables measured during surveillance studies are infection prevalence and incidence. Infection prevalence is the number of individuals infected divided by the sample size, and it estimates the proportion of the population that is infected at a particular time. A related variable is seroprevalence, which estimates the proportion of the population that has serologic evidence of prior exposure to the pathogen. Incidence, on the other hand, is the rate at which individuals become infected over a specified time period (Wobeser 2006). While it is often expressed as the number of new cases per unit time, it is generally more useful to present as per capita incidence (e.g., per 1,000 individuals at risk).

While prevalence is more commonly estimated than incidence during surveillance studies, it is simply a "snap shot" of the infection burden at a given time so it is difficult to interpret in the absence of biological context. An understanding of the relative susceptibility of species to ranavirus can help interpret prevalence data. For example, if experimental exposures show that a species dies rapidly following ranavirus exposure, then high prevalence would be most consistent with sampling during the peak of an epidemic. Several studies have reported species-level susceptibility under controlled conditions (e.g., Hoverman et al. 2011; Brenes et al. 2014b; Brunner et al. 2015). Biological context also can be gleaned from the density of the population and the timing of the survey relative to the phenology of the organism. For example, observing low prevalence and a dense population of amphibian larvae early in spring would be more consistent with the virus recently being introduced rather than an outbreak already occurring.

Several surveillance studies suggest background prevalence levels for ranavirus in amphibian and chelonian populations is $<5 \%$ (e.g., Todd-Thompson 2010; Hoverman et al. 2012; Allender et al. 2006; Forzán and Wood 2013; Hamed et al. 2013; Sutton et al. 2014). Given the apparent correlation between disease-related mortality and infection prevalence with FV3-like ranaviruses (Haislip et al. 2011; Hoverman et al. 2011; Brenes et al. 2014b), Gray and Miller (2013) suggested that prevalence $>40 \%$ in amphibian populations might signal that an outbreak is occurring. Although these rules of thumb may be useful in interpreting prevalence levels, we urge caution in interpreting prevalence data outside of the broader biological 
context. It is also worth noting that ranavirus die-offs can occur quickly ( $<2$ weeks; Todd-Thompson 2010; Waltzek et al. 2014), so frequent sampling is necessary to detect and understand the epizootiology of ranaviruses.

Lastly, it is important to recognize that infected individuals may be more or less likely to be detected or captured than uninfected individuals, which can bias prevalence estimates (Cooch et al. 2012). For instance, moribund fish and tadpoles are often found near the surface thus can be detected easily and inflate prevalence, whereas sick turtles may move less and have lower detection probabilities resulting in underestimates of prevalence. Variation in detection probabilities through time (e.g., developmental stages) and among locations also can lead to apparent differences in prevalence that do not reflect actual differences in the proportion infected. While we are unaware of any ranavirus surveillance studies that accounted for detection probabilities, we think that doing so will substantially improve our understanding of ranavirus biology.

Infection prevalence is useful when describing the distribution of ranaviruses among regions and host species, but it does not convey information about risk or rates of infection. Infection incidence is the rate at which individuals become infected with a pathogen (i.e., the number of new cases that occur in a specified time period; Wobeser 2006). In small captive populations, it may be possible to determine how many individual animals become infected over short intervals. For example, if an initial survey found that 2 of 50 animals were infected and a second survey at the end of the month found that ten individuals were infected, then the incidence was $16.7 \%$ (=8 new cases $/ 48$ at risk) per month. Note that individuals infected at the beginning of a study are not at risk of developing the infection so they are not included when estimating incidence. If populations are not closed (i.e., immigration or emigration occurs), calculations of incidence rates need to be adjusted for the time at risk (i.e., see Dohoo et al. 2003 for details).

Estimating incidence in wild populations is difficult, because we generally cannot track the fate or infection status of individuals. Two approaches are often used to estimate infection incidence in wild populations. First, sentinels can be used, which are uninfected individuals that are introduced into the environment (e.g., tadpoles in cages placed in a pond) and regularly screened for infection. Sentinel species should be highly susceptible to ranavirus, such as the wood frog (Lithobates sylvaticus) in North America (Hoverman et al. 2011). A second approach is capturemark reencounter (CMR) studies where individuals are given unique marks and released. During subsequent encounter periods (e.g., trapping, netting), the researcher records the new and recaptured individuals, and determines their infection status. Given that individuals are released, infection status must be determined using nonlethal methods (St-Amour and Lesbarrères 2007; Gray et al. 2012). Ultimately, CMR models estimate the probability of individuals changing infection status while accounting for imperfect detection of the pathogen and imperfect recapture probability of the host. 


\subsection{Planning Surveillance}

Cross-sectional studies that sample multiple populations during one time period are most appropriate for understanding the distribution of ranaviruses, while longitudinal studies that sample the same populations through time are most useful in understanding the epidemiology of ranaviruses and their impacts on populations. For organizations starting surveillance programs, we recommend starting with a crosssectional study that involves widespread sampling across multiple taxa with the goal of identifying locations with elevated levels of ranavirus infection. If funding is limited, species with known high susceptibility to ranavirus or species of conservation concern can be targeted. Lethal samples (i.e., organ tissue) will likely result in greater detection of ranavirus compared to nonlethal samples (i.e., swabs, tailclips; Gray et al. 2012). Once populations or sites with high ranavirus prevalence are identified, a more intensive longitudinal study can be performed that involves frequent sampling through the annual cycle to understand seasonal and annual trends. Sampling once every 2 weeks while hosts are present should be sufficient to detect most outbreaks (Todd-Thompson 2010).

Ranavirus outbreaks can occur because of natural or anthropogenic factors (Gray et al. 2009). Some known natural factors are host density, species composition, temperature, and host development (Gray et al. 2009; Brunner et al. 2015). Anthropogenic factors could be related to stressors (e.g., pesticides, Kerby et al. 2011) or the introduction of novel isolates (i.e., pathogen pollution, Storfer et al. 2007). Thus, to identify the causal factors for outbreaks, ideally host densities and stages of development, water and ambient temperature, and water quality should be measured during surveillance programs. If ranavirus is detected, it can be isolated from fresh or frozen tissue (Miller et al. 2015), and genomic comparisons can reveal whether it is a novel isolate that was potentially introduced (Jancovich et al. 2015b).

Understanding the impacts of ranavirus on populations is a fundamental conservation question (Duffus et al. 2015). Sampling the same sites over several years is necessary to understand possible population impacts (e.g., Price et al. 2014). In addition to sampling individuals for ranavirus infection, mark-recapture methods (e.g., Jolly-Seber) can be used to estimate host population size (Williams et al. 2002). Estimates of prevalence, incidence rate, and host abundance are essential to make informed decisions on ranavirus impacts and to identify causes of outbreaks so intervention strategies can be implemented.

\section{Study Design}

When designing a surveillance study, sites to be sampled should be selected randomly unless certain sites need to be targeted because they are of key conservation interest. Random sampling could be stratified based on different geographic areas or 
a hypothesis related to ranavirus emergence, such as human land-use (e.g., agricultural vs. forested). Random site selection avoids unintentional biases and potential confounding factors. For instance, sites that are easily accessed will be easier to sample, but may also have greater rates of visitation by others (e.g., people fishing), which could increase rates of ranavirus introduction or levels of stressors. The number of sites sampled will depend on the study's objectives and available resources. Clearly, as number (and spatial extent) of sites increases, your conclusions will be more general. However, there also is merit in performing intensive sampling at a few sites, especially those with known reoccurring die-offs.

When sampling, individuals should be randomly collected. Ideally, captured individuals should be placed into separate numbered containers, and the individuals that are processed should be selected using a random numbers table or statistical software. Individuals should not be cohoused because transmission of ranavirus can occur rapidly between them (Brunner et al. 2007; Robert et al. 2011). Another approach is to process individuals as they are captured until a target sample size is met. Importantly, individuals that are processed should not be haphazardly selected from a group, because bias can be introduced (Gotelli and Ellison 2004). If morbid individuals are observed, they can be targeted for diagnostic purposes (Miller et al. 2015); however, targeting individuals with possible gross signs of ranaviral disease may overestimate prevalence or incidence rate. Alternatively, if the goal of surveillance is to declare a site as "ranavirus-free" (Sect. 7), targeting apparently morbid individuals can increase the probability of detecting the pathogen.

Lastly, surveillance studies in wild populations are important to learn about the distribution of ranavirus and effects on host populations. However, identifying factors responsible for outbreaks in wild populations can be challenging. Laboratory and mesocosm studies can be useful in identifying natural and anthropogenic factors that facilitate emergence. Information from controlled studies can be used to design surveillance studies that target certain hypotheses for ranavirus emergence. Additionally, controlled studies can inform field personnel of factors that should be measured (e.g., water quality) in conjunction with infection status and population abundance.

\section{Required Sample Size}

Determining the number of samples that need to be collected is generally a first step in designing a surveillance project. Required sample size will depend on whether your goal is to (1) detect the pathogen or (2) obtain a precise estimate of prevalence that can be used for statistical inferences. To estimate sample size necessary to detect a pathogen, you need (1) a previous estimate or assumed level of prevalence, (2) estimate of host population size, and (3) a specified level of confidence (generally $95 \%$ ) in detecting the pathogen (Amos 1985; Thoesen 1994). As prevalence of 
Table 1 Required sample size ${ }^{a}$ to detect ranavirus in a host population with $95 \%$ confidence given the population size and assumed infection prevalence

\begin{tabular}{l|l|l|l|r}
\hline \multirow{2}{*}{ Estimated population size } & \multicolumn{4}{l}{ Assumed infection prevalence of ranavirus } \\
\cline { 2 - 5 } & $20 \%$ & $10 \%$ & $5 \%$ & $2 \%$ \\
\hline 50 & 5 & 20 & 35 & 50 \\
\hline 100 & 8 & 23 & 45 & 75 \\
\hline 250 & 11 & 25 & 50 & 110 \\
\hline 500 & 13 & 26 & 55 & 130 \\
\hline 2,000 & 15 & 27 & 60 & 145 \\
\hline$>100,000$ & 15 & 30 & 60 & 150 \\
\hline
\end{tabular}

${ }^{\mathrm{a} C a l c u l a t e d ~ f o l l o w i n g ~ m e t h o d o l o g y ~ i n ~ A m o s ~(1985) ~ a n d ~ T h o e s e n ~(1994) ~}$

the pathogen decreases and host population increases, the sample size required to detect a pathogen increases (Table 1). Thus, a small sample size $(n \leq 10)$ is required to detect an outbreak of ranavirus; however, a large sample size is required $(n=35-150)$ to detect ranavirus if prevalence is low $(\leq 5 \%)$. In general, we recommend a minimum sample size of 30 per site for widespread surveillance projects that are attempting to detect ranavirus (Table 1). Larger sample sizes should be collected at sites of concern where precise estimates are needed to identify factors associated with emergence.

Determining the required sample size to obtain a precise estimate of prevalence requires: (1) a previous estimate of prevalence $(\hat{p}),(2)$ a specified level of error $(d)$ that you are willing to tolerate in the estimate of prevalence, and (3) a specified level of confidence in the prevalence estimate (generally $95 \%$ ). Sample size can be estimated as,

$$
n=\hat{p}(1-\hat{p})\left[\frac{1.96}{d}\right]^{2} \text {, }
$$

where 1.96 is the critical value for the standard normal curve at $95 \%$ confidence. If a previous estimate of $\hat{p}$ is unavailable, $\hat{p}=0.5$ can be used. Thus, if $\hat{p}=0.85$ and $d=0.05$, required $n=196$. However, if you are willing to accept a larger error in estimating $\hat{p}$ (e.g., $10 \%=0.10$ ), required $n=49$ when $\hat{p}=0.85$. Additionally, as $p$ approaches 0.5 , the required sample size for a precise estimate of $\hat{p}$ increases. In the previous example where $d=0.10$, required $n=96$ for $\hat{p}=0.5$.

Detecting differences in prevalence between two sites with a statistical test can require a large sample size (Table 2). For example, required $n=219-408$ per site to detect a $10 \%$ difference in prevalence between two sites with $95 \%$ confidence $(\alpha)$ and statistical power $(\beta)=80 \%$ depending on the value of the two proportions. Several websites (http://epitools.ausvet.com.au/content.php?page=2Proportions) and software packages are available for planning required sample size considering 


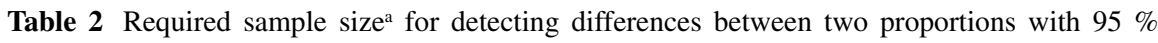
confidence $(\alpha=0.05)$ and $80 \%$ statistical power $(\beta=0.80)$

\begin{tabular}{|c|c|c|c|c|c|c|c|c|c|c|c|}
\hline \multirow{2}{*}{$\begin{array}{c}\text { Proportion } \\
1\end{array}$} & \multicolumn{11}{|c|}{ Proportion 2} \\
\hline & 0.05 & 0.1 & 0.2 & 0.3 & 0.4 & 0.5 & 0.6 & 0.7 & 0.8 & 0.9 & 0.95 \\
\hline 0.05 & & 474 & 88 & 43 & 27 & 19 & 14 & 11 & 8 & 7 & 6 \\
\hline 0.1 & 474 & & 219 & 72 & 38 & 25 & 17 & 13 & 10 & 8 & 7 \\
\hline 0.2 & 88 & 219 & & 313 & 91 & 45 & 28 & 19 & 13 & 10 & 8 \\
\hline 0.3 & 43 & 72 & 313 & & 376 & 103 & 49 & 29 & 19 & 13 & 11 \\
\hline 0.4 & 27 & 38 & 91 & 376 & & 408 & 107 & 49 & 28 & 17 & 14 \\
\hline 0.5 & 19 & 25 & 45 & 103 & 408 & & 408 & 103 & 45 & 25 & 19 \\
\hline 0.6 & 14 & 17 & 28 & 49 & 107 & 408 & & 376 & 91 & 38 & 27 \\
\hline 0.7 & 11 & 13 & 19 & 29 & 49 & 103 & 376 & & 313 & 72 & 43 \\
\hline 0.8 & 8 & 10 & 13 & 19 & 28 & 45 & 91 & 313 & & 219 & 88 \\
\hline 0.9 & 7 & 8 & 10 & 13 & 17 & 25 & 38 & 72 & 219 & & 474 \\
\hline 0.95 & 6 & 7 & 8 & 11 & 14 & 19 & 27 & 43 & 88 & 474 & \\
\hline
\end{tabular}

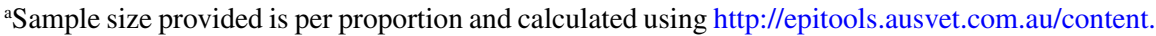
php?page $=2$ Proportions

the minimum detectable difference between proportions, $\alpha$ and $\beta$. Required sample size decreases as the minimum detectable difference increases, and confidence level and power of a statistical test decrease.

\section{Data Analysis}

\subsection{Confidence Intervals}

Even with large sample sizes, there is uncertainty associated with any estimate of prevalence or incidence. Confidence intervals are a common measure of conveying the degree of certainty in these estimates. They can also be used to statistically compare estimates of prevalence, where nonoverlapping confidence intervals imply a statistical difference. To construct a confidence interval for incidence, the proportion is divided by the time interval.

A common approach to estimating confidence intervals is based on the standard normal approximation. This process involves calculating the standard error of a proportion, multiplying by the critical value associated with $95 \%$ confidence for the standard normal distribution (1.96), and adding and subtracting this product from the sample estimate for prevalence (Brown et al. 2001):

$$
\hat{p} \pm 1.96 \sqrt{\frac{\hat{p}(1-\hat{p})}{n}}
$$

This approximation should only be used if sample size is large $(n>20)$ and $0.10<\hat{p}<0.90$; otherwise, confidence intervals can extend beyond 0 and 1 , which is nonsensical (Brown et al. 2001). 
There are several better methods for estimating confidence intervals for proportions (reviewed in Brown et al. 2001). We recommend the Wilson score interval (Wilson 1927), because it performs well at lower sample sizes, when $\hat{p}$ is near 0 or 1 , and it is not overly conservative (as with some continuity correction methods). The equation is:

$$
\frac{1}{1+\frac{1.96^{2}}{n}}\left[\hat{p}+\frac{1.96^{2}}{2 n} \pm 1.96 \sqrt{\frac{1}{n}} \hat{p}(1-\hat{p})+\frac{1.96^{2}}{4 n^{2}}\right]
$$

with the same variables as (2). Hand calculation can be time consuming; however, many statistical packages estimate the Wilson score interval (e.g., the R package "binom") and some websites are available (http://vassarstats.net/prop1.html). Appendix 1 provides example code in $\mathrm{R}$ for estimating confidence intervals.

\subsection{Comparing Proportions}

While it is useful to describe the degree of confidence in an estimate of prevalence or incidence, we are more often interested in comparing these estimates between groups or populations. Chi-square tests are often used to compare proportions among populations; the most common is the Pearson's chi-squared test:

$$
\chi^{2}=\sum_{i=1}^{n} \frac{\left(O_{i}-E_{i}\right)^{2}}{E_{i}}
$$

where $O_{i}$ is the observed number of infections for population $i$, and $E_{i}$ is the expected number of infections for population $i$ according to the null hypothesis. Generally, the null hypothesis is that infection prevalence is equal among populations. For example, consider the scenario where 10 of 35 animals tested positive for ranavirus in one population and 20 of 45 tested positive in another. The contingency table is:

\begin{tabular}{l|l|l|l}
\hline & Population A & Population B & Total \\
\hline Infected & 10 & 20 & 30 \\
\hline Not infected & 25 & 25 & 50 \\
\hline Total & 35 & 45 & 80 \\
\hline
\end{tabular}

The expected infection prevalence, assuming no difference among populations, would be $(10+20) /(35+45)=0.375$. Thus, the number of infections one would expect in each population would be $0.375 \times 35$ animals $=13.125$ in the first population and $0.375 \times 45$ animals $=16.875$ in the second. The $\chi^{2}$-test statistic is the sum of the squared differences between observed and expected values divided by the 
expected value for populations $i=1,2,3, \ldots, n$. This statistic is compared to a critical value from the chi-squared distribution with (row -1$) \times($ columns -1$)$ degrees of freedom for evidence that infection prevalence is different in at least one population. Here there are two rows for infected and uninfected, and two columns for the two populations, so the degrees of freedom $=(2-1) \times(2-1)=1$. If the test is significant and there are $>2$ populations, subsequent pairwise comparisons can be performed following the same methodology, with appropriate correction of experimentwise error rate (e.g., Bonferroni correction). Chi-square tests require that no more than $20 \%$ of expected counts are $<5$, which may not be achieved especially in populations with low infection prevalence. If one margin of the contingency table is fixed (e.g., if the number of samples from sites A and B in our example were set a priori at 35 and 45, respectively), then Barnard's exact test is a powerful alternative to the chi-square test that avoids the problem with low expected counts (Martín Andrés et al. 2004), and can be performed using the "Barnard" package in R. Appendix 1 provides example code in $\mathrm{R}$ for testing for differences in proportions.

Logistic regression is a robust and more flexible framework for comparing the probability of infection (or death) among individuals or populations given environmental or host characteristics. The logistic model predicts the logit-transformed probability of a binary outcome (e.g., infection, mortality) as a linear function of one or more predictor variables:

$$
\operatorname{logit}\left(p_{i}\right)=\ln \left(\frac{p_{i}}{1-p_{i}}\right)=\beta_{0}+\beta_{1} x_{1, i}+\cdots+\beta_{m} x_{m, i},
$$

where $\beta_{0}, \ldots, \beta_{m}$ are the intercept and regression coefficients for predictor variables $x_{1}, \ldots, x_{m}$. The logit transform is the log of the odds ratio, where the odds ratio is calculated by exponentiating both sides of (5).

$$
\exp \left(\operatorname{logit}\left(p_{i}\right)\right)=\left(\frac{p_{i}}{1-p_{i}}\right)=\mathrm{e}^{\left(\beta_{0}+\beta_{1} x_{1, i}+\cdots+\beta_{m} x_{m, i}\right)}
$$

If $x_{1}$ is a categorical predictor (e.g., male vs. female), then $\exp \left(\beta_{1}\right)$ can be interpreted as the increased (or decreased) odds of infection for males relative to females. If $x_{1}$ is instead a continuous variable (e.g., animal length), then $\exp \left(\beta_{1}\right)$ is the increased (or decreased) odds of infection with a one-unit increase in the predictor variable. It is important to be careful when interpreting odds-ratio coefficients relative to the units measured (e.g., mm vs. cm) as well as in the context of the range of values that were measured. For example, a large predicted increase in risk with each centimeter may seem impressive, but if all of the animals measured were within $0.1 \mathrm{~cm}$ of each other, the actual effect size is much less substantial.

Logistic regression can also be used to estimate the risk factors associated with ranavirus occurrence among populations (e.g., Gahl and Calhoun 2008; Greer and Collins 2008). For instance, you may be interested in finding the predicted probability of ranavirus infection or a die-off occurring in particular populations. It is possible to 
use the coefficients of the logistic regression to predict this probability for population $i$ (or analogously, individual $i$ ) as:

$$
p_{i}=\frac{\mathrm{e}^{\beta_{0}+\beta_{1} x_{1, i}+\cdots+\beta_{m} x_{m, i}}}{1+\mathrm{e}^{\beta_{0}+\beta_{1} x_{1, i}+\cdots+\beta_{m} x_{m, i}}}=\frac{1}{1+\mathrm{e}^{-\left(\beta_{0}+\beta_{1} x_{1, i}+\cdots+\beta_{m} x_{m, i}\right)}} .
$$

Suppose we fit a logistic regression model predicting the occurrence of ranavirus in wetlands as a function of distance from the nearest road where the intercept was $\beta_{0}=-0.5$ and the slope parameter for distance was $\beta_{1}=-0.1$. In this case, a pond that was $10 \mathrm{~km}$ from a road would have a predicted probability of ranavirus occurrence as: $1 /(1+\exp [-(-0.5+-0.1 \times 10)])=0.182$, while a population that was $5 \mathrm{~km}$ away would have a predicted probability of $1 /(1+\exp [-(-0.5+-0.1 \times 5)])=0.269$. Most statistical packages will provide predicted probabilities and confidence intervals from a logistic regression model. Appendix 1 provides example code in R for logistic regression.

\subsection{Viral Titers}

The above statistical approaches classify infection as binary; an individual is infected or not. However, infection can be thought of as a continuum from subclinical to clinical infections, where the latter is resulting in disease and possibly mortality (Miller et al. 2015). Quantitative PCR and cell culture-based methods (e.g., plaque assays and $\mathrm{TCID}_{50}$ ) are common techniques to estimate viral titers in tissue (Miller et al. 2015). Inasmuch as viral titers in tissues correlate with the severity of infection, these data provide additional insight into the possible effects of ranavirus on populations. Consider, for instance, measuring ranavirus prevalence and titers through time in a population of a tolerant species (e.g., American bullfrog, Lithobates catesbeianus; Hoverman et al. 2011). One might observe that the prevalence of ranavirus was quite high, but titers were very low. If changing conditions (e.g., rising temperatures) were hypothesized to make this species more susceptible, then one would expect to see viral titers increase with increasing temperature, while prevalence of infection would remain unchanged.

Vital titers are often reported as $\log _{10}$-transformed values of virus concentration per unit of genomic DNA or tissue. Such transformed titers are generally normally distributed, which are suitable for simple linear models (i.e., regression, analysis of variance). For example, the relationship discussed above could be tested with a linear regression of viral titers on temperature.

Because the log of zero is undefined, it is common practice to add one or a number representing the minimum detectable level to all numbers including zero before taking the log. If there are many zeros (i.e., individuals that tested negative) in the dataset, the resulting distribution will not be normal. However, if you are interested in the distribution of titers in infected animals only, it is appropriate to exclude the 
zeros for the uninfected individuals. Alternatively, you can use zero-inflated models. These models account for the probability that an individual is infected using the equivalent of a logistic model, and given that an animal is infected, predicts the number of virions with typically a Poisson or negative binomial distribution. These models can also be applied to other surveillance data, such as the number of infected animals in a population, where there may be zeros because there is no infection in the population or because infected animals were missed during sampling. We direct the readers to Dohoo et al. (2003) and Zuur et al. (2012) for additional guidance.

\subsection{Analysis of Survival Data}

While we are often interested in the probability of infection or death, it is also useful to understand the timing or rate of mortality. In survival analyses, the fate of specific individuals is followed over time at frequent intervals; thus, these designs are probably most appropriate in captive populations (e.g., zoos, laboratory studies), where every individual can be checked regularly. When the fate of all individuals is known over time, survival can be represented as a curve ranging from 100 to $0 \%$ over the duration of the study.

Censoring is when the fate of some individuals during a study is unknown, and must be accounted for in survival analyses. Right censoring occurs when the fate of an individual is not observed after some point in time; the individual is censored after its last observation. Right censoring also occurs when individuals are euthanized during or at the end of a study to collect diagnostic information. If an animal was infected at some unknown time before the start of the study, it is left censored. In field studies, it is common that individuals are added to a study after the first sampling date, which is called staggered entry.

Information on the fate of individuals at risk at each time point (i.e., excluding those that have been censored) is used to estimate time-specific survival, $S(t)$, and analyzed with various statistical packages (e.g., Program MARK, http://www.phidot.org/software/mark/). One of the most common survival estimators is the Kaplan-Meier (K-M) function:

$$
S(t)=\prod_{t_{i}<t} \frac{n_{i}-d_{i}}{n_{i}}
$$

where $S(t)$ is probability of surviving until time $t=t_{i}, n_{i}$ is the number of individuals that survived and were not censored before time $i$, and $d_{i}$ is the number that died at time $t_{i}$ (see Jager et al. 2008 for an overview). The probability of surviving up to time $t$ is the product of the current and previous survival probabilities.

The K-M survival estimates can be compared between two groups of samples using the Mantel-Haenszel test, which is essentially a contingency table approach 
(Sect. 5.2), where expectations and deviations are calculated through time. The contingency table is:

\begin{tabular}{r|c|c|c}
\hline & Group A & Group B & Total \\
\hline Event & $d_{\mathrm{A} i}$ & $d_{\mathrm{B} i}$ & $d_{i}$ \\
\hline No Event & $n_{\mathrm{A} i}-d_{\mathrm{A} i}$ & $n_{\mathrm{B} i}-d_{\mathrm{B} i}$ & $n_{i}-d_{i}$ \\
\hline At Risk & $n_{\mathrm{A} i}$ & $n_{\mathrm{B} i}$ & $n_{i}$ \\
\hline
\end{tabular}

where $i$ refers to the time $t_{i}$ and subscripts A and B are the two groups. The expected number of deaths at time $t_{i}$ in group $\mathrm{A}$, if both groups are identical in terms of their survival functions, is:

$$
\hat{e}_{\mathrm{A} i}=\left(d_{i} \times n_{\mathrm{A} i}\right) / n_{i}
$$

Now, the expected number of deaths can be compared to the actual number of deaths in group A at time $t_{i}$, and repeated over $i=1,2,3, \ldots, m$ sample periods. In the case of comparing two groups, expectations can be calculated for one group, because deviations in group A imply deviations in group B. The test statistic is:

$$
Q=\frac{\left(\sum_{i=1}^{m} d_{\mathrm{A} i}-\sum_{i=1}^{m} \hat{e}_{\mathrm{A} i}\right)^{2}}{\sum_{i=1}^{m} \hat{V}\left(\hat{e}_{\mathrm{A} i}\right)}
$$

where $V$ is the variance of the expected number of deaths. The test statistic is chisquare distributed with one degree of freedom (Dohoo et al. 2003; Hosmer et al. 2008).

While the Mantel-Haenszel test is relatively easy to calculate, it cannot accommodate more than two groups or continuous predictors or covariates. The Cox Proportional Hazard (Cox PH) model is a more general method of testing for differences in survival curves among groups, or among individuals with continuous covariates (e.g., body size). Cox PH estimates a baseline hazard function (Box 1), and tests whether individuals in the groups have a higher or lower hazard than the baseline (Hosmer et al. 2008). Cox PH nonparametrically estimates a baseline hazard function, $h_{0}(t)$, from the data. The hazard for an individual with covariates $x_{1}, x_{2}, \ldots, x_{n}$ is:

$$
h_{0}(t) \mathrm{e}^{\left[\beta_{1} x_{1}+\beta_{2} x_{2}+\cdots+\beta_{n} x_{n}\right]} .
$$

When the linear portion of the model in brackets is equal to zero, the exponential term is one and the hazard is equal to $h_{0}(t)$, the baseline hazard. If the sum of the terms in brackets is $>0$, then the hazard increases by some proportion; if it is $<0$, the hazard is reduced by some proportion. For example, if the coefficient for 
females (relative to males) was $\beta_{\text {Female }}=0.693$, then females would have a hazard that was $\exp (0.693)=2 \times$ greater than that of males. In Cox PH analyses, the focus tends to be on the proportional differences in survival between groups, although it is possible to extract the baseline hazard from most statistical packages.

There are limitations to the Cox PH model. First, it cannot accommodate leftcensored observations. Second, it assumes the proportional difference in hazard between groups (e.g., males vs. females) is constant through time. Thus, if survival curves are plotted, they should not cross or diverge; they should be approximately parallel through time. If meeting either of these assumptions is unreasonable, readers should consult a text on survival analyses (e.g., Dohoo et al. 2003; Hosmer et al. 2008) or statistician for alternative approaches.

One alternative approach to Cox PH is accelerated failure time (AFT) models, sometimes called parametric survival models (Hosmer et al. 2008). There are two key differences between AFT and Cox PH models. First, in AFT models, the functional form (but not rates) of the underlying hazard is specified a priori rather than estimated from the data (Box 1). For instance, a constant hazard would be modeled using an exponential model (Hosmer et al. 2008). Because the form of the hazard is set $a$ priori and only the model parameters are estimated, survival estimates can be predicted beyond the observed time period and may have more statistical power.

\subsection{Mark-Recapture Studies}

Many of the difficulties inherent in estimating epidemiologically relevant parameters in wildlife populations (e.g., individual fates, population size) can be addressed using CMR methods (reviewed in Cooch et al. 2012). This is an active area of research

\section{Box 1}

Hazard function, $h(t)$-instantaneous rate of death at time $t$. The cumulative hazard is written as $H(t)$.

Survival function, $S(t)$ - probability of surviving beyond time $t$.

Probability density function, $f(t)$-the expected distribution of times to death.

These functions are related to each other:

$$
\begin{gathered}
h(t)=\frac{f(t)}{S(t)}=-\frac{\partial \ln S(t)}{\partial t} \\
f(t)=S(t) h(t) \\
S(t)=\exp \left[-\int_{0}^{t} h(t)\right]=\exp [-H(t)] .
\end{gathered}
$$


and one with a large literature (e.g., Amstrup et al. 2005; Thomson et al. 2009). Thus, we will simply provide an overview of approaches that may prove useful to understanding ranavirus epidemiology and direct the reader to the literature above.

Closed population models are particularly useful for estimating population size (or density) and prevalence of infection. These models assume that the initial and subsequent recapture sessions occur close enough in time that one can assume there has been no birth, death, immigration, or emigration. In the simple case where there are two capture occasions, the population size, $\hat{N}$, is estimated by the actual count of individuals, $C$, adjusted for the detection probability, $\hat{p}$ (i.e., the LincolnPeterson estimator):

$$
\hat{N}=C / \hat{p}
$$

The detection probability is estimated as the fraction of initially marked individuals that are recaptured. This model can be extended to account for multiple capture sessions as well as differences between groups (e.g., males vs. females) or states (e.g., infected vs. uninfected). Importantly, the detection probability can be modeled separately for different groups or states, which allows you to account for differences in detection probabilities between ranavirus-infected and -uninfected or symptomatic and asymptomatic animals (see Sect. 2.1).

Open CMR models do not assume that the population is closed to demographic changes and are generally better suited for repeated monitoring and estimating demographic parameters, particularly apparent survival, $S$. Parameters in open CMR models can be modeled separately between groups (e.g., infected and uninfected) or as a function of covariates (e.g., age, size), which provides a means of estimating the impact of disease on individuals in natural settings. One could, for instance, determine whether apparent survival differs between ranavirus-infected and -uninfected fish, and whether these differences are constant between adults and juveniles. In a similar framework, it may be possible to estimate the population growth rate as a function of the occurrence or prevalence of disease (Cooch et al. 2012).

Multi-state models are an extension of CMR models that allow individuals to transition between different states (e.g., uninfected and infected). This powerful modeling approach provides a means of estimating the rate or probability of transitioning from uninfected to infected states (i.e., incidence) and vice versa. These models assume that survival and transitions between states are temporally separated (e.g., individuals first survive then become infected). Additionally, only one transition (e.g., uninfected to infected) can occur between encounter events. Thus, careful design of a CMR study is essential. These and related models can be extended to account for misclassification of states (e.g., infection status is not measured perfectly) or partial observability (e.g., the individual is observed but its infection status is not determined). Considering the complexity of working with CMR models, we recommend consulting a statistician during study design and analysis. 


\section{Use of Dynamic Models}

Dynamic models can be very useful in studying host-pathogen interactions. Within-host models can elucidate physiological mechanisms that lead to host infection and disease (e.g., Mideo et al. 2008, 2011; Woodhams et al. 2008). In comparison, between-host models focus on the fate of individuals and populations when a pathogen is introduced or circulating (Hastings 1997). In this section, we will focus on the latter because of their usefulness in predicting the effects of pathogens on populations. To date, few dynamic models have been formulated for ranaviruses (e.g., Duffus 2009). Thus, several of our examples will come from the wildlife disease literature and modeling efforts with the emerging pathogen Batrachochytrium dendrobaditis $(\mathrm{Bd})$.

\subsection{SI/SIR Models: Transmission}

Susceptible-infected-recovered (SIR) models examine transmission dynamics using a series of ordinary differential equations that model and predict one of three outcomes: pathogen extinction, host extinction, or pathogen-host persistence (Allen 2006). In many simple cases, the total population of hosts is divided into three subpopulations: individuals susceptible to infection $(S)$, infected individuals $(I)$, and individuals that have recovered $(R)$ from infection and cannot be re-infected or at least have temporary immunity. $R$ can also be the individuals removed from the population. A simpler version of the model is where individuals cannot become immune, the susceptible-infected (SI) model (Allen 2006). In this version, if individuals clear the infection, they become susceptible again. Here, we describe the basic SIR model.

In the simplest continuous time SIR model, the total population size $(N)$ can be assumed constant

$$
N=S+I+R
$$

where $S, I$, and $R$ represent the number of individuals in each respective subpopulation (Hastings 1997). The rate of change of each subpopulation at time $t$ can be modeled as

$$
\begin{gathered}
\mathrm{d} S / \mathrm{d} t=-\beta S I \\
\mathrm{~d} I / \mathrm{d} t=\beta S I-\gamma I \\
\mathrm{~d} R / \mathrm{d} t=\gamma I
\end{gathered}
$$

where $\beta$ is the rate at which hosts contact and transmit the infection to each other and $\gamma$ is the host recovery rate (or removal rate). Here, transmission is assumed to 
be density-dependent, as transmission is represented as $\beta S I$. Some evidence exists that transmission of ranavirus may be density-independent (Harp and Petranka 2006), and can be modeled as $\beta I / N$. McCallum et al. (2001) provide other forms of transmission functions, including density-independent transmission and nonlinear functions of density. Because demography (birth, death, immigration, or emigration) is not included in this model, the only equilibrium occurs when all individuals are in the susceptible class (with $I=0$ ). For an epidemic to occur, the number of infected individuals must increase $\mathrm{d} I / \mathrm{d} t>0$. The reproductive number of a disease $\left(R_{0}\right)$ is the number of secondary cases that one infected individual would produce on average in a susceptible population, and is equal to

$$
R_{0}=\beta S / \gamma
$$

If $R_{0}>1$, number of infections are increasing in a population, and is representative of an epidemic. However, due to the density-dependent nature of this model, there is a minimum population size for an epidemic to occur (the threshold population size is $\left.N_{\mathrm{T}}=\gamma / \beta\right)$, and the epidemic ends before all susceptible individuals become infected (Hastings 1997). When modeling epidemics, the time scale is assumed short enough to ignore births and other forms of mortality in the host population. This assumption can be relaxed in more complex models by adding births to the susceptible population and natural mortality to each subset of the population.

For ranavirus and most natural populations, the basic SIR model is likely too simplistic. Duffus (2009) used a discrete-time SI model to show that ranavirus could be maintained in a population of common frogs (Rana temporaria) in the UK with only transmission between adults. Her model included natural and disease induced mortality and recruitment from earlier life stages. The transmission rate was determined by the contact rate between adults and the likelihood of being infected given contact. Duffus (2009) also demonstrated that transmission between adults could maintain two syndromes of ranavirus (the ulcerative and hemorrhagic forms) in a single population. These models showed the conditions that could result in persistence of ranavirus in populations of common frogs, and which parameter estimates need additional data to better understand the system and predict outcomes in particular populations (Duffus 2009). Another model is in development for wood frogs (Lithobates sylvaticus) that investigates stage-specific susceptibility and waterborne transmission to recreate die-off patterns observed in natural populations (JLB, unpublished data).

Other model expansions could be particularly useful for predicting ranavirus dynamics in natural populations. For example, most ranavirus host species exist in communities where they are likely to interact with other susceptible species, possibly from different ectothermic vertebrate classes (Gray et al. 2009). Brenes et al. (2014a) demonstrated that interclass transmission of ranavirus through water was possible. He also showed that ranaviral disease outcomes depended on species composition in the amphibian community and which species was initially infected with ranavirus (Brenes 2013). These studies could serve as a starting point for determining transmission probabilities in aquatic communities with multiple species. 
In other disease systems, the addition of multiple species to transmission models had an effect on the focal host population, but depended on the host's competency as a reservoir and its dominance within the community (Keesing et al. 2006). The addition of multiple host species can make the analysis of SIR models challenging. To date, most models have included only two species and the pathogen (Keesing et al. 2006), which may be unrealistic for some ranavirus-host systems. Dobson (2004) dealt with the large number of parameters in multi-species models by scaling the parameters as allometric functions of host body size, although it is unclear such a relationship exists with transmission of ranavirus. Lélu et al. (2013) provide an example of a model including trophic transfer of a parasite (Toxoplasma gondii) from rats to cats and vertical transmission in cats. Similar complex interactions certainly occur among ranavirus hosts species, such as predation or necrophagy, and mechanical transmission by mosquitoes has been hypothesized (Allender et al. 2006; Johnson et al. 2007; Kimble et al. 2014). Despite the large number of possible interactions in a ranavirus-host system, several interactions are likely unimportant to its epidemiology. One strategy would be to create several competing models and fit them to data on dynamics in natural populations or in mesocosm studies to identify the most important mechanisms for transmission.

For researchers interested in using SIR models to examine ranavirus, we recommend Otto and Day's (2007) book A Biologist's Guide to Mathematical Modeling in Ecology and Evolution, which reviews the mathematics and describes the process necessary for constructing and analyzing models primarily with ordinary differential equations. An understanding of computer programming and use of software (e.g., Matlab, Maple, Mathematica, R) will be necessary to construct models and perform simulations for most analyses. Appendix 2 provides example code in Matlab for a simple SIR model.

\subsection{Individual-Based Models/Pattern-Oriented Modeling}

Individuals-based models (IBMs), sometimes called agent-based models (ABMs), are also very useful for examining disease dynamics. IBMs are simulation-based, and during each time step, a set of rules or probabilistic events occurs involving each individual. IBMs are often easier for biologists to construct than SIR models, because they do not require solving differential equations. However, IBMs can be complex and require computer programming skills. These models often operate on a set schedule of events that are implemented using sequential equations, a series of for-loops, and if-then statements that determine an individual's actions or fate. For disease IBMs, each individual's disease state is recorded and their risk of infection can depend on their interaction with other individuals or the environment. There are also other types of IBMs that use differential equations. For example, Briggs et al. (2010) developed an IBM with differential equations that explicitly incorporated individual $\mathrm{Bd}$ load and further examined how a pathogen reservoir and a long-lived tadpole stage affected whether the frog population could persist with $\mathrm{Bd}$ 
or experience local extinction. Similar models could be developed for ranavirus that include viral load and shedding to better understand how the virus might interact with the host and factors that initiate die-offs. One attractive aspect of IBMs is that they can explicitly incorporate animal behavior. For ranavirus, researchers might be interested in how different behaviors, such as schooling or necrophagy, affect host populations and persistence with the pathogen.

A useful technique for creating IBMs and determining plausible interactions is called pattern-oriented modeling (POM). In POM, data are used to determine several salient patterns seen in a natural system of interest that form the basis of model evaluation. Multiple possible forms of an IBM are created, representing different hypotheses about host-pathogen interactions. The different IBMs are evaluated based on their ability to recreate the salient patterns (Grimm et al. 2005; Grimm and Railsback 2012). When a model is able to match multiple patterns, it is more likely to be structurally realistic (Wiegand et al. 2003), and capable of producing testable predictions. In using POM, researchers can also contrast different hypotheses, determine a useful model structure, and reduce parameter uncertainty.

For researchers interested in developing IBMs, we recommend two books: Grimm and Railsback's (2005) Individual Based Modeling and Ecology and Railsback and Grimm's (2011) Agent-Based and Individual-Based Modeling: A Practical Introduction. Both titles describe a "best model practice" called objectoriented design and description (ODD), which is a standard format to describe various aspects of an IBM. The latter title goes through the process of building IBMs with examples and code for a relatively user-friendly and free program called NetLogo (http://ccl.northwestern.edu/netlogo/index.shtml). NetLogo includes a library of preconstructed models, including AIDS, Disease Solo, and Virus, which could form the basis for the development of models for ranavirus. Further, NetLogo's website includes a Modeling Commons, where NetLogo users can share their models to help others in their own model development. Other software, such as Matlab and R, can also be used to develop and analyze IBMs.

\subsection{Population Matrix Models}

Population matrix models examine changes in population size and age structure over time. These models include parameters for the transition probability between each age class. To incorporate disease, the survival following exposure to ranavirus can be incorporated for each age class. Earl and Gray (2014) developed a stagestructured matrix model to predict the effects of ranavirus exposure during the egg, hatchling, larval, and metamorph stages on a closed population of wood frogs. This study combined information from a wood frog population model (Harper et al. 2008) with experimental challenge data (Haislip et al. 2011) to predict population outcomes. Appendix 2 provides example code in Matlab for a matrix model following Earl and Gray (2014).

Population matrix models can also be combined with transmission models to more realistically model both dynamics simultaneously. For example, Briggs et al. (2005) 
merged a population model of yellow-legged frogs (Rana muscosa) and a SIR model of the infection dynamics of Bd based on the current knowledge of transmission and mortality rates. This model combined discrete-time between-year population dynamics with a continuous time transmission dynamics within each year. By running the model with different parameter values, Briggs et al. (2005) were able to determine which conditions resulted in extinction of the frog population, nonpersistence of the pathogen, and persistence of the frog population and the pathogen.

Population models can also be scaled up to take into account metapopulation processes. A metapopulation is a set of spatially structured local populations that periodically interact via dispersal (Marsh and Trenham 2001; Smith and Green 2005). Several ranavirus host species are likely structured as metapopulations. Metapopulation models incorporate parameters for dispersal probability between local populations as well as demographic parameters in each local population. Metapopulation models are useful to understand the spatial spread of pathogens among populations and examine the effectiveness of disease intervention strategies (Hess 1996). In amphibians, the occurrence of ranavirus outbreaks has been attributed partly to subclinically infected juveniles or adults returning to breeding sites, shedding the virus, and infecting larvae (Brunner et al. 2004). For individuals interested in population matrix models, we recommend Caswell's (2000) Matrix Population Models: Construction, Analysis, and Interpretation. Hanski's (1999) Metapopulation Ecology will be useful for those interested in investigating ranavirus effects on metapopulation dynamics.

\subsection{Modeling Disease Intervention Strategies}

One goal of modeling host-pathogen dynamics is to identify intervention strategies that thwart disease outbreaks. Currently, there are few proposed control options for ranavirus, but vaccine development is possible in the future (Miller et al. 2011). Other options include quarantining individuals or populations, culling, and creating captive populations for reintroduction if disease is likely to cause extremely high mortality to populations of conservation concern. Models also can be used to identify vulnerable points in the host-pathogen cycle that can be interrupted with intervention strategies. For example, if outbreaks are a consequence of density, emergent vegetation in wetlands can reduce the probability of transmission among amphibian larvae (Greer and Collins 2008). If stressors in the aquatic environment (e.g., high nitrogen levels) are resulting in reoccurring outbreaks, strategies that improve water quality can be used. A thorough understanding of the factors responsible for outbreaks and the ranavirus-host system is essential to identifying plausible intervention strategies. In some cases, possible intervention strategies might be infeasible to implement, excessively costly, or undesirable in natural populations. However, if strategies are feasible, models can be used to determine when and how often the strategy should be employed for the best results. SIR models and their variants can be used to explore vaccination strategies (Hethcote 2000) and other control techniques such as culling 
(Lloyd-Smith et al. 2005). Cost of disease control can be incorporated into models to determine the best strategies given financial constraints (Fenichel et al. 2010). Woodhams et al. (2011) discussed possible intervention strategies for Bd and presented model results of their efficacy on individuals with and without an adaptive immunity. They also went on to show that reducing the host population size (i.e., decreasing transmission probability) could prevent extinction. For researchers interested in implementing optimal control models, we recommend Lenhart and Workman's (2007) Optimal Control Applied to Biological Models, which focuses on control of continuous ordinary differential equation models and includes sample code for the computer program Matlab. Optimal control can also be applied to IBMs, but effective techniques are still being developed (Federico et al. 2013).

\subsection{Model Parameterization and "Evaludation"}

There are a number of ways to parameterize models and integrate them with data. Frequently, modelers choose parameter values by searching the literature, but often not all parameter values are available. Another method is to construct a model and fit the output to an existing data sequence. In the case of ranavirus modeling, predictions could be fit to surveillance data that include abundances of infected and uninfected individuals, or the magnitude and timing of a die-off. After the model is fit to the data, the parameter values that give the best fit or that match multiple patterns (as in POM) are then used. If some parameters are known and researchers have a good idea of the possible range of other parameters, these ranges of values can be explored to determine how they change the model output. Assessing the effects of changes in parameter values is called sensitivity analysis (Cariboni et al. 2007). If the model is especially sensitive to a certain parameter, it suggests that better parameter estimation would be a valuable research direction (Biek et al. 2002; Cariboni et al. 2007), especially if the parameter estimate is not based on robust data (e.g., low sample sizes). Cariboni et al. (2007) suggest best practices for sensitivity analysis. An excellent review of parameter estimation for disease modeling of natural populations can be found in Cooch et al. (2012).

The aim of model evaluation is to determine if models typify natural systems well enough to represent the intended dynamics. This often involves determining whether or not they can be used to make accurate predictions. Frequently, the terms model evaluation, model validation, and model testing are used interchangeably. Because models are built on assumptions and simplifications, they are never truly "valid" or "correct." Augusiak et al. (2014) have suggested the term "evaludation" to represent the process of assessing the model's quality and reliability, and included six elements for proper "evaludation" of a model:

- Assessing the quality of the data used to build the model

- Evaluating the simplifying assumptions structuring the model

- Verifying that the model is correctly implemented 
- Verifying that the output matches the data used to design the model

- Exploring model sensitivity to changes in parameter values, and

- Assessing whether the model can fit an independent data set not used in original model formulation.

It is recommended that model formation and "evaludation" follow a documentation procedure called TRACE (TRAnsparent and Comprehensive Ecological documentation) that is designed to ensure reliability of models and link the science to application (Grimm et al. 2014).

\section{Risk Analysis for Introduction of Ranavirus into an Uninfected Area}

Import risk analysis (IRA) is a procedure that can be used to determine the threat of a pathogen entering a system. The consequences of pathogen introduction can be monitored directly (Sect. 2) or simulated using models (Sect. 6). The guidelines for IRA have been primarily developed from a trade perspective between two countries or regions to assess the disease risk associated with the import of live terrestrial production animals. However, the same principles can be applied to assess the risk of ranavirus introduction in wild or captive populations. In general, IRAs focus on possible infection of one species or several species within the same taxonomic class. As discussed in Duffus et al. (2015), ranaviruses are multi-species pathogens that have the capability of infecting three vertebrate classes, which makes IRA for ranaviruses complex. IRAs can be used to establish or revise trade or translocation guidelines for wildlife that could be subclinically infected with a pathogen (Smith et al. 2009). The World Organization for Animal Health (OIE) lists ranaviruses that infect amphibians as notifiable pathogens, meaning that a subsample of amphibians that are involved in international trade should be verified ranavirus negative prior to shipment (Schloegel et al. 2010). Currently, these regulations are not being enforced in most countries (Kolby et al. 2014). The procedures we outline below are based on principles and recommendations of the OIE (Vose 2000; OIE 2014), with examples of how they can be applied to parts of an IRA for the introduction of a ranavirus into an uninfected area.

\subsection{Defining the Hazard}

The first step in an IRA is defining an area of interest. The area could be a population of interest, such as one that contains an uncommon species that is susceptible to ranavirus, or it could be a geographic region or country (Rödder et al. 2009; OIE 2014). Generally, areas are defined based on artificial or natural barriers to animal movement or pathogen translocation (OIE 2014). For example, ranavirus virions can flow downstream in tributaries, and associated floodplains are often corridors 
for animal movement; thus, areas should be defined by watershed for lotic systems. In lentic systems, depressional wetlands or lakes containing possible ranavirus hosts could be defined as the area of interest if it is hydrologically closed and surrounded by a terrestrial landscape. In zoological settings, the area of interest typically is the captive facility (OIE 2014).

The next step is determining the presence of ranavirus in the area of interest. Section 2 discussed surveillance studies, and additional guidelines are provided by OIE (2014). Minimum sample size to detect ranavirus depends on several factors (Sect. 2, Table 1). Additionally, infrequent sampling can result in lack of detection. Todd-Thompson (2010) showed that ranavirus in Gourley Pond of the Great Smoky Mountains National Park appeared nonexistent except for a 3-week period in late spring when an outbreak occurred resulting in widespread mortality across multiple species. Thus, sampling sites every 2 weeks when hosts are present with a large sample size $(n>30)$ should result in a high detection probability. If resources are limiting, sampling at least four periods per year while hosts are present may be sufficient. Using this sampling frequency, Hoverman et al. (2012) detected ranavirus at 33 of 40 sites. Given that ranavirus could have been present at all sites in this study, a ballpark estimate of detection probability was $82.5-100 \%$ with their sampling frequency. Sampling should be performed over several years to verify that a site is ranavirus negative. For large areas of interest, multiple sites spaced no less than the average dispersal distance of hosts should be sampled, which for amphibians is about $1 \mathrm{~km}$ (Wells 2007). Thus, distinct populations should be sampled without leaving large gaps between them. If ranavirus is detected, there is no reason to conduct an IRA, unless there is concern of a foreign strain of ranavirus being introduced.

Although the primary interest in the introduction of ranavirus to an area typically is for a certain species of conern, it is important that all ranavirus hosts are considered in an IRA. As discussed in Brunner et al. (2015), some hosts function as reservoirs for the virus and maintain subclinical infections resulting in low population prevalence, while other species serve as amplification hosts and initiate outbreaks. If funds are limited, a viable strategy would be to test amplification hosts, because these species tend to have lower resistance to ranavirus, and detection probabilities are therefore greater. Duffus et al. (2015) provide a list of known ranavirus hosts, and several challenge studies (e.g., Hoverman et al. 2011; Brenes et al. 2014b) can provide insight into relative difference in susceptibility between species.

\subsection{Risk Assessment}

Risk assessment involves three primary steps: identifying routes of introduction, identifying the consequence of introduction, and estimating risk. It is often useful to develop flow diagrams that illustrate each step of assessment (Figs. 1 and 2). To describe this process, below we provide an example of assessing risk to wild amphibians via import of aquacultured fish that are infected with ranavirus. 


\begin{tabular}{|c|c|c|c|}
\hline Stage & Control point & Event & Assumption \\
\hline \multirow[t]{4}{*}{ Import } & Origin of import & $\begin{array}{l}\text { Import into study } \\
\text { zone }\end{array}$ & $\begin{array}{l}\text { Imported fish are } \\
\text { infected with } \\
\text { ranavirus }\end{array}$ \\
\hline & Border inspection & $\begin{array}{l}\text { Fish are released to } \\
\text { importer }\end{array}$ & $\begin{array}{l}\text { Ranavirus is not } \\
\text { detected in } \\
\text { consignment }\end{array}$ \\
\hline & Importer / retailer & $\begin{array}{l}\text { Fish are sold to fish } \\
\text { farm }\end{array}$ & $\begin{array}{l}\text { Ranavirus is not } \\
\text { detected in } \\
\text { consignment }\end{array}$ \\
\hline & Fish farm & (1) & $\begin{array}{l}\text { Ranavirus is not } \\
\text { detected in } \\
\text { consignment and not } \\
\text { contained within } \\
\text { farm. }\end{array}$ \\
\hline \multirow[t]{2}{*}{ Release } & & $\begin{array}{l}\text { Release of virus to the } \\
\text { environment }\end{array}$ & \\
\hline & Environment & 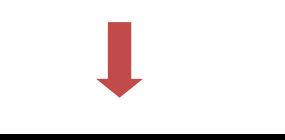 & $\begin{array}{l}\text { Susceptible } \\
\text { amphibian species } \\
\text { inhabit this } \\
\text { environment }\end{array}$ \\
\hline Exposure & Exposure & Exposure & $\begin{array}{l}\text { Susceptible animals } \\
\text { get infected }\end{array}$ \\
\hline
\end{tabular}

Fig. 1 Flow diagram for possible routes of transmission of ranavirus into a naïve susceptible population of amphibians in the wild

\subsubsection{Routes of Introduction}

Routes of introduction could include dispersal paths of hosts or translocation of the virus on fomites attached to non-hosts (i.e., birds and mammals, Gray et al. 2009). Humans can play a large role in the possible introduction of ranavirus by moving between contaminated and uncontaminated sites. The environmental persistence of ranavirus in unsterile water and soil is probably at least one week (Nazir et al. 2012). Thus, recreationists that move among watersheds without decontaminating footwear or gear could be a major source of ranavirus introduction (Gray et al. 2009). Fish hatcheries are known sites of ranavirus outbreaks (Waltzek et al. 2014); thus, the release of clinically or subclinically infected fish or their effluent from the hatchery could be another major source of ranavirus introduction. For a particular area of interest, it is important to identify the most likely routes of introduction. It can be useful 
to divide routes of introduction into three stages: import, release, and exposure. In the case of imported aquacultured fish, the following steps define the import stage:

- Imported fish from an infected zone are infected with ranavirus

- The infection passes undetected through border control

- The infected fish are released to the retailer

- The infected fish are sold to an aquaculture facility in the study zone.

Assuming that fish are contained in aquaculture ponds, ranavirus could be released into adjacent aquatic environments via several pathways:

- Virus contaminated effluent is released

- Infected fish escape

- Avian or mammalian predators could transport live or dead fish

- Ranavirus hosts, such as amphibians or reptiles, could enter the pond, become infected, and disperse

- Mechanical vectors, such as pets or humans, could transport the virus on fomites.

Finally, exposure to the virus could occur via several direct and indirect routes (Gray et al. 2009). Host species could be exposed to the virus in water, which is an efficient transmission medium, or the virus could be transmitted by direct contact or consumption of infected hosts (Miller et al. 2011). There is some evidence that ranavirus transmission can be density independent, which can increase extinction probabilities (Brunner et al. 2015).

\subsubsection{Consequence Assessment}

The outcome of ranavirus infection in a species can be described qualitatively or quantitatively in terms of direct or indirect consequences. Direct consequences are the effect that ranavirus has on the species of interest, which typically includes estimating the likelihood of population declines and extinction (Sect. 6). Highly susceptible species that are rare have the greatest probability of extinction (Earl and Gray 2014), especially if these species co-occur with other ranavirus hosts. Indirect consequences are costs associated with pathogen surveillance (i.e., field and diagnostic expenses) and possible repatriation of populations following extinction.

\subsubsection{Risk Estimation}

The assumption is that the virus will travel along the routes that were identified from an infected animal to a susceptible animal. In cases where it is determined that the consequence of ranavirus introduction is unacceptable, a series of critical control points (CCPs) should be established along the routes of introduction identified above, where the virus could be intercepted and the transmission terminated. The probability of the infection passing unnoticed through a CCP is estimated for each $\mathrm{CCP}$ by addressing several questions. This process can be summarized in a scenario 


\begin{tabular}{|c|c|c|c|c|}
\hline \multirow[t]{2}{*}{ CCP 1} & \multicolumn{4}{|c|}{ Is there any inspection of the fish at the border? } \\
\hline & \multicolumn{4}{|c|}{ of detection is negligible } \\
\hline \multirow[t]{2}{*}{ CCP 2} & \multicolumn{4}{|c|}{ Will the fish show clinical signs? } \\
\hline & Yes & No & $\Rightarrow$ Likelihood of & tion is negligible \\
\hline \multirow[t]{2}{*}{ CCP 3} & \\
\hline & \multicolumn{4}{|c|}{$\begin{array}{l}\text { Will inspector recognize the clinical signs? } \\
\qquad \text { No }\end{array}$} \\
\hline \multirow[t]{3}{*}{ CCP 4} & \multicolumn{2}{|c|}{$\begin{array}{l}\text { Will samples be analysed for viral } \\
\text { presence? }\end{array}$} & \multicolumn{2}{|c|}{$\begin{array}{l}\text { Will samples be analysed for viral } \\
\text { presence? }\end{array}$} \\
\hline & Yes & No & Yes & No \\
\hline & 1 & $\begin{array}{l}\text { Likelihood of } \\
\text { detection is } \\
\text { negligible }\end{array}$ & 1 & $\begin{array}{l}\text { Likelihood of } \\
\text { detection is } \\
\text { negligible }\end{array}$ \\
\hline \multirow[t]{3}{*}{ CCP 5} & \multicolumn{2}{|c|}{ Will techniques used detect the virus? } & \multicolumn{2}{|c|}{ Will techniques used detect the virus? } \\
\hline & Yes & No & Yes & No \\
\hline & $\begin{array}{l}\text { Likelihood of } \\
\text { detection (P1) }\end{array}$ & $\begin{array}{l}\text { Likelihood of } \\
\text { detection is } \\
\text { negligible }\end{array}$ & $\begin{array}{l}\text { Likelihood of } \\
\text { detection (P2) }\end{array}$ & $\begin{array}{l}\text { Likelihood of } \\
\text { detection is } \\
\text { negligible }\end{array}$ \\
\hline
\end{tabular}

Fig. 2 Scenario tree for detection of ranavirus in a consignment of infected fish at the border inspection. Critical control points (CCP) 1-5 are opportunities identified where the virus could be detected and future transmission terminated. P1 is the product of the "Yes" answer probabilities in the left branch of the tree. P2 is the product of the two "yes" answer probabilities in the right branch of the scenario tree. The probability of ranavirus not being detected at the border is $1-(\mathrm{P} 1+\mathrm{P} 2)$

tree, where each CCP has a "yes" and a "no" branch, and a likelihood of detection is assigned (Fig. 2). In Fig. 2, CCP 1 and 4 are predetermined for each border control post, while CCP 3 will depend on the training and experience of the inspectors. CCP 2 can be affected by viral load, water temperature, and animal health. Detecting a pathogen in a laboratory test in CCP 5 is a function of two processes: sample size (Sect. 2) and performance of molecular tests (i.e., the sensitivity and specificity of PCR, Miller et al. 2015). The sensitivity and specificity of PCR for ranavirus is an ongoing research direction (Miller et al. 2015), and can be affected by sample type (i.e., lethal vs. nonlethal collection, Gray et al. 2012). In general, it is believed that liver and kidney tissue provide the most reliable estimate of detection followed by tail, toe clips, and blood (Miller et al. 2015). Assuming perfect sensitivity and specificity of PCR, the probability of detecting ranavirus is approximately $95 \%$ 
using the required sample sizes in Table 1. Risk of not detecting ranavirus in an imported consignment is calculated as: 1 -the product of the detection probabilities at all CCPs (Fig. 2).

\subsection{Risk Management and Communication}

To manage the risk of ranavirus introduction, it is useful to perform a riskconsequence assessment. If risk is low but the consequence to the target species is high, risk management priority would be high. If, however, the risk of introducing ranavirus is high but the consequences are low, risk management priority would be low. If the IRA indicates that the consequences are high, then the recommendations to management would focus on the CCPs and how to increase the likelihood of detecting and eliminating an infected consignment in a cost effective manner.

Effective communication is required among stakeholders, both when collecting information to feed into the IRA and in terms of informing end users of the findings, management options, and their implementation. Risk communication is often centered at government level, but individual organizations such as fish farmers or herpetological societies can investigate and implement their own quarantine and surveillance guidelines with qualified diagnostic support. Cooperation and awareness at all levels will greatly reduce the risk of introducing ranavirus into an uninfected area.

Many of the facts needed to carry out a comprehensive IRA may already be available in the published scientific literature and should be used to substantiate the recommendation for a risk analysis. It is important to consider the applicability and quality of the published literature before it is used in risk analyses. Published data might be from a different species, time of year, or continent. If published data do not exist for your species or region, a pilot study can be performed to generate data. Alternatively, obtaining expert opinion following the Delphi method can be an approach to secure preliminary estimates for use in the risk analysis (Helmer 1967; Vose 2000). We recommend that all organizations that are interested in performing an IRA consult experts that study ranaviruses. The GRC is a collection of scientists, veterinarians and practitioners that can provide guidance with setting up IRAs. Each continent has a regional GRC representative that can assist or make necessary connections with experts in your region.

Acknowledgments We graciously thank Jason Rohr (University of South Florida) and Cheryl Briggs (University of California-Santa Barbara) for reviewing earlier drafts of our chapter and providing helpful comments. J.E. Earl's contribution was conducted while a Postdoctoral Fellow at the National Institute for Mathematical and Biological Synthesis, an Institute sponsored by the National Science Foundation, the US Department of Homeland Security, and the US Department of Agriculture through NSF Award \#EF-0832858, with additional support from The University of Tennessee, Knoxville.

Open Access publication was made possible through grants provided by the University of Tennessee (Institute of Agriculture, Office of Research and Engagement, and Department of 
Forestry, Wildlife and Fisheries), Washington State University Libraries, Gordon State College (Office of Academic Affairs), the Association of Reptilian and Amphibian Veterinarians, and the Amphibian and Reptile Conservancy.

Open Access This chapter is distributed under the terms of the Creative Commons Attribution Noncommercial License, which permits any noncommercial use, distribution, and reproduction in any medium, provided the original author(s) and source are credited.

\section{Appendix 1}

The links below are for a guide to using the statistical program $\mathrm{R}$ to estimate confidence intervals, perform chi-square analyses and logistic regression, and plot the appropriate graphs.

http://fwf.ag.utk.edu/mgray/RanavirusBook/Chap8/SampleCode_8.5.html http://fwf.ag.utk.edu/mgray/RanavirusBook/Chap8/SampleCode_8.5.R http://fwf.ag.utk.edu/mgray/RanavirusBook/Chap8/Data.csv

\section{Appendix 2}

The links below are for downloading MatLab programs for doing SIR and stagestructured model simulations.

SIR model:

http://fwf.ag.utk.edu/mgray/RanavirusBook/Chap8/Example_SIR_Model.m http://fwf.ag.utk.edu/mgray/RanavirusBook/Chap8/Example_SIR_Model.txt http://fwf.ag.utk.edu/mgray/RanavirusBook/Chap8/SIR.m http://fwf.ag.utk.edu/mgray/RanavirusBook/Chap8/SIR.txt

Population model:

http://fwf.ag.utk.edu/mgray/RanavirusBook/Chap8/PopulationModelDetails.pdf http://fwf.ag.utk.edu/mgray/RanavirusBook/Chap8/PopulationModelCode.txt http://fwf.ag.utk.edu/mgray/RanavirusBook/Chap8/PopulationExampleModel.m

\section{References}

Allen LJS (2006) An introduction to mathematical biology. Pearson, New York

Allender MC, Fry MM, Irizarry AR et al (2006) Intracytoplasmic inclusions in circulating leukocytes from an eastern box turtle (Terrapene carolina carolina) with iridoviral infection. J Wildl Dis 42:677-684

Amos KH (1985) Procedures for the detection and identification of certain fish pathogens, 3rd edn. American Fisheries Society, Corvallis

Amstrup SC, Mcdonald TL, Manly BFJ (2005) Handbook of capture-recapture analysis. Princeton University Press, Princeton 
Augusiak J, Van Den Brink PJ, Grimm V (2014) Merging validation and evaluation of ecological models to "evaludation": a review of terminology and a practical approach. Ecol Model 280: $117-128$

Biek R, Funk WC, Maxwell BA et al (2002) What is missing in amphibian decline research: insights from ecological sensitivity analysis. Conserv Biol 16:728-734

Brenes R (2013) Mechanisms contributing to the emergence of ranavirus in ectothermic vertebrate communities. Ph.D. Dissertation, University of Tennessee

Brenes R, Gray MJ, Waltzek TB et al (2014a) Transmission of ranavirus between ectothermic vertebrate hosts. PLoS One 9:e92476

Brenes R, Miller DL, Waltzek TB et al (2014b) Susceptibility of fish and turtles to three ranaviruses isolated from different ectothermic vertebrate classes. J Aquat Anim Health 26(2): $118-126$

Briggs CJ, Vredenburg VT, Knapp RA et al (2005) Investigating the population-level effects of chytridiomycosis: an emerging infectious disease of amphibians. Ecology 86:3149-3159

Briggs CJ, Knapp RA, Vredenburg VT (2010) Enzootic and epizootic dynamics of the chytrid fungal pathogen of amphibians. Proc Natl Acad Sci U S A 107:9695-9700

Brown LD, Cal TT, Dasgupta A (2001) Interval estimation for a binomial proportion. Stat Sci 16:101-117

Brunner JL, Schock DM, Davidson EW et al (2004) Intraspecific reservoirs: complex life history and the persistence of a lethal ranavirus. Ecology 85:560-566

Brunner JL, Schock DM, Collins JP (2007) Transmission dynamics of the amphibian ranavirus Ambystoma tigrinum virus. Dis Aquat Organ 77:87-95

Brunner JL, Storfer A, Gray MJ, Hoverman JT (2015) Ranavirus ecology and evolution: from epidemiology to extinction. In: Gray MJ, Chinchar VG (eds) Ranaviruses: lethal pathogens of ectothermic vertebrates. Springer, New York

Cariboni J, Gatelli D, Liska R et al (2007) The role of sensitivity analysis in ecological modelling. Ecol Model 203:167-182

Caswell H (2000) Matrix population models: construction, analysis, and interpretation, 2nd edn. Sinauer, Sunderland

Cooch EG, Conn PB, Ellner SP et al (2012) Disease dynamics in wild populations: modeling and estimation: a review. J Ornithol 152(2):485-509

Dobson A (2004) Population dynamics of pathogens with multiple host species. Am Nat 164:S64-S78

Dohoo I, Martin W, Stryhn H (2003) Veterinary epidemiologic research. AVC, Charlottetown

Duffus ALJ (2009) Ranavirus ecology in common frogs (Rana temporaria) from the United Kingdom: transmission dynamics, alternate hosts, and host-strain interactions. Ph.D., University of London

Duffus ALJ, Waltzek TB, Stöhr AC, Allender MC, Gotesman M, Whittington RJ, Hick P, Hines MK, Marschang RE (2015) Distribution and host range of ranaviruses. In: Gray MJ, Chinchar VG (eds) Ranaviruses: lethal pathogens of ectothermic vertebrates. Springer, New York

Earl JE, Gray MJ (2014) Introduction of ranavirus to isolated wood frog population could cause local extinction. EcoHealth 11:581-592

Evira (2013) Risk assessment of new and emerging systemic iridoviral diseases for European fish and aquatic ecosystems (RANA). http://www.evira.fi/portal/en/about+evira/about+us/ operation+areas/scientific+research/projects/previous/risk+assessment+of+new+and+emergin $\mathrm{g}+$ systemic+iridoviral+diseases+for+european+fish+and+aquatic+ecosystems++rana+/. Accessed 21 May 2014

Federico P, Gross LJ, Lenhart S et al (2013) Optimal control in individual-based models: implications from aggregated methods. Am Nat 181:64-77

Fenichel EP, Horan RD, Hickling GJ (2010) Management of infectious wildlife diseases: bridging conventional and bioeconomic approaches. Ecol Appl 20:903-914

Forzán MJ, Wood J (2013) Low detection of ranavirus DNA in wild postmetamorphic green frogs, Rana (Lithobates) clamitans, despite previous or concurrent tadpole mortality. Journal of Wildlife Diseases 49:879-886 
Gahl MK, Calhoun AJK (2008) Landscape setting and risk of ranavirus mortality events. Biol Conserv 141:2679-2689

Gotelli NJ, Ellison AM (2004) A primer of ecological statistics. Sinauer, Sunderland

Gray MJ, Miller DL (2013) The rise of ranavirus: an emerging pathogen threatens ectothermic vertebrates. Wildl Prof 7:51-55

Gray MJ, Miller DL, Hoverman JT (2009) Ecology and pathology of amphibian ranaviruses. Dis Aquat Organ 87:243-266

Gray MJ, Miller DL, Hoverman JT (2012) Reliability of non-lethal surveillance methods for detecting ranavirus infection. Dis Aquat Organ 99:1-6

Greer AL, Collins JP (2008) Habitat fragmentation as a result of biotic and abiotic factors controls pathogen transmission throughout a host population. J Anim Ecol 77:364-369

Grimm V, Railsback SF (2005) Individual-based modeling and ecology. Princeton University Press, Princeton

Grimm V, Railsback SF (2012) Pattern-oriented modelling: a "mulit-scope" for predictive systems ecology. Philos Trans R Soc Lond B Biol Sci 367:298-310

Grimm V, Revilla E, Berger U et al (2005) Pattern-oriented modeling of agent-based complex systems: lessons from ecology. Science 310:987-991

Grimm V, Augusiak J, Focks A et al (2014) Towards better modelling and decision support: documenting model development, testing, and analysis using TRACE. Ecol Model 280:129-139

Haislip NA, Gray MJ, Hoverman JT et al (2011) Development and disease: how susceptibility to an emerging pathogen changes through anuran development. PLoS One 6:e22307

Hamed MK, Gray MJ, Miller DL (2013) First report of ranavirus in plethodontid salamanders from the Mount Roger's National Recreation Area, Virginia. Herpetological Review 44:455-457

Hanski I (1999) Metapopulation ecology. Oxford University Press, New York

Harp EM, Petranka JW (2006) Ranavirus in wood frogs (Rana sylvatica): potential sources of transmission within and between ponds. J Wildl Dis 42:307-318

Harper EB, Rittenhouse TG, Semlitsch RD (2008) Demographic consequences of terrestrial habitat loss for pool-breeding amphibians: predicting extinction risks associated with inadequate size of buffer zones. Conserv Biol 22:1205-1215

Hastings A (1997) Population biology: concepts and models. Springer, New York

Helmer O (1967) Analysis of the future: the Delphi method. RAND, Santa Monica

Hess G (1996) Disease in metapopulation models: implications for conservation. Ecology 77: $1617-1632$

Hethcote HW (2000) The mathematics of infectious disease. SIAM Rev 42:599-653

Hosmer DW, Lemeshow S, May S (2008) Applied survival analysis: regression modeling of time to event data. Wiley, Hoboken

Hoverman JT, Gray MJ, Haislip NA et al (2011) Phylogeny, life history, and ecology contribute to differences in amphibian susceptibility to ranaviruses. Ecohealth 8:301-319

Hoverman JT, Gray MJ, Miller DL et al (2012) Widespread occurrence of ranavirus in pond-breeding amphibian populations. Ecohealth 9:36-48

Jager KJ, Van Dijk C, Zoccali C et al (2008) The analysis of survival data: the Kaplan-Meier method. Kidney Int 74:560-565

Jancovich JK, Qin Q, Zhang Q-Y, Chinchar VG (2015a) Ranavirus replication: molecular, cellular, and immunological events. In: Gray MJ, Chinchar VG (eds) Ranaviruses: lethal pathogens of ectothermic vertebrates. Springer, New York

Jancovich JK, Steckler N, Waltzek TB (2015b) Ranavirus taxonomy and phylogeny. In: Gray MJ, Chinchar VG (eds) Ranaviruses: lethal pathogens of ectothermic vertebrates. Springer, New York

Johnson AJ, Pessier AP, Jacobson ER (2007) Experimental transmission and induction of ranaviral disease in western ornate box turtles (Terrapene ornata ornata) and red-eared sliders (Trachemys scripta elegans). Vet Pathol 44:285-297

Keesing F, Holt RD, Ostfeld RS (2006) Effects of species diversity on disease risk. Ecol Lett 9:485-498 
Kerby JL, Hart AJ, Storfer A (2011) Combined effects of virus, pesticide, and predator cue on the larval tiger salamander (Ambystoma tigrinum). Ecohealth 8:46-54

Kolby JE, Smith KM, Berger L et al (2014) First evidence of amphibian chytrid fungus (Batrachochytrium dendrobatidis) and ranavirus in Hong Kong amphibian trade. PLoS One 9:e90750

Lélu M, Langlais M, Poulle M et al (2013) When should a trophically and vertically transmitted parasite manipulate its intermediate host? The case of Toxoplasma gondii. Proc Biol Sci 280:20131143

Lenhart S, Workman JT (2007) Optimal control applied to biological models. Chapman \& Hall/ CRC, Boca Raton

Lloyd-Smith JO, Cross PC, Briggs CJ et al (2005) Should we expect population thresholds for wildlife disease? Trends Ecol Evol 20:511-519

Marsh DM, Trenham PC (2001) Metapopulation dynamics and amphibian conservation. Conserv Biol 15:40-49

Martín Andrés A, Silva Mato A, Tapia García JM et al (2004) Comparing the asymptotic power of exact tests in $2 \times 2$ tables. Comput Stat Data Anal 47:745-756

McCallum H, Barlow N, Hone J (2001) How should pathogen transmission be modeled. Trends Ecol Evol 16:295-300

Mideo N, Barclay VC, Chan BHK et al (2008) Understanding and predicting strain-specific patterns of pathogenesis in the rodent malaria, Plasmodium chabaudi. Am Nat 172:E214-E238

Mideo N, Savill NJ, Chadwick W et al (2011) Causes of variation in malaria infection dynamics: insights from theory and data. Am Nat 178:174-188

Miller DL, Gray MJ, Storfer A (2011) Ecopathology of ranaviruses infecting amphibians. Viruses 3:2351-2373

Miller DL, Pessier AP, Hick P, Whittington RJ (2015) Comparative pathology of ranaviruses and diagnostic techniques. In: Gray MJ, Chinchar VG (eds) Ranaviruses: lethal pathogens of ectothermic vertebrates. Springer, New York

Nazir J, Spengler M, Marschang RE (2012) Environmental persistence of amphibian and reptilian ranaviruses. Dis Aquat Organ 98:177-184

OIE (2014) Aquatic Animal Health Code (online access). Office International des Epizooties, Paris. http://www.oie.int/international-standard-setting/aquatic-code/. Accessed 21 May 2014

Otto SP, Day T (2007) A biologist's guide to mathematical modeling in ecology and evolution. Princeton University Press, Princeton

Price, SJ, Garner TWJ, Nichols RA, et al. (2014) Collapse of amphibian communities due to an introduced Ranavirus. Curr Biol 24:2586-2591. http://www.cell.com/current-biology/pdfExtended/S0960-9822(14)01149-X

Railsback SF, Grimm V (2011) Agent-based and individual-based modeling: a practical introduction. Princeton University Press, Princeton

Robert J, George E, De Jesús Andino F et al (2011) Waterborne infectivity of the Ranavirus frog virus 3 in Xenopus laevis. Virology 417:410-417

Rödder D, Kielgast J, Bielby J et al (2009) Global amphibian extinction risk assessment for the panzootic chytrid fungus. Diversity 1:52-66

Schloegel LM, Ferreira CM, James TY et al (2010) The North American bullfrog as a reservoir for the spread of Batrachochytrium dendrobatidis in Brazil. Anim Conserv 14:53-61

Smith MA, Green DM (2005) Dispersal and the metapopulation paradigm in amphibian ecology and conservation: are all amphibian populations metapopulations? Ecography 28:110-128

Smith KF, Behrens M, Schoegel LM et al (2009) Reducing the risk of wildlife trade. Science 324:594-595

Smith SA, Seigel RA, Driscoll CP et al (2014) Detecting the extent of mortality events from ranavirus in amphibians of the Northeastern U.S. http://rcngrants.org/sites/default/files/original_ proposals/RCN\%202012(1)\%20Ranavirus\%20in\%20amphibians.pdf. Accessed 21 May 2014

St-Amour V, Lesbarrères D (2007) Detecting Ranavirus in toe clips: an alternative to lethal sampling methods. Conserv Genet 8:1247-1250

Storfer A, Alfaro ME, Ridenhour BJ et al (2007) Phylogenetic concordance analysis shows an emerging pathogen is novel and endemic. Ecol Lett 10:1075-1083 
Sutton WB, Gray MJ, Hoverman JT et al (2014) Trends in ranavirus prevalence among plethodontid salamanders in the Great Smoky Mountains National Park. EcoHealth DOI:10.1007/ s10393-014-0994-z

Teacher AGF, Cunningham AA, Garner TWJ (2010) Assessing the long-term impact of Ranavirus infection in wild common frog populations. Anim Conserv 13:514-522

Thoesen JC (1994) Blue book: suggested procedures for the detection and identification of certain finfish and shellfish pathogens. Version 1. American Fisheries Society, Bethesda

Thomson DL, Cooch EG, Conroy MJ (2009) Modeling demographic processes in marked populations, Environmental and ecological statistics. Springer, New York

Todd-Thompson M (2010) Seasonality, variation in species prevalence, and localized disease for ranavirus in cades cove (Great Smoky Mountains National Park) amphibians. M.S., University of Tennessee. http://trace.tennessee.edu/utk_gradthes/665/. Accessed 21 May 2014

Vose D (2000) Risk analysis—a quantitative guide, 2nd edn. Wiley, Chichester

Waltzek TB, Miller DL, Gray MJ et al (2014) New disease records for hatchery-reared sturgeon. I. Expansion of Frog Virus 3 into Scaphirhynchus albus. Diseases of Aquatic Organisms 111:219-227

Wells KD (2007) The ecology and behavior of amphibians. University of Chicago Press, Chicago

Wiegand T, Jeltsch F, Hanski I et al (2003) Using pattern-oriented modeling for revealing hidden information: a key for reconciling ecological theory and application. Oikos 100:209-222

Williams BK, Nichols JD, Conroy MJ (2002) Analysis and management of animal populations. Academic, San Diego

Wilson EB (1927) Probable inference, the law of succession, and statistical inference. J Am Stat Assoc 22:209-212

Wobeser GA (2006) Essentials of disease in wild animals. Blackwell, Ames

Woodhams DC, Alford RA, Briggs CJ et al (2008) Life-history trade-offs influence disease in changing climates: strategies of an amphibian pathogen. Ecology 89:1627-1639

Woodhams DC, Bosch J, Briggs CJ et al (2011) Mitigating amphibian disease: strategies to maintain wild populations and control chytridiomycosis. Front Zool 8:8

Zuur AF, Savaliev AA, Ieno EN (2012) Zero inflated models and generalized linear mixed models with R. Highland Statistics, Newburgh 


\section{Index}

A

Accelerated failure time (AFT) models, 222

Adaptive immune responses antibody responses, 156-157 immunological memory, 158 nonclassical MHC-restricted cells, 158-159

T cell responses, 157

ADRV. See Andrias davidianus ranavirus (ADRV)

Agent-based models (ABMs), 226

Ambystoma tigrinum virus (ATV) amphibians, 25, 62, 64

coevolutionary history, 91

fish, 62, 64

genomic organization, 108

ICTV recognization, 61

interclass transmission, 43

$\mathrm{KO}$ and KI mutants, 124

phylogenetic analysis, 61-63

Andrias davidianus ranavirus (ADRV)

amphibians, 62, 64

phylogenetic analysis, 61-63

Antisense morpholino oligonucleotides (asMO), 113, 115, 121-123

Antiviral immune responses

IFN, ectothermic vertebrates

cytosolic DNA sensors, 152

Mx proteins, 153-154

RIG-I-like receptors, 152

TLRs, 152

type I IFN, 152-153

type II IFN, 152, 153

type III IFN, 152, 153

immune parameter, 160 ranavirus infections

EHNV, 154

ESV, 154

IFITM1 functions, 155

IPNV, 154

LCDV, 154

RGV infections, 154-155

RSIV, 154

SAV, 154

VHSV, 154

VNNV, 154

$X$. laevis type I IFN, 155-156

ATV. See Ambystoma tigrinum virus (ATV)

B

$3 \beta$-Hydroxysteroid dehydrogenase ( $\beta \mathrm{HSD}$ ), $122,124,127-128,162$

Bohle iridovirus (BIV) amphibians, 26, 62, 64

fish, 62,64

ICTV recognization, 61

interclass transmission, 43

phylogenetic analysis, 61-63

reptiles, 62, 64

C

Capture-mark reencounter (CMR) model, 212, 222-223

Chinese giant salamander iridovirus. See Andrias davidianus ranavirus (ADRV)

Chi-square tests, 217, 218

Cod ranavirus (CoIV), 36 
Common midwife toad virus (CMTV)

amphibians, 26-27, 62, 64

genomic organization, 108

phylogenetic analysis, 61-63

Cox Proportional Hazard (Cox PH) model, 221

Critical control points (CCP), 233, 234

Cytopathic effect (CPE), 191

\section{D}

Danish Atlantic cod, 36

Data analysis

AFT models, 222

Chi-square tests, 217, 218

CMR model, 222-223

confidence intervals, 216-217

contingency table, 217

Cox PH model, 221-222

Kaplan-Meier (K-M) function, 220-221

logistic regression, 218-219

Mantel-Haenszel test, 221

viral titers, 219-220

DNA cytosine methyltransferase (DMTase),

$$
112,162-163
$$

DNA sequence analysis, 62, 66

Dot plot analysis, 62, 64, 67, 108

dUTP pyrophosphatase (dUTPase), 117, 125, $128,130,162$

Dynamic models

evaludation, 229-230

IBMs, 226-227

modeling disease intervention strategy, 228-229

parameterize models, 229

POM, 227

population matrix models, $227-228$

SI/SIR models, 224-226

\section{$\mathbf{E}$}

Electron microscopy (EM), 197

Epizootic hematopoietic necrosis virus (EHNV) amphibians, 62, 64

epidemics, 79

fish, 28-29, 62, 64

ICTV recognization, 61

phylogenetic analysis, 61-63

polyclonal antisera, 194

typical cytopathic effect, 191

Essential for replication and viability (ERV1), 125,128
European catfish virus (ECV)

fish, 29-30

ICTV recognization, 61

polyclonal antisera, 194

European sheatfish virus (ESV), 29, 30, 154

F

Frog virus 3 (FV3)

amphibians, 62, 64

epidemics, 81-82

fish, 62, 64

genomic organization, 108

GIV, 108

ICTV recognization, 61

infecting amphibians, 23-25

infecting fish, 31,35

interclass transmission, 43

KO and KI mutants, 124

molecular and cellular events, 2

phylogenetic analysis, 61-63

replication strategy, 1-2

reptiles, 62,64

translational research, 2

G

Global Ranavirus Consortium (GRC), 4

Granoff, Allan, 1

Grouper iridovirus (GIV)

fish, 27, 36, 62, 64

genomic sequence, 108

phylogenetic analysis, 61-63

whole genome dot plot analysis, 67

\section{H}

Herpes simplex virus 1 (HSV1), 117

Host antiviral immunity

BHSD, 162

DMTase, 162

dUTPase, 162

RNAse III-like proteins, 161-162

vCARD, 162

vIF-2 $\alpha$ blocks phosphorylation, 159, 161

vTNFR, 162

\section{I}

Immune evasion

adaptive immune responses antibody responses, 156-157

immunological memory, 158 
nonclassical MHC-restricted cells, 158-159

$\mathrm{T}$ cell responses, 157

antiviral immune responses (see Antiviral immune responses)

innate immune responses

antimicrobial peptide responses, 142

anuran amphibians, 143-145

ranavirus-induced pathogenicity and mortality, 146-147

teleost fish, 145-146

urodel amphibians, 145

macrophage-lineage cells

amphibian vectors, $148-150$

FV3 infection, 147-148

ranavirus infections, 150-152

reservoirs and ranavirus reactivation, 150,151

Immunohistochemistry (IHC), 194-196

Import risk analysis (IRA)

consequence assessment, 234

definition, 230-231

flow diagrams, 231-233

risk estimation, 234-235

risk management and communication, 235

routes of introduction, 232-234

Individuals-based models (IBMs), 226-227

Infectious pancreatic necrosis virus (IPNV), 154

Innate immune responses

antimicrobial peptide responses, 142

anuran amphibians, 143-145

ranavirus-induced pathogenicity and mortality, 146-147

teleost fish, 145-146

urodel amphibians, 145

In situ hybridization (ISH), 195, 197

International Committee on Taxonomy of Viruses (ICTV), 27, 59

Invertebrate iridovirus 1 (IIV1), 1

\section{$\mathbf{K}$}

Kaplan-Meier (K-M) function, 220-221

Knock down (KD) strategies, 121-123

Knock-in (KI) mutants, 124

Knock out (KO) mutants, 123-124, 146, 163

$\mathbf{L}$

Largemouth bass virus (LMBV)

cutaneous mucus, 85

die-offs, 75,79

epidemics, 81 fish, 27

genomic sequence, 67

mortality, 146

water transmission, 85

Lymphocystis disease virus (LCDV), 1, 2, 107,154

M

Macrophage-lineage cells

amphibian vectors, $148-150$

FV3 infection, 147-148

ranavirus infections, 150-152

reservoirs and ranavirus reactivation, 150,151

Mantel-Haenszel test, 220, 221

Myxovirus resistance (Mx) protein, 153-154

$\mathbf{N}$

Nucleocytoplasmic large DNA viruses (NCLDV)

Ascoviridae, 59-60

Asfarviridae, 59-60

classification, 59

comparative analysis, 60

genome size, 59-60

Iridoviridae, 60

Mimiviridae, 59-60

Phycodnaviridae, 59-60

Poxviridae, 59-60

sequence analysis, 60-61

O

Open reading frames (ORFs), 106, 108

$\mathbf{P}$

Pattern-oriented modeling (POM), 227, 229

Pike-perch iridovirus (PPIV), 36, 43, 62, 81, 88

Q

Quantitative real-time PCR (qPCR), 188-189

$\mathbf{R}$

Ranaviral disease

diagnostic testing antigen-capture ELISA, 190

bioassay/experimental transmission trial, 193 
Ranaviral disease (cont.)

conventional PCR, 188

cytology, 194

detection antibodies, 192-193

electron microscopy, 197

IHC, 194-196

OIE reference laboratory, 180-181

qPCR, 188-189

ranavirus species and strains, $189-190$

sample collection protocols, 184-186

sample types and limitations, 183, 184

in situ hybridization, 195, 197

sterile collection techniques, 184-185

with study goal, 181-183

test validation and efficiency, 197-198

virus isolation, 190-192

field and clinical findings, 172-173

gross pathology

amphibians, 174-175

fish, 175-176

lesions, 173-174

reptiles, 177

histopathology, 178-180, 193-194

subclinical infection, 179-180

treatment and vaccine development, 198-199

Ranavirus (RV)

anthropogenic stressors, 83-84

design and analysis of (see Study design)

diagnosis and pathology (see Ranaviral disease)

ectothermic vertebrate classes, 10, 12

epidemics

detection biases, 77

seasonal introductions and incidence, $77-78$

stage-specific susceptibility, 79, 80

temperatures, 79-82

epidemiology

in amphibians, 72-74

in fishes, 74-75

in reptiles, 75-76

evolution, 4, 91-93

global distribution, 10, 11

Granoff, Allan, 1

host immunity (see Host antiviral immunity) immune evasion (see Immune evasion) infecting amphibians

ATV, 25

BIV, 26

CMTV, 26-27

distribution cases, 13, 22

ectothermic vertebrate classes, 12, 13

epizootic die-offs, 13

FV3, 23-25

global distribution, 11, 14-21 infecting fish

BIV, 35-36

CoIV, 36

ECV, 29-30

EHNV, 28-29

FV3, 31, 35

GIV, 32-34, 36

LMBV, 27

PPIV, 36

SCRV, 30-34

SERV, 36

SGIV, 32-34, 36

infecting reptiles

in chelonians, 38-41

reptile cases, $37-40$

in squamates, $41-42$

persistence of, 88-90

predators and natural stressors, 83

replication (see Replication)

risk of extinction, 93-94

selection and coevolution, 90-91

susceptibility, 87-88

taxonomy (see Taxonomy)

transmission

direct transmission, 86

fomites, 84

indirect transmission, 86

interclass transmission, 43-44, 86

mosquito transmission, 85

water-borne transmission, 84,85

undisturbed sites, 44-46

viral countermeasures, 4

Ranaviruses also contain homologs of Tumor

Necrosis Factor (TNF) receptor

(vTNFR), 162

Red seabream iridovirus (RSIV), $107,154,157$

Replication

antiviral immunity, 118-119

genomes

coding capacity, 107

coding regions, 109

complete genomic sequence information permitted analysis, 107-108

features, 106, 107

FV3, 106-107

gene products, 108, 109

genetic composition, 107

genomic organization, 108

hosts, 107

inter-and intragenic variation, 109

microsatellites, 109

ORFs, 106, 107

palindromes, 109 
percentage of guanine and cytosine

$(\mathrm{G}+\mathrm{C}), 106,107$

phylogenetic analysis, 106, 107

repeat and variable regions, 109

size, 106-108

host and virus determination, 117-118

strategy

cytoplasmic events, 112

nuclear events, $111-112$

viral entry, 110-111

virus assembly sites, 112-115

taxonomy, 106, 107

viral gene function

asMOs, 121-123

assessment of, 125-127

$\beta$ HSD, 127-128

biochemical and genetic approaches, 119-121

conditionally lethal mutants, $124-125$

dUTPase, 128

ERV1, 128

knock out mutants, 123-124

LITAF, 129

recombinant SGIV-and I,9 Proteins, 130-131

RGD motif-containing proteins, 129-130

RGV 50L, 128-129

RNA interference, $121-123$

vIF-2 $\alpha, 125-127$

virus infection

apoptosis, 115

host shut-off and selective expression, 116

necrosis, 116

parapoptosis, 115-116

Restriction endonuclease fragment length polymorphism (RFLP), 62, 66

RNA interference (RNAi), 121-123

\section{$\mathbf{S}$}

Salmonid alpha virus (SAV), 154

Santee-Cooper ranavirus (SCRV)

fish, 30-34

ICTV recognization, 61

Short-finned eel ranavirus (SERV), 36, 62, 80,88

Singapore grouper iridovirus (SGIV), 27, 36,

Study design $61,67,75,108,116,195,198$

data analysis

AFT models, 222

Chi-square tests, 217, 218

CMR model, 222-223

confidence intervals, 216-217

contingency table, 217
Cox PH model, 221-222

Kaplan-Meier (K-M) function, 220-221

logistic regression, 218-219

Mantel-Haenszel test, 221

viral titers, 219-220

dynamic models

evaludation, 229-230

IBMs, 226-227

modeling disease intervention strategies, 228-229

parameterize models, 229

POM, 227

population matrix models, 227-228

SI/SIR models, 224-226

import risk analysis

consequence assessment, 234

definition, 230-231

flow diagrams, 231-233

risk estimation, 234-235

risk management and communication, 235

routes of introduction, 232-234

laboratory and mesocosm studies, 214

ranavirus surveillance

interpreting infection data, 211-212

planning, 213

random sampling, 213-214

required sample size, 214-216

Susceptible-infected (SI) model, 224-226

Susceptible-infected-recovered (SIR) models, 224-226

$\mathbf{T}$

Taxonomy

ADRV

amphibians, 62, 64

phylogenetic analysis, 61-63

ATV

amphibians, 62, 64

fish, 62,64

ICTV recognization, 61

phylogenetic analysis, 61-63

BIV

amphibians, 62, 64

fish, 62, 64

ICTV recognization, 61

phylogenetic analysis, 61-63

reptiles, 62,64

CMTV

amphibians, 62, 64

phylogenetic analysis, 61-63

cold-blooded vertebrate hosts, 61

distribution, 10-11

DNA sequence analysis, 62 


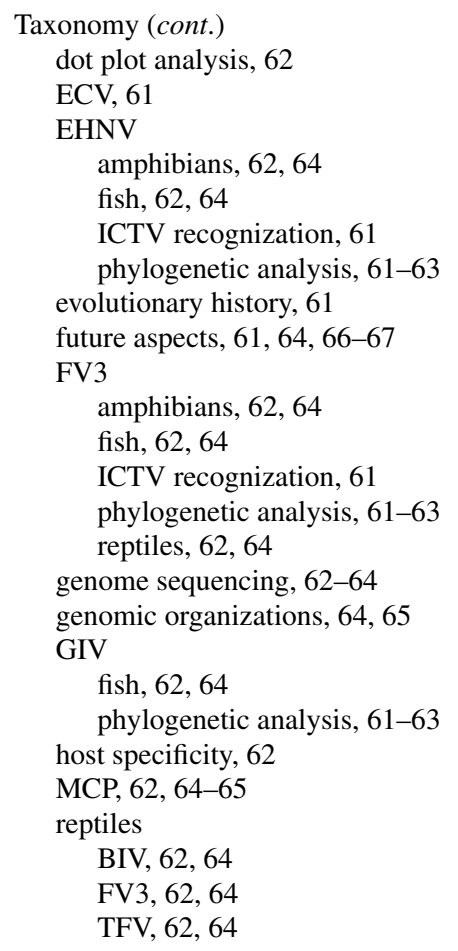

RFLP profiles, 62

SCRV

fish, 62, 64

ICTV recognization, 61

phylogenetic analysis, 62, 64-65

SGIV, 61-63

TFV

amphibians, 62, 64

fish, 62, 64

phylogenetic analysis, 61-63

reptiles, 62,64

wide host range, 61

Toll-like receptors (TLRs), 152

Transmission electron microscopic (TEM) analysis, 114

V

Vaccinia virus (VACV), 117, 124,

125,127

Viral nervous necrosis virus

(VNNV), 154

$\mathbf{X}$

Xenopus laevis type I interferon

(XIIFN), 119 